\title{
THE IMPACT OF WASTE LOADING ON VISCOSITY IN THE FRIT 418 - SB3 SYSTEM
}

D.K. Peeler

T.B. Edwards

R.J. Workman

I.A. Reamer

August 2004

Immobilization Technology Section

Savannah River National Laboratory

Savannah River National Laboratory

Aiken, SC 29808

Prepared for the U.S. Department of Energy Under Contract Number DEAC09-96SR18500

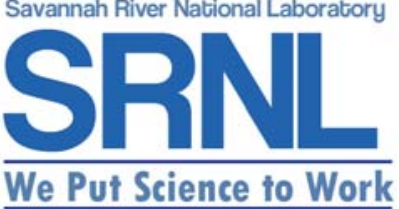


This document was prepared in conjunction with work accomplished under Contract No. DE-AC09-96SR18500 with the U. S. Department of Energy.

\section{DISCLAIMER}

This report was prepared as an account of work sponsored by an agency of the United States Government. Neither the United States Government nor any agency thereof, nor any of their employees, makes any warranty, express or implied, or assumes any legal liability or responsibility for the accuracy, completeness, or usefulness of any information, apparatus, product or process disclosed, or represents that its use would not infringe privately owned rights. Reference herein to any specific commercial product, process or service by trade name, trademark, manufacturer, or otherwise does not necessarily constitute or imply its endorsement, recommendation, or favoring by the United States Government or any agency thereof. The views and opinions of authors expressed herein do not necessarily state or reflect those of the United States Government or any agency thereof.

This report has been reproduced directly from the best available copy.

Available for sale to the public, in paper, from: U.S. Department of Commerce, National Technical Information Service, 5285 Port Royal Road, Springfield, VA 22161, phone: (800) 553-6847, fax: (703) 605-6900

email: orders@ntis.fedworld.gov

online ordering: http://www.ntis.gov/help/index.asp

Available electronically at http://www.osti.gov/bridge

Available for a processing fee to U.S. Department of Energy and its contractors, in paper, from: U.S. Department of Energy, Office of Scientific and Technical Information, P.O. Box 62, Oak Ridge, TN 37831-0062,

phone: (865)576-8401,

fax: (865)576-5728

email: $\underline{\text { reports@ adonis.osti.gov }}$ 
Key Words: viscosity, DWPF, PCT, durability

Retention: Permanent

\section{THE IMPACT OF WASTE LOADING ON VISCOSITY IN THE FRIT 418 - SB3 SYSTEM}

D.K. Peeler

T.B. Edwards

R.J. Workman

I.A. Reamer

August 2004

Immobilization Technology Section

Savannah River National Laboratory Savannah River National Laboratory Aiken, SC 29808 
This page was intentionally left blank 


\section{EXECUTIVE SUMMARY}

In this report, data are provided to gain insight into the potential impact of a lower viscosity glass on melter stability (i.e., pressure spikes, cold cap behavior) and/or pour stream stability. High temperature viscosity data are generated for the Frit 418 - SB3 system as a function of waste loading (from 30 to 45\%) and compared to similar data for other systems that have been (or are currently being) processed through the Defense Waste Processing Facility (DWPF) melter. The data are presented in various formats to potentially align the viscosity data with physical observations at various points in the melter system or critical DWPF processing unit operations. The expectation is that the data will provide adequate insight into the vitrification parameters which might evolve into working solutions as DWPF strives to maximize waste throughput.

The data indicates that as waste loading increases in the Frit 418 - SB3 system the viscosity decreases. The $\eta_{1150^{\circ} \mathrm{C}}$ values range from 42.33 to 24.77 Poise at $30 \%$ and $45 \%$ waste loading, respectively. This trend is consistent with Product Composition Control System (PCCS) model predictions. In addition, as temperatures decrease, the viscosity increases (non-linearly) for a fixed waste loading. The non-linear relation between viscosity and temperature observed in the Frit $418-$ SB3 system is typical of inorganic glasses. The data presented demonstrated that for a fixed change in temperature $(\Delta \mathrm{T})$, the change in viscosity $(\Delta \eta)$ becomes more dramatic in the lower temperature range. Although the trends in the viscosity versus waste loading data are relatively consistent with PCCS model predictions, a potentially significant difference is observed when magnitudes were compared. For example, the PCCS predictions for VIS-01 (30\% waste loading) are between $\sim 14-18$ Poise higher than the Fulcher fit predictions based on measured viscosity data. This apparent bias in the PCCS model decreases as waste loadings increase or viscosity decrease to the point of being within experimental error (or at least of no practical concern) at $45 \%$ waste loading.

The report attempts to provide insight into a physical interpretation of the data from a DWPF perspective. The theories presented are certainly not an all inclusive list and the order in which they are presented does not imply a ranking, probability, or likelihood that the proposed theory is even plausible. The intent of this discussion is to provide a forum in which the viscosity data can be discussed in relation to possible mechanisms which could potentially led to a workable solution as higher overall attainment is strived for during processing of the current or future sludge batches. 


\section{TABLE OF CONTENTS}

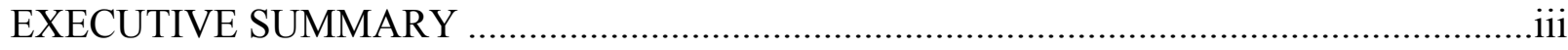

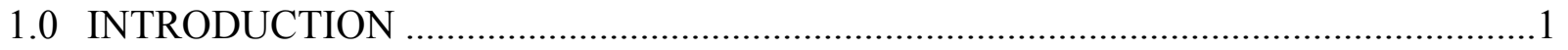

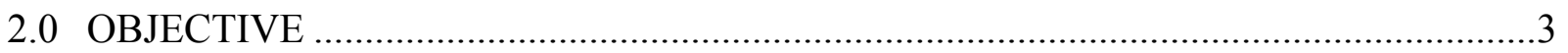

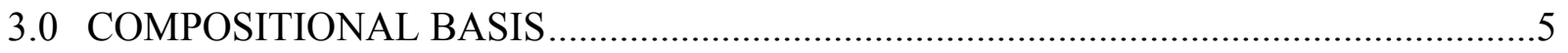

4.0 MAR ASSESSMENTS AND TARGET COMPOSITIONS ..........................................

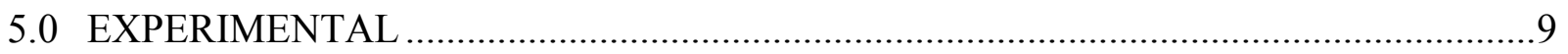

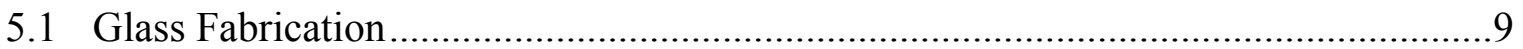

5.2 Chemical Composition Analysis ..................................................................

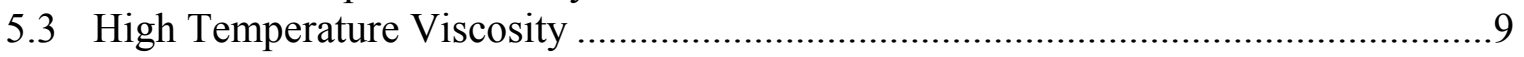

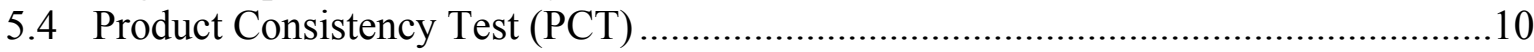

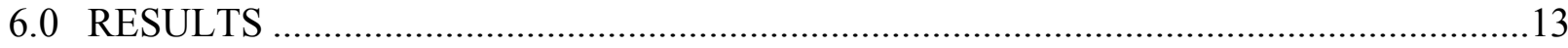

6.1 A Statistical Review of the Chemical Composition Measurements............................13

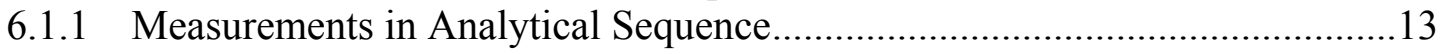

6.1.2 Batch 1 and Uranium Standard Results ..................................................... 14

6.1.3 Composition Measurements by Glass Number ...........................................15

6.1.4 Measured versus Targeted Compositions......................................................15

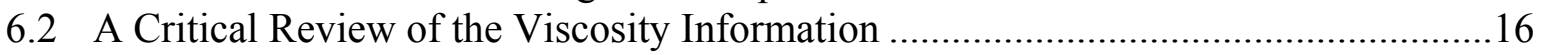

6.2.1 DWPF Start-Up Frit (Standard) Results...................................................16

6.2.2 Viscosity Versus Temperature Data for the VIS Glasses.............................. 17

6.2.3 Fulcher Fits and $\eta_{1150^{\circ} \mathrm{C}}$ Values for Each VIS Glass.......................................18

6.2.4 Model Predictions Versus Experimental Data .................................................24

6.2.5 Physical Interpretation of the Viscosity Versus Temperature Data ................28

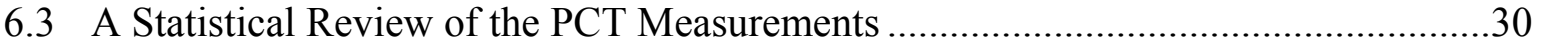

6.3.1 Measurements in Analytical Sequence..........................................................

6.3.2 Results for the Samples of the Multi-Element Solution Standard...................31

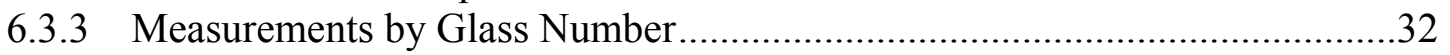

6.3.4 Quenched versus Centerline Canister Cooled PCTs ..........................................32

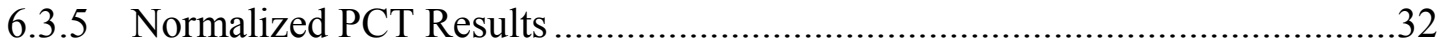

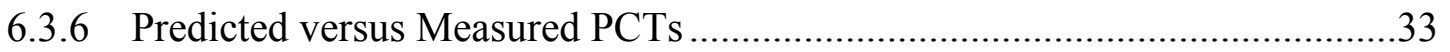

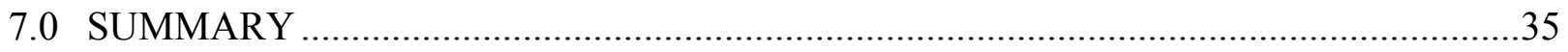

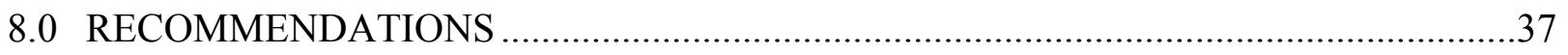

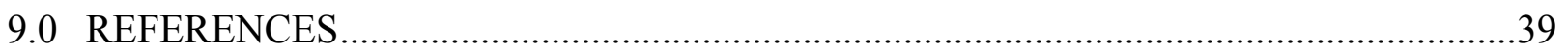

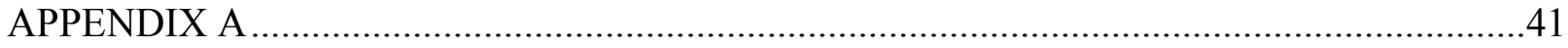

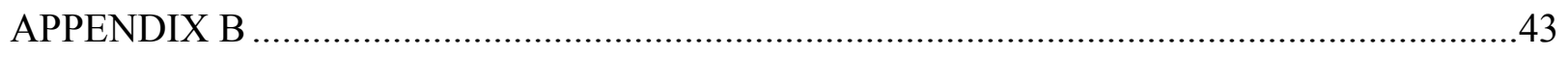

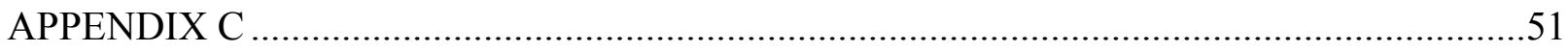

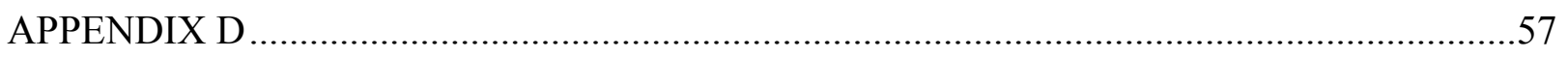

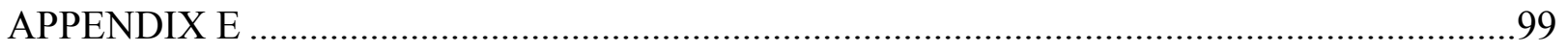

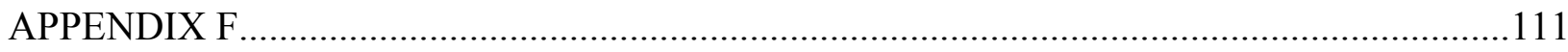




\section{LIST OF FIGURES}

Figure 6-1. Viscosity Versus Temperature for the VIS Glasses..................................................... 20

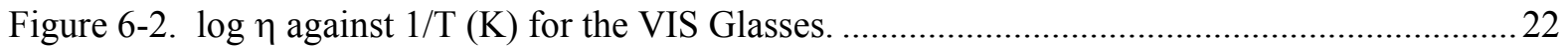

Figure 6-3. $\log \eta$ against 1/T (K) for Various Glass Systems of Interest........................................ 23

\section{LIST OF TABLES}

Table 3-1. Projected Compositions (in wt $\%$ ) for Three SB3 Cases. .................................................... 5

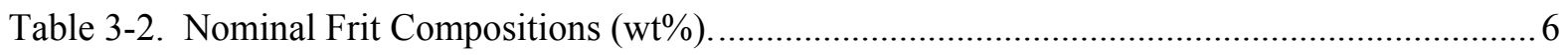

Table 4-1. Target Compositions and PCCS $\eta_{1150^{\circ} \mathrm{C}}$ Predictions for VIS Glasses................................ 8

Table 6-1. DWPF Start-Up Frit (Standard) Compared to Round Robin Results. ............................. 16

Table 6-2. Viscosity Versus Temperature Data for the VIS Glasses. ................................................ 17

Table 6-3. Fit Parameters and $\eta_{1150^{\circ} \mathrm{C}}$ Values for the VIS Glasses. ................................................ 18

Table 6-4. Predicted Viscosities at Various Temperatures Using Fulcher Fit. .................................. 19

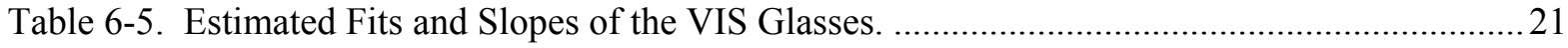

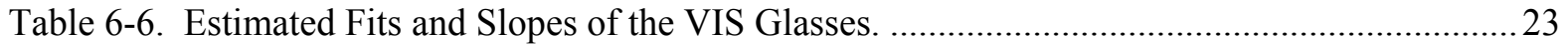

Table 6-7. "Measured $\eta_{1150}$ " (based on Fulcher fit of measured data) Versus PCCS Predictions. ..... 24

Table 6-8. $\eta_{1150^{\circ} \mathrm{C}}$ Predicted Based on Fulcher Fit and PCCS Models for Various Flowsheets. .......... 27

Table 6-9. Results from Samples of the Multi-Element Solution Standard. ........................................ 31

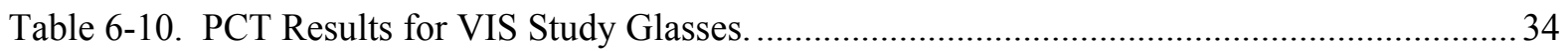




\section{LIST OF ACRONYMS}

\begin{tabular}{|c|c|}
\hline ADT & Alternative Durability Glasses \\
\hline ANOVA & analysis of variance \\
\hline ARM & Approved Reference Material \\
\hline $\mathrm{CBU}$ & Closure Business Unit \\
\hline $\mathrm{ccc}$ & canister centerline cooled \\
\hline DOE & Department of Energy \\
\hline DWPF & Defense Waste Processing Facility \\
\hline$\Delta \mathrm{G}_{\mathrm{P}}$ & preliminary glass dissolution estimator \\
\hline EA & Environmental Assessment \\
\hline $\mathrm{ICP}-\mathrm{AES}$ & inductively coupled plasma - atomic emission spectroscopy \\
\hline $\mathrm{LM}$ & lithium metaborate \\
\hline MAR & Measurement Acceptability Region \\
\hline MRF & melt rate furnace \\
\hline NIST & National Institute of Standards and Technology \\
\hline $\mathrm{NL}[\mathrm{B}]$ & normalized boron release (in $\mathrm{g} / \mathrm{L}$ ) \\
\hline PCCS & Product Composition Control System \\
\hline PCT & Product Consistency Test \\
\hline $\mathrm{PF}$ & peroxide fusion \\
\hline QA & quality assurance \\
\hline SB & sludge batch \\
\hline SME & Slurry Mix Evaporator \\
\hline SMRF & slurry fed melt rate furnace \\
\hline SRNL & Savannah River National Laboratory \\
\hline SRNL-ML & Savannah River National Laboratory - Mobile Laboratory \\
\hline $\mathrm{T}_{\mathrm{L}}$ & liquidus temperature \\
\hline $\mathrm{U}_{\text {std }}$ & uranium standard \\
\hline$\eta_{1150^{\circ} \mathrm{C}}$ & viscosity at $1150^{\circ} \mathrm{C}$ \\
\hline VIS & VIScosity \\
\hline WL & waste loading \\
\hline WSRC & Westinghouse Savannah River Company \\
\hline
\end{tabular}




\subsection{INTRODUCTION}

In support of accelerated mission goals, glass formulation efforts have been focused on melt rate and waste loading (WL) which ultimately dictate waste throughput for the Defense Waste Processing Facility (DWPF). With respect to melt rate, the general trend for improvement has been to enhance the total alkali concentration in the glass system by increasing the alkali concentration in the frit (Lambert et al. 2001), utilizing (or targeting) a less washed sludge, or using a combination of the two. Previous assessments have indicated that as higher alkali systems are pursued, a transition can occur in which predictions of durability and/or low viscosity begin limiting upper waste loadings rather than predictions of liquidus temperature $\left(T_{L}\right)($ Peeler and Edwards 2002).

The DWPF began processing Sludge Batch 2 (SB2) with Frit 320 in March 2003 (beginning with Slurry Mix Evaporator (SME) Batch 227). At the time Frit 320 was implemented, other operational parameters also changed (e.g., Melter \#2 was installed). In May of 2003 (SME Batch 234), DWPF began targeting higher WLs (between 35 - 40\%) with subsequent operations experiencing "negative" processing or operational issues. These included large pressure spikes in the melter resulting in an off-gas system switch over as well as frequent plugging of the pour spout and bellows liner, observations regarding the instability of the pour stream and "excessive" amounts of material within the pour spout. In an effort to avoid a negative impact on overall attainment, feed rates were lowered which resulted in 40 - 45 hour canister fill times unacceptable in terms of the accelerated mission goals. Waste loadings were ultimately reduced to the mid-30\% range to regain manageable control (but less than desired) until processing of SB2 was completed.

Although multiple hypotheses, theories, or speculative opinions exist regarding the root cause (or causes) associated with these processing issues, some theories have questioned the appropriateness or applicability of the new $\mathrm{T}_{\mathrm{L}}$ model and/or viscosity model, the impact of the lower viscosity glass on the cold cap behavior or pour stream stability, and the impact of potential crystallization (within the melter or the pour spout) as a result of the higher waste loadings. Other theories have focused on the upstream processes that could potentially have a negative impact on the melter performance. For example, air entrainment in the melter feed could result in rheological properties which do not allow adequate cold cap coverage of the molten glass pool surface thus potentially decreasing the conversion rate (or melt rate) of incoming feed to glass.

In this report, data are provided to gain insight into the potential impact of a lower viscosity glass on melter stability (i.e., pressure spikes, cold cap behavior) and/or pour stream stability. High temperature viscosity data are generated for the Frit 418 - SB3 system as a function of waste loading and compared to similar data for other systems that have been (or are currently being) processed through the DWPF melter. The data are presented in various formats to potentially align the viscosity data with physical observations at various points in the melter system. The data will hopefully provide some insight into critical processing issues that may be related to glass viscosity in an effort to maximize waste throughput. Upon review, the data interpretation could provide a road map from which future frit development efforts can be based (i.e., adjustments to the acceptable viscosity limit range) or physical changes to the melter system could be made to compensate for the known temperature dependence on viscosity.

Objectives for this task are specified in Section 2.0. In Section 3.0, the compositional basis for the sludge and frit are provided. Section 4.0 summarizes the Measurement Acceptability Region (MAR) assessments that led to the selection of specific glass formulations to be tested. In Section 5.0, the experimental procedures are summarized. The results of the compositional analysis and 
viscosity assessments are discussed in detail in Section 6.0. A summary is provided in Section 7.0, with recommendations for future work summarized in Section 8.0. 


\subsection{OBJECTIVE}

The primary objective of this task is to generate viscosity versus temperature data for systems of interest from which engineering judgments can be made with respect to the potential impacts of viscosity on critical processing operations (such as melter and/or pour stream stability). This objective will be accomplished through the evaluation of the impacts of WL on viscosity as well as the relationship between viscosity and temperature for specific systems. A series of Frit $418-$ SB3 glasses is defined (based on MAR assessments) which transitions over a WL interval of interest $(30-45 \%)$. High temperature viscosity data as a function of temperature for each glass are presented in various formats. A comparison of the high temperature viscosity data in this system as compared to previous (Frit 320 - SB2) and current (Frit $202-$ SB3) ${ }^{1}$ systems is also provided.

The data interpretation could provide a road map from which future frit development efforts can be based (i.e., adjustments to the acceptable viscosity limit range) or physical changes to the melter system could be made to compensate for the known temperature dependence on viscosity. The challenge will be to identify the competing effects that govern overall melt rate and pour stream stability and then to obtain a balance (with respect to viscosity) that maximizes waste throughput for DWPF.

This work was performed according to the Westinghouse Savannah River Company (WSRC) Quality Assurance (QA) Program that is responsive to the Department of Energy (DOE) Order 5700.6C, Quality Assurance, 10 CFR 830.120, "Quality Assurance", and other special quality program requirements, as defined in WSRC-RP-92-225, "WSRC Quality Assurance Management Plan", and as directed by the U.S. DOE. These programs are implemented through the use of the 1Q, WSRC QA Manual.

\footnotetext{
${ }^{1}$ Although Frit 418 was initially used to process SB3, DWPF has transitioned to Frit 202 (starting with SME Batch 286) to not only assess the impacts of a higher viscosity system on overall attainment but to also provide a significant cost savings.
} 
WSRC-TR-2004-00429

Revision 0

This page intentionally left blank. 


\subsection{COMPOSITIONAL BASIS}

Various SB3 compositional projections have been used recently to identify candidate frit compositions and to assess projected operating windows (Peeler and Edwards, 2003a). To support this task, the latest compositional projections from the Closure Business Unit (CBU) in March of 2004 will be used. ${ }^{2}$ More specifically, the CBU provided three projected compositions based on various scenarios regarding SB3 given some uncertainties associated with the transfer volumes of Tank 40 and a secondary neptunium (Np) stream. These compositions were designated as: (1) baseline - Tank $51+$ Tank 40 blended on 3/8/2004 + 70\% of the Np solution in Tank 16, (2) Tank 40 current conditions +4 of the $7 \mathrm{~Np}$ transfers, and (3) Tank 40 current conditions +7 of the $7 \mathrm{~Np}$ transfers. The projected compositions are shown in Table 3-1. It is noted that the three compositional views are very similar with differences in the major oxides being less than $1.0 \%$ (i.e., $\mathrm{Na}_{2} \mathrm{O}$ ranges from $20.773 \mathrm{wt} \%$ in the Tank $40+4 \mathrm{~Np}$ transfer case to $21.608 \mathrm{wt} \%$ in the baseline case). These minor differences have no significant impact on the sludge composition to be selected and used in this assessment. The "baseline" case (as defined by the $\mathrm{CBU}$ ) will be used given it has served as the technical basis for a recent study regarding alternative durability options (Edwards et al. 2003, Peeler et al. 2004a and 2004b).

Table 3-1. Projected Compositions (in wt\%) for Three SB3 Cases. (chemical compositions provided by H.H. Elder on 3/15/04)

\begin{tabular}{|c|c|c|c|}
\hline Oxide & Baseline & $\begin{array}{c}\text { Tank } 40+4 \\
\text { Np Transfers }\end{array}$ & $\begin{array}{c}\text { Tank } 40+7 \\
\text { Np Transfers }\end{array}$ \\
\hline $\mathrm{Al}_{2} \mathrm{O}_{3}$ & 15.022 & 14.946 & 14.870 \\
\hline $\mathrm{BaO}$ & 0.145 & 0.156 & 0.156 \\
\hline $\mathrm{CaO}$ & 2.854 & 2.966 & 2.952 \\
\hline $\mathrm{Ce}_{2} \mathrm{O}_{3}$ & 0.234 & 0.258 & 0.258 \\
\hline $\mathrm{Cr}_{2} \mathrm{O}_{3}$ & 0.234 & 0.248 & 0.248 \\
\hline $\mathrm{CuO}$ & 0.088 & 0.100 & 0.100 \\
\hline $\mathrm{Fe}_{2} \mathrm{O}_{3}$ & 32.082 & 33.083 & 32.897 \\
\hline $\mathrm{K}_{2} \mathrm{O}$ & 0.205 & 0.229 & 0.229 \\
\hline $\mathrm{La}_{2} \mathrm{O}_{3}$ & 0.114 & 0.140 & 0.127 \\
\hline $\mathrm{MgO}$ & 3.499 & 3.532 & 3.515 \\
\hline $\mathrm{MnO}$ & 6.559 & 6.353 & 6.327 \\
\hline $\mathrm{Na}_{2} \mathrm{O}$ & 21.608 & 20.773 & 21.218 \\
\hline $\mathrm{NiO}$ & 1.731 & 1.731 & 1.731 \\
\hline $\mathrm{PbO}$ & 0.140 & 0.162 & 0.162 \\
\hline $\mathrm{SiO}_{2}$ & 3.038 & 2.909 & 2.888 \\
\hline $\mathrm{ThO}_{2}$ & 0.034 & 0.046 & 0.046 \\
\hline $\mathrm{TiO}_{2}$ & 0.033 & 0.033 & 0.017 \\
\hline $\mathrm{U}_{3} \mathrm{O}_{8}$ & 10.082 & 10.094 & 10.047 \\
\hline $\mathrm{ZnO}$ & 0.149 & 0.174 & 0.174 \\
\hline $\mathrm{ZrO}_{2}$ & 0.261 & 0.313 & 0.313 \\
\hline Total & 98.113 & 98.246 & 98.275 \\
\hline
\end{tabular}

2 Although a projected composition is being used to support this study, recent DWPF analyses indicate no significant differences in the oxide concentrations. The compositional projections were made available by H.H. Elder on March 15, 2004. 
Table 3-2 summarizes the nominal frit compositions of interest to this study. Peeler and Edwards (2003a) provide a detailed assessment of the Frit 418 development efforts for SB3. DWPF is currently processing SB3 with Frit 202. The interest is not only to assess technical issues associated with overall attainment but is financially-based as well since a large quantity of Frit 202 is on-hand, and its use would result in a significant cost savings. The technical drivers for implementing Frit 202 are based on theories regarding the impact of a low viscosity system on melter stability (or lack thereof) which could have a direct impact on the frequency of the pour spout and/or bellow liner clean-out. The theory suggests that the lower the glass viscosity, the higher the pour spout / bellows liner clean-out frequency. The nominal composition of Frit 320 is also shown in Table 3-2. Frit 320 was developed for and used to process SB2 to improve melt rate (Peeler et al. 2001).

The primary comparisons to be presented are between the Frit 418 - SB3 and Frit 202 - SB3 systems. In addition, information for the Frit 320 - SB2 and Frit 320 - SB3 systems will also be discussed. Edwards et al. (2003) have developed new $\Delta \mathrm{G}_{\mathrm{P}}$ limits which, if implemented, would allow Frit 320 to be processed with SB3. Peeler et al. (2004b) have demonstrated that glasses produced within the Frit 320 - SB3 system are durable (i.e., normalized boron releases on the order of $1.5 \mathrm{~g} / \mathrm{L}$ ). However, prior to further consideration of implementing the new durability limits and using Frit 320 with SB3, melt rate improvements should be demonstrated using the Slurry Fed Melt Rate Furnace (SMRF). Atlhough melt rate can be evaluated, assessments of pressure spikes (probability or the intensity) and/or pour stream instability can not be addressed through current laboratory techniques.

Table 3-2. Nominal Frit Compositions (wt\%).

\begin{tabular}{||c|c|c|c||}
\hline Oxide & Frit 418 & Frit 202 & Frit 320 \\
\hline $\mathrm{B}_{2} \mathrm{O}_{3}$ & 8 & 8 & 8 \\
\hline $\mathrm{Li}_{2} \mathrm{O}$ & 8 & 7 & 8 \\
\hline $\mathrm{Na}_{2} \mathrm{O}$ & 8 & 6 & 12 \\
\hline $\mathrm{SiO}_{2}$ & 76 & 77 & 72 \\
\hline $\mathrm{MgO}$ & - & 2 & - \\
\hline & & & \\
\hline Total & 100 & 100 & 100 \\
\hline
\end{tabular}




\subsection{MAR ASSESSMENTS AND TARGET COMPOSITIONS}

The Nominal Stage assessment proposed by Peeler and Edwards (2002) was used to assess the Frit 418 - SB3 system in terms of SME acceptability. Assessments were made using predictions from models currently implemented in the DWPF over the WL interval of interest $(25-60 \mathrm{wt} \%)$. The property predictions assessed in this study included durability (Product Consistency Test [PCT] [ASTM 2002] response in terms of the preliminary glass dissolution estimator $\left(\Delta \mathrm{G}_{\mathrm{P}}\right)$ (Jantzen et al. 1995)), viscosity at $1150^{\circ} \mathrm{C}\left(\eta_{1150^{\circ}} \mathrm{C}\right), \mathrm{T}_{\mathrm{L}}$, and $\mathrm{Al}_{2} \mathrm{O}_{3}$ and alkali concentrations. Jantzen et al. (1995) and Brown et al. (2001) provide a more detailed discussion on the development of these models. To establish or project operational windows for this system, the predicted properties must be assessed relative to established acceptance criteria. Acceptable predicted properties for this assessment were performed using the MAR limits. Brown, Postles, and Edwards (2002) provide a detailed discussion of how the MAR limits are utilized in the Product Composition Control System (PCCS).

Appendix A provides some of the key property predictions and glass compositional information for the Frit 418- SB3 system which ultimately were used for the PCCS MAR assessment. The last column of Table A1 in Appendix A provides a summary of the MAR assessment at each WL. The presence of a "-" indicates that the targeted glass composition is classified as processable based upon PCCS model predictions (i.e., all process and product performance predictions are acceptable at the MAR). The presence of " $T_{L}$ " and "low $\eta$ " indicate that predictions of $T_{L}$ exceed the MAR limit and predictions of viscosity fail the lower viscosity limit, respectively. Based on this information, the projected operating window for the Frit 418 - SB3 system is $25-46 \%$ WL. At $47 \% \mathrm{WL}$, the system becomes both $\mathrm{T}_{\mathrm{L}}$ and low viscosity limited.

To meet programmatic objectives, six glass compositions were selected (targeting WLs of 30, 33, $35,37,40$, and $45 \%$ ) to span the operating window of interest (shaded in Table A1 of Appendix A). It is noted that in processing the Frit 418 - SB3 system, DWPF has targeted WLs of $\sim 35 \%$ to "optimize" overall attainment and provide maximum waste throughput based on current operating conditions for this system. Table 4-1 summarizes the targeted compositions of the six "VIS" (for VIScosity) glasses. Also shown in Table 4-1 is the predicted viscosity (at $1150^{\circ} \mathrm{C}$ ) for each Frit 418 - SB3 glass based on PCCS. The general trend indicates that as WL increases the viscosity should decrease. 
Table 4-1. Target Compositions and PCCS $\eta_{1150^{\circ} \mathrm{C}}$ Predictions for VIS Glasses. (wt\%, oxide calcine basis) ${ }^{3}$

\begin{tabular}{|c|c|c|c|c|c|c|}
\hline Glass ID & "VIS-1 & "VIS-2 & "VIS-3 & "VIS-4 & "VIS-5 & "VIS-6 \\
\hline WL & $30 \%$ & $33 \%$ & $35 \%$ & $37 \%$ & $40 \%$ & $45 \%$ \\
\hline$\eta_{\left(1150^{\circ} \mathrm{C}\right)}$ & $\mathbf{5 9 . 5 0}$ & 51.96 & 47.16 & 42.56 & 36.05 & 26.34 \\
\hline Oxide & wt\% & wt\% & wt\% & wt $\%$ & wt $\%$ & wt $\%$ \\
\hline $\mathrm{Al}_{2} \mathrm{O}_{3}$ & 4.593 & 5.052 & 5.359 & 5.665 & 6.124 & 6.890 \\
\hline $\mathrm{B}_{2} \mathbf{O}_{3}$ & 5.600 & 5.360 & 5.200 & 5.040 & 4.800 & 4.400 \\
\hline $\mathrm{BaO}$ & 0.044 & 0.049 & 0.052 & 0.055 & 0.059 & 0.059 \\
\hline $\mathrm{CaO}$ & 0.873 & 0.960 & 1.018 & 1.076 & 1.164 & 1.309 \\
\hline $\mathrm{Ce}_{2} \mathrm{O}_{3}$ & 0.072 & 0.079 & 0.084 & 0.088 & 0.096 & 0.107 \\
\hline $\mathrm{Cr}_{2} \mathrm{O}_{3}$ & 0.072 & 0.079 & 0.083 & 0.088 & 0.095 & 0.107 \\
\hline $\mathrm{CuO}$ & 0.027 & 0.030 & 0.031 & 0.033 & 0.036 & 0.040 \\
\hline $\mathrm{Fe}_{2} \mathrm{O}_{3}$ & 9.809 & 10.791 & 11.445 & 12.099 & 13.080 & 14.715 \\
\hline $\mathrm{K}_{2} \mathrm{O}$ & 0.063 & 0.069 & 0.073 & 0.077 & 0.084 & 0.094 \\
\hline $\mathrm{La}_{2} \mathrm{O}_{3}$ & 0.035 & 0.038 & 0.041 & 0.043 & 0.047 & 0.052 \\
\hline $\mathbf{L i}_{2} \mathbf{O}$ & 5.600 & 5.360 & 5.200 & 5.040 & 4.800 & 4.400 \\
\hline MgO & 1.070 & 1.177 & 1.248 & 1.319 & 1.426 & 1.605 \\
\hline MnO & 2.006 & 2.206 & 2.340 & 2.474 & 2.674 & 3.008 \\
\hline $\mathrm{Na}_{2} \mathrm{O}$ & 12.207 & 12.628 & 12.908 & 13.189 & 13.607 & 14.311 \\
\hline $\mathrm{NiO}$ & 0.529 & 0.582 & 0.617 & 0.653 & 0.706 & 0.794 \\
\hline PbO & 0.043 & 0.047 & 0.050 & 0.053 & 0.057 & 0.064 \\
\hline $\mathrm{SiO}_{2}$ & 54.129 & 51.942 & 50.484 & 49.026 & 46.839 & 43.200 \\
\hline $\mathrm{ThO}_{2}$ & 0.010 & 0.012 & 0.012 & 0.013 & 0.014 & 0.016 \\
\hline $\mathrm{TiO}_{2}$ & 0.010 & 0.011 & 0.012 & 0.013 & 0.014 & 0.015 \\
\hline $\mathrm{U}_{3} \mathbf{O}_{8}$ & 3.083 & 3.391 & 3.597 & 3.802 & 4.110 & 4.624 \\
\hline $\mathrm{ZnO}$ & 0.046 & 0.050 & 0.053 & 0.056 & 0.061 & 0.069 \\
\hline $\mathrm{ZrO}_{2}$ & 0.080 & 0.088 & 0.093 & 0.099 & 0.107 & 0.120 \\
\hline Total & 100.00 & 100.00 & 100.00 & 100.00 & 100.00 & 100.00 \\
\hline
\end{tabular}

${ }^{3}$ Glass compositions have been normalized to $100 \%$ given the projected sludge composition listed in Table 3-1 do not sum to $100 \%$. 


\subsection{EXPERIMENTAL}

\subsection{Glass Fabrication}

Each VIS glass was prepared from the proper proportions of reagent-grade metal oxides, carbonates, $\mathrm{H}_{3} \mathrm{BO}_{3}$, and salts in a 150-g batch using the Savannah River National Laboratory (SRNL) technical procedure "Glass Batching" (SRNL 2002a). Batch sheets were filled out as the materials were weighed. Once batched, the glasses were melted using SRNL technical procedure "Glass Melting" (SRNL 2002b). The thoroughly mixed raw materials were placed in a 95\% Platinum $/ 5 \%$ Gold $250-\mathrm{mL}$ crucible and subsequently inserted into a high-temperature furnace at the target melt temperature of $1150^{\circ} \mathrm{C}$. After an isothermal hold at $1150^{\circ} \mathrm{C}$ for $1.0 \mathrm{~h}$, the crucible was removed, and the glass was poured onto a clean stainless steel plate and allowed to air cool.

Approximately $140 \mathrm{~g}$ of glass was removed (poured) from the crucible while $\sim 10 \mathrm{~g}$ remained in the crucible along the walls. The pour patty was used as a sampling stock for the various chemical and physical property measurements (i.e., chemical composition, viscosity, and durability).

\subsection{Chemical Composition Analysis}

To confirm that the "as-fabricated" glasses corresponded to the defined target compositions, a representative sample from each VIS glass pour patty was submitted to the SRNL Mobile Laboratory (SRNL-ML) for chemical analysis. Edwards (see Appendix B) provided an analytical plan that accompanied these samples. This plan identified the cations to be analyzed and the dissolution techniques (i.e., sodium peroxide fusion [PF] and lithium-metaborate [LM]) to be used. Each glass was prepared in duplicate for each cation dissolution technique (PF and LM). Concentrations (as mass \%) for the cations of interest were measured by inductively coupled plasma - atomic emission spectroscopy (ICP - AES). The analytical plan was developed to provide the opportunity to evaluate potential sources of error. Glass standards were intermittently run to assess the performance of the ICP - AES over the course of these analyses and for potential bias-correction needs.

\subsection{High Temperature Viscosity}

Viscosity $(\eta)$ as a function of temperature was measured by a rotating spindle technique (Schumacher and Peeler 1998). Each glass sample was heated to $\sim 1150^{\circ} \mathrm{C}$ in a platinum crucible and maintained until thermal equilibrium was reached. An initial torque reading (at a constant spindle speed) was taken at $\sim 1150^{\circ} \mathrm{C}$ with subsequent measurements at both higher and lower temperatures ranging from $\sim 1000^{\circ} \mathrm{C}$ to $1200^{\circ} \mathrm{C}$ using a hysteresis approach. The hysteresis approach allows for the potential impacts of crystallization (at lower temperatures) and volatilization (at higher temperatures) to be assessed (via reproducibility) with triplicate measurements being taken at $\sim 1150^{\circ} \mathrm{C}$.

The viscosity was calculated from the measured temperature, the percent torque, and the spindle speed. Each set of viscosity - temperature measurements was fit to the Fulcher equation as shown in Equation 1.

$$
\ln (\eta)=A+B /(T-C)
$$


In this equation, $\ln (\eta)$ represents the natural logarithm of the calculated viscosity (Poise), and A, $\mathrm{B}$, and $\mathrm{C}$ represent the parameters of the Fulcher equation. The temperature (in degree Celsius or ${ }^{\circ} \mathrm{C}$ ) is represented as T. Viscosities at various temperatures were then predicted using the fitted Fulcher equation for each VIS glass.

Traditional glass science views of viscosity data are also included in this report. A plot of $\log \eta$ versus temperature will be made to gain insight into potential differences among the VIS glasses in terms of WL. Not only will consistency between the shape of the curves be assessed, but differences among the steepness (or slope) of the curves over various temperature intervals will be evaluated - with steepness/slope being an indication of the change in viscosity for a given change in temperature.

Over temperature ranges of a few hundred degrees, the Fulcher equation is sufficiently accurate for many measurements and the viscosity may be expressed approximately as the sum of two exponential terms (Equation (2)):

$$
\eta=A \exp (B / R T)+A_{1} \exp \left(B^{1} / R T\right)
$$

When plotting $\log \eta$ against $1 / \mathrm{T}$, the data can be fitted approximately by two straight lines and B and $\mathrm{B}^{1}$ can thus be referred to as the "high" and "low" temperature activation energies (i.e., the slope of the two lines). ${ }^{4}$ Given the measured viscosity data for the VIS glasses were taken over a limited but higher temperature interval $\left(\sim 1000-1200^{\circ} \mathrm{C}\right)$, the "high temperature" data will be fit to provide insight into any slope differences among the various waste loading glasses. The slope provides insight into potential activation energy differences as a function of WL.

\subsection{Product Consistency Test (PCT)}

Although not a primary objective, the PCT was performed in triplicate on each "quenched" VIS glass to assess chemical durability using technical procedure "Standard Test Methods for Determining Chemical Durability of Nuclear Waste Glasses: The Product Consistency Test (PCT)" (ASTM 2002). ${ }^{5}$ Also included in this experimental test matrix were the Environmental Assessment (EA) glass (Jantzen et al. 1993), the Approved Reference Material (ARM) glass, and blanks. Samples were ground, washed, and prepared according to procedure. Fifteen milliliters of Type I ASTM water were added to $1.5 \mathrm{~g}$ of glass in stainless steel vessels. The vessels were closed, sealed, and placed in an oven at $90 \pm 2{ }^{\circ} \mathrm{C}$ where the samples were maintained for 7 days. The resulting solutions (once cooled) were sampled (filtered and acidified), labeled (according to the analytical plan), and analyzed. Edwards provided an analytical plan for the SRNL-ML analysis (see Appendix C). The overall philosophy of the plan was to provide an opportunity to assess the consistency (repeatability) of the PCT and analytical procedures in an effort to evaluate chemical durability of the VIS glasses. Normalized release rates were calculated based on targeted, measured, and bias-corrected compositions using the average of the logs of the leachate concentrations.

To bound the effects of thermal history on the product performance, approximately $25 \mathrm{~g}$ of each VIS glass were heat treated to simulate cooling along the centerline of a DWPF-type canister

\footnotetext{
${ }^{4}$ Equation (2) can be used if viscosity data is obtained over a large temperature interval which typically requires two types of measurement methods. In the high temperature regime, a rotating spindle could be used; while in the low temperature regime (near softening point) a beam bending method may be required. 5 The PCT information is being generated in support of developing a compositional - property database to assess alternative durability approaches for DWPF (see Peeler et al. 2003b).
} 
(Marra and Jantzen 1993). This cooling regime is commonly referred to as the centerline canister cooled (ccc) curve. This terminology will be used in this report to differentiate samples from different cooling regimes (quenched versus $\mathrm{ccc}$ ). PCTs were conducted in triplicate for these glasses and were included in the analytical plan. 
WSRC-TR-2004-00429

Revision 0

This page intentionally left blank. 


\subsection{RESULTS}

In the sections that follow the experimental results from this study are discussed. In Section 6.1 the chemical composition measurements of the VIS glasses are presented and discussed. Section 6.2 provides a discussion of the viscosity measurements of the VIS glasses while Section 6.3 discusses the PCT measurements (both quenched and centerline canister cooled) of the glasses.

\subsection{A Statistical Review of the Chemical Composition Measurements}

In this section, the measured versus targeted compositions of the 6 VIS study glasses (VIS-1 through VIS-6) are presented and compared. The targeted compositions for these glasses were provided in Table 3-1 and are also listed in Table D1 of Appendix D. A sum of oxides column is provided in this table as well. Chemical composition measurements for these glasses were conducted by the SRNL-ML following an analytical plan provided in Appendix B. This analytical plan included the 6 VIS glasses of interest in this study as well as 8 glasses, labeled ADT-1 through ADT-8, which were part of a separate study. Two dissolution methods were utilized in measuring these chemical compositions: samples prepared by LM dissolution were used to measure elemental concentrations of aluminum (Al), barium $(\mathrm{Ba})$, calcium $(\mathrm{Ca})$, cerium $(\mathrm{Ce})$, chromium $(\mathrm{Cr})$, copper $(\mathrm{Cu})$, iron $(\mathrm{Fe})$, potassium $(\mathrm{K})$, lanthanum $(\mathrm{La})$, magnesium $(\mathrm{Mg})$, manganese $(\mathrm{Mn})$, sodium $(\mathrm{Na})$, nickel $(\mathrm{Ni})$, lead $(\mathrm{Pb})$, silicon $(\mathrm{Si})$, thorium $(\mathrm{Th})$, titanium $(\mathrm{Ti})$, uranium $(\mathrm{U})$, zinc $(\mathrm{Zn})$, and zirconium $(\mathrm{Zr})$ while samples from glasses prepared by $\mathrm{PF}$

dissolution were used to measure elemental concentrations of boron (B) and lithium (Li). For each study glass, measurements were obtained from samples prepared in duplicate by each of these dissolution methods. All of the prepared samples were analyzed (twice for each element of interest) by ICP - AES (with the instrumentation being re-calibrated between the duplicate analyses).

Table D2 in Appendix D provides the elemental concentration measurements derived from the samples prepared using LM, and Table D3 in Appendix D provides the measurements derived from the samples prepared using PF. Measurements for standards (Batch 1 and a uranium standard, $\left.\mathrm{U}_{\text {std }}\right)$ that were included in the SRNL-ML analytical plan along with the VIS and ADT (Alternative Durabilty Glasses) study glasses are also provided in these two tables.

The elemental concentrations were converted to oxide concentrations by multiplying the values for each element by the gravimetric factor for the corresponding oxide. During this process, an elemental concentration that was determined to be below the detection limit of the analytical procedures used by the SRNL-ML was reduced to half of that detection limit as the oxide concentration was determined.

In the sections that follow, the analytical sequences of the measurements are explored, the measurements of the standards are investigated and used for bias correction, the measurements for each glass are reviewed, the average chemical compositions (measured and bias-corrected) for each glass are determined, and comparisons are made between the measurements and the targeted compositions for the glasses.

\subsubsection{Measurements in Analytical Sequence}

Exhibit D1 in Appendix D provides plots of the measurements generated by the SRNL-ML for samples prepared using the LM method. The plots are in analytical sequence with different symbols and colors being used to represent each of the study and standard glasses. Similar plots 
for samples prepared using the PF method are provided in Exhibit D2 in Appendix D. These plots include all of the measurement data from Tables D2 and D3. That is, the plots include the ADT study glasses as well as the VIS study glasses. A review of these plots indicates no significant patterns or trends in the analytical process over the course of these measurements, and there appear to be no obvious outliers in these chemical composition measurements. The ADT study glasses are not included in the discussion that follows but the reader is referred to Peeler et al. (2004a) and Peeler et al. (2004b).

\subsubsection{Batch 1 and Uranium Standard Results}

In this section, the SRNL-ML measurements of the chemical compositions of the Batch 1 and $\mathrm{U}_{\text {std }}$ glasses are reviewed. These measurements are investigated across the ICP analytical blocks, and the results are used to bias correct the measurements for the VIS glasses.

Exhibit D3 in Appendix D provides statistical analyses of the Batch 1 and $\mathrm{U}_{\text {std }}$ results generated by the LM prep method by analytical block for each oxide of interest. The results include analysis of variance (ANOVA) investigations looking for statistically significant differences among the block means for each of the oxides for each of the standards. The results from the statistical tests for the Batch 1 standard may be summarized as follows: the $\mathrm{BaO}, \mathrm{Fe}_{2} \mathrm{O}_{3}, \mathrm{~K}_{2} \mathrm{O}$, $\mathrm{MgO}, \mathrm{Na}_{2} \mathrm{O}$, and $\mathrm{TiO}_{2}$ measurements indicate a significant ICP calibration effect on these averages at the 5\% significance level. For the $\mathrm{U}_{\text {std }}$, the $\mathrm{Al}_{2} \mathrm{O}_{3}, \mathrm{CuO}, \mathrm{Fe}_{2} \mathrm{O}_{3}, \mathrm{MgO}, \mathrm{Na}_{2} \mathrm{O}, \mathrm{TiO}_{2}$, and $\mathrm{U}_{3} \mathrm{O}_{8}$ measurements indicate a significant ICP calibration effect on these averages at the $5 \%$ significance level. The reference values for the oxide concentrations of the standard are given in the header for each set of measurements in the exhibit.

Exhibit D4 in Appendix D provides a similar set of analyses for the measurements derived from samples prepared via the PF method. In this exhibit, none of measurements for Batch 1 indicate a significant ICP calibration effect on these averages at the 5\% significance level while the measurements for $\mathrm{B}_{2} \mathrm{O}_{3}$ for $\mathrm{U}_{\text {std }}$ show significant ICP calibration effects on these averages at the $5 \%$ significance level. The reference values for the oxide concentrations of the standard are given in the headers for each set of measurements in the exhibit.

Overall the results suggest that it may be helpful to bias correct the oxide measurements of the VIS glasses for the effect of the ICP calibration on each of the analytical blocks. The basis for this bias correction is presented as part of Exhibits $\mathrm{D} 3$ and $\mathrm{D} 4$ - the average measurement for Batch 1 for each ICP block for $\mathrm{Al}_{2} \mathrm{O}_{3}, \mathrm{~B}_{2} \mathrm{O}_{3}, \mathrm{BaO}, \mathrm{CaO}, \mathrm{Cr}_{2} \mathrm{O}_{3}, \mathrm{CuO}, \mathrm{Fe}_{2} \mathrm{O}_{3}, \mathrm{Li}_{2} \mathrm{O}, \mathrm{MgO}, \mathrm{MnO}$, $\mathrm{Na}_{2} \mathrm{O}, \mathrm{NiO}, \mathrm{SiO}_{2}$, and $\mathrm{TiO}_{2}$ and the average measurement for $\mathrm{U}_{\text {std }}$ for each ICP block for $\mathrm{U}_{3} \mathrm{O}_{8}$. The Batch 1 results served as the basis for bias correcting all of the oxides (that were bias corrected) except uranium. The $\mathrm{U}_{\text {std }}$ results were used to bias correct for uranium. For the other oxides, the Batch 1 results were used to conduct the bias correction as long as the reference value for the oxide concentration in the Batch 1 glass was greater than or equal to $0.1 \mathrm{wt} \%$. Thus, applying this approach and based upon the information in the exhibits, the Batch 1 results were used to bias correct the $\mathrm{Al}_{2} \mathrm{O}_{3}, \mathrm{~B}_{2} \mathrm{O}_{3}, \mathrm{BaO}, \mathrm{CaO}, \mathrm{Cr}_{2} \mathrm{O}_{3}, \mathrm{CuO}, \mathrm{Fe}_{2} \mathrm{O}_{3}, \mathrm{~K}_{2} \mathrm{O}, \mathrm{Li}_{2} \mathrm{O}, \mathrm{MgO}, \mathrm{MnO}$, $\mathrm{Na}_{2} \mathrm{O}, \mathrm{NiO}, \mathrm{SiO}_{2}$, and $\mathrm{TiO}_{2}$ measurements. No bias correction was conducted for $\mathrm{Ce}_{2} \mathrm{O}_{3}, \mathrm{La}_{2} \mathrm{O}_{3}$, $\mathrm{PbO}, \mathrm{ThO}_{2}, \mathrm{ZnO}$, or $\mathrm{ZrO}_{2}$.

The bias correction was conducted as follows. For each oxide, let $\overline{\mathrm{a}}_{\mathrm{ij}}$ be the average measurement for the $i^{\text {th }}$ oxide at analytical block $j$ for Batch 1 (or $U_{\text {std }}$ for uranium), and let $t_{i}$ be the reference value for the $\mathrm{i}^{\text {th }}$ oxide for Batch 1 (or for $\mathrm{U}_{\text {std }}$ if uranium). (The averages and 
reference values are provided in Exhibits D3 and D4.) Let $\overline{\mathrm{c}}_{\mathrm{ijk}}$ be the average measurement for the $\mathrm{i}^{\text {th }}$ oxide at analytical block $\mathrm{j}$ for the $\mathrm{k}^{\text {th }}$ glass. The bias adjustment was conducted as follows

$$
\bar{c}_{i j k} \bullet\left(1-\frac{\bar{a}_{i j}-t_{i}}{\bar{a}_{i j}}\right)=\bar{c}_{i j k} \bullet \frac{t_{i}}{\bar{a}_{i j}}
$$

Bias-corrected measurements are indicated by a "bc" suffix, and such adjustments were performed for all of the oxides of this study except for $\mathrm{Ce}_{2} \mathrm{O}_{3}, \mathrm{La}_{2} \mathrm{O}_{3}, \mathrm{PbO}, \mathrm{ThO}_{2}, \mathrm{ZnO}$, and $\mathrm{ZrO}_{2}$. Both measured and measured "bc" values are included in the discussion that follows. In these discussions bias-corrected values for $\mathrm{Ce}_{2} \mathrm{O}_{3}, \mathrm{La}_{2} \mathrm{O}_{3}, \mathrm{PbO}, \mathrm{ThO}_{2}, \mathrm{ZnO}$, and $\mathrm{ZrO}_{2}$ are included for completeness (e.g., to allow a sum of oxides to be computed for the bias-corrected results). These bias-corrected values are the same as the original $\mathrm{Ce}_{2} \mathrm{O}_{3}, \mathrm{La}_{2} \mathrm{O}_{3}, \mathrm{PbO}, \mathrm{ThO}_{2}, \mathrm{ZnO}$, and $\mathrm{ZrO}_{2}$ values (i.e., once again, no bias correction was performed for this group of oxides).

\subsubsection{Composition Measurements by Glass Number}

Exhibits D5 and D6 in Appendix D provide plots of the oxide concentration measurements by Glass ID (including both Batch 1 and $\mathrm{U}_{\mathrm{std}}$ ) for the measured and bias-corrected (bc) values for the LM and PF preparation methods, respectively. Different symbols and colors are used to represent the different glasses. These plots show the individual measurements across the duplicates of each preparation method and the two ICP calibrations. A review of the plots presented in these exhibits reveals the repeatability of the four individual, oxide values for each glass. There appears to be a good bit of scatter in the $\mathrm{Fe}_{2} \mathrm{O}_{3}, \mathrm{Na}_{2} \mathrm{O}$, and $\mathrm{SiO}_{2}$ values. No other problems are evident in these plots.

More detailed discussions of the average, measured chemical compositions of the study glasses are provided in the next section.

\subsubsection{Measured versus Targeted Compositions}

The four measurements for each oxide for each glass (over both preparation methods) were averaged to determine a representative chemical composition for each glass. These determinations were conducted both for the measured and for the bias-corrected data. A sum of oxides was also computed for each glass based upon both the measured and bias-corrected values. Exhibit D7 in Appendix D provides plots showing results for each glass for each oxide to help highlight the comparisons among the measured, bias-corrected, and targeted values.

Some observations from the plots of Exhibit D7 are offered: For every VIS glass the measured $\mathrm{Al}_{2} \mathrm{O}_{3}$ values are greater than their respective targeted concentrations. For $\mathrm{Fe}_{2} \mathrm{O}_{3}, \mathrm{NiO}$ and $\mathrm{ZrO}_{2}$ the measured values for most of the study glasses fall below their respective targets for these oxides. The detection limits of the ICP - AES for $\mathrm{ThO}_{2}$ is higher than the targeted values therefore the values appear to be consistently higher than targeted. In addition, the $\mathrm{Cr}_{2} \mathrm{O}_{3}$ value for the $\mathrm{U}_{\mathrm{STD}}$ glass is approximately $0.25 \mathrm{wt} \%$ were the reported value is $0.0 \mathrm{wt} \%$. This observation is consistent with previous results (Peeler et al. 2004c).

Table D4 in Appendix D provides a summary of the average compositions as well as the targeted compositions and some associated differences and relative differences. Notice that the targeted sums of oxides for the standard glasses do not sum to $100 \%$ due to an incomplete coverage of the 
oxides in the Batch 1 (glass \# 100) and $U_{\text {std }}$ (glass 101) glasses. All of the sums of oxides (both measured and bias-corrected) for the study glasses fall within the interval of 95 to $105 \mathrm{wt} \%$.

Entries in Table D4 show the relative differences between the measured or bias-corrected values and the targeted values. These differences are shaded when they are greater than or equal to $5 \%$. Overall, these comparisons between the measured and targeted compositions suggest that there were some difficulties in hitting the targeted compositions for some of the oxides for some of the glasses. However, these differences are not seen as being of practical concern.

\subsection{A Critical Review of the Viscosity Information}

\subsubsection{DWPF Start-Up Frit (Standard) Results}

To ensure the viscosity measurements were performed under control and the viscometer was appropriately calibrated, the viscosity of a "standard glass" was measured prior to and after measurement of the VIS "unknown" glasses. DWPF start-up frit that is being considered for a national viscosity standard for high-level waste glasses given its viscosity-temperature relationship is similar to most DWPF and Hanford high-level waste glass compositions. ${ }^{6}$ An additional driver was the fact that current National Institute of Standards and Technology (NIST) viscosity glasses are either unavailable or less than ideal for calibration of equipment to measure viscosity of high level waste glasses.

The measured data were fit to the Fulcher equation to estimate the A, B, and C parameters. Exhibits E1 - E4 in Appendix E summarize the Fulcher fits for the DWPF start-up frit. The equation was then used to predict the $\eta_{1150^{\circ} \mathrm{C}}$ value for each standard glass tested during this study and these predictions are summarized in Table 6-1. The average $\eta_{1150^{\circ} \mathrm{C}}$ value based on the four measurements from this study is 41.12 Poise with a standard deviation of 0.8706 . For comparison, the average predicted $\eta_{1150^{\circ} \mathrm{C}}$ based on the round robin results is 41.75 Poise. $^{7}$ These data provide a measure of confidence in the VIS glass data to be presented.

Table 6-1. DWPF Start-Up Frit (Standard) Compared to Round Robin Results. ( $\eta$ in Poise)

\begin{tabular}{||l|c||}
\hline & Average \\
\hline Round Robin Results & $\mathbf{4 1 . 7 5}$ \\
\hline & \\
\hline Results from this study & \\
\hline DWPF-1 (5/4/04) & 40.81 \\
\hline DWPF-2 (5/18/04) & 40.04 \\
\hline DWPF-3 (6/7/04) & 41.94 \\
\hline DWPF-4 (6/8/04) & 41.70 \\
\hline & \\
\hline Average & $\mathbf{4 1 . 1 2}$ \\
\hline Std Dev & 0.8706 \\
\hline$\%$ RSD & $2.12 \%$ \\
\hline
\end{tabular}

\footnotetext{
${ }^{6}$ SRNL participated in a national round robin program to assess and establish the DWPF Start-up Frit as a viscosity standard. Other participants in the program included commercial and national laboratories.

7 The reported average value for the DWPF Start-up frit of 41.75 Poise is based on the latest version of the viscosity round robin report from Pacific Northwest National Laboratory (PNNL).
} 


\subsubsection{Viscosity Versus Temperature Data for the VIS Glasses}

Table 6-2 summarizes the viscosity versus temperature data for each VIS glass. As noted in Section 5.3 , the use of the hysteresis type curve provides the opportunity to assess the potential impacts of volatility and/or crystallization. Three viscosity readings at $\sim 1150^{\circ} \mathrm{C}$ are provided (and bolded in Table 6-2) for each glass. The data suggest that the triplicate measurements for each glass are within $\pm 2-3$ Poise with the recognition that the actual temperature measurements are not exactly $1150^{\circ} \mathrm{C}$. These data suggest that the impacts of volatility at high temperatures $\left(1200^{\circ} \mathrm{C}\right)$ and crystallization on the low temperature data are minimal and of no practical concern. To support the viscosity measurements, room temperature density was measured for each glass which is reported in Table 6-2 for completeness.

Table 6-2. Viscosity Versus Temperature Data for the VIS Glasses.

\begin{tabular}{||c|c||}
\hline \multicolumn{2}{|c||}{ VIS-1 } \\
\hline \multicolumn{2}{|c|}{$30 \% \mathrm{WL}$} \\
\hline \multicolumn{2}{|c|}{ Density $=2.6725$} \\
\hline Temp ( $\left.{ }^{\circ} \mathrm{C}\right)$ & Visc (Poise) \\
\hline $\mathbf{1 1 4 9 . 5}$ & $\mathbf{4 1 . 7 8}$ \\
\hline 1199.5 & 29.42 \\
\hline $\mathbf{1 1 5 0}$ & $\mathbf{4 1 . 9 4}$ \\
\hline 1100 & 62.58 \\
\hline 1049.5 & 99.15 \\
\hline $\mathbf{1 1 5 0}$ & $\mathbf{4 3 . 9 3}$ \\
\hline
\end{tabular}

\begin{tabular}{||c|c||}
\hline \multicolumn{2}{|c|}{ VIS-4 } \\
\hline \multicolumn{2}{|c|}{$37 \% \mathrm{WL}$} \\
\hline \multicolumn{2}{|c|}{ Density $=2.7437$} \\
\hline Temp $\left({ }^{\circ} \mathrm{C}\right)$ & Visc (Poise) \\
\hline $\mathbf{1 1 5 1 . 5}$ & $\mathbf{3 2 . 3 9}$ \\
\hline 1201 & 22.46 \\
\hline $\mathbf{1 1 5 2 . 5}$ & $\mathbf{3 1 . 9 2}$ \\
\hline 1102 & 47.88 \\
\hline 1050 & 75.46 \\
\hline 1000.5 & 121.96 \\
\hline $\mathbf{1 1 5 1 . 5}$ & $\mathbf{3 2 . 3 9}$ \\
\hline
\end{tabular}

\begin{tabular}{||c|c|}
\hline \multicolumn{2}{|c|}{ VIS-2 } \\
\hline \multicolumn{2}{|c|}{$33 \% \mathrm{WL}$} \\
\hline \multicolumn{2}{|c|}{ Density $=2.6973$} \\
\hline Temp $\left({ }^{\circ} \mathrm{C}\right)$ & Visc (Poise) \\
\hline $\mathbf{1 1 5 0 . 5}$ & $\mathbf{3 8 . 5 5}$ \\
\hline 1199 & 27.13 \\
\hline $\mathbf{1 1 5 1 . 5}$ & $\mathbf{3 8 . 7 1}$ \\
\hline 1098 & 59.51 \\
\hline 1047.5 & 93.79 \\
\hline 999.5 & 151.44 \\
\hline $\mathbf{1 1 5 0}$ & $\mathbf{3 9 . 7 1}$ \\
\hline
\end{tabular}

\begin{tabular}{||c|c||}
\hline \multicolumn{2}{|c|}{ VIS-5 } \\
\hline \multicolumn{2}{|c|}{$40 \% \mathrm{WL}$} \\
\hline \multicolumn{2}{|c|}{ Density $=2.7668$} \\
\hline Temp $\left({ }^{\circ} \mathrm{C}\right)$ & Visc (Poise) \\
\hline $\mathbf{1 1 4 9 . 5}$ & $\mathbf{3 1 . 1 3}$ \\
\hline 1199.5 & 21.65 \\
\hline $\mathbf{1 1 5 1 . 5}$ & $\mathbf{3 0 . 9 5}$ \\
\hline 1099.5 & 47.14 \\
\hline 1050 & 73.00 \\
\hline $\mathbf{1 1 5 1}$ & $\mathbf{3 1 . 2 0}$ \\
\hline
\end{tabular}

\begin{tabular}{||c|c||}
\hline \multicolumn{2}{|c||}{ VIS-3 } \\
\hline \multicolumn{2}{|c||}{$35 \%$ WL } \\
\hline \multicolumn{2}{|c||}{ Density $=2.7187$} \\
\hline Temp $\left({ }^{\circ} \mathrm{C}\right)$ & Visc (Poise) \\
\hline $\mathbf{1 1 4 9 . 5}$ & $\mathbf{3 6 . 4 2}$ \\
\hline 1199.5 & 25.33 \\
\hline $\mathbf{1 1 5 0}$ & $\mathbf{3 6 . 4 1}$ \\
\hline 1098.5 & 55.42 \\
\hline 1048 & 86.61 \\
\hline $\mathbf{1 1 5 0}$ & $\mathbf{3 6 . 9 1}$ \\
\hline
\end{tabular}

\begin{tabular}{||c|c||}
\hline \multicolumn{2}{|c||}{ VIS-6 } \\
\hline \multicolumn{2}{|c||}{$45 \% \mathrm{WL}$} \\
\hline \multicolumn{2}{|c|}{ Density $=2.8098$} \\
\hline Temp $\left({ }^{\circ} \mathrm{C}\right)$ & Visc (Poise) \\
\hline $\mathbf{1 1 4 8 . 5}$ & $\mathbf{2 4 . 8 6}$ \\
\hline 1199.5 & 17.00 \\
\hline $\mathbf{1 1 5 1}$ & $\mathbf{2 4 . 3 5}$ \\
\hline 1100.5 & 37.04 \\
\hline 1049.5 & 59.61 \\
\hline 997.5 & 105.32 \\
\hline $\mathbf{1 1 5 0 . 5}$ & $\mathbf{2 5 . 6 8}$ \\
\hline
\end{tabular}




\subsubsection{Fulcher Fits and $\eta_{1150^{\circ} \mathrm{C}}$ Values for Each VIS Glass}

The Fulcher fit parameters (determined based on the measured data and developed in Appendix E) are provided in Table 6-3 for each VIS glass (as well as the four standard glasses). In addition, the predicted $\eta_{1150^{\circ} \mathrm{C}}$ values based on the fitted equation are shown. The data indicate that as WL increases in the Frit $418-\mathrm{SB} 3$ system the viscosity decreases. The $\eta_{1150^{\circ} \mathrm{C}}$ values range from 42.33 to 24.77 Poise at $30 \%$ and $45 \%$ WL, respectively. This trend is consistent with PCCS model predictions (see Appendix A) - however, the magnitude of the $\eta_{1150^{\circ} \mathrm{C}}$ values at a particular WL differ (as will be discussed in the Section 6.2.4).

Table 6-3. Fit Parameters and $\eta_{1150^{\circ} \mathrm{C}}$ Values for the VIS Glasses.

\begin{tabular}{|c|c|c|c|c|c||}
\hline Glass & WL (\%) & A & B & C & $\eta_{1150}(\mathbf{P})$ \\
\hline DWPF Startup Frit 5-4-04 & - & -4.30265 & 8085.20307 & 140.80238 & 40.81 \\
\hline DWPF Startup Frit 5-18-04 & - & -4.47147 & 8429.67114 & 117.12088 & 40.04 \\
\hline VIS-01 & $\mathbf{3 0}$ & -4.12580 & 8132.30808 & 116.85358 & $\mathbf{4 2 . 3 3}$ \\
\hline VIS-02 & $\mathbf{3 3}$ & -4.72243 & 9091.67316 & 66.20703 & $\mathbf{3 9 . 1 1}$ \\
\hline VIS-03 & $\mathbf{3 5}$ & -5.37991 & 10441.09666 & -12.92780 & $\mathbf{3 6 . 5 4}$ \\
\hline VIS-04 & $\mathbf{3 7}$ & -5.18351 & 9828.94210 & 16.28207 & $\mathbf{3 2 . 6 6}$ \\
\hline VIS-05 & $\mathbf{4 0}$ & -5.53676 & 10403.15297 & -8.56636 & $\mathbf{3 1 . 2 7}$ \\
\hline VIS-06 & $\mathbf{4 5}$ & -3.56535 & 5884.79610 & 281.40462 & $\mathbf{2 4 . 7 7}$ \\
\hline DWPF Startup Frit 6-7-04 & - & -3.76412 & 7230.81640 & 185.93344 & 41.94 \\
\hline DWPF Startup Frit 6-8-04 & - & -4.55891 & 8622.72794 & 109.79624 & 41.70 \\
\hline \hline
\end{tabular}

Using the fit parameters shown in Table 6-3, the Fulcher equation was used to predict the viscosity at various temperatures for each VIS glass. The predicted viscosities (based on measured data) are shown in Table 6-4 for temperatures of $950^{\circ}, 1000^{\circ}, 1050^{\circ}, 1100^{\circ}, 1150^{\circ}$, and $1200^{\circ} \mathrm{C}$. It should be noted that the entries "shaded" in Table 6-4 indicate that the predicted values are based on an extrapolation of the Fulcher equation. More specifically, all of the $950^{\circ} \mathrm{C}$ predicted values (and $1 / 2$ of the $1000^{\circ} \mathrm{C}$ values) are extrapolated from the Fulcher fit as a formal viscosity reading was not taken (see Table 6-2 for specific temperatures where viscosity values were obtained).

Once again, the trends in the data indicate that as WL increases, viscosity decreases for a fixed temperature. In addition, as temperatures decrease, the viscosity increases (non-linearly) for a fixed WL. These trends are graphically presented in Figure 6-1 on a $\eta$ versus temperature plot. The non-linear relation between viscosity and temperature is typical of inorganic glasses. The curves demonstrate that for a fixed change in temperature $(\Delta T)$, the change in viscosity $(\Delta \eta)$ becomes more dramatic in the lower temperature range. Therefore, when one discusses the impacts of glass viscosity on melt rate and/or pour stream stability the viscosity response of the glass could be markedly different depending on the magnitude of the $\Delta \mathrm{T}$ as well as the temperature range over which the change occurs. Therefore, it is critical to understand not only the dependence of the viscosity versus temperature curve but also the temperature regimes in which links to physical effects should be made. These data could be used to potentially estimate the viscosity of the glass at critical locations within the melter. More specifically, the glass 
moving through the melter riser, throat, or pour spout may (or may not) have time to thermally equilibrate to a known (or estimated) temperature based on a fixed thermocouple due to velocity or flow characteristics. ${ }^{8}$

Table 6-4. Predicted Viscosities at Various Temperatures Using Fulcher Fit.

\begin{tabular}{||c|c|c|c|c|c|c|c||}
\hline \hline Glass & $\mathbf{W L}$ & $\eta_{\mathbf{9 5 0}}$ & $\eta_{\mathbf{1 0 0 0}}$ & $\boldsymbol{\eta}_{\mathbf{1 0 5 0}}$ & $\eta_{\mathbf{1 1 0 0}}$ & $\eta_{\mathbf{1 1 5 0}}$ & $\boldsymbol{\eta}_{\mathbf{1 2 0 0}}$ \\
\hline VIS-01 & 30 & 280.10 & 161.18 & 98.41 & 63.18 & 42.33 & 29.44 \\
\hline VIS-02 & 33 & 261.04 & 150.48 & 91.75 & 58.68 & 39.11 & 27.01 \\
\hline VIS-03 & 35 & 235.84 & 138.09 & 85.03 & 54.69 & 36.54 & 25.24 \\
\hline VIS-04 & 37 & 209.17 & 122.50 & 75.55 & 48.72 & 32.66 & 22.65 \\
\hline VIS-05 & 40 & 203.58 & 118.87 & 73.03 & 46.88 & 31.27 & 21.57 \\
\hline VIS-06 & 45 & 187.99 & 101.90 & 59.81 & 37.47 & 24.77 & 17.13 \\
\hline
\end{tabular}

${ }^{8}$ At a pour rate of $160 \mathrm{lbs} / \mathrm{hr}$, the linear velocity of glass in the DWPF riser is approximately 2"/min. 


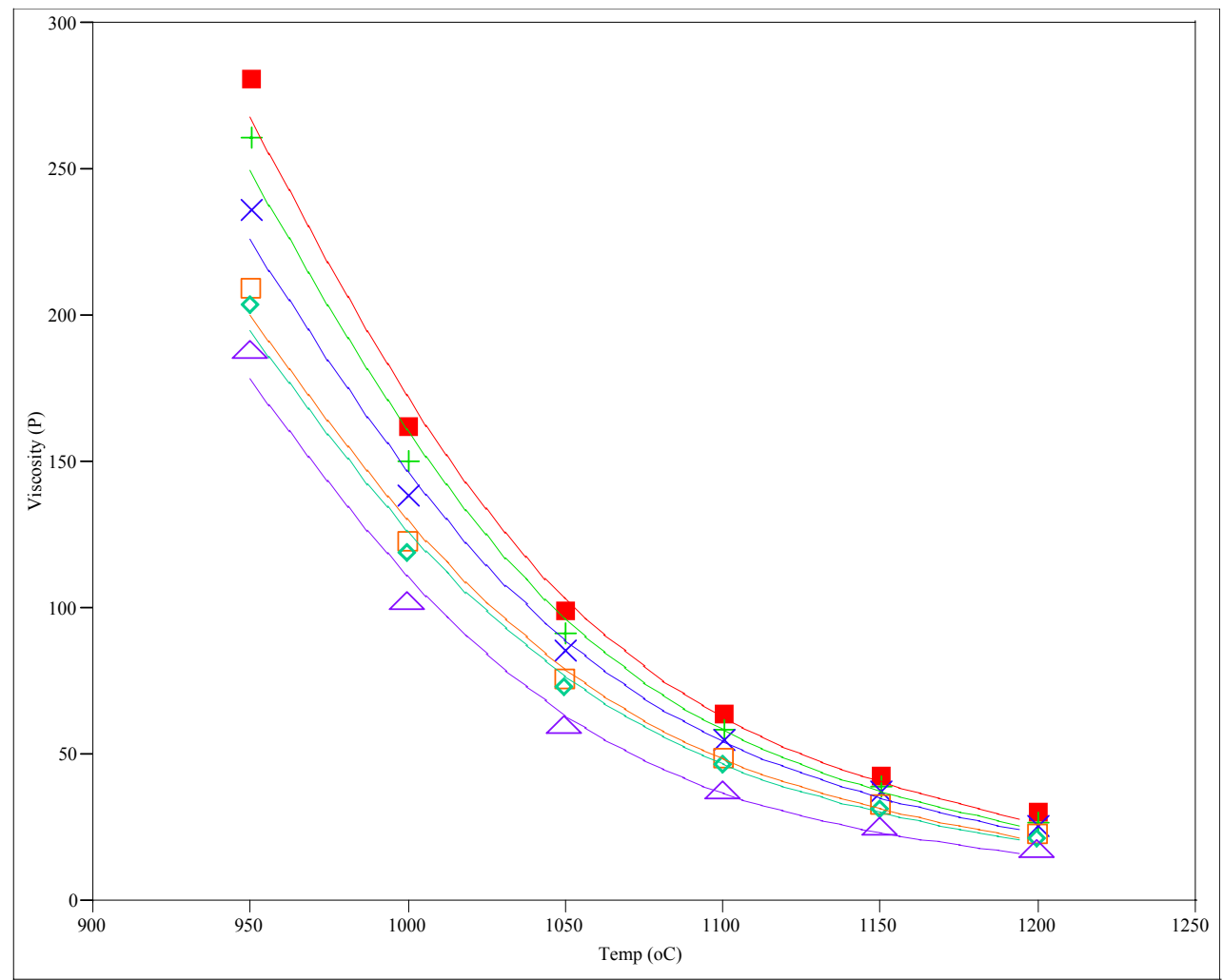

Smoothing Spline Fit, lambda $=100000 \quad \mathrm{WL}==30$
Smoothing Spline Fit, lambda $=100000 \mathrm{WL}==33$
Smoothing Spline Fit, lambda $=100000 \mathrm{WL}==35$
Smoothing Spline Fit, lambda $=100000 \mathrm{WL}==37$
Smoothing Spline Fit, lambda $=100000 \mathrm{WL}==40$
Smoothing Spline Fit, lambda $=100000 \mathrm{WL}==45$

$\begin{array}{lc}\text { Smoothing Spline Fit, lambda }=100000 & \mathrm{WL}=30 \\ \text { R-Square } & 0.992728 \\ \text { Sum of Squares Error } & 326.6375 \\ \text { Smoothing Spline Fit, lambda }=100000 & \mathrm{WL}=33 \\ \text { R-Square } & 0.99288 \\ \text { Sum of Squares Error } & 278.8314 \\ \text { Smoothing Spline Fit, lambda }=100000 & \mathrm{WL}=35 \\ \text { R-Square } & 0.99342 \\ \text { Sum of Squares Error } & 208.5704 \\ \text { Smoothing Spline Fit, lambda }=100000 & \mathrm{WL}=37 \\ \text { R-Square } & 0.993377 \\ \text { Sum of Squares Error } & 164.642 \\ \text { Smoothing Spline Fit, lambda }=100000 & \mathrm{WL}=40 \\ \text { R-Square } & 0.993342 \\ \text { Sum of Squares Error } & 157.6542 \\ \text { Smoothing Spline Fit, lambda }=100000 & \mathrm{WL}=45 \\ \text { R-Square } & 0.990564 \\ \text { Sum of Squares Error } & 197.4708\end{array}$

Figure 6-1. Viscosity Versus Temperature for the VIS Glasses. 
Figure 6-2 plots the Frit $418-\mathrm{SB} 3$ data in terms of $\log \eta$ against 1/T. Given the measured viscosity data for the VIS glasses were taken over a limited but higher temperature interval (1000 $-1200^{\circ} \mathrm{C}$ ), the "high temperature" data are approximated by a linear fit with the slope providing insight into potential activation energy differences as a function of WL. Although a formal activation energy is not calculated, the slopes of the six VIS glasses do not show any major deviation suggesting very little if any difference in activation energy among the systems as a function of WL. ${ }^{9}$ Table 6-5 summarizes the linear fits and estimated slopes for each system.

Although not realized for the VIS glasses, the slope of the log $\eta$ against 1/T (or activiation energy) can provide insight into the "workability" of the glass system. ${ }^{10}$ Consider two glasses, Glass A and Glass B, with hypothetically two different activiation energies. In this example, Glass A has a lower activiation energy as compared to Glass B. The lower activation energy indicates that for a given change in temperature $(\Delta T)$, the change in viscosity $(\Delta \eta)$ is much smaller as compared to the $\Delta \eta$ for Glass B (for the same $\Delta \mathrm{T}$ ). This situation is referred to as a "long-glass" as it provides a long working range over which relatively small changes in viscosity occur for a given change in temperature. Glass B is considered to be a "short glass" as small changes in temperature result in significant changes in viscosity which shorten the working range of the glass (i.e., the glass sets up more rapidly). Figure 6-3 provides an example of this effect for specific systems of interest to DWPF.

Table 6-5. Estimated Fits and Slopes of the VIS Glasses.

\begin{tabular}{||c|c|c|c||}
\hline \hline Glass ID & WL & Linear Fit & Slope \\
\hline VIS-1 & 30 & $y: \log (\operatorname{Visc}\{\mathrm{P}\})=-3.168079+0.6825585 \mathrm{x}:[10000 / \mathrm{T}(\mathrm{K})]$ & 0.6825585 \\
\hline VIS-2 & 33 & $\mathrm{y}: \log (\operatorname{Visc}\{\mathrm{P}\})=-3.328426+0.7004381 \mathrm{x}:[10000 / \mathrm{T}(\mathrm{K})]$ & 0.7004381 \\
\hline VIS-3 & 35 & $\mathrm{y}: \log (\operatorname{Visc}\{\mathrm{P}\})=-3.261167+0.6866321 \mathrm{x}:[10000 / \mathrm{T}(\mathrm{K})]$ & 0.6866321 \\
\hline VIS-4 & 37 & $\mathrm{y}: \log (\operatorname{Visc}\{\mathrm{P}\})=-3.319413+0.6880039 \mathrm{x}:[10000 / \mathrm{T}(\mathrm{K})]$ & 0.6880039 \\
\hline VIS-5 & 40 & $\mathrm{y}: \log (\operatorname{Visc}\{\mathrm{P}\})=-3.346708+0.6891801 \mathrm{x}:[10000 / \mathrm{T}(\mathrm{K})]$ & 0.6891801 \\
\hline VIS-6 & 45 & $\mathrm{y}: \log (\operatorname{Visc}\{\mathrm{P}\})=-3.725936+0.7289327 \mathrm{x}:[10000 / \mathrm{T}(\mathrm{K})]$ & 0.7289327 \\
\hline
\end{tabular}

\footnotetext{
${ }^{9}$ A more thorough assessment of the upper and lower 95\% confidence intervals for each VIS glass indicates that slopes are similar (i.e., the confidence bands overlap).

${ }^{10}$ In the commercial glass sector, the term "workability" commonly refers to the ease with which glass can be worked into a variety of forms. Depending upon the length of the temperature interval between minimum and maximum viscosities at which the glass can be shaped the glass can be classified as a "long" (or "good natured") glass or a "short" glass.
} 
WSRC-TR-2004-00429

Revision 0

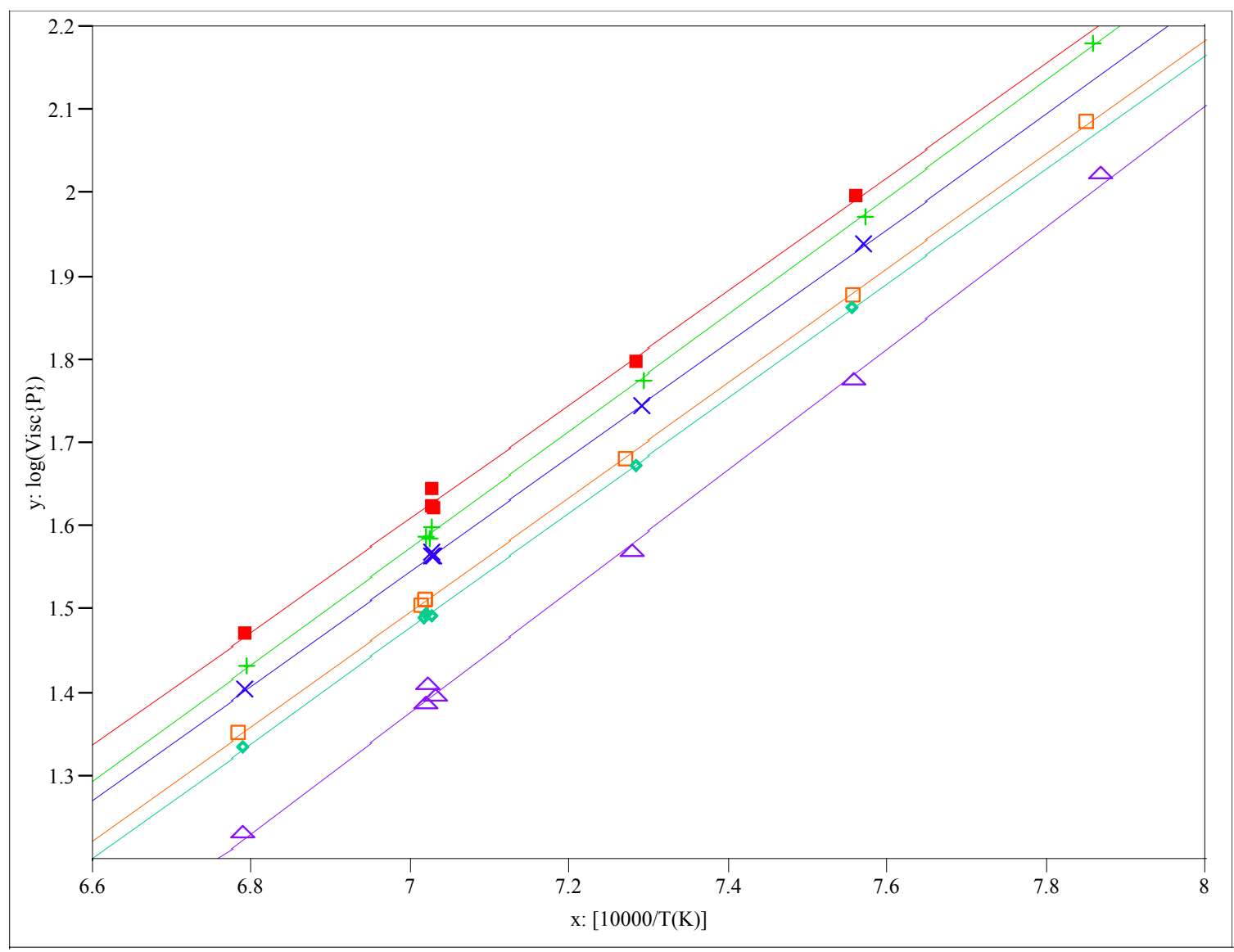

$$
\begin{aligned}
\text { Linear Fit } W L= & =30 \\
\text { Linear Fit } W L & ==33 \\
\text { Linear Fit } W L= & =35 \\
\text { Linear Fit } W L= & =37 \\
\text { Linear Fit } W L= & =40 \\
\text { Linear Fit } W L & ==45
\end{aligned}
$$

Figure 6-2. $\log \eta$ against 1/T (K) for the VIS Glasses. 

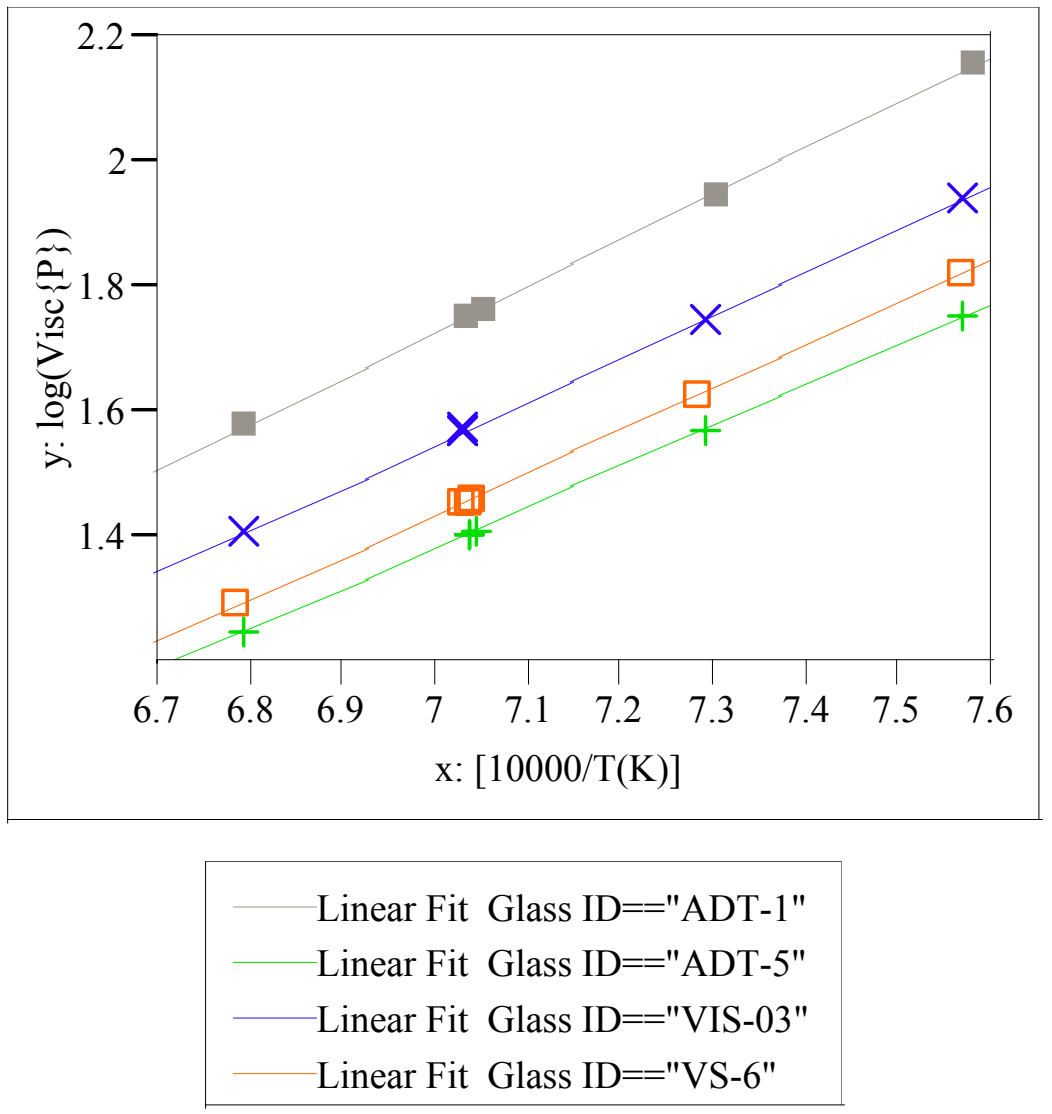

Figure 6-3. $\log \eta$ against 1/T (K) for Various Glass Systems of Interest.

As previously mentioned, the slope of the $\log \eta$ against $1 / T$ (or activation energy) can provide insight into the "workability" of the glass system. In Figure 6-3, the measured data for four systems of interest to DWPF are plotted. These systems include: Frit 202 - SB3 (ADT-1), Frit 320 - SB3 (ADT-5), Frit 418 - SB3 (VIS-03), and Frit 320 - SB2 (VS-6). It should be noted that with the exception of VS-6 (Frit 320 - SB2) all of the glasses target a WL of 35\%. VS-6 targeted a SB2 WL of 34\%. Table 6-6 summarizes the estimated slopes and lower and upper confidence limits (LCL and UCL, respectively) for each system. The data indicate that there is a significant difference between the slopes of 3 of the 4 systems. VIS-3 and VS- 6 have statistically insignificant slopes of approximately 0.68 which indicates that the viscosity responses (for a given $\Delta \mathrm{T}$ ) between the Frit 418 - SB3 and Frit 320 - SB2 systems would be very similar.

Table 6-6. Estimated Fits and Slopes of the VIS Glasses.

\begin{tabular}{||c|c|c|c|c|c|c||}
\hline Glass ID & WL & Frit & Sludge & Slope & LCL & UCL \\
\hline ADT-1 & 35 & 202 & SB3 & 0.735777 & 0.7229961 & 0.7485579 \\
\hline ADT-5 & 35 & 320 & SB3 & 0.6489476 & 0.6403529 & 0.6575423 \\
\hline VIS-3 & 35 & 418 & SB3 & 0.6866321 & 0.6717275 & 0.7015368 \\
\hline VS-6 & 34 & 320 & SB2 & 0.6810365 & 0.6690735 & 0.6929996 \\
\hline \hline
\end{tabular}


The slope for the ADT-1 glass (Frit $202-\mathrm{SB} 3$ at 35\% WL) is approximately 0.74 . The LCL and UCL values indicate no overlap with either the Frit 320 - SB3 (ADT-5) or Frit 418 - SB3 (VIS3) glasses. With the slope of the Frit 202 - SB3 system being higher as compared to the other two SB3 systems, these data indicate that the Frit 202 - SB3 system is a "shorter" glass as small changes in temperature would result in more significant changes in viscosity which shorten the working range of the glass (i.e., the glass sets up more rapidly). These data also indicate that the "working range" of the SB3 system can be altered by adjustments to frit composition. In terms of ranking the SB3 system from "short" to "long" glasses based on the estimated slopes, Frit 202 is the "shortest glass (slope of $\sim 0.74$ ), Frit 418 being an "intermediate" (slope of $\sim 0.69$ ), and the Frit 320 system is the "longer" glass (slope of $\sim 0.65$ ).

\subsubsection{Model Predictions Versus Experimental Data}

In Sections 6.2.2 and 6.2.3, the measured data for the VIS glasses were presented and fit to the Fulcher equation to provide predicted viscosity values at various temperatures. The current DWPF viscosity model also predicts the viscosity of a glass at $1150^{\circ} \mathrm{C}$. A comparison of the Fulcher fit predictions (based on measured data) and the PCCS model predictions are shown in Table 6-7. The last three columns of Table 6-6 show the predicted viscosities based on target (Table 4-1or Table D1 in Appendix D), measured (Table D4 in Appendix D), and measured biascorrected (Table D4 in Appendix D) compositions, respectively. These three compositional views result in differences in the predicted viscosity via PCCS for each VIS glass. These differences range from $\sim 2.5$ Poise for VIS-06 to 6.5 Poise for VIS-04. These differences reflect possible batching errors and/or analytical uncertainties. In general, the PCCS $\eta_{1150^{\circ} \mathrm{C}}$ predictions indicate that as WL increase in the Frit 418 - SB3 system, viscosity decrease which is consistent with the Fulcher fit trend. The exceptions to this trend are the predicted values for VIS-02 and VIS-03 using measured bias-corrected compositions which are basically equivalent.

Although the trends in the viscosity versus WL data are relatively consistent, a potentially significant difference is observed when magnitudes are compared. For example, the PCCS predictions for VIS-01 (30\% WL) are between $\sim 14-18$ Poise higher than the Fulcher fit predictions based on measured viscosity data. This apparent bias in the PCCS model decreases as WLs increase or viscosities decrease to the point of being within experimental error (or at least of no practical concern) at $45 \%$ WL.

Table 6-7. "Measured $\eta_{1150}$ " (based on Fulcher fit of measured data) Versus PCCS Predictions.

\begin{tabular}{||c|c|c|c|c|c||}
\hline \hline Glass & WL & $\begin{array}{c}\text { Fulcher } \\
\eta_{\mathbf{1 1 5 0}}\end{array}$ & $\begin{array}{c}\text { PCCS } \\
\eta_{\mathbf{1 1 5 0} \text { (target) }}\end{array}$ & $\begin{array}{c}\text { PCCS } \\
\eta_{\mathbf{1 1 5 0} \text { (measured) }}\end{array}$ & $\begin{array}{c}\text { PCCS } \\
\eta_{\mathbf{1 1 5 0} \text { (m-bc) }}\end{array}$ \\
\hline VIS-01 & 30 & 42.33 & 59.5 & 60.51 & 56.28 \\
\hline VIS-02 & 33 & 39.11 & 51.96 & 50.66 & 46.97 \\
\hline VIS-03 & 35 & 36.54 & 47.16 & 52.37 & 47.43 \\
\hline VIS-04 & 37 & 32.66 & 42.56 & 44.18 & 37.56 \\
\hline VIS-05 & 40 & 31.27 & 36.05 & 37.23 & 33.50 \\
\hline VIS-06 & 45 & 24.77 & 26.34 & 28.82 & 26.48 \\
\hline \hline
\end{tabular}

A specific example of the bias observed that the authors wish to discuss is the Frit $418-\mathrm{SB} 3$ system at 35\% WL. When DWPF transitioned to the Frit 418 - SB3 system, WLs of $\sim 35 \%$ were ultimately targeted which provided a relatively high overall attainment. It is interesting to note 
that the predicted viscosity based on the targeted composition at $35 \% \mathrm{WL}$ is 47.16 Poise. In reality, the viscosity of the system at $35 \%$ WL may be closer to 36.5 Poise (based on the measured data for VIS-03). If the Frit 418 - SB3 system is meeting DWPF expectations in terms of melt rate, WL, waste throughput, and facility attainment, one should factor the potential bias into the discussions regarding establishing a new lower viscosity limit or range. This bias has been observed in other DWPF glass systems (as discussed below). 
Table 6-8 summarizes the $\eta_{1150^{\circ} \mathrm{C}}$ predictions (based on the Fulcher fit prediction or estimated based on the measured triplicates at $1150^{\circ}$ ) and the PCCS model predictions (using targeted compositions) for four different glass systems at two WLs. The glass systems being compared in Table 6-7 included:

(1) Frit 320 - SB2 (VS series, see Peeler et al. 2003),

(2) Frit 418 - SB3 (VIS series, results of this study),

(3) Frit 202 - SB3 (ADT series, see Peeler et al. 2004b), and

(4) Frit 320 - SB3 (ADT series, see Peeler et al. 2004b).

The Frit 320 - SB2 data are presented and discussed first given historical sequencing through the DWPF. Based on targeted compositions and using the current PCCS viscosity model, this system was predicted to have $\eta_{1150^{\circ} \mathrm{C}}$ 's of approximately 35 and 27 Poise at 34 and $40 \% \mathrm{WL}$, respectively. The predicted viscosities based on a Fulcher fit of the measured data are approximately 28 and 26 Poise (Peeler et al. 2003). As previously discussed (and noted in Table 6-5) with the Frit 418 - SB3 system, as WL increased (or viscosity decreased) the bias in the predictions seems to dissipate or narrow to the point of no practical concern - consistent with the reported viscosity data for the Frit 320 - SB2 system. As discussed in Section 1.0, when DWPF began targeting higher WLs (between $35-40 \%$ ) for the Frit 320 - SB2 system, subsequent operations began experiencing "negative" processing or operational issues (i.e., a transition from one pour interruption every 2.5 canisters to one pour interruption every canister). These included large pressure spikes resulting in an off-gas system switch over (which can cause pouring to stop or result in large quantities of glass to pour in a short time) as well as frequent plugging of the pour spout / bellows liner, observations regarding the instability of the pour stream and "excessive" amounts of material within the pour spout. These observations lead to the initial link between melter instability and low viscosity systems as overall attainment was significantly reduced. However, it should be noted that other issues could have contributed or even resulted in the impact of higher WLs on overall attainment (as discussed below).

Processing of Frit 418 - SB3 through DWPF resulted in more stable melter processing (less frequent and less intense pressure spikes). However, pour stream instability, as a result of these pressure spikes, is still problematic - although the use of the heated bellows liner has been beneficial. The predicted viscosities (based on Fulcher fits of the measured data) for the Frit 418 - SB3 system ranges from $\sim 36$ to 31 Poise, at 35 and 40\% WL respectively. Those values can be compared to 47 to 36 Poise (at 35 and $40 \%$ WL, respectively) based on PCCS model predictions. Again, the apparent bias is larger at lower WLs or higher viscosities. 
WSRC-TR-2004-00429

Revision 0

Table 6-8. $\eta_{1150^{\circ} \mathrm{C}}$ Predicted Based on Fulcher Fit and PCCS Models for Various Flowsheets.

\begin{tabular}{||c|c|c|c|c|c||}
\hline Glass & Frit & $\begin{array}{c}\text { Sludge } \\
\text { Batch }\end{array}$ & WL & $\begin{array}{c}\eta_{\text {1150 }} \\
\text { (measured data) }\end{array}$ & $\begin{array}{c}\text { PCCS } \\
\eta_{\text {1150 (target comps) }}\end{array}$ \\
\hline VS-611 & 320 & SB2 & 34 & $28.17^{*}$ & 35.11 \\
\hline VS-9 & 320 & SB3 & 40 & $25.63^{*}$ & 26.91 \\
\hline VIS-03 & 418 & SB3 & 35 & $36.54^{*}$ & 47.16 \\
\hline VIS-05 & 418 & SB3 & 40 & $31.27^{*}$ & 36.05 \\
\hline ADT-01 & 202 & SB3 & 35 & $\sim 55$ Poise & 70.48 \\
\hline ADT-02 & 202 & SB3 & 40 & $\sim 45$ Poise & 53.95 \\
\hline ADT-05 & 320 & SB3 & 35 & $\sim 25$ Poise & 26.60 \\
\hline ADT-06 & 320 & SB3 & 40 & $\sim 23$ Poise & 20.10 \\
\hline
\end{tabular}

"*” indicates values from Fulcher fit using measured data

When comparing the measured viscosity data between the Frit 320 - SB2 and Frit 418 - SB3 systems at $\sim 35 \% \mathrm{WL}$, and considering the general differences in melter and/or pour stream stability observations, one may conclude that a viscosity lower than $\sim 37$ Poise (based on measured data) or $\sim 41$ Poise (based on PCCS model predictions) should not be targeted. However, the reduction in melter instability may not be solely the response of a higher viscosity system, but other factors could be playing a role such as sludge composition, degree of sludge washing, acid addition strategy, feed rheology, air entrainment, and/or cold cap behavior (such as ability to spread). It should be noted that the measured viscosity data for these two systems indicate only an $\sim 8$ Poise shift in the $\eta_{1150^{\circ} \mathrm{C}}$ - not a significant shift in viscosity but markedly different processing characteristics.

To assess the impact of a higher viscosity system on melter and pour stream stability, DWPF has recently transitioned to Frit 202 (starting with SME Batch \#278). PCCS model predictions suggested that the viscosity would increase from $\sim 47$ Poise (with Frit 418 ) to $\sim 71$ Poise (with Frit 202 ) if a $35 \% \mathrm{WL}$ glass was targeted - an $\sim 24$ Poise difference. However, based on the Fulcher fit of the measured data an $\sim 18$ Poise difference was observed ( $\sim 55$ Poise versus $\sim 37$ Poise for the Frit 202 and Frit 418 systems, respectively, at 35\% WL). Although the data are limited for the Frit 202 based system in DWPF, it appears that there is no correlation between melter stability (i.e., pressure spikes) and viscosity. However, initial observations do suggest that the higher viscosity system is having a positive impact on pour stream stability. ${ }^{12}$ Coupling these observations with a slight increase in canister-to-canister fill time (due to a lower melt rate), defining or determining the targeted viscosity to maximize attainment that ultimately meets waste throughput expectation (measured by equivalent canisters produced) will be a balancing act as there are competing factors throughout the process. From a melt rate perspective, glass formulation efforts are pushed toward maximizing the alkali content of the glass which based on previous testing has shown to be highly correlated to melt rate (Peeler et al. 2001, Smith and

11 The viscosity data for VS-6 and VS-9 were obtained from SRT-GPD-2003-00124 (Peeler et al. 2003).

12 In general terms, an improvement in pour stream stability has been observed (at a given feed rate) when the viscosity was increased by going from the Frit 320 - SB2 system to the Frit 418 - SB3 system. Qualitatively, the pour stream in the Frit 418 - SB3 system seems to be less effected by pressure perturbations than the pour stream of the Frit 320 - SB2 system. The lack of correlation between melter stability and viscosity in the Frit 202 - SB3 system may be due to the lower melt rate of this feed relative to the Frit 418 - SB3 system. 
Jones 2003, Smith et al. 2003). This compositional direction will tend to lower the overall glass viscosity. The resulting increase in melt rate may be attributed to differences in cold cap reactions and/or increased convection currents within the molten glass pool (due to the lower viscosity) which ultimately sweeps or replenishes "hot" glass to the cold cap / melt pool interface expediting conversion of the incoming feed to glass. However, the down stream effects of a low viscosity system may adversely impact pour stream stability to such a degree that overall attainment is lowered (even though melt rate is high). Therefore, the challenge will be to find a viscosity (or viscosity range) that strikes a balance among melter stability and melt rate that allows DWPF to meet (or exceed) processing expectations. This latter statement does not include any physical changes that have been or could be made to the melter (e.g., the glass pump may be able to compensate for a lower melt rate system while maintaining adequate pour stream stability characteristics).

The data presented potentially transitions away from theories linking viscosity to melter instability (or pressure spikes) given there is a small delta in the viscosity data between Frit 202 and Frit 418 systems (using measured data). That delta may not warrant a strong connection between viscosity and melter instability. However, it does not rule out the potential impacts of viscosity on pour stream stability.

\subsubsection{Physical Interpretation of the Viscosity Versus Temperature Data}

In terms of a physical interpretation of the data, a few hypotheses, theories, or speculative opinions are presented and discussed below. The theories presented are certainly not an all inclusive list and the order in which they are presented does not imply a ranking, probability, or likelihood that the proposed theory is even plausible. The intent of this discussion is to provide a forum in which the viscosity data can be discussed in relation to possible mechanisms which potentially could help lead to a workable solution as a higher overall attainment is strived for during processing of the current or future sludge batches.

Multiple hypotheses, theories, or speculative opinions exist regarding the root cause (or causes) associated with recent processing issues in the DWPF. Some of the theories have questioned the appropriateness or applicability of the new $\mathrm{T}_{\mathrm{L}}$ model and/or viscosity model, the impact of the lower viscosity glass on the cold cap behavior or pour stream stability, and the impact of potential crystallization (within the melter or the pour spout) as a result of the higher waste loadings. Other theories have focused on the upstream processes that could potentially have a negative impact on the melter performance. For example, air entrainment in the melter feed could result in rheological properties which do not allow adequate cold cap coverage of the molten glass pool surface thus potentially decreasing the conversion rate (or melt rate) of incoming feed to glass.

Prior to a general discussion of possible physical connections between viscosity and melter observations, a general understanding of the viscosity response to temperature must be coupled with the thermal perturbations of the melter as the glass transitions from the melter through the pour spout where it ultimately physically disengages as it travels into the canister. Given viscosity is a glass property that is directly related to composition and temperature, one must discuss the impacts with respect to both chemical and thermal homogeneity.

Chemical homogeneity of the glass is of little concern given the residence times within the melter and previous pour stream sample analysis results. Thermal homogeneity refers to an equal temperature distribution within a given volume or unit of glass. As the glass travels through the melter system it can experience a range of temperatures and its ability to reach thermal homogeneity may depend on glass flow or velocities. For example, the nominal glass pool in 
DWPF melter is approximately $1150^{\circ} \mathrm{C}$ while temperatures in the pour spout can be as low as 950 $-1000^{\circ} \mathrm{C}$. It has been estimated that the linear velocity of the glass in the DWPF melter riser is approximately $2 \% / \mathrm{min}$ (assuming a $160 \mathrm{lb} / \mathrm{hr}$ pour rate) which should be adequate for the glass to respond to these temperature changes. A primary result of the temperature change will be a shift in glass viscosity. The data shown in Figure 6-1 demonstrates that for a fixed change in temperature $(\Delta \mathrm{T})$, the shift in viscosity $(\Delta \eta)$ for the Frit 418 - SB3 system becomes more dramatic in the lower temperature range. Therefore, when one discusses the impacts of glass viscosity on melter and/or pour stream stability the viscosity response of the glass could be markedly different depending on the magnitude of the $\Delta \mathrm{T}$ as well as the temperature range over which the change occurs. Therefore, it is critical to understanding not only the dependence of the viscosity versus temperature curve but the temperature regimes in which links to physical effects should be made. More specifically, it may be inappropriate to use the measured or predicted viscosity at $1150^{\circ} \mathrm{C}$ as a parameter to make decisions regarding pour stream stability - perhaps the viscosity at a lower temperature should be assessed. It should be noted that previous assessments of melt rate have indicated a direct link to the total alkali content of the glass which directly impacts overall viscosity of the final glass product. The trend has been that higher alkali contents increase melt rate which may be attributed to differences in cold cap reactions and/or increased convection currents within the molten glass pool (due to a lower viscosity glass) which ultimately sweeps or replenishes "hot" glass to the cold cap / melt pool interface.

So how do the proposed theories and physical phenomena observed during recent DWPF melter campaigns align with the reported viscosity data? For the Frit 418 - SB3 system, the general viscosity data trends indicate that as WL increases, viscosity decreases for a fixed temperature. In addition, as temperatures decrease, the viscosity increases (non-linearly) for a fixed WL.

In simplistic terms and assuming all other factors equal, lower viscosity glasses would be more susceptible to "movement" for a given applied force (i.e., a pressure spike). An analogy for this hypothesis is to consider a bucket of water and a bucket of molasses - for a given force (e.g., kick the bucket) more perturbations are expected from the bucket containing water than the bucket containing molasses. In general, this is in line with recent DWPF observations - prompting the decision to utilize Frit 202 with SB3 and consideration of establishing a higher lower viscosity limit for future frit development efforts. ${ }^{13}$ It should also be noted that although a positive outcome may be expected from a pour stream stability perspective as viscosity is increased, other factors may experience a negative impact (Miller 2004). As previously mentioned, one such critical factor is melt rate which ultimately plays a role in defining waste throughput. Therefore a balance may be necessary to achieve maximum attainment assuming no physical changes are made to the melter or pour spout.

Another hypothesis that potentially relates the observed pressure spikes with glass viscosity is the concept of a "sinking cold cap or mound of unreacted feed". Although the cold cap is a low density mass, the hypothesis suggests that as the viscosity of the molten glass pool decreases, the probability that a mass of unreacted feed could submerge into the molten glass increases. The analogy could be dropping a marble into a water bath versus molasses (although a primary difference being the density of the cold cap may prevent rapid settling or settling altogether). If rapid settling or sinking did occur, cold cap reactions which typically occur over some extended time period as temperatures progress through the cold cap, could take place instantaneously resulting in the sudden release of a large volume of gas. Theory suggests that having a lower viscosity glass pool would increase this possibility. However, the data presented in this report

13 The current PAR viscosity limits being used to guide glass formulation or frit development efforts are 20 -110 Poise at $1150^{\circ} \mathrm{C}$. 
coupled with DWPF observations tends to draw one's attention away from this scenario. More specifically, the small viscosity differences (based on measured data) between the Frit 202 - SB3 and Frit 418 - SB3 systems does not warrant a strong connection between viscosity and melter instability.

Another theory that has surfaced relates the viscosity of the molten glass pool to the "stability" of the cold cap. This theory implies that as the viscosity of the molten glass pool supporting the cold cap becomes lower, the stability of the cold cap is reduced (e.g., movement of the cold cap on the glass surface increases). The theory then suggests that as the cold cap moves over the glass pool, fissures or cracks could be promoted which allow feed or water to be rapidly exposed to higher temperature releasing significant volumes of off-gas leading to pressure surges or spikes. It has been speculated that the degree or the intensity of the pressure spikes observed in the melter are in line with a large volume of steam resulting from a sudden reaction.

Again, the intent of this report is not to advocate or criticize any of the theories discussed above. The intent of this report is to provide the data from which engineering judgments or decisions can be made as to possible causes/mechanisms for melter and pour stream instability in order to develop working solutions. Those solutions could be either physical changes to the system (e.g., adding heat to a critical or troublesome spots in the glass riser, throat, or pour spout that could take advantage of the viscosity versus temperature relationship) or chemical changes manifested through frit or waste loadings changes. Based on those decisions, guidance for targeting a specific viscosity range for future sludge batches may also be warranted.

\subsection{A Statistical Review of the PCT Measurements}

The VIS study glasses, after being batched and fabricated, were subjected to the 7-day PCT to assess their durabilities. More specifically, Method A of the PCT (ASTM C1285-97 [ASTM 2002]) was used for these measurements. Durability is the critical (or primary) product quality metric for DWPF glass studies. The PCTs were conducted in triplicate for each of two heat treatments (quenched and centerline canister cooled). PCTs were also conducted in triplicate for samples of the EA glass and for samples of the ARM glass. Blanks (samples consisting only of ASTM Type I water) were also submitted for the PCT.

An analytical plan, presented in Appendix C, was provided to the SRNL-ML to support the measurement of the compositions of the solutions resulting from the PCTs. This analytical plan included the PCTs for the VIS glasses of interest in this study as well as the ADT glasses, which were part of a separate study. Samples of a multi-element, standard solution were also included in each analytical plan (as a check on the accuracy of the ICP - AES used for these measurements). In this and the following sections, the measurements generated by the SRNLML for these PCTs are presented and reviewed.

Table F1 in Appendix F provides the elemental leachate concentration measurements determined by the SRNL-ML for the solution samples generated by the PCTs covered in the analytical plan. One of the quality control checkpoints for the PCT procedure is solution-weight loss over the course of the 7-day test. While none of these PCT results indicated a solution-weight loss problem, the contents of one vessel were spilled and lost. No measurements were possible for this PCT, which is indicated as a shaded row in Table F1. Any measurement in Table F1 below the detection limit of the analytical procedure (indicated by a "<") was replaced by $1 / 2$ of the detection limit in subsequent analyses. In addition to adjustments for detection limits, the values were adjusted for the dilution factors: the values for the study glasses, the blanks, and the ARM glass in Table F1 were multiplied by 1.6667 to determine the values in parts per million (ppm) 
and the values for EA were multiplied by 16.6667. Table F2 in Appendix F provides the resulting measurements including those from the ADT glasses.

In the sections that follow, the analytical sequence of the measurements is explored, the measurements of the standards are investigated and used to assess the overall accuracy of the ICP measurement process, the measurements for each glass are reviewed, plots are provided that explore the effects of the heat treatment on the PCTs for these glasses, the PCTs are normalized using the compositions (targeted, measured, and bias-corrected) presented in Table F4, and the normalized PCTs are compared to durability predictions for these compositions generated from the current DWPF models (Jantzen et al. 1995).

\subsubsection{Measurements in Analytical Sequence}

Exhibits F1 and F2 in Appendix F provide plots of the leachate (ppm) concentrations in analytical sequence as generated by the SRNL-ML for all of the data including the ADT glass results and for only the VIS study glasses, respectively. A different color is used for each type of sample with a small, solid square used to represent a centerline canister cooled (ccc) glass and a plus being used to represent a quenched glass. The blanks and solution standard results are also represented using small squares while the ARM results are represented by an open circle and the EA results by a closed circle. No problems are seen in these plots, and the ADT results are not included in the discussion that follows.

\subsubsection{Results for the Samples of the Multi-Element Solution Standard}

Exhibit F3 in Appendix F provides analyses of the SRNL-ML measurements of the samples of the multi-element solution standard by ICP analytical (or calibration) block. An ANOVA investigating for statistically significant differences among the block averages for these samples for each element of interest is included in these exhibits. These results indicate a statistically significant (at the 5\% level) difference among the $\mathrm{Al}, \mathrm{Fe}, \mathrm{Li}, \mathrm{Na}$, and $\mathrm{Si}$ average measurements over these blocks. However, no bias correction of the PCT results for the study glasses was conducted. This approach was taken since the triplicate PCTs for a single study glass were placed in different ICP blocks. Averaging the ppm's for each set of triplicates helps to minimize the impact of the ICP effects.

Table 6-9 summarizes the average measurements and the reference values for the 4 primary elements of interest. The results indicate consistent and accurate measurements from the SRNLML processes used to conduct these analyses.

Table 6-9. Results from Samples of the Multi-Element Solution Standard.

\begin{tabular}{||c|c|c|c|c||}
\hline $\begin{array}{c}\text { Set/ } \\
\text { Analytical Block }\end{array}$ & $\begin{array}{c}\text { Avg B } \\
(\mathbf{p p m})\end{array}$ & $\begin{array}{c}\text { Avg Li } \\
(\mathbf{p p m})\end{array}$ & $\begin{array}{c}\text { Avg Na } \\
(\mathbf{p p m})\end{array}$ & $\begin{array}{c}\text { Avg Si } \\
\text { (ppm) }\end{array}$ \\
\hline 1 & 20.53 & 9.67 & 79.53 & 48.83 \\
\hline 2 & 20.23 & 9.60 & 79.93 & 48.23 \\
\hline 3 & 19.87 & 9.65 & 79.90 & 48.13 \\
\hline 4 & 20.20 & 9.66 & 81.00 & 47.43 \\
\hline 5 & 20.83 & 9.81 & 82.43 & 49.97 \\
\hline 6 & 20.97 & 9.65 & 79.63 & 48.90 \\
\hline Grand Average & 20.44 & 9.67 & 80.41 & 48.58 \\
\hline Reference Value & 20 & 10 & 81 & 50 \\
\hline \% difference & $2.19 \%$ & $-3.26 \%$ & $-0.73 \%$ & $-2.83 \%$ \\
\hline
\end{tabular}




\subsubsection{Measurements by Glass Number}

Exhibits F4 and F5 in Appendix F provide plots of the leachate concentrations for each type of submitted sample: the study glasses and the standards (EA, ARM, the multi-element solution standard, and blanks) with EA and the blanks and without them, respectively. These plots allow for the assessment of the repeatability of the measurements, which suggests some scatter in the triplicate values for some analytes for some of the glasses. None of the values have been excluded from the calculations that follow, however.

\subsubsection{Quenched versus Centerline Canister Cooled PCTs}

Exhibit F6 in Appendix F provides a closer look at the effect of heat treatment on the PCTs of the VIS glasses. This exhibit provides a paired-t test comparing the quenched and ccc versions of each glass for each analyte. Based upon the results of this exhibit, only Na shows a statistically significant (at the 5\% significance level) difference between the quenched PCTs and the ccc PCTs. For this analyte, the quenched PCTs leached higher than their ccc counterparts, about 3.4 $\mathrm{ppm}$ more for Na. These data suggest that there is no practical diference in the PCT response between the quenched and ccc glasses on average.

\subsubsection{Normalized PCT Results}

PCT leachate concentrations are typically normalized using the cation composition (expressed as a weight percent) in the glass to obtain a grams-per-liter $(\mathrm{g} / \mathrm{L})$ leachate concentration. The normalization of the PCTs is usually conducted using the measured compositions of the glasses. This is the preferred normalization process for the PCTs. For completeness, the targeted cation and the bias-corrected cation compositions were also used to conduct this normalization. As is the usual convention, the common logarithm of the normalized PCT (normalized leachate, NL) for each element of interest was determined and used for comparison. To accomplish this computation, one must

1. Determine the common logarithm of the elemental parts per million (ppm) leachate concentration for each of the triplicates and each of the elements of interest (these values are provided in Table F2 of Appendix F),

2. Average the common logarithms over the triplicates for each element of interest, and then

Normalize Using Measured Composition (preferred method)

3. Subtract a quantity equal to 1 plus the common logarithm of the average cation measured concentration (expressed as a weight percent of the glass) from the average computed in step 2 .

Or Normalize Using Target Composition

3. Subtract a quantity equal to 1 plus the common logarithm of the target cation concentration (expressed as a weight percent of the glass) from the average computed in step 2. 
Or Normalize Using Measured Bias-Corrected Composition

3. Subtract a quantity equal to 1 plus the common logarithm of the measured bias-corrected cation concentration (expressed as a weight percent of the glass) from the average computed in step 2.

Exhibit F7 in Appendix F provides scatter plots for these results and offers an opportunity to investigate into the consistency of the leaching across the elements for the glasses of this study. All normalizations of the PCTs (i.e., those generated using the targeted, measured, and biascorrected compositional views) are represented in these plots. A plot encompassing all of the compositional views is presented at the beginning of the exhibit.

Consistency in the leaching across the elements (i.e., congruent dissolution) is typically demonstrated by a high degree of linear correlation among the values for pairs of these elements. A high degree of correlation is seen for these data for most of the pairs of the elements; the smallest correlation (91.7\%) among the individual compositional views is between $\mathrm{Na}$ and $\mathrm{Li}$ for the measured data.

Table 6-10 summarizes the normalized PCTs for the glasses of this study. The results are by glass identifier. Results for both heat treatments for each of the study glasses as well as results for the two standards, ARM and EA, are shown in this table.

For the VIS glasses, the normalized boron release values (NL [B] g/L) range from $\sim 0.9 \mathrm{~g} / \mathrm{L}$ (VIS1 ; the most durable glass) to $\sim 1.7 \mathrm{~g} / \mathrm{L}$ (VIS-6; the least durable glass). The general trend in the data suggests that as WL increases, durability gradually decreases. This measured trend agrees well with model predictions (see Appendix A). It is noted that the lowest durability glass is still roughly an order of magnitude more durable (as measured by the PCT) than the EA glass (reported value of $16.695 \mathrm{~g} / \mathrm{L}$ by Jantzen et al. 1993).

\subsubsection{Predicted versus Measured PCTs}

Exhibit F8 in Appendix F provides plots of the DWPF models that relate the logarithm of the normalized PCT (for each element of interest) to a linear function of a free energy of hydration term $\left(\Delta \mathrm{G}_{\mathrm{p}}, \mathrm{kcal} / 100 \mathrm{~g}\right.$ glass) derived from all of the glass compositional views (Jantzen et al. 1995). Prediction limits (at a 95\% confidence) for an individual PCT result are also plotted along with the linear fit. Notice that all of the study glasses are predictable and acceptable - consistent with the observation by Lorier et al. (2003). 
Table 6-10. PCT Results for VIS Study Glasses.

\begin{tabular}{|c|c|c|c|c|c|c|c|c|c|c|}
\hline $\begin{array}{l}\text { Glass } \\
\text { ID }\end{array}$ & $\begin{array}{c}\text { Heat } \\
\text { Treatment }\end{array}$ & Composition & $\begin{array}{c}\log N L \\
{[B(g / L)]}\end{array}$ & $\begin{array}{c}\log \mathrm{NL} \\
{[\mathrm{Li}(\mathrm{g} / \mathrm{L})]}\end{array}$ & $\begin{array}{c}\log \mathbf{N L} \\
{[\mathrm{Na}(\mathrm{g} / \mathrm{L})]}\end{array}$ & $\begin{array}{c}\log \mathbf{N L} \\
{[\mathrm{Si}(\mathrm{g} / \mathrm{L})]}\end{array}$ & $\begin{array}{c}\mathrm{NL} \\
\mathrm{B}(\mathrm{g} / \mathrm{L})\end{array}$ & $\begin{array}{c}\mathrm{NL} \\
\mathrm{Li}(\mathrm{g} / \mathrm{L})\end{array}$ & \begin{tabular}{|c|}
$\mathrm{NL}$ \\
$\mathrm{Na}(\mathrm{g} / \mathrm{L})$
\end{tabular} & $\begin{array}{c}\mathrm{NL} \\
\mathrm{Si}(\mathrm{g} / \mathrm{L})\end{array}$ \\
\hline ARM & - & Jantzen et al. 1995 & -0.1765 & -0.1581 & -0.2071 & -0.5030 & 0.67 & 0.69 & 0.62 & 0.31 \\
\hline EA & - & Jantzen et al. 1995 & 1.2410 & 0.9627 & 1.1278 & 0.5796 & 17.42 & 9.18 & 13.42 & 3.80 \\
\hline VIS-1 & quenched & measured & -0.0445 & -0.0037 & 0.0019 & -0.2127 & 0.90 & 0.99 & 1.00 & 0.61 \\
\hline VIS-1 & ccc & measured & -0.0145 & 0.0219 & -0.0130 & -0.1968 & 0.97 & 1.05 & 0.97 & 0.64 \\
\hline VIS-1 & quenched & measured bc & -0.0334 & -0.0112 & 0.0088 & -0.2043 & 0.93 & 0.97 & 1.02 & 0.62 \\
\hline VIS-1 & ccc & measured bc & -0.0034 & 0.0144 & -0.0061 & -0.1884 & 0.99 & 1.03 & 0.99 & 0.65 \\
\hline VIS-1 & quenched & targeted & -0.0400 & -0.0068 & 0.0010 & -0.2171 & 0.91 & 0.98 & 1.00 & 0.61 \\
\hline VIS-1 & $\mathrm{ccc}$ & targeted & -0.0099 & 0.0188 & -0.0139 & -0.2012 & 0.98 & 1.04 & 0.97 & 0.63 \\
\hline VIS-2 & quenched & measured & -0.0110 & -0.0040 & 0.0211 & -0.1990 & 0.98 & 0.99 & 1.05 & 0.63 \\
\hline VIS-2 & $\mathrm{ccc}$ & measured & -0.0219 & 0.0104 & -0.0064 & -0.1956 & 0.95 & 1.02 & 0.99 & 0.64 \\
\hline VIS-2 & quenched & measured bc & 0.0001 & -0.0116 & 0.0280 & -0.1906 & 1.00 & 0.97 & 1.07 & 0.64 \\
\hline VIS-2 & $\mathrm{ccc}$ & measured bc & -0.0108 & 0.0028 & 0.0006 & -0.1872 & 0.98 & 1.01 & 1.00 & 0.65 \\
\hline VIS-2 & quenched & targeted & -0.0051 & -0.0031 & 0.0233 & -0.2081 & 0.99 & 0.99 & 1.06 & 0.62 \\
\hline VIS-2 & ccc & targeted & -0.0160 & 0.0113 & -0.0042 & -0.2047 & 0.96 & 1.03 & 0.99 & 0.62 \\
\hline VIS-3 & quenched & measured & 0.0543 & 0.0262 & 0.0433 & -0.1937 & 1.13 & 1.06 & 1.10 & 0.64 \\
\hline VIS-3 & $\mathrm{ccc}$ & measured & 0.0392 & 0.0215 & 0.0168 & -0.1974 & 1.09 & 1.05 & 1.04 & 0.63 \\
\hline VIS-3 & quenched & measured bc & 0.0439 & 0.0158 & 0.0502 & -0.1853 & 1.11 & 1.04 & 1.12 & 0.65 \\
\hline VIS-3 & $\mathrm{ccc}$ & measured bc & 0.0288 & 0.0111 & 0.0238 & -0.1890 & 1.07 & 1.03 & 1.06 & 0.65 \\
\hline VIS-3 & quenched & targeted & 0.0236 & 0.0226 & 0.0495 & -0.1914 & 1.06 & 1.05 & 1.12 & 0.64 \\
\hline VIS-3 & ccc & targeted & 0.0085 & 0.0178 & 0.0231 & -0.1950 & 1.02 & 1.04 & 1.05 & 0.64 \\
\hline VIS-4 & quenched & measured & 0.0677 & 0.0377 & 0.0692 & -0.1724 & 1.17 & 1.09 & 1.17 & 0.67 \\
\hline VIS-4 & ccc & measured & 0.0700 & 0.0636 & 0.0538 & -0.1573 & 1.17 & 1.16 & 1.13 & 0.70 \\
\hline VIS-4 & quenched & measured bc & 0.0573 & 0.0273 & 0.0658 & -0.1616 & 1.14 & 1.06 & 1.16 & 0.69 \\
\hline VIS-4 & ccc & measured bc & 0.0596 & 0.0532 & 0.0504 & -0.1465 & 1.15 & 1.13 & 1.12 & 0.71 \\
\hline VIS-4 & quenched & targeted & 0.0620 & 0.0324 & 0.0664 & -0.1790 & 1.15 & 1.08 & 1.17 & 0.66 \\
\hline VIS-4 & $\mathrm{ccc}$ & targeted & 0.0643 & 0.0583 & 0.0510 & -0.1638 & 1.16 & 1.14 & 1.12 & 0.69 \\
\hline VIS-5 & quenched & measured & 0.1292 & 0.0758 & 0.1014 & -0.1519 & 1.35 & 1.19 & 1.26 & 0.70 \\
\hline VIS-5 & $\mathrm{ccc}$ & measured & 0.1560 & 0.1215 & 0.0941 & -0.1189 & 1.43 & 1.32 & 1.24 & 0.76 \\
\hline VIS-5 & quenched & measured bc & 0.1189 & 0.0654 & 0.1084 & -0.1435 & 1.31 & 1.16 & 1.28 & 0.72 \\
\hline VIS-5 & ccc & measured bc & 0.1457 & 0.1110 & 0.1010 & -0.1105 & 1.40 & 1.29 & 1.26 & 0.78 \\
\hline VIS-5 & quenched & targeted & 0.1089 & 0.0759 & 0.1165 & -0.1517 & 1.28 & 1.19 & 1.31 & 0.71 \\
\hline VIS-5 & $\mathrm{ccc}$ & targeted & 0.1357 & 0.1216 & 0.1091 & -0.1188 & 1.37 & 1.32 & 1.29 & 0.76 \\
\hline VIS-6 & quenched & measured & 0.2065 & 0.1297 & 0.1898 & -0.1011 & 1.61 & 1.35 & 1.55 & 0.79 \\
\hline VIS-6 & $\mathrm{ccc}$ & measured & 0.2285 & 0.2087 & 0.1929 & -0.0628 & 1.69 & 1.62 & 1.56 & 0.87 \\
\hline VIS-6 & quenched & measured bc & 0.2176 & 0.1221 & 0.1968 & -0.0927 & 1.65 & 1.32 & 1.57 & 0.81 \\
\hline VIS-6 & $\mathrm{ccc}$ & measured bc & 0.2395 & 0.2011 & 0.1999 & -0.0545 & 1.74 & 1.59 & 1.58 & 0.88 \\
\hline VIS-6 & quenched & targeted & 0.2155 & 0.1341 & 0.1902 & -0.1020 & 1.64 & 1.36 & 1.55 & 0.79 \\
\hline VIS-6 & ccc & targeted & 0.2374 & 0.2132 & 0.1933 & -0.0638 & 1.73 & 1.63 & 1.56 & 0.86 \\
\hline
\end{tabular}




\subsection{SUMMARY}

In this report, data are provided to DWPF from which engineering judgments can be made with respect to a possible link between glass viscosity and its potential impacts on critical processing operations (such as melter and/or pour stream stability). High temperature viscosity data are generated for the Frit 418 - SB3 system as a function of waste loading (from 30 to $45 \%$ ) and compared to similar data for other systems that have been (or are currently being) processed through the DWPF melter. The data are presented in various formats to potentially align the viscosity data with physical observations at various points in the melter system or critical DWPF processing unit operations in order to develop working solutions. The following conclusions are drawn from the data:

(1) The data trends suggest that as WL increases in the Frit 418 - SB3 system the viscosity decreases. The $\eta_{1150^{\circ} \mathrm{C}}$ values range from 42.33 to 24.77 Poise at $30 \%$ and $45 \% \mathrm{WL}$, respectively. This trend is consistent with PCCS model predictions

(2) In addition, as temperatures decrease, the viscosity increases (non-linearly) for a fixed WL. The non-linear relation between viscosity and temperature observed in the Frit 418 - SB3 system is typical of inorganic glasses. The data presented demonstrated that for a fixed change in temperature $(\Delta \mathrm{T})$, the change in viscosity $(\Delta \eta)$ becomes more dramatic in the lower temperature range. Therefore, when one discusses the impacts of glass viscosity on melt rate and/or pour stream stability the viscosity response of the glass could be markedly different depending on the magnitude of the $\Delta \mathrm{T}$ as well as the temperature range over which the change occurs. Therefore, it is critical to understanding not only the dependence of the viscosity versus temperature curve but also the temperature regimes in which links to physical effects should be made.

(3) Although the trends in the viscosity versus WL data are relatively consistent with PCCS model prediction, a potentially significant difference is observed when magnitudes were compared. For example, the PCCS predictions for VIS-01 (30\% WL) are between $\sim 14-$ 18 Poise higher than the Fulcher fit predictions based on measured viscosity data. This apparent bias in the PCCS model decreases as WLs increase or viscosity decrease to the point of being within experimental error (or at least of no practical concern) at $45 \% \mathrm{WL}$. This bias has been observed in other DWPF glass systems (Peeler et al. 2003).

(4) Given the measured viscosity data for the VIS glasses were taken over a limited but higher temperature interval $\left(1000-1200^{\circ} \mathrm{C}\right)$, the "high temperature" data were approximately by a linear fit with the slope providing insight into potential activation energy differences as a function of WL. Although a formal activation energy was not calculated, the slopes of the six VIS glasses do not show any major deviation suggesting very little if any difference in activation energy among the systems as a function of WL.

The report attempts to provide some insight into a physical interpretation of the data from a DWPF perspective. The theories presented are certainly not an all inclusive list and the order in which they are presented does not imply a ranking, probability, or likelihood that the proposed theory is even plausible. The intent of this discussion is to provide a forum in which the viscosity data can be discussed in relation to possible mechanisms which potentially could help lead to a workable solution as a higher overall attainment is strived for during processing of the current or future sludge batches. 
In simplistic terms and assuming all other factors equal, lower viscosity glasses would be more susceptible to "movement" for a given applied force. Therefore, as WLs increase within a specific system or a frit is used that reduces viscosity as compared to other systems (e.g., Frit 418 versus Frit 202), pressure spikes (possibly resulting from cold cap reactions or steam) that translates into the pour spout could adversely affect the stability of the pour stream to a higher degree. If true then as one reduces the viscosity of the glass, more frequent pour stream instability events would be observed assuming the high melt rate feed continues to generate a similar frequency and magnitude of pressure perturbations in the vapor space. In general, this is in line with recent DWPF observations - prompting the decision to utilize Frit 202 with SB3 and consideration of establishing a higher lower viscosity limit for future frit development efforts. It should also be noted that although a positive outcome may be expected from a pour stream stability perspective as viscosity is increased, other factors (such as melt rate) may experience a negative impact.

From a melt rate perspective, glass formulation efforts are pushed toward maximizing the alkali content of the glass which based on previous testing has shown to be highly correlated to melt rate (Peeler et al. 2001, Smith and Jones 2003, Smith et al. 2003). This compositional direction will tend to lower the overall glass viscosity and the resulting increase in melt rate may be attributed to differences in cold cap reactions and/or increased convection currents within the molten glass pool which ultimately sweeps or replenishes "hot" glass to the cold cap / melt pool interface expediting conversion of the incoming feed to glass. However, the down stream effects of a low viscosity system may adversely impact pour stream stability to such a degree that overall attainment is lowered (even though melt rate is high). Therefore, the challenge will be to find a viscosity (or viscosity range) that strikes a balance among melter stability, melt rate, and attainment that allows DWPF to meet (or exceed) processing expectations. This latter statement does not include any physical changes that have been or could be made to the melter (e.g., the glass pump may be able to compensate for a lower melt rate system while maintaining adequate pour stream stability characteristics). 


\subsection{RECOMMENDATIONS}

Based on the results of this study, the following recommendations are made:

(1) Obtain melt rate data for the Frit 320 - SB3 system to assess the potential impacts of lower viscosity on melt rate.

This recommendation parallels the incentive for implementation of the proposed durability limits as demonstrated by Peeler et al. (2004c). Based on that recommendation, a SMRF test has been proposed based on the Frit 320 - SB3 system. Although no indication of melter stability or pour stream stability can be assessed using the current laboratory systems, the results could provide insight into the possible gains in melt rate if Frit 320 were implemented. If higher melt rates (relative to Frit 418) are observed, this would continue the trend observed between melt rate and total alkali content. If there is no change in melt rate (or even a decline), this data point would provide insight into a potential maximum alkali content above which further additions do not enhance melt rate for the SB3 system.

(2) Assess the potential bias in the current viscosity model as a function of WL.

If modifications to the lower viscosity limit are further considered, an assessment of the potential bias in the viscosity model should be addressed. In fact, a formal measurement of the system of interest may be needed as part of a variability study if this bias can not be addressed.

(3) Feedback from DWPF operations is requested with respect to the potential impacts of viscosity on melt rate, melter stability and/or pour stream stability leading to overall attainment. This feedback should be used to establish new processing limits (if needed) to guide future frit development efforts. 
WSRC-TR-2004-00429

Revision 0

This page intentionally left blank. 


\subsection{REFERENCES}

ASTM 2002. Standard Test Methods for Determining Chemical Durability of Nuclear Waste Glasses: The Product Consistency Test (PCT), ASTM C-1285-2002.

Brown KG, CM Jantzen, and G Ritzhaupt. 2001. Relating Liquidus Temperature to Composition for Defense Waste Processing Facility (DWPF) Process Control, WSRC-TR-2001-00520, Westinghouse Savannah River Company, Aiken, South Carolina.

Brown, KG, RL Postles, and TB Edwards. 2002. SME Acceptability Determination for DWPF Process Control, WSRC-TR-95-0364, Revision 4, Westinghouse Savannah River Company, Aiken, South Carolina.

Edwards, TB, DK Peeler, and SL Marra. 2003. Revisiting the Prediction Limits for Acceptable Durability, WSRC-TR-2003-00510, Revision 0, Westinghouse Savannah River Company, Aiken, South Carolina.

Jantzen CM, NE Bibler, DC Beam, CL Crawford, and MA Pickett. 1993. Characterization of the DWPF Environmental Assessment (EA) Glass Standard Reference Material (U), WSRC-TR92-346, Revision 1, Westinghouse Savannah River Company, Aiken, SC.

Jantzen, CM, JB Pickett, KG Brown, TB Edwards, and DC Beam. 1995. Process/Product Models for the Defense Waste Processing Facility (DWPF): Part I. Predicting Glass Durability from Composition Using a Thermodynamic Hydration Energy Reaction Model (THERMO), WSRC-TR-93-672, Revision 1, Volume 1, Westinghouse Savannah River Company, Aiken, South Carolina.

Lambert, DP, TH Lorier, DK Peeler, and ME Stone. 2001. Melt Rate Improvement for DWPF MB3: Summary and Recommendations, WSRC-TR-2001-00148, Westinghouse Savannah River Company, Aiken, South Carolina.

Lorier, TH, TB Edwards, IA Reamer, DR Best, and DK Peeler. 2003. SB3 Phase 2 Variability Study: The Impact of REDOX on Durability for the Frit 418 - SB2/3 System, WSRC-TR-200300539, Revision 0, Westinghouse Savannah River Company, Aiken, South Carolina.

Marra SL, and CM Jantzen. 1993. Characterization of Projected DWPF Glasses Heat Treated to Simulate Canister Centerline Cooling (U), WSRC-TR-92-142, Revision 1, Westinghouse Savannah River Company, Aiken, South Carolina.

Miller, DH. 2004. Slurry-Fed Melt Rate Furnace Testing of SB3/Frit 202 with and Without NaOH Addition, SRNL-GPD-2004-00013, Westinghouse Savannah River Company, Aiken, South Carolina.

Peeler, DK, TH Lorier, DF Bickford, DC Witt, TB Edwards, KG Brown, IA Reamer, RJ Workman, and JD Vienna. 2001. Melt Rate Improvement for DWPF MB3: Frit Development and Model Assessment, WSRC-TR-2001-00131, Revision 0, Westinghouse Savannah River Company, Aiken, South Carolina.

Peeler, DK and TB Edwards. 2002. Frit Development for Sludge Batch 3, WSRC-TR-200200491, Revision 0, Westinghouse Savannah River Company, Aiken, South Carolina. 
Peeler, DK and TB Edwards. 2003a. Projected Operating Windows for Various Sludge Batch 2/3 Blends: A Progression from a PAR to a MAR Assessment, WSRC-TR-2003-00509, Revision 0, Westinghouse Savannah River Company, Aiken, South Carolina.

Peeler, DK and TB Edwards. 2003b. The Potential Impact of Alternative Durability Options on the DWPF Process Control System, SRT-GDP-2003-00104, Revision 0, Westinghouse Savannah River Company, Aiken, South Carolina.

Peeler, DK, DR Best, TB Edwards, DM Missimer, and AR Jurgensen. 2003. Crystallization Potential and Viscosity Assessments for Frit 320/ Sludge Batch 2 Glasses, SRT-GPD-200300124, Revision 0, Westinghouse Savannah River Company, Aiken South Carolina.

Peeler DK, TB Edwards, and AS Taylor. 2004a. The Impact of the Proposed $\Delta G_{P}$ Limits on Glass Formulation Efforts: Part I. Model-Based Assessments, WSRC-TR-2004-00203, Revision 0, Westinghouse Savannah River Company, Aiken South Carolina.

Peeler, DK, TB Edwards, and AS Taylor. 2004b. The Impact of Proposed $\Delta G_{P}$ Limits on Glass Formulation Efforts: Part II. Experimental Results, WSRC-TR-2004-00348, Revision 0, Westinghouse Savannah River Company, Aiken South Carolina.

Savannah River National Laboratory (SRNL). 2002a. "Glass Batching," SRTC Procedure Manual, L29, ITS-0001, Westinghouse Savannah River Company, Aiken, South Carolina.

Savannah River National Laboratory (SRNL). 2002b. "Glass Melting," SRTC Procedure Manual, L29, ITS-0003, Westinghouse Savannah River Company, Aiken, South Carolina.

Schumacher, RF and DK Peeler. 1998. Establishment of Harrop, High Temperature Viscometer, WSRC-RP-98-00737, Revision 0, Westinghouse Savannah River Company, Aiken, South Carolina.

Smith, ME and TM Jones. 2003. DWPF Melt Rate Testing for SB2/Frit 320 (31, 35, and 40\% Waste Loaded, WSRC-TR-2003-00512, Westinghouse Savannah River Company, Aiken, South Carolina.

Smith, ME, TH Lorier, and TM Jones. 2003. SMRF and MRF DWPF Melt Rate Testing for SB2/3 (Case 6b-250 Canisters), WSRC-TR-2003-00466, Revision 0, Westinghouse Savannah River Company, Aiken, South Carolina.

Stone, ME and JE Josephs, Melt Rate Improvement for DWPF MB3: Melt Rate Furnace Testing, WSRC-TR-2001-00146, Revision 0, Westinghouse Savannah River Company, Aiken South Carolina. 


\section{APPENDIX A}

\section{Frit 418 - SB3 MAR Assessments}


WSRC-TR-2004-00429

Revision 0

Table A1. Critical Glass Property Predictions and Composition Information Used for the Frit 418 - SB3 MAR Assessments.

\begin{tabular}{|c|c|c|c|c|c|c|c|c|c|}
\hline $\begin{array}{l}\text { WL } \\
(\%)\end{array}$ & $\begin{array}{c}\mathbf{L i} \Delta \mathbf{G p} \\
\text { MAR }\end{array}$ & $\begin{array}{l}\text { B } \Delta \text { Gp } \\
\text { Value }\end{array}$ & $\begin{array}{c}T_{L} \text { Pred } \\
\left({ }^{\circ} \mathrm{C}\right)\end{array}$ & $\begin{array}{c}\text { T }_{L} \text { MAR } \\
\left({ }^{\circ} \mathrm{C}\right)\end{array}$ & $\begin{array}{c}\text { Visc Pred } \\
\text { (Poise) }\end{array}$ & $\begin{array}{c}\mathrm{Al}_{2} \mathrm{O}_{3} \\
\mathrm{wt} \%\end{array}$ & $\begin{array}{l}\mathrm{R}_{2} \mathrm{O} \\
\mathrm{wt} \%\end{array}$ & $\begin{array}{l}\mathbf{R}_{\mathbf{2}} \mathbf{O} \\
\text { MAR }\end{array}$ & MAR Status \\
\hline 25 & -12.3950 & -10.5402 & 756.73 & 994.42 & 72.89 & 3.83 & 17.56 & 18.64 & - \\
\hline 26 & -12.3950 & -10.5872 & 771.86 & 996.70 & 70.14 & 3.98 & 17.62 & 18.64 & - \\
\hline 27 & -12.3950 & -10.6342 & 786.61 & 998.85 & 67.42 & 4.13 & 17.68 & 18.64 & - \\
\hline 28 & -12.3950 & -10.6812 & 801.00 & 1000.88 & 64.74 & 4.29 & 17.75 & 18.64 & - \\
\hline 29 & -12.3950 & -10.7282 & 815.04 & 1002.81 & 62.10 & 4.44 & 17.81 & 18.64 & - \\
\hline 30 & -12.3950 & -10.7751 & 828.76 & 1004.64 & 59.50 & 4.59 & 17.87 & 18.64 & - \\
\hline 31 & -12.3950 & -10.8221 & 842.16 & 1006.37 & 56.94 & 4.75 & 17.93 & 18.64 & - \\
\hline 32 & -12.3950 & -10.8691 & 855.25 & 1008.02 & 54.43 & 4.90 & 17.99 & 18.64 & - \\
\hline 33 & -12.3950 & -10.9161 & 868.06 & 1009.56 & 51.96 & 5.05 & 18.06 & 18.64 & - \\
\hline 34 & -12.3950 & -10.9631 & 880.58 & 1011.02 & 49.53 & 5.21 & 18.12 & 18.64 & - \\
\hline 35 & -12.3950 & -11.0101 & 892.83 & 1012.39 & 47.16 & 5.36 & 18.18 & 18.64 & - \\
\hline 36 & -12.3950 & -11.0571 & 904.82 & 1013.66 & 44.83 & 5.51 & 18.24 & 18.63 & - \\
\hline 37 & -12.3950 & -11.1041 & 916.56 & 1014.83 & 42.56 & 5.66 & 18.31 & 18.63 & - \\
\hline 38 & -12.3950 & -11.1511 & 928.06 & 1015.89 & 40.34 & 5.82 & 18.37 & 18.63 & - \\
\hline 39 & -12.3950 & -11.1981 & 939.32 & 1016.85 & 38.17 & 5.97 & 18.43 & 18.62 & - \\
\hline 40 & -12.3950 & -11.2451 & 950.35 & 1017.55 & 36.05 & 6.12 & 18.49 & 18.62 & - \\
\hline 41 & -12.3950 & -11.2921 & 961.17 & 1017.92 & 33.99 & 6.28 & 18.56 & 18.62 & - \\
\hline 42 & -12.3950 & -11.3391 & 971.77 & 1018.19 & 31.99 & 6.43 & 18.62 & 18.62 & - \\
\hline 43 & -12.3950 & -11.3861 & 982.16 & 1018.34 & 30.05 & 6.58 & 18.68 & 18.61 & - \\
\hline 44 & -12.3950 & -11.4330 & 992.36 & 1018.39 & 28.16 & 6.74 & 18.74 & 18.61 & - \\
\hline 45 & -12.3950 & -11.4800 & 1002.36 & 1018.33 & 26.34 & 6.89 & 18.80 & 18.61 & - \\
\hline 46 & -12.3950 & -11.5270 & 1012.17 & 1018.16 & 24.58 & 7.04 & 18.87 & 18.60 & - \\
\hline 47 & -12.3948 & -11.5740 & 1021.80 & 1017.91 & 22.88 & 7.20 & 18.93 & 18.60 & low $\eta$ \\
\hline 48 & -12.3919 & -11.6210 & 1031.26 & 1017.56 & 21.24 & 7.35 & 18.99 & 18.60 & low $\eta$ \\
\hline 49 & -12.3890 & -11.6680 & 1040.54 & 1017.14 & 19.67 & 7.50 & 19.05 & 18.60 & low $\eta$ \\
\hline 50 & -12.3860 & -11.7150 & 1049.65 & 1016.66 & 18.16 & 7.66 & 19.12 & 18.59 & low $\eta$ \\
\hline 51 & -12.3831 & -11.7620 & 1058.60 & 1016.11 & 16.72 & 7.81 & 19.18 & 18.59 & low $\eta$ \\
\hline 52 & -12.3801 & -11.8090 & 1067.40 & 1015.52 & 15.34 & 7.96 & 19.24 & 18.59 & low $\eta$ \\
\hline 53 & -12.3772 & -11.8560 & 1076.04 & 1014.88 & 14.03 & 8.11 & 19.30 & 18.58 & low $\eta$ \\
\hline 54 & -12.3743 & -11.9030 & 1084.53 & 1014.21 & 12.79 & 8.27 & 19.37 & 18.58 & low $\eta$ \\
\hline 55 & -12.3713 & -11.9500 & 1092.87 & 1013.51 & 11.61 & 8.42 & 19.43 & 18.58 & low $\eta$ \\
\hline 56 & -12.3684 & -11.9970 & 1101.07 & 1012.79 & 10.50 & 8.57 & 19.49 & 18.57 & low $\eta$ \\
\hline 57 & -12.3654 & -12.0440 & 1109.14 & 1012.04 & 9.46 & 8.73 & 19.55 & 18.57 & low $\eta$ \\
\hline 58 & -12.3625 & -12.0909 & 1117.06 & 1011.28 & 8.48 & 8.88 & 19.61 & 18.57 & $\mathrm{~T}_{\mathrm{L}} \quad$ low $\eta$ \\
\hline 59 & -12.3595 & -12.1379 & 1124.86 & 1010.50 & 7.56 & 9.03 & 19.68 & 18.57 & $\mathrm{~T}_{\mathrm{L}} \quad$ low $\eta$ \\
\hline 60 & -12.3565 & -12.1849 & 1132.53 & 1009.70 & 6.71 & 9.19 & 19.74 & 18.56 & $\mathrm{~T}_{\mathrm{L}} \quad$ low $\eta$ \\
\hline
\end{tabular}




\section{APPENDIX B}

\section{Chemical Composition Analytical Plan}




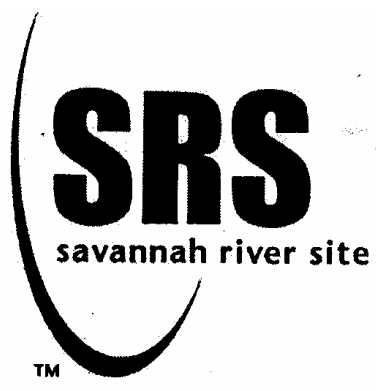

WESTINGHOUSE SAVANNAH RIVER COMPANY INTEROFFICE MEMORANDUM

SRT-SCS-2004-00017

April 23, 2004

To:

D. K. Peeler, 999-W

cc:

R. A. Baker, 773-42A

D. R. Best, 786-1A (wo)

S. L. Marra, 999-W (es)

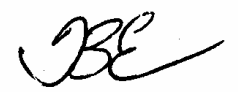

From: $\quad$ T. B. Edwards, 773-42A (5-5148)

Statistical Consulting Section
I. A. Reamer, 999-1W

P. A. Toole, 786-1A (wo)

R. C. Tuckfield, 773-42A

R. J. Workman, 999-1W

wo - without glass identifiers

es - executive summary only

Radenerakes

R. A. Baker, Technical Reviewer

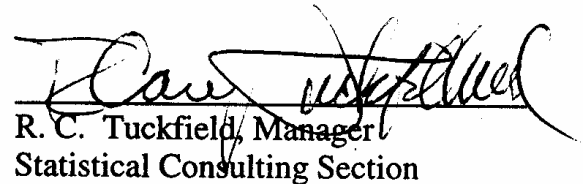

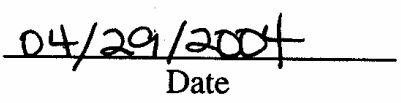

$\frac{4 / 29 / 04}{\text { Date }}$

\section{An Analytical Plan for Measuring the Chemical Compositions of the ADT and VIS Study Glasses (U)}




\subsection{Executive Summary}

This memorandum has been prepared to assist two glass studies that are being conducted by the Savannah River Technology Center (SRTC) in support of the accelerated mission at the Defense Waste Processing Facility (DWPF). One study is investigating the relationship between viscosity and waste loading for the Sludge Batch 3 (SB3)/Frit 418 glass system, while the second study is investigating alternative durability options for the DWPF. Glasses are being batched and fabricated for each of these studies: 6 glasses (designated by a "VIS" prefix for VIScosity) for the first study and 8 glasses (designated by an "ADT" prefix for Alternative Durability Task) for the second study. The chemical compositions of these glasses are to be determined by the Savannah River Technology Center - Mobile Laboratory (SRTC-ML). This memorandum provides an analytical plan to direct and support the measurement of the chemical compositions for both sets of study glasses.

\subsection{Introduction}

This memorandum has been prepared to assist two glass studies that are being conducted by the Savannah River Technology Center (SRTC) in support of the accelerated mission at the Defense Waste Processing Facility (DWPF). One study is investigating the relationship between viscosity and waste loading for the Sludge Batch 3 (SB3)/Frit 418 glass system, while the second study is investigating alternative durability options for the DWPF. Glasses are being batched and fabricated for each of these studies: 6 glasses (designated by a "VIS" prefix for VIScosity) for the first study and 8 glasses (designated by an "ADT" prefix for Alternative Durability Task) for the second study. The chemical compositions of these glasses are to be determined by the Savannah River Technology Center - Mobile Laboratory (SRTC-ML). This memorandum provides an analytical plan to direct and support the measurement of the chemical compositions for both sets of study glasses.

\subsection{Analytical Plan}

The analytical procedures used by the SRTC-ML to determine cation concentrations for a glass sample include steps for sample preparation and for instrument calibration. Each glass is to be prepared in duplicate by each of two dissolution methods: lithium metaborate (LM) and sodium peroxide fusion $(\mathrm{PF})$.

The primary measurements of interest are to be acquired as follows. The samples prepared by $\mathrm{LM}$ are to be measured for aluminum (Al), barium $(\mathrm{Ba})$, calcium $(\mathrm{Ca})$, cerium $(\mathrm{Ce})$, chromium $(\mathrm{Cr})$, copper $(\mathrm{Cu})$, iron $(\mathrm{Fe})$, potassium $(\mathrm{K})$, lanthanum $(\mathrm{La})$, magnesium $(\mathrm{Mg})$, manganese $(\mathrm{Mn})$, sodium $(\mathrm{Na})$, nickel $(\mathrm{Ni})$, lead $(\mathrm{Pb})$, thorium $(\mathrm{Th})$, titanium $(\mathrm{Ti})$, uranium $(\mathrm{U})$, zinc $(\mathrm{Zn})$, and zirconium (Zr) concentrations. Samples prepared by PF are to be measured for boron (B), lithium (Li), and silicon ( $\mathrm{Si}$ ). Samples dissolved by both preparation methods are to be measured using Inductively Coupled Plasma - Atomic Emission Spectrometry (ICP-AES). It should be noted that some of these elements are minor components that may be near detection limits for most, if not all, of the study glasses. If the measurements for an element are determined using samples prepared in a manner that differs from the above description, these changes should be noted as part of the information provided by the SRTC-ML in reporting the results from this study.

As stated above, each glass sample submitted to the SRTC-ML will be prepared in duplicate by the LM and PF dissolution methods. Every prepared sample will be read twice by ICP-AES, with 
the instrument being calibrated before each of these two sets of readings. This will lead to four measurements for each cation of interest for each submitted glass.

Randomizing the preparation steps and blocking and randomizing the measurements for the ICPAES are of primary concern in the development of this analytical plan. The sources of uncertainty for the analytical procedure used by the SRTC-ML to determine the cation concentrations are dominated by the dissolution step in the preparation of the sample and by the calibrations of the ICP-AES.

Samples of standard glasses will be included in the analytical plan to allow performance checks on the instrumentation over the course of the analyses and for potential bias correction.

Specifically, several samples of Waste Compliance Plan (WCP) Batch 1 (BCH) [1] and of a uranium standard glass (Ustd) are included in this analytical plan. The reference compositions of these glasses are provided in Table 1. The standards will be referred to using the short identifiers $\mathrm{BCH}$ and Ustd in the remainder of this memo.

Table 1: Oxide Compositions of WCP Batch 1 (BCH) and the Uranium Standard (Ustd)

\begin{tabular}{|c|c|c|}
\hline Oxide/ & BCH & Ustd \\
\hline Anion & $(w t \%)$ & $(w t \%)$ \\
\hline $\mathrm{Al}_{2} \mathrm{O}_{3}$ & 4.877 & 4.1 \\
\hline $\mathrm{B}_{2} \mathrm{O}_{3}$ & 7.777 & 9.209 \\
\hline $\mathrm{BaO}$ & 0.151 & 0.00 \\
\hline $\mathrm{CaO}$ & 1.220 & 1.301 \\
\hline $\mathrm{CdO}$ & 0.00 & 0.00 \\
\hline $\mathrm{Cl}$ & 0.00 & 0.00 \\
\hline $\mathrm{Cr}_{2} \mathrm{O}_{3}$ & 0.107 & 0.00 \\
\hline $\mathrm{Cs}_{2} \mathrm{O}$ & 0.060 & 0.00 \\
\hline $\mathrm{CuO}$ & 0.399 & 0.00 \\
\hline $\mathrm{F}$ & 0.00 & 0.00 \\
\hline $\mathrm{Fe}_{2} \mathrm{O}_{3}$ & 12.839 & 13.196 \\
\hline $\mathrm{K}_{2} \mathrm{O}$ & 3.327 & 2.999 \\
\hline $\mathrm{Li}_{2} \mathrm{O}$ & 4.429 & 3.057 \\
\hline $\mathrm{MgO}$ & 1.419 & 1.21 \\
\hline $\mathrm{MnO}$ & 1.726 & 2.892 \\
\hline $\mathrm{MoO}_{3}$ & 0.00 & 0.00 \\
\hline $\mathrm{Na}_{2} \mathrm{O}$ & 9.003 & 11.795 \\
\hline $\mathrm{Nd}_{2} \mathrm{O}_{3}$ & 0.147 & 0.00 \\
\hline $\mathrm{NiO}$ & 0.751 & 1.12 \\
\hline $\mathrm{P}_{2} \mathrm{O}_{5}$ & 0.00 & 0.00 \\
\hline $\mathrm{PbO}$ & 0.00 & 0.00 \\
\hline $\mathrm{RuO}_{2}$ & 0.0214 & 0.00 \\
\hline $\mathrm{SiO}_{2}$ & 50.22 & 45.353 \\
\hline $\mathrm{SnO}_{2}$ & 0.00 & 0.00 \\
\hline $\mathrm{SO}_{3}$ & 0.00 & 0.00 \\
\hline $\mathrm{TiO}_{2}$ & 0.677 & 1.049 \\
\hline $\mathrm{U}_{3} \mathrm{O}_{8}$ & 0.00 & 2.406 \\
\hline $\mathrm{ZrO}_{2}$ & 0.098 & 0.00 \\
\hline Sum of Oxides & 99.2484 & 99.687 \\
\hline
\end{tabular}


Table 2 presents identifying codes, va01 through va14, for the 14 glasses for these two studies. The table provides a naming convention that is to be used in analyzing the glasses and reporting the measurements of their compositions. ${ }^{14}$

\section{Table 2: Glass Identifiers to Establish Blind Samples for the SRTC-ML}

\begin{tabular}{|cc|}
\hline Glass & Sample \\
ID & ID \\
VIS-1 & va11 \\
VIS-2 & va05 \\
VIS-3 & va09 \\
VIS-4 & va12 \\
VIS-5 & va01 \\
VIS-6 & va14 \\
ADT-1 & va03 \\
ADT-2 & va13 \\
ADT-3 & va04 \\
ADT-4 & va06 \\
ADT-5 & va08 \\
ADT-6 & va07 \\
ADT-7 & va02 \\
ADT-8 & va10 \\
\hline
\end{tabular}

\subsection{Preparation of the Samples}

Each of the 14 glasses included in this analytical plan is to be prepared in duplicate by the LM and PF dissolution methods. Thus, the total number of prepared glass samples is determined by $14 \cdot 2 \cdot 2=56$, not including the samples of the $\mathrm{BCH}$ and Ustd glass standards that are to be prepared.

Tables $3 \mathrm{a}$ and $3 \mathrm{~b}$ provide blocking and (random) sequencing schema for conducting the preparation steps of the analytical procedures. One block of preparation work is provided for each preparation method to facilitate the scheduling of activities by work shift. The identifier for each of the prepared samples indicates the sample identifier (ID), preparation method, and duplicate number.

14 Renaming these samples helps to ensure that they will be processed as blind samples within the SRTC-ML. Table 2 is not shown in its entirety in the copies going to the SRTC-ML. 
Tables 3a and 3b: Preparation Blocks by Method

Table 3a: LM

(Lithium Metaborate)

Preparation Block

va12LM1

va05LM1

va14LM1

va05LM2

va04LM1

va09LM1

va07LM1

va12LM2

va03LM1

va03LM2

va04LM2

va07LM2

va09LM2

va14LM2

va13LM1

va10LM1

va13LM2

va10LM2

va08LM1

va11LM1

va06LM1

va02LM1

va01LM1

va06LM2

va08LM2

va11LM2

va01LM2

va02LM2
Table 3b: PF

(Peroxide Fusion)

Preparation Block

va05PF1

va13PF1

va05PF2

va01PF1

va08PF1

va07PF1

va01PF2

va03PF1

va08PF2

va09PF1

va14PF1

va12PF1

va07PF2

va03PF2

va13PF2

va09PF2

va06PF1

va12PF2

va04PF1

va14PF2

va11PF1

va10PF1

va04PF2

va02PF1

va10PF2

va06PF2

va11PF2

va02PF2 


\subsection{ICP-AES Calibration Blocks}

The glass samples prepared by the LM and PF dissolution methods are to be analyzed using ICPAES instrumentation calibrated for the particular preparation method. After the initial set of cation concentration measurements, the ICP-AES instrumentation is to be recalibrated and a second set of concentration measurements for the cations determined.

Randomized plans for measuring cation concentrations in the LM-prepared and PF-prepared samples are provided in Tables $4 \mathrm{a}$ and $4 \mathrm{~b}$, respectively. The cations to be measured are specified in the header of each table. In the tables, the sample identifiers for the 14 study glasses have been modified by the addition of a suffix (a " 1 " or a " 2 ") to indicate whether the measurement was made during the first or second (respectively) ICP-AES calibration group. The identifiers for the $\mathrm{BCH}$ and Ustd samples have been further modified to indicate that each of these prepared samples is to be read 3 times (mirrored in the corresponding suffix of 1,2, or 3) per calibration block.

Tables 4a and 4b: ICP-AES Blocks \& Calibration Groups By Preparation Method

Table 4a: LM Preparation Method (Used to Measure Elemental Al, Ba, Ca, Ce, $\mathrm{Cr}, \mathrm{Cu}, \mathrm{Fe}, \mathrm{K}, \mathrm{La}, \mathrm{Mg}, \mathrm{Mn}, \mathrm{Na}, \mathrm{Ni}, \mathrm{Pb}, \mathrm{Th}, \mathrm{Ti}$, $\mathrm{U}, \mathbf{Z n}, \& \mathbf{Z r})$

\begin{tabular}{|llll|}
\hline Calibration & Calibration & Calibration & Calibration \\
1-1 & $\mathbf{1 - 2}$ & $\mathbf{2 - 1}$ & $\mathbf{2 - 2}$ \\
bchLM111 & bchLM121 & bchLM211 & bchLM221 \\
ustdLM111 & ustdLM121 & ustdLM211 & ustdLM221 \\
va14LM11 & va02LM22 & va12LM11 & va12LM12 \\
va02LM21 & va01LM12 & va13LM11 & va12LM22 \\
va05LM11 & va09LM12 & va03LM11 & va10LM12 \\
va07LM11 & va07LM22 & va04LM11 & va03LM12 \\
va09LM21 & va14LM22 & va06LM11 & va04LM12 \\
va11LM21 & va02LM12 & va06LM21 & va10LM22 \\
va05LM21 & va11LM22 & va08LM11 & va13LM12 \\
bchLM112 & bchLM122 & bchLM212 & bchLM222 \\
ustdLM112 & ustdLM122 & ustdLM212 & ustdLM222 \\
va07LM21 & va14LM12 & va10LM11 & va13LM22 \\
va11LM11 & va05LM12 & va03LM21 & va06LM22 \\
va01LM21 & va09LM22 & va10LM21 & va04LM22 \\
va09LM11 & va01LM22 & va08LM21 & va08LM12 \\
va01LM11 & va05LM22 & va04LM21 & va03LM22 \\
va02LM11 & va07LM12 & va12LM21 & va08LM22 \\
va14LM21 & va11LM12 & va13LM21 & va06LM12 \\
ustdLM113 & ustdLM123 & ustdLM213 & ustdLM223 \\
bchLM113 & bchLM123 & bchLM213 & bchLM223 \\
\hline
\end{tabular}

Table 4b: PF Preparation Method (Used to Measure Elemental B, Li, \& Si)

\begin{tabular}{|cccc|}
\hline Calibration & Calibration & Calibration & Calibration \\
1-1 & $\mathbf{1 - 2}$ & $\mathbf{2 - 1}$ & $\mathbf{2 - 2}$ \\
bchPF111 & bchPF121 & bchPF211 & bchPF221 \\
ustdPF111 & ustdPF121 & ustdPF211 & ustdPF221 \\
va04PF11 & va12PF12 & va02PF11 & va11PF22 \\
va12PF11 & va01PF22 & va13PF21 & va05PF12 \\
va06PF21 & va12PF22 & va11PF21 & va14PF22 \\
va04PF21 & va01PF12 & va08PF21 & va08PF22 \\
va09PF11 & va04PF22 & va05PF21 & va13PF12 \\
va12PF21 & va06PF12 & va03PF21 & va03PF12 \\
va01PF11 & va04PF12 & va14PF11 & va02PF22 \\
bchPF112 & bchPF122 & bchPF212 & bchPF222 \\
ustdPF112 & ustdPF122 & ustdPF212 & ustdPF222 \\
va07PF11 & va07PF22 & va08PF11 & va03PF22 \\
va07PF21 & va06PF22 & va02PF21 & va05PF22 \\
va10PF11 & va10PF12 & va14PF21 & va13PF22 \\
va06PF11 & va07PF12 & va05PF11 & va14PF12 \\
va09PF21 & va09PF12 & va11PF11 & va11PF12 \\
va10PF21 & va09PF22 & va13PF11 & va08PF12 \\
va01PF21 & va10PF22 & va03PF11 & va02PF12 \\
ustdPF113 & ustdPF123 & ustdPF213 & ustdPF223 \\
bchPF113 & bchPF123 & bchPF213 & bchPF223 \\
\hline
\end{tabular}




\subsection{Concluding Comments}

In summary, this analytical plan identifies two preparation blocks in Tables $3 \mathrm{a}$ and $3 \mathrm{~b}$ and several ICP-AES calibration blocks in Tables $4 \mathrm{a}$ and $4 \mathrm{~b}$ for use by the SRTC-ML. The sequencing of the activities associated with each of the steps in the analytical procedures has been randomized. The size of each of the blocks was selected so that it could be completed in a single work shift.

If a problem is discovered while measuring samples in a calibration block, the instrument should be calibrated and the block of samples re-measured in its entirety. If the measurements for one or more of the elements are determined using a different sample preparation method than outlined above, the changes should be noted with the other information reported by the SRTC-ML. This is also true for changes in the measurement order.

The analytical plan indicated in this memorandum should be modified by the personnel of SRTCML to include any calibration check standards and/or other standards that are part of their routine operating procedures. It is also recommended that the solutions resulting from each of the prepared samples be archived for some period, considering the "shelf-life" of the solutions, in case questions arise during data analysis. This would allow for the solutions to be rerun without additional preparations, thus minimizing cost.

\subsection{REFERENCE}

[1] Jantzen, C. M., J. B. Pickett, K. G. Brown, T. B. Edwards, and D. C. Beam, "Process/Product Models for the Defense Waste Processing Facility (DWPF): Part I. Predicting Glass Durability from Composition Using a Thermodynamic Hydration Energy Reaction Model (THERMO ${ }^{\mathrm{TM}}$ ) (U)," WSRC-TR-93-673, Rev. 1, Volume 2, Table B.1, pp. B.9, 1995. 


\section{APPENDIX C}

\section{PCT Analytical Plan}




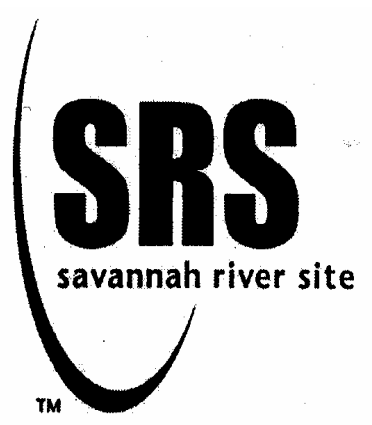

\section{WESTINGHOUSE SAVANNAH RIVER COMPANY INTEROFFICE MEMORANDUM}

SRT-SCS-2004-00019

April 30, 2004

To:

D. K. Peeler, 999-W

cc:

R. A. Baker, 773-42A

D. R. Best, 786-1A (wo)

P. A. Toole, 786-1A (wo)

S. L. Marra, 999-W (es)

R. C. Tuckfield, 773-42A

I. A. Reamer, 999-1W

R. J. Workman, 999-1W

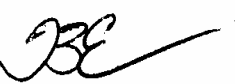

From: T. B. Edwards, 773-42A (5-5148)

Statistical Consulting Section

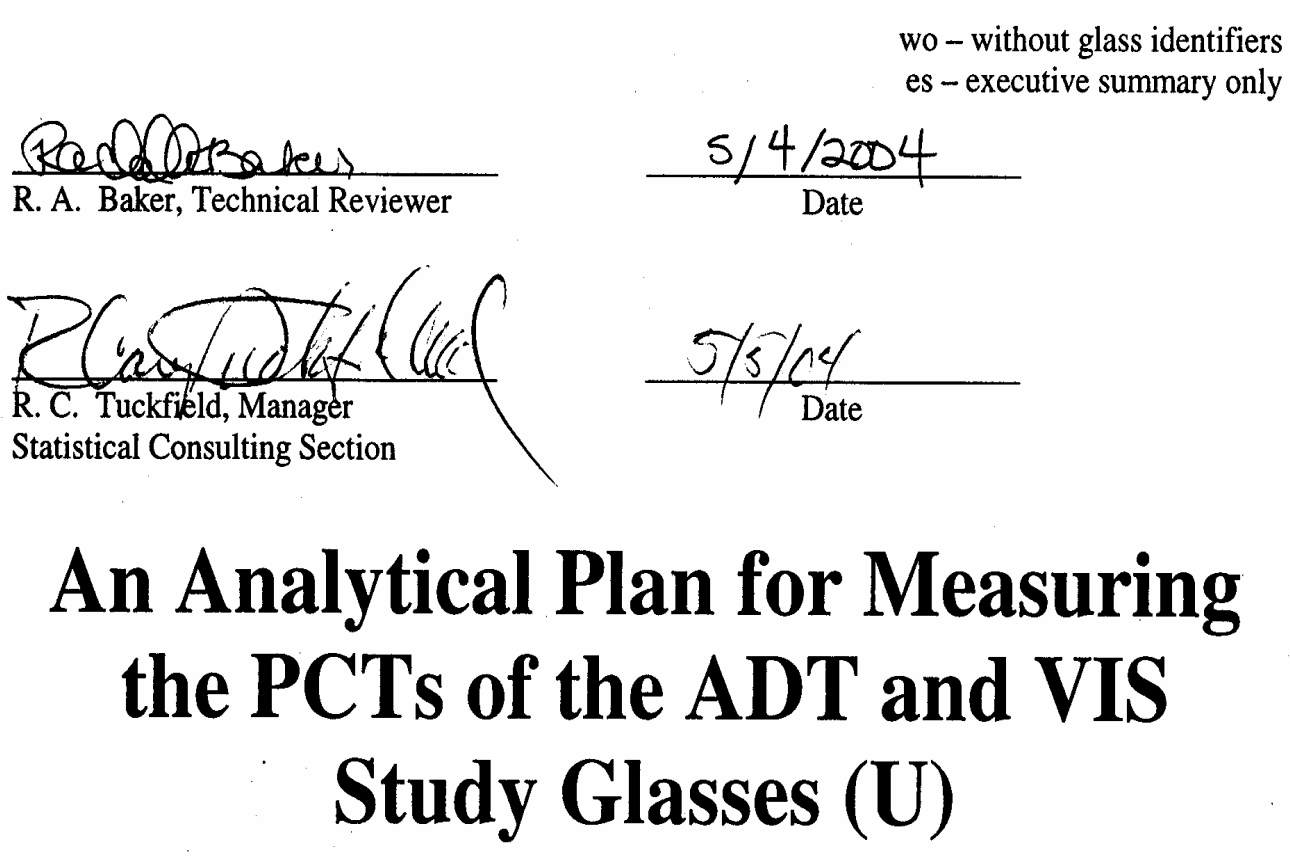




\subsection{EXECUTIVE SUMMARY}

This memorandum has been prepared to assist two glass studies that are being conducted by the Savannah River Technology Center (SRTC) in support of the accelerated mission at the Defense Waste Processing Facility (DWPF). One study is investigating the relationship between viscosity and waste loading for the Sludge Batch 3 (SB3)/Frit 418 glass system, while the second study is investigating alternative durability options for the DWPF. Glasses are being batched and fabricated for each of these studies: 6 glasses (designated by a "VIS" prefix for VIScosity) for the first study and 8 glasses (designated by an "ADT" prefix for Alternative Durability Task) for the second study. The durability of a glass is measured using the Product Consistency Test (PCT) as defined in ASTM C-1285-2002. For these studies, the durabilities of two different cooling treatments - quenched and centerline-canister-cooled ( $\mathrm{ccc}$ - - are to be measured for the glasses.

The Savannah River Technology Center-Mobile Laboratory (SRTC-ML) is to be used to measure elemental concentrations of the resulting leachate solutions from the PCTs. This memorandum provides an analytical plan for the SRTC-ML to follow in measuring the compositions of the leachate solutions resulting from the PCT procedures for these glasses.

\subsection{INTRODUCTION}

This memorandum has been prepared to assist two glass studies that are being conducted by the Savannah River Technology Center (SRTC) in support of the accelerated mission at the Defense Waste Processing Facility (DWPF). One study is investigating the relationship between viscosity and waste loading for the Sludge Batch 3 (SB3)/Frit 418 glass system, while the second study is investigating alternative durability options for the DWPF. Glasses are being batched and fabricated for each of these studies: 6 glasses (designated by a "VIS" prefix for VIScosity) for the first study and 8 glasses (designated by an "ADT" prefix for Alternative Durability Task) for the second study. The durability of a glass is measured using the Product Consistency Test (PCT) as defined in ASTM C-1285-2002 [1]. For these studies, the durabilities of two different cooling treatments - quenched and centerline-canister-cooled (ccc) - are to be measured for the glasses.

The Savannah River Technology Center-Mobile Laboratory (SRTC-ML) is to be used to measure elemental concentrations of the resulting leachate solutions from the PCTs. This memorandum provides an analytical plan for the SRTC-ML to follow in measuring the compositions of the leachate solutions resulting from the PCT procedures for these glasses.

\subsection{DISCUSSION}

Both heat treatments of the 14 study glasses are to be subjected to the PCT in triplicate. In addition to the 84 ( $=14$ glasses $\times 2$ heat treatments $\times 3$ PCTs each) PCTs required for the study glasses, triplicate PCTs are to be conducted on a sample of the Approved Reference Material (ARM) glass and a sample of the Environmental Assessment (EA) glass. Two reagent blank samples are also to be included in these tests. This results in 92 sample solutions being required to complete these PCTs.

The leachates from these tests will be diluted by adding $4 \mathrm{~mL}$ of $0.4 \mathrm{M} \mathrm{HNO}_{3}$ to $6 \mathrm{~mL}$ of the leachate (a 6:10 volume to volume, v:v, dilution) before being submitted to the SRTC-ML. The EA leachates will be further diluted $(1: 10 \mathrm{v}: \mathrm{v})$ with deionized water prior to submission to the SRTC-ML in order to prevent problems with the nebulizer. 
Table 1 presents identifying codes, pa01 through pa92, for the individual solutions required for the PCTs of the study glasses and of the standards (EA, ARM, and blanks). This provides a naming convention that is to be used by the SRTC-ML in analyzing the solutions and reporting the relevant concentration measurements. ${ }^{15}$

Table 1: Identifiers for the PCT Solutions

\begin{tabular}{|c|c|c|c|c|c|}
\hline $\begin{array}{l}\text { Original } \\
\text { Sample }\end{array}$ & $\begin{array}{c}\text { Solution } \\
\text { Identifier }\end{array}$ & $\begin{array}{l}\text { Original } \\
\text { Sample }\end{array}$ & $\begin{array}{c}\text { Solution } \\
\text { Identifier }\end{array}$ & $\begin{array}{l}\text { Original } \\
\text { Sample }\end{array}$ & $\begin{array}{c}\text { Solution } \\
\text { Identifier }\end{array}$ \\
\hline VIS-1 & pa11 & VIS-6 & pa56 & ADT-5 & pa67 \\
\hline VIS-1 & pa05 & VIS-6 & pa74 & ADT-5ccc & pa71 \\
\hline VIS-1 & pa45 & VIS-6ccc & pa54 & ADT-5ccc & pa58 \\
\hline VIS-1ccc & pa39 & VIS-6ccc & pa34 & ADT-5ccc & pa52 \\
\hline VIS- $1 \mathrm{ccc}$ & pa20 & VIS-6ccc & pa66 & ADT-6 & pa03 \\
\hline VIS-1cec & pa26 & ADT-1 & pa24 & ADT-6 & pa62 \\
\hline VIS-2 & pa79 & ADT-1 & pa06 & ADT-6 & pa16 \\
\hline VIS-2 & pa63 & ADT-1 & pa69 & ADT-6ccc & pa18 \\
\hline VIS-2 & pa23 & ADT-1ccc & pa44 & ADT-6ccc & pa28 \\
\hline VIS-2cec & pa29 & ADT-1ccc & pa49 & ADT-6ccc & pa90 \\
\hline VIS-2ccc & pa80 & ADT-1ccc & pa91 & ADT-7 & pa25 \\
\hline VIS-2cce & pa50 & ADT-2 & pa46 & ADT-7 & pa86 \\
\hline VIS-3 & pa12 & ADT-2 & pa87 & ADT-7 & pa84 \\
\hline VIS-3 & pa61 & ADT-2 & pa76 & ADT-7ccc & pa08 \\
\hline VIS-3 & pa60 & ADT-2ccc & pa07 & ADT-7ccc & pa85 \\
\hline VIS-3cce & pa33 & ADT-2ccc & pa83 & ADT-7ccc & pa19 \\
\hline VIS-3cce & pa59 & ADT-2ccc & pa81 & ADT-8 & pa15 \\
\hline VIS-3ccc & pa10 & ADT-3 & pa73 & ADT-8 & pa89 \\
\hline VIS-4 & pa31 & ADT-3 & pa57 & ADT-8 & pa22 \\
\hline VIS-4 & pa48 & ADT-3 & pa88 & ADT- $8 \mathrm{ccc}$ & pa55 \\
\hline VIS-4 & pa01 & ADT $-3 c c c$ & pa65 & ADT- $8 \mathrm{ccc}$ & pa70 \\
\hline VIS-4cec & pa04 & ADT $-3 c c c$ & pa41 & ADT-8ccc & pa51 \\
\hline VIS-4ccc & pa64 & ADT-3ccc & pa40 & ARM & pa72 \\
\hline VIS-4cce & pa75 & ADT-4 & pa21 & ARM & pa68 \\
\hline VIS-5 & pa02 & ADT-4 & pa47 & ARM & pa38 \\
\hline VIS-5 & pa82 & ADT-4 & pa17 & EA & pa92 \\
\hline VIS-5 & pa42 & ADT-4ccc & pa30 & EA & pa36 \\
\hline VIS-5ccc & pa77 & ADT-4ccc & pa32 & EA & pa43 \\
\hline VIS-5ccc & pa53 & ADT-4ccc & pa78 & blank & pa09 \\
\hline VIS-5 $\mathrm{ccc}$ & pa35 & ADT-5 & pa13 & blank & pa27 \\
\hline VIS-6 & pa37 & ADT-5 & pa14 & & \\
\hline
\end{tabular}

\subsection{Analytical Plan}

The analytical plan for the SRTC-ML is provided in this section. Each of the solution samples submitted to the SRTC-ML is to be analyzed only once for each of the following: aluminum, $(\mathrm{Al})$, boron $(\mathrm{B})$, iron $(\mathrm{Fe})$, lithium $(\mathrm{Li})$, sodium $(\mathrm{Na})$, silicon $(\mathrm{Si})$, and uranium $(\mathrm{U})$. The measurements are to be made in parts per million (ppm). The analytical procedure used by the SRTC-ML to determine the concentrations utilizes an Inductively Coupled Plasma - Atomic Emission Spectrometer (ICP-AES). The PCT solutions (as identified in Table 1) are grouped in six ICP-AES blocks for processing by the SRTC-ML in Table 2. Each block requires a different calibration of the ICP-AES.

15

Renaming these samples ensures that they will be processed as blind samples by the SRTC-ML. This table does not contain the solution identifiers for those on the distribution list with a "wo" following their names. 
Table 2: ICP-AES Calibration Blocks for Leachate Measurements

\begin{tabular}{|cccccc|}
\hline Block 1 & Block 2 & Block 3 & Block 4 & Block 5 & Block 6 \\
\hline std-b1-1 & std-b2-1 & std-b3-1 & std-b4-1 & std-b5-1 & std-b6-1 \\
pa39 & pa63 & pa38 & pa19 & pa52 & pa41 \\
pa64 & pa20 & pa26 & pa70 & pa32 & pa86 \\
pa80 & pa66 & pa75 & pa22 & pa73 & pa47 \\
pa05 & pa53 & pa74 & pa69 & pa28 & pa58 \\
pa60 & pa92 & pa34 & pa43 & pa65 & pa57 \\
pa33 & pa59 & pa79 & pa90 & pa36 & pa15 \\
std-b1-2 & std-b2-2 & std-b3-2 & pa62 & pa89 & pa03 \\
pa77 & pa01 & pa31 & pa40 & pa17 & pa72 \\
pa68 & pa12 & pa61 & std-b4-2 & std-b5-2 & std-b6-2 \\
pa27 & pa29 & pa50 & pa71 & pa44 & pa18 \\
pa48 & pa04 & pa45 & pa25 & pa08 & pa13 \\
pa56 & pa82 & pa10 & pa87 & pa16 & pa55 \\
pa54 & pa11 & pa42 & pa83 & pa24 & pa30 \\
pa02 & pa37 & pa35 & pa91 & pa14 & pa09 \\
pa23 & std-b2-3 & std-b3-3 & pa88 & pa84 & pa76 \\
std-b1-3 & & & pa67 & pa51 & pa85 \\
& & & pa78 & pa81 & pa06 \\
& & & pa21 & pa46 & pa49 \\
& & & std-b4-3 & std-b5-3 & pa07 \\
& & & & & std-b6-3 \\
\hline
\end{tabular}

A multi-element solution standard (denoted by "std-bi-j" where $i=1$ to 6 represents the block number and $\mathrm{j}=1,2$, and 3 represents the position in the block) was added at the beginning, middle, and end of each of the six blocks. This standard may be useful in checking for bias in the concentration measurements arising from the ICP calibrations.

\subsection{SUMMARY}

In summary, this analytical plan provides identifiers for the PCT solutions in Table 1 and six ICPAES calibration blocks in Table 2 for the SRTC-ML to use in conducting the aluminum, (Al), boron $(\mathrm{B})$, iron $(\mathrm{Fe})$, lithium $(\mathrm{Li})$, sodium $(\mathrm{Na})$, silicon $(\mathrm{Si})$, and uranium $(\mathrm{U})$ concentration measurements for this PCT study. The sequencing of the activities associated with each of the steps in the analytical procedure has been randomized. The size of the blocks was selected so that the block could be completed in a single work shift. If for some reason the measurements are not conducted in the sequence presented in this memorandum, the actual order should be recorded along with any explanative comments.

The analytical plan indicated in the preceding tables should be modified by the personnel of the SRTC-ML to include any calibration check standards and/or other standards that are part of their standard operating procedures.

\subsection{REFERENCE}

[1] ASTM C-1285-2002, "Standard Test Methods for Determining Chemical Durability of Nuclear Waste Glasses: The Product Consistency Test (PCT),” ASTM, 2002. 
WSRC-TR-2004-00429

Revision 0

This page intentionally left blank. 


\section{APPENDIX D}

Tables and Exhibits Supporting the Analysis of the Chemical Composition Measurements of the VIS Study Glasses 
Table D1. Targeted Oxide Concentrations (as wt\%'s) for the VIS Study Glasses

\begin{tabular}{|c|c|c|c|c|c|c|c|c|c|c|c|c|c|c|c|c|c|c|c|c|c|c|c|}
\hline Glass ID & 1203 & 3 & $\mathrm{aO}$ & $\mathrm{aO}$ & $\mathbf{0 3}$ & TC & $\mathrm{uO}$ & $\overline{\mathbf{O 3}}$ & 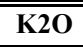 & 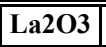 & 20 & 50 & 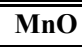 & 20 & $\Gamma$ & 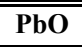 & 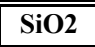 & 22 & $\overline{02}$ & 8 & 10 & $\overline{2}$ & m \\
\hline VIS-1 & 4.593 & 5.600 & 44 & 3 & 0.072 & 72 & 27 & 9.809 & 963 & 0035 & 600 & 0 & 06 & 207 & $\overline{52}$ & 043 & 29 & 010 & 010 & 3.083 & .046 & 30 & 99 \\
\hline VIS-2 & 5.052 & 5.360 & 0.049 & .960 & 0.079 & 0.079 & 0.030 & 0.791 & 0.069 & 0.038 & 5.360 & 1.177 & 2.206 & 12.628 & 0.582 & 0.047 & 51.942 & 0.012 & 0.011 & 3.391 & 0.050 & 0.088 & 00.000 \\
\hline VIS-3 & 359 & 200 & 052 & .018 & 084 & 083 & .031 & 45 & 0.073 & 041 & 5.200 & .248 & .340 & 2.908 & 0.617 & .050 & 0.484 & 0.012 & 0.012 & 3.597 & .053 & 0.093 & 00.000 \\
\hline VIS-4 & 5.665 & 5.040 & 0.055 & 1.076 & 0.088 & 0.088 & 0.033 & 12.099 & 0.077 & 0.043 & 5.040 & 1.319 & 2.474 & 13.189 & 0.653 & 0.053 & 49.026 & 0.013 & 0.013 & 3.802 & 0.056 & 0.099 & 100.000 \\
\hline VIS-5 & 6.124 & 4.800 & 059 & 1.164 & 0.096 & 0.095 & 0.036 & 13.080 & 0.084 & 0.047 & 4.800 & 1.426 & 2.674 & 13.607 & 0.706 & 0.057 & 46.839 & 0.014 & 0.014 & 4.110 & 0.061 & 0.107 & 99.997 \\
\hline VIS-6 & 6.890 & 4.400 & 0.059 & 1.309 & 0.107 & 0.107 & 0.040 & 14.715 & 0.094 & 0.052 & 4.400 & 1.605 & 3.008 & 14.311 & 0.794 & 0.064 & 43.200 & 0.016 & 0.015 & 4.624 & 0.069 & 0.120 & 99.999 \\
\hline
\end{tabular}


Table D2. Measured Elemental Concentrations (wt\%) for Samples Prepared Using Lithium Metaborate

\begin{tabular}{|c|c|c|c|c|c|c|c|c|c|c|c|c|c|c|c|c|c|c|c|c|c|c|c|c|}
\hline " Glass & "SRNL-ML & & Sub- & Analytical & & & & & & & & & & & & & & & & & & & & \\
\hline ID & ID & Block & Block & Sequence & $\overline{\mathbf{A l}}$ & Ba & $\mathbf{C a}$ & $\mathrm{Ce}$ & $\mathrm{Cr}$ & $\mathrm{Cu}$ & $\mathrm{Fe}$ & $\mathbf{K}$ & $\mathbf{L a}$ & Mg & Mn & $\mathrm{Na}$ & $\mathrm{Ni}$ & $\mathbf{P b}$ & $\mathrm{Si}$ & Th & $\mathrm{Ti}$ & $\overline{\mathbf{U}}$ & $\mathbf{Z n}$ & $\mathbf{Z r}$ \\
\hline Batch 1 & CHLM111 & 1 & 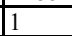 & $I^{1}$ & 2.61 & 0.129 & 0.857 & $<0.010$ & 0.076 & 0.299 & 8.91 & 2.54 & $<0.010$ & 0.818 & 1.34 & \begin{tabular}{|l|}
6.84 \\
\end{tabular} & 0.548 & $<0.020$ & 24.1 & $<0.100$ & 0.390 & $<0.100$ & $<<0.010$ & 0.076 \\
\hline Ustd & STDLM111 & & 1 & 2 & 2.08 & $\begin{array}{l}<0.010 \\
\end{array}$ & 0.867 & $<0.010$ & 0.159 & 0.012 & 9.09 & 2.42 & $<0.010$ & 0.675 & 2.16 & 8.78 & 0.754 & $<0.020$ & 21.1 & $<0.100$ & 0.541 & 1.98 & $<0.010$ & $<0.010$ \\
\hline VIS-6 & A14LM11 & 1 & 1 & 3 & 3.78 & 0.051 & 0.917 & 0.065 & 0.051 & 0.044 & 9.02 & 0.103 & 0.037 & 0.861 & 2.34 & 10.7 & 0.503 & 0.063 & \begin{tabular}{|l|l|}
19.8 \\
\end{tabular} & $<0.100$ & 0.015 & 3.66 & 0.090 & 0.068 \\
\hline ADT-7 & A2LM21 & & t & 4 & 2.94 & 0.045 & 0.694 & \begin{tabular}{|l|}
0.049 \\
\end{tabular} & 0.057 & \begin{tabular}{|l|}
0.037 \\
\end{tabular} & 7.64 & 0.073 & 0.031 & 0.711 & 1.83 & 12.7 & 0.433 & 0.048 & 22.2 & $<0.100$ & 0.013 & 2.91 & 0.041 & \begin{tabular}{|l|}
0.062 \\
\end{tabular} \\
\hline VIS-2 & $05 \mathrm{LM}$ & & 1 & 5 & 2.79 & 0.041 & 0.670 & 0.047 & 0.049 & 0.034 & 6.84 & 0.072 & 0.029 & 0.645 & 1.72 & 9.41 & 0.388 & 0.042 & 23.7 & $<0.100$ & 0.012 & 2.77 & 0.041 & 0.056 \\
\hline ADT-6 & 407LM11 & & 1 & 6 & 3.33 & 0.050 & 0.809 & 0.060 & 0.063 & 0.039 & 8.82 & 0.084 & 0.035 & 0.799 & 2.07 & 11.8 & 0.492 & 0.054 & 20.6 & $<0.100$ & 0.013 & 3.36 & 0.048 & $\begin{array}{l}0.068 \\
\end{array}$ \\
\hline VIS-3 & 409LM21 & 11 & 1 & 7 & 3.02 & 0.048 & 0.734 & 0.054 & 0.061 & $\begin{array}{l}0.037 \\
\end{array}$ & 7.25 & \begin{tabular}{|l|}
0.074 \\
\end{tabular} & 0.031 & 0.709 & 1.86 & 9.83 & 0.436 & 0.052 & 23.7 & $<0.100$ & 0.012 & 2.84 & 0.041 & 0.062 \\
\hline VIS-1 & $111 \mathrm{LM}$ & & 1 & 8 & 2.54 & 0.040 & 0.601 & 0.050 & 0.048 & 0.031 & 6.42 & \begin{tabular}{|l|}
0.061 \\
\end{tabular} & 0.027 & 0.620 & 1.57 & 9.05 & 0.380 & 0.043 & 25.2 & $<0.100$ & 0.011 & 2.46 & 0.048 & 0.054 \\
\hline VIS-2 & 405LN & & 1 & 9 & 2.80 & 0.042 & 0.673 & 0.048 & 0.050 & 0.035 & 6.92 & 0.070 & 0.030 & 0.663 & 1.74 & 9.42 & 0.400 & 0.043 & 24.1 & $<0.100$ & 0.012 & 2.77 & 0.041 & 0.057 \\
\hline Batch 1 & $\mathrm{CH}$ & 1 & 1 & 10 & 2.58 & 0.129 & 0.857 & $<0.010$ & 0.077 & 0.302 & 8.71 & 2.56 & $<0.010$ & 0.825 & 1.30 & \begin{tabular}{|l|}
6.77 \\
\end{tabular} & 0.551 & $<0.020$ & 24.0 & $<0.100$ & 0.389 & $<0.100$ & $<0.010$ & 0.077 \\
\hline Ustd & STDLM112 & 1 & 1 & 11 & 2.08 & $\begin{array}{l}<0.010 \\
\end{array}$ & 0.878 & $<0.010$ & 0.161 & 0.012 & 8.99 & 2.44 & $<0.010$ & 0.680 & 2.15 & 8.70 & 0.759 & $<0.020$ & 21.3 & $<0.100$ & 0.546 & 1.98 & $<0.010$ & $<0.010$ \\
\hline ADT-6 & A07LM21 & 1 & 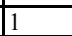 & 12 & 3.33 & 0.050 & 0.808 & 0.060 & 0.063 & 0.039 & 8.67 & 0.085 & 0.035 & 0.799 & 2.04 & 11.6 & 0.477 & 0.054 & 20.4 & $<0.100$ & 0.013 & 3.31 & 0.047 & 0.068 \\
\hline VIS-1 & & & 1 & 13 & 2.57 & 0.041 & 0.620 & 0.052 & 0.047 & 0.033 & 6.55 & 0.061 & 0.028 & $\begin{array}{l}0.637 \\
\end{array}$ & 1.60 & 9.09 & 0.392 & 0.043 & 25.3 & $<0.100$ & 0.011 & 2.50 & 0.037 & 0.056 \\
\hline VIS-5 & $\overline{401}$ & $I^{1}$ & ]$^{1}$ & 14 & 3.43 & 0.051 & 0.803 & 0.052 & 0.073 & 0.042 & 8.42 & 0.089 & 0.036 & 0.789 & 2.15 & 10.4 & 0.478 & 0.053 & 21.8 & $<0.100$ & 0.013 & 3.34 & 0.048 & 0.067 \\
\hline VIS-3 & $\mathrm{V}$ & 1 & t & 15 & 3.04 & 0.049 & 0.736 & 0.054 & 0.062 & 0.038 & 7.36 & 0.074 & 0.032 & 0.719 & 1.87 & 9.77 & 0.442 & 0.049 & 24.0 & $<0.100$ & 0.013 & 2.86 & 0.039 & 0.063 \\
\hline VIS-5 & $\mathrm{AO}$ & + & $\mid 1$ & 16 & 3.51 & 0.051 & 0.811 & 0.051 & 0.077 & 0.044 & 8.51 & $\begin{array}{l}0.094 \\
\end{array}$ & 0.036 & 0.793 & 2.18 & 10.6 & 0.476 & 0.053 & 22.3 & $<0.100$ & 0.013 & 3.40 & 0.074 & 0.068 \\
\hline ADT-7 & 10 & $I^{1}$ & trat & 17 & 2.89 & 0.043 & 0.671 & $\begin{array}{l}0.046 \\
\end{array}$ & 0.054 & 0.041 & 7.28 & $\begin{array}{ll}0.078 \\
\end{array}$ & 0.030 & 0.671 & 1.76 & 12.6 & 0.402 & 0.044 & 21.7 & $<0.100$ & 0.012 & 2.85 & 0.040 & 0.058 \\
\hline $\begin{array}{l}\text { VIS-6 } \\
\end{array}$ & & + & 1 & 18 & 3.84 & 0.052 & 0.914 & $\begin{array}{l}0.068 \\
\end{array}$ & 0.049 & \begin{tabular}{|l|}
0.044 \\
\end{tabular} & 9.04 & \begin{tabular}{|l|}
0.095 \\
\end{tabular} & 0.038 & 0.878 & 2.34 & $\begin{array}{l}10.8 \\
\end{array}$ & 0.516 & 0.057 & 20.8 & $<0.100$ & \begin{tabular}{|l|}
0.014 \\
\end{tabular} & 3.71 & 0.056 & 0.070 \\
\hline Ustd & 13 & 1 & 1 & 19 & 2.09 & \begin{tabular}{|c|}
$<0.010$ \\
\end{tabular} & $\begin{array}{l}0.879 \\
\end{array}$ & $<0.010$ & 0.162 & \begin{tabular}{|l|}
0.012 \\
\end{tabular} & 8.94 & 2.47 & $<0.010$ & \begin{tabular}{|l|}
0.680 \\
\end{tabular} & 2.13 & 8.82 & 0.758 & $\begin{array}{l}<0.020 \\
\end{array}$ & 21.5 & $\mid<0.100$ & 0.545 & 2.00 & $\mid<0.010$ & \begin{tabular}{|c|}
$<0.010$ \\
\end{tabular} \\
\hline \begin{tabular}{|l} 
Batch 1 \\
\end{tabular} & $\overline{\mathrm{CH}}$ & 1 & 1 & 20 & 2.64 & 0.130 & 0.858 & $<0.010$ & 0.078 & 0.305 & 8.70 & 2.57 & $<0.010$ & $\begin{array}{l}0.818 \\
\end{array}$ & 1.31 & \begin{tabular}{|l|l|}
6.89 \\
\end{tabular} & 0.553 & $<0.020$ & 24.3 & $<0.100$ & \begin{tabular}{|l|}
0.392 \\
\end{tabular} & $<0.100$ & $<0.010$ & 0.076 \\
\hline Batch 1 & B & $t^{2}$ & 2 & $t=0$ & 2.58 & 0.127 & \begin{tabular}{|l|l|}
0.867 \\
\end{tabular} & $<0.010$ & \begin{tabular}{|l|l|}
0.075 \\
\end{tabular} & \begin{tabular}{|l|}
0.303 \\
\end{tabular} & \begin{tabular}{|l|}
8.84 \\
\end{tabular} & \begin{tabular}{|l|}
2.59 \\
\end{tabular} & $<0.010$ & \begin{tabular}{|l|l|}
0.811 \\
\end{tabular} & \begin{tabular}{|l|l|}
1.34 \\
\end{tabular} & \begin{tabular}{|l|l|}
6.78 \\
\end{tabular} & 0.551 & $<0.020$ & \begin{tabular}{|l|}
24.0 \\
\end{tabular} & $<0.100$ & \begin{tabular}{|l|}
0.389 \\
\end{tabular} & $<0.100$ & $<<0.010$ & 0.076 \\
\hline Icts & & 1 & 2 & 2 & 2.08 & \begin{tabular}{|c|c|}
$<0.010$ \\
\end{tabular} & 0.866 & $<0.010$ & 0.160 & \begin{tabular}{|l|}
0.009 \\
\end{tabular} & 9.05 & 2.45 & $<0.010$ & $\begin{array}{l}0.676 \\
\end{array}$ & 2.17 & 8.80 & 0.761 & $<0.020$ & 20.8 & $<0.100$ & \begin{tabular}{|l|}
0.547 \\
\end{tabular} & 1.96 & $<0.010$ & $<0.010$ \\
\hline \begin{tabular}{|l|} 
ADT-7 \\
\end{tabular} & $\mathrm{A} 0$ & $\mid$\begin{tabular}{|l}
$\mid 1$ \\
\end{tabular} & $\frac{2}{2}$ & 3 & 2.92 & 0.043 & 0.703 & \begin{tabular}{|l|l|}
0.050 \\
\end{tabular} & $\begin{array}{l}0.055 \\
\end{array}$ & \begin{tabular}{|l|}
0.035 \\
\end{tabular} & $\begin{array}{l}7.68 \\
\end{array}$ & \begin{tabular}{|l|}
0.071 \\
\end{tabular} & \begin{tabular}{|l}
0.031 \\
\end{tabular} & \begin{tabular}{|l|l|}
0.711 \\
\end{tabular} & \begin{tabular}{|l|}
1.86 \\
\end{tabular} & \begin{tabular}{|l|l}
12.7 \\
\end{tabular} & 0.438 & 0.048 & \begin{tabular}{|l|}
22.4 \\
\end{tabular} & $<0.100$ & \begin{tabular}{|l|}
0.012 \\
\end{tabular} & \begin{tabular}{|l|}
2.90 \\
\end{tabular} & 0.040 & 0.061 \\
\hline VIS-5 & & & 2 & 4 & 3.48 & \begin{tabular}{|l|}
0.049 \\
\end{tabular} & 0.811 & \begin{tabular}{|l|}
0.051 \\
\end{tabular} & \begin{tabular}{|l|}
0.077 \\
\end{tabular} & \begin{tabular}{|l|}
0.042 \\
\end{tabular} & 8.62 & \begin{tabular}{|l|}
0.092 \\
\end{tabular} & $\begin{array}{l}0.036 \\
\end{array}$ & \begin{tabular}{|l|}
0.786 \\
\end{tabular} & 2.22 & 10.4 & 0.477 & \begin{tabular}{|l|}
0.052 \\
\end{tabular} & 22.1 & $<0.100$ & 0.012 & 3.34 & 0.072 & \begin{tabular}{|l|}
0.068 \\
\end{tabular} \\
\hline \begin{tabular}{|l} 
VIS-3 \\
\end{tabular} & & 1 & 2 & 5 & 3.00 & \begin{tabular}{|l|}
0.047 \\
\end{tabular} & 0.740 & \begin{tabular}{|l|}
0.054 \\
\end{tabular} & $\begin{array}{l}0.060 \\
\end{array}$ & \begin{tabular}{|l|}
0.036 \\
\end{tabular} & 7.45 & \begin{tabular}{|l|}
0.072 \\
\end{tabular} & \begin{tabular}{|l|l}
0.031 \\
\end{tabular} & \begin{tabular}{|l|l}
0.714 \\
\end{tabular} & 1.92 & 9.62 & 0.442 & 0.048 & 23.9 & $<0.100$ & 0.012 & 2.83 & 0.037 & 0.063 \\
\hline \begin{tabular}{|l|} 
ADT-6 \\
\end{tabular} & & 1 & 2 & 6 & 3.32 & \begin{tabular}{|l|}
0.047 \\
\end{tabular} & 0.803 & \begin{tabular}{|l|}
0.059 \\
\end{tabular} & \begin{tabular}{|l|}
0.061 \\
\end{tabular} & \begin{tabular}{|l|}
0.036 \\
\end{tabular} & 8.94 & \begin{tabular}{|l|}
0.081 \\
\end{tabular} & \begin{tabular}{|l|} 
\\
\end{tabular} & \begin{tabular}{|l|}
0.789 \\
\end{tabular} & 2.11 & 11.5 & 0.476 & \begin{tabular}{|l|}
0.052 \\
\end{tabular} & 20.5 & $<0.100$ & 0.012 & 3.29 & 0.046 & \begin{tabular}{|l|}
0.067 \\
\end{tabular} \\
\hline \begin{tabular}{|l} 
VIS-6 \\
\end{tabular} & & 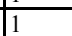 & 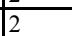 & 7 & 3.76 & 0.049 & 0.912 & \begin{tabular}{|l|}
0.067 \\
\end{tabular} & 0.047 & $\begin{array}{l}0.042 \\
\end{array}$ & 9.54 & \begin{tabular}{|l|}
0.092 \\
\end{tabular} & 0.037 & 0.870 & \begin{tabular}{|l|}
2.42 \\
\end{tabular} & 10.4 & 0.517 & 0.056 & 20.5 & $<0.100$ & \begin{tabular}{|l|}
0.013 \\
\end{tabular} & 3.64 & 0.054 & 0.071 \\
\hline \begin{tabular}{|l|} 
ADT-7 \\
\end{tabular} & & 1 & 2 & 8 & 2.85 & \begin{tabular}{|l|}
0.041 \\
\end{tabular} & \begin{tabular}{|l|}
0.677 \\
\end{tabular} & \begin{tabular}{|l|}
0.046 \\
\end{tabular} & $\begin{array}{l}0.052 \\
\end{array}$ & \begin{tabular}{|l|}
0.038 \\
\end{tabular} & 7.33 & \begin{tabular}{|l|}
0.075 \\
\end{tabular} & $\begin{array}{l}0.029 \\
\end{array}$ & \begin{tabular}{|l|}
0.663 \\
\end{tabular} & 1.79 & 12.3 & 0.401 & \begin{tabular}{|l|}
0.044 \\
\end{tabular} & \begin{tabular}{|l|}
21.6 \\
\end{tabular} & $<0.100$ & 0.011 & 2.81 & 0.038 & 0.059 \\
\hline VIS-1 & & & 2 & 9 & 2.52 & 0.038 & 0.616 & \begin{tabular}{|l|}
0.051 \\
\end{tabular} & $\begin{array}{l}0.047 \\
\end{array}$ & \begin{tabular}{|l|}
0.029 \\
\end{tabular} & 6.56 & $\begin{array}{l}0.060 \\
\end{array}$ & $\begin{array}{l}0.027 \\
\end{array}$ & \begin{tabular}{|l|}
0.624 \\
\end{tabular} & 1.62 & 8.94 & 0.383 & 0.044 & 24.8 & $<0.100$ & 0.010 & 2.45 & 0.047 & 0.055 \\
\hline Batch 1 & & 1 & 2 & 10 & 2.56 & 0.128 & 0.864 & $<0.010$ & 0.076 & 0.303 & 8.77 & 2.60 & $<0.010$ & 0.820 & 1.33 & \begin{tabular}{|l|}
6.72 \\
\end{tabular} & 0.552 & $<<0.020$ & 23.7 & $<<0.100$ & 0.395 & $<0.100$ & $<<0.010$ & \begin{tabular}{|l|}
0.077 \\
\end{tabular} \\
\hline Ustd & & $I_{1}$ & 2 & 11 & 2.07 & \begin{tabular}{|c|c|}
$<0.010$ \\
\end{tabular} & 0.872 & $<0.010$ & 0.160 & \begin{tabular}{|l|}
0.009 \\
\end{tabular} & 9.11 & 2.46 & $<0.010$ & \begin{tabular}{|l|}
0.673 \\
\end{tabular} & 2.20 & 8.66 & 0.759 & $<0.020$ & \begin{tabular}{|l|}
20.9 \\
\end{tabular} & $<0.100$ & \begin{tabular}{|l|}
0.550 \\
\end{tabular} & 1.97 & $<0.010$ & $<0.010$ \\
\hline \begin{tabular}{|l} 
VIS-6 \\
\end{tabular} & $\mathrm{A} 1$ & +1 & $t$ & 12 & 3.76 & 0.048 & 0.920 & \begin{tabular}{|l|}
0.066 \\
\end{tabular} & 0.050 & \begin{tabular}{|l|}
0.042 \\
\end{tabular} & 9.07 & \begin{tabular}{|l|l|}
0.100 \\
\end{tabular} & \begin{tabular}{|l|l|}
0.037 \\
\end{tabular} & \begin{tabular}{|l|l|}
0.853 \\
\end{tabular} & \begin{tabular}{|l|}
2.38 \\
\end{tabular} & \begin{tabular}{|l|l|}
10.6 \\
\end{tabular} & 0.499 & \begin{tabular}{|l|}
0.062 \\
\end{tabular} & \begin{tabular}{|l|}
19.5 \\
\end{tabular} & $<0.100$ & \begin{tabular}{|l|}
0.013 \\
\end{tabular} & 3.63 & 0.089 & 0.070 \\
\hline VIS-2 & & & 2 & 13 & 2.78 & 0.039 & \begin{tabular}{|l|}
0.677 \\
\end{tabular} & \begin{tabular}{|l|}
0.048 \\
\end{tabular} & $\begin{array}{l}0.048 \\
\end{array}$ & \begin{tabular}{|l|}
0.032 \\
\end{tabular} & 6.90 & \begin{tabular}{|l|}
0.071 \\
\end{tabular} & \begin{tabular}{|l|}
0.029 \\
\end{tabular} & \begin{tabular}{|l|}
0.641 \\
\end{tabular} & \begin{tabular}{|l|}
1.75 \\
\end{tabular} & \begin{tabular}{|l|}
9.27 \\
\end{tabular} & 0.388 & \begin{tabular}{|l|}
0.041 \\
\end{tabular} & 23.6 & $<0.100$ & 0.011 & \begin{tabular}{|l|}
2.76 \\
\end{tabular} & 0.040 & 0.058 \\
\hline VIS-3 & & 1 & $1^{2}$ & 14 & 2.98 & 0.046 & 0.751 & \begin{tabular}{|l|}
0.055 \\
\end{tabular} & $\begin{array}{l}0.060 \\
\end{array}$ & \begin{tabular}{|l|}
0.035 \\
\end{tabular} & 7.23 & \begin{tabular}{|l|}
0.072 \\
\end{tabular} & 0.031 & \begin{tabular}{|l|l}
0.710 \\
\end{tabular} & 1.86 & 9.64 & 0.436 & 0.051 & \begin{tabular}{|l|}
23.3 \\
\end{tabular} & $<0.100$ & \begin{tabular}{|l|}
0.012 \\
\end{tabular} & 2.80 & 0.039 & 0.063 \\
\hline VIS-5 & & & 2 & 15 & 3.42 & 0.048 & 0.805 & \begin{tabular}{|l|}
0.052 \\
\end{tabular} & \begin{tabular}{|l|}
0.072 \\
\end{tabular} & \begin{tabular}{|l|}
0.040 \\
\end{tabular} & 8.46 & \begin{tabular}{|l|}
0.088 \\
\end{tabular} & $\begin{array}{l}0.036 \\
\end{array}$ & \begin{tabular}{|l|}
0.783 \\
\end{tabular} & 2.19 & 10.4 & 0.476 & \begin{tabular}{|l|}
0.051 \\
\end{tabular} & 21.4 & $<0.100$ & 0.012 & 3.33 & 0.046 & 0.068 \\
\hline VIS & & & 2 & 16 & 2.82 & 0.041 & \begin{tabular}{|l|l}
0.678 \\
\end{tabular} & \begin{tabular}{|l|}
0.049 \\
\end{tabular} & \begin{tabular}{|l|}
0.049 \\
\end{tabular} & \begin{tabular}{|l|}
0.033 \\
\end{tabular} & 6.89 & \begin{tabular}{|l|}
0.069 \\
\end{tabular} & $\begin{array}{l}0.030 \\
\end{array}$ & \begin{tabular}{|l|}
0.665 \\
\end{tabular} & 1.76 & 9.56 & 0.400 & $\begin{array}{l}0.042 \\
\end{array}$ & 23.7 & $<0.100$ & \begin{tabular}{|l|}
0.011 \\
\end{tabular} & \begin{tabular}{|l|}
2.78 \\
\end{tabular} & 0.040 & 0.058 \\
\hline \begin{tabular}{|l|l} 
ADT-6 \\
\end{tabular} & i & 11 & 2 & 17 & 3.32 & 0.048 & 0.817 & 0.060 & 0.062 & \begin{tabular}{|l|}
0.037 \\
\end{tabular} & 8.76 & \begin{tabular}{|l|}
0.083 \\
\end{tabular} & 0.035 & \begin{tabular}{|l|}
0.801 \\
\end{tabular} & 2.08 & 11.8 & 0.492 & \begin{tabular}{|l|}
0.052 \\
\end{tabular} & 20.3 & $<0.100$ & 0.012 & 3.34 & 0.046 & 0.070 \\
\hline \begin{tabular}{|l} 
VIS-1 \\
\end{tabular} & & & 年 & 18 & 2.56 & 0.039 & 0.613 & $\begin{array}{l}0.052 \\
\end{array}$ & $\begin{array}{l}0.045 \\
\end{array}$ & $\begin{array}{l}0.030 \\
\end{array}$ & 6.50 & \begin{tabular}{|l|}
0.057 \\
\end{tabular} & 0.027 & $\begin{array}{l}0.634 \\
\end{array}$ & \begin{tabular}{|l|l}
1.61 \\
\end{tabular} & 9.07 & 0.392 & 0.043 & \begin{tabular}{|l|}
24.9 \\
\end{tabular} & $<0.100$ & \begin{tabular}{|l|}
0.010 \\
\end{tabular} & 2.48 & 0.035 & 0.056 \\
\hline Ustd & & 1 & $t 2$ & 19 & 2.07 & \begin{tabular}{|l|l|}
$<0.010$ \\
\end{tabular} & \begin{tabular}{|l|l|}
0.878 \\
\end{tabular} & $<0.010$ & \begin{tabular}{|l|l|}
0.160 \\
\end{tabular} & \begin{tabular}{|l|}
0.009 \\
\end{tabular} & \begin{tabular}{|l}
9.08 \\
\end{tabular} & \begin{tabular}{|l|}
2.47 \\
\end{tabular} & $<0.010$ & \begin{tabular}{|l|}
0.674 \\
\end{tabular} & \begin{tabular}{|l|l|} 
\\
\end{tabular} & 8.66 & 0.755 & $<0.020$ & 21.0 & $<0.100$ & \begin{tabular}{|l|l}
0.552 \\
\end{tabular} & \begin{tabular}{|l|}
1.96 \\
\end{tabular} & $<0.010$ & \begin{tabular}{|l|l|}
$<0.010$ \\
\end{tabular} \\
\hline \begin{tabular}{|l} 
Batch 1 \\
\end{tabular} & & 11 & 2 & 20 & 2.59 & 0.127 & 0.869 & $<0.010$ & $\begin{array}{l}0.076 \\
\end{array}$ & 0.305 & 8.82 & 2.61 & $<0.010$ & $\begin{array}{l}0.819 \\
\end{array}$ & 1.34 & 6.72 & 0.550 & $<0.020$ & 23.5 & $<0.100$ & \begin{tabular}{|l|}
0.394 \\
\end{tabular} & $<0.100$ & $<0.010$ & 0.076 \\
\hline Batch 1 & & & 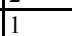 & te & 2.59 & 0.128 & 0.852 & $<0.010$ & 0.076 & \begin{tabular}{|l|}
0.300 \\
\end{tabular} & \begin{tabular}{|l|}
8.85 \\
\end{tabular} & 2.57 & $<0.010$ & \begin{tabular}{|l|l|}
0.811 \\
\end{tabular} & \begin{tabular}{|l|}
1.34 \\
\end{tabular} & $\begin{array}{l}6.78 \\
\end{array}$ & 0.549 & $<0.020$ & \begin{tabular}{|l|}
24.0 \\
\end{tabular} & $<0.100$ & \begin{tabular}{|l|}
0.389 \\
\end{tabular} & $<0.100$ & $<<0.010$ & \begin{tabular}{|l|l|}
0.077 \\
\end{tabular} \\
\hline Ustd & & {$[2$} & 1 & 2 & 2.11 & \begin{tabular}{|c|c|}
$<0.010$ \\
\end{tabular} & 0.862 & $<0.010$ & 0.160 & $\begin{array}{l}0.010 \\
\end{array}$ & 9.01 & 2.45 & $<0.010$ & \begin{tabular}{|l|l}
0.677 \\
\end{tabular} & 2.18 & 8.89 & 0.759 & $<0.020$ & 21.2 & $<0.100$ & $\begin{array}{l}0.545 \\
\end{array}$ & 1.99 & $<0.010$ & $\begin{array}{l}<0.010 \\
\end{array}$ \\
\hline \begin{tabular}{|l|} 
VIS-4 \\
\end{tabular} & A12LM11 & 2 & 1 & 3 & 3.21 & 0.046 & \begin{tabular}{|l|l|}
0.747 \\
\end{tabular} & \begin{tabular}{|l|}
0.056 \\
\end{tabular} & 0.069 & \begin{tabular}{|l|}
0.037 \\
\end{tabular} & $\begin{array}{l}7.84 \\
\end{array}$ & \begin{tabular}{|l|}
0.075 \\
\end{tabular} & 0.031 & \begin{tabular}{|l|l|}
0.733 \\
\end{tabular} & \begin{tabular}{|l|}
2.00 \\
\end{tabular} & 9.91 & 0.443 & \begin{tabular}{|l|}
0.049 \\
\end{tabular} & \begin{tabular}{|l|}
22.4 \\
\end{tabular} & $<0.100$ & \begin{tabular}{|l|}
0.013 \\
\end{tabular} & 3.10 & 0.048 & \begin{tabular}{|l}
0.061 \\
\end{tabular} \\
\hline \begin{tabular}{|l|} 
ADT-2 \\
\end{tabular} & VA13LM11 & 2 & 1 & 4 & 3.37 & 0.051 & 0.842 & \begin{tabular}{|l|}
0.047 \\
\end{tabular} & 0.050 & \begin{tabular}{|l|}
0.037 \\
\end{tabular} & 8.41 & 0.080 & 0.034 & 1.363 & 2.10 & 9.33 & 0.489 & 0.055 & 22.4 & $<0.100$ & 0.012 & 3.45 & 0.073 & 0.070 \\
\hline
\end{tabular}


Table D2. Measured Elemental Concentrations (wt\%) for Samples Prepared Using Lithium Metaborate

\begin{tabular}{|c|c|c|c|c|c|c|c|c|c|c|c|c|c|c|c|c|c|c|c|c|c|c|c|c|}
\hline Glass & "SRNL-ML & & \begin{tabular}{|l|} 
Sub- \\
\end{tabular} & $\overline{\text { Analytical }}$ & & & & & & & & & & & & & & & & & & & & \\
\hline ID & ID & Block & \begin{tabular}{|l|} 
Block \\
\end{tabular} & Sequence & $\mathbf{A l}$ & $\mathbf{B a}$ & $\mathbf{C a}$ & $\mathrm{Ce}$ & $\mathrm{Cr}$ & $\mathrm{Cu}$ & $\mathbf{F e}$ & $\mathbf{K}$ & $\mathbf{L a}$ & Mg & Mn & $\mathrm{Na}$ & $\mathrm{Ni}$ & $\mathbf{P b}$ & $\mathbf{S i}$ & Th & Ti & $\mathbf{U}$ & $\mathbf{Z n}$ & $\mathbf{Z r}$ \\
\hline ADT-1 & A03LM11 & 2 & 1 & 5 & 2.96 & 0.044 & 0.703 & 0.046 & 0.045 & 0.033 & 7.23 & 0.069 & 0.029 & 1.310 & 1.80 & 8.64 & 0.428 & 0.047 & 23.2 & $<0.100$ & 0.011 & 2.95 & 0.041 & 0.064 \\
\hline ADT-3 & A04LM11 & 2 & 1 & 6 & 2.97 & 0.042 & 0.737 & 0.047 & 0.051 & 0.034 & 7.62 & 0.073 & 0.029 & 0.712 & 1.85 & 10.7 & 0.426 & 0.047 & 22.2 & $<0.100$ & 0.010 & 3.02 & 0.042 & 0.061 \\
\hline \begin{tabular}{|l|} 
ADT-4 \\
\end{tabular} & 406LM11 & 2 & 1 & 7 & 3.39 & 0.049 & 0.802 & 0.065 & 0.052 & 0.037 & 8.73 & 0.085 & 0.034 & 0.787 & 2.08 & 11.2 & 0.479 & 0.053 & 20.8 & $<0.100$ & 0.012 & 3.37 & 0.047 & 0.069 \\
\hline ADT-4 & M21 & 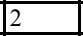 & 1 & 8 & 3.38 & 0.050 & 0.803 & 0.066 & 0.052 & 0.036 & 8.59 & 0.082 & 0.034 & 0.803 & 2.09 & 11.3 & 0.490 & 0.054 & 20.9 & $<0.100$ & 0.012 & 3.36 & 0.047 & 0.072 \\
\hline \begin{tabular}{|l|} 
ADT-5 \\
\end{tabular} & A08LM11 & 2 & 1 & 9 & 3.00 & 0.043 & 0.732 & 0.060 & 0.063 & 0.033 & 7.69 & 0.073 & 0.030 & 0.716 & 1.83 & 11.7 & 0.436 & 0.047 & 22.4 & $<0.100$ & 0.011 & 2.89 & 0.043 & 0.063 \\
\hline Batch 1 & CHLM212 & 2 & 1 & 10 & 2.59 & 0.128 & 0.860 & $<0.010$ & 0.076 & 0.302 & 8.74 & 2.57 & $<0.010$ & 0.818 & 1.32 & 6.80 & 0.552 & $<0.020$ & 23.8 & $<0.100$ & 0.392 & $<0.100$ & $<0.010$ & 0.078 \\
\hline Ustd & STDLM212 & 2 & 1 & 11 & 2.12 & $<0.010$ & 0.861 & $<0.010$ & 0.162 & 0.010 & 8.91 & 2.43 & $<0.010$ & 0.680 & 2.15 & 8.90 & 0.764 & $<0.020$ & 21.2 & $<0.100$ & 0.549 & 2.01 & $<0.010$ & $<0.010$ \\
\hline ADT-8 & A10LM11 & 2 & 1 & 12 & 3.30 & 0.050 & 0.805 & 0.033 & 0.060 & 0.040 & 8.37 & 0.074 & 0.034 & 0.802 & 2.07 & 12.9 & 0.494 & 0.053 & 20.6 & $<0.100$ & 0.012 & 3.37 & 0.048 & \begin{tabular}{|l|l|}
0.071 \\
\end{tabular} \\
\hline ADT-1 & $\sqrt{1}$ & 2 & 1 & 13 & 2.97 & 0.045 & 0.704 & 0.046 & 0.047 & 0.033 & 7.27 & 0.070 & 0.030 & 1.316 & 1.80 & 8.66 & 0.429 & 0.048 & 24.5 & \begin{tabular}{|c|}
$<0.100$ \\
\end{tabular} & 0.011 & 2.94 & 0.048 & 0.065 \\
\hline ADT-8 & A10LM21 & 2 & 1 & 14 & 3.42 & 0.050 & 0.823 & 0.034 & 0.064 & 0.045 & 8.50 & 0.079 & 0.035 & 0.814 & 2.10 & 13.3 & 0.504 & 0.053 & 21.2 & $<0.100$ & 0.013 & 3.47 & 0.049 & 0.072 \\
\hline ADT-5 & A08LM21 & 2 & 1 & 15 & 2.92 & 0.043 & 0.716 & 0.060 & 0.063 & 0.034 & 7.58 & 0.069 & 0.030 & 0.720 & 1.80 & 11.4 & 0.441 & 0.046 & 22.6 & $<0.100$ & 0.011 & 2.84 & 0.043 & 0.066 \\
\hline ADT-3 & & 2 & 4 & 16 & 2.96 & 0.044 & 0.722 & 0.050 & 0.052 & 0.034 & 7.60 & 0.066 & 0.031 & 0.734 & 1.83 & 10.5 & 0.449 & 0.049 & 23.2 & $<0.100$ & 0.011 & 3.03 & 0.045 & 0.064 \\
\hline VIS-4 & $\overline{12 \mathrm{MM}}$ & 2 & 1 & 17 & 3.16 & 0.047 & 0.753 & 0.056 & 0.072 & 0.037 & 8.10 & 0.073 & 0.031 & 0.748 & 1.96 & 9.91 & 0.451 & \begin{tabular}{|l|}
0.049 \\
\end{tabular} & 23.1 & $<0.100$ & 0.014 & 3.10 & 0.047 & 0.063 \\
\hline ADT-2 & & 2 & 1 & 18 & 3.34 & 0.051 & 0.800 & 0.051 & 0.050 & 0.037 & 8.31 & 0.075 & 0.034 & 1.367 & 2.08 & 9.27 & 0.489 & 0.055 & 22.5 & $<0.100$ & 0.012 & 3.43 & 0.047 & 0.071 \\
\hline Ustd & & 2 & 1 & 19 & 2.12 & $<0.010$ & 0.868 & $<0.010$ & 0.160 & 0.010 & 8.86 & 2.45 & $<0.010$ & 0.681 & \begin{tabular}{|l|}
2.13 \\
\end{tabular} & 8.77 & 0.756 & $<0.020$ & 21.6 & $<0.100$ & 0.547 & 1.98 & $<0.010$ & $<0.010$ \\
\hline Batch 1 & $\overline{\mathrm{CHLI}}$ & 2 & 1 & 20 & 2.62 & 0.129 & 0.865 & $<<0.010$ & 0.076 & 0.305 & 8.68 & 2.59 & $<0.010$ & 0.820 & 1.31 & 6.88 & 0.552 & $<0.020$ & 24.5 & $<0.100$ & 0.396 & $<0.100$ & $<0.010$ & 0.077 \\
\hline Batch 1 & B & 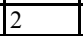 & 2 & 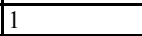 & 2.59 & 0.128 & 0.866 & $<0.010$ & 0.076 & 0.303 & 9.23 & 2.58 & $<0.010$ & 0.806 & \begin{tabular}{|l|}
1.38 \\
\end{tabular} & 6.60 & 0.548 & $<0.020$ & 24.0 & $<0.100$ & 0.385 & $<0.100$ & $<0.010$ & \begin{tabular}{|l|l|}
0.077 \\
\end{tabular} \\
\hline Ustd & & 2 & 2 & 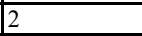 & 2.09 & $<0.010$ & 0.872 & $<0.010$ & 0.159 & 0.009 & 9.08 & 2.42 & $<0.010$ & 0.664 & 2.17 & 8.58 & 0.746 & $<0.020$ & 21.2 & \begin{tabular}{|c|}
$<0.100$ \\
\end{tabular} & 0.537 & 1.97 & $<0.010$ & $<0.010$ \\
\hline VIS-4 & t & 2 & 2 & 3 & 3.19 & 0.046 & 0.749 & 0.055 & 0.068 & 0.036 & 7.91 & 0.074 & 0.032 & 0.724 & 1.98 & 9.58 & 0.437 & 0.050 & 22.4 & $<0.100$ & 0.013 & 3.07 & 0.047 & 0.060 \\
\hline \begin{tabular}{|l|} 
VIS-4S \\
\end{tabular} & & 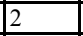 & 2 & 4 & 3.14 & 0.047 & 0.758 & 0.056 & 0.072 & 0.036 & 8.33 & 0.073 & 0.033 & 0.738 & 2.01 & 9.48 & 0.448 & 0.050 & 22.4 & \begin{tabular}{|c|c|}
$<00$ \\
\end{tabular} & 0.014 & 3.09 & 0.047 & 0.062 \\
\hline ADT-8 & $T_{2}$ & 2 & 2 & 5 & 3.30 & 0.049 & 0.807 & 0.033 & 0.061 & 0.039 & 8.38 & 0.074 & 0.035 & 0.796 & 2.06 & 12.4 & 0.494 & 0.054 & 20.2 & $<0.100$ & 0.012 & 3.36 & 0.048 & 0.071 \\
\hline $\mathrm{ADT}$ & & 2 & 2 & 6 & 2.92 & 0.044 & 0.700 & 0.046 & 0.046 & 0.032 & 7.28 & 0.067 & 0.030 & 1.291 & 1.79 & 8.14 & 0.427 & 0.048 & 23.5 & $<0.100$ & 0.012 & 2.89 & 0.041 & 0.064 \\
\hline ADT-3 & 404LM1 & 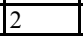 & 2 & 7 & 2.95 & 0.042 & 0.726 & 0.047 & 0.051 & 0.033 & 7.50 & 0.072 & 0.030 & 0.702 & 1.82 & 10.1 & 0.425 & 0.048 & 22.7 & $<0.100$ & 0.011 & 2.98 & 0.042 & 0.060 \\
\hline $\mathrm{ADT}$ & & 2 & 2 & 8 & 3.42 & 0.050 & 0.823 & 0.034 & 0.064 & 0.044 & 8.38 & 0.078 & 0.036 & 0.810 & 2.05 & 12.8 & 0.500 & 0.055 & 20.7 & $<0.100$ & 0.013 & 3.42 & 0.048 & 0.071 \\
\hline ADT-2 & & 2 & 2 & 9 & 3.31 & 0.050 & 0.832 & 0.047 & 0.050 & 0.036 & 8.37 & 0.079 & 0.035 & 1.347 & 2.07 & 8.67 & 0.484 & 0.055 & 22.9 & $<0.100$ & 0.013 & 3.34 & 0.072 & 0.070 \\
\hline Batch 1 & $\mathrm{HI}$ & 2 & 2 & 10 & 2.61 & \begin{tabular}{|l|}
0.129 \\
\end{tabular} & 0.857 & $<0.010$ & 0.076 & 0.301 & 8.85 & 2.57 & $<0.010$ & \begin{tabular}{|l|l|}
0.809 \\
\end{tabular} & 1.33 & 6.44 & 0.549 & $<0.020$ & 24.1 & $<0.100$ & 0.386 & $<0.100$ & $<0.010$ & \begin{tabular}{|l|l|}
0.077 \\
\end{tabular} \\
\hline Ustd & & 2 & 2 & 11 & 200 & $<<0.010$ & 0.873 & $<0.010$ & 0.161 & 0.009 & 9.18 & 2.42 & $<0.010$ & 0.673 & 2.20 & 8.21 & 0.756 & $<0.020$ & 21.3 & $<0.100$ & 0.540 & 1.96 & $<0.010$ & $<0.010$ \\
\hline ADT-2 & & 2 & 2 & 12 & 3.34 & 0.051 & 0.807 & 0.048 & 0.049 & 0.036 & 8.63 & 0.075 & 0.035 & 1.352 & 2.15 & 8.64 & 0.486 & 0.055 & 22.0 & $<0.100$ & 0.013 & 3.36 & 0.047 & 0.070 \\
\hline ADT-4 & $\mathrm{V}$ & 2 & 2 & 13 & 3.33 & 0.049 & 0.803 & 0.066 & 0.052 & 0.035 & 8.89 & 0.082 & 0.035 & 0.794 & 2.13 & 10.3 & 0.485 & 0.054 & 20.9 & \begin{tabular}{|c|c|} 
\\
\end{tabular} & 0.013 & 3.29 & 0.046 & 0.071 \\
\hline $\mathrm{ADT}$ & & 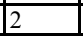 & 2 & 14 & 295 & 0.043 & 0.708 & 0.049 & 0.052 & 0.032 & 7.66 & 0.065 & 0.032 & \begin{tabular}{|l|l|}
0.729 \\
\end{tabular} & 1.84 & 9.92 & 0.446 & 0.050 & 22.8 & $<0.100$ & 0.011 & 2.97 & 0.044 & 0.063 \\
\hline ADT-5 & & 2 & 2 & 15 & 2.96 & 0.042 & 0.717 & 0.059 & 0.064 & 0.032 & 7.72 & 0.071 & 0.031 & 0.709 & 1.83 & 10.7 & 0.433 & 0.048 & 22.3 & \begin{tabular}{|c|c|}
$<00$ \\
\end{tabular} & 0.011 & 2.82 & 0.043 & 0.062 \\
\hline ADT-1 & & 2 & 2 & 16 & 2.92 & 0.044 & 0.698 & 0.046 & 0.047 & 0.031 & 7.38 & 0.068 & 0.030 & 1.291 & \begin{tabular}{|l|}
1.83 \\
\end{tabular} & 8.05 & 0.423 & 0.048 & 24.2 & $<0.100$ & 0.012 & 2.86 & 0.048 & 0.063 \\
\hline ADT-5 & & 2 & 2 & 17 & 291 & 0.043 & 0.725 & 0.060 & 0.063 & 0.033 & 7.84 & 0.068 & 0.031 & 0.714 & 1.85 & 10.6 & 0.438 & 0.048 & 22.0 & $<0.100$ & 0.011 & 2.78 & 0.042 & 0.064 \\
\hline ADT-4 & 06LM12 & 2 & 2 & 18 & 3.35 & 0.049 & 0.803 & 0.065 & 0.053 & 0.036 & 9.00 & 0.084 & 0.035 & 0.783 & 2.12 & 10.3 & 0.476 & 0.054 & 21.0 & $<0.100$ & 0.012 & 3.27 & 0.047 & 0.069 \\
\hline Ustd & & 2 & 2 & 19 & 2.10 & $<0.010$ & 0.876 & $<0.010$ & 0.161 & 0.009 & \begin{tabular}{|l|}
9.19 \\
\end{tabular} & 2.46 & $<0.010$ & 0.672 & 2.19 & 8.07 & 0.751 & $<0.020$ & 21.0 & $<0.100$ & 0.540 & 1.93 & $<0.010$ & $<0.010$ \\
\hline Batch 1 & BCHLM223 & 2 & 2 & 20 & 2.58 & 0.128 & 0.858 & $<0.010$ & 0.076 & 0.302 & 9.18 & 2.57 & $<0.010$ & 0.807 & 1.38 & 6.27 & 0.548 & $<0.020$ & 24.0 & \begin{tabular}{|c|}
$<0.100$ \\
\end{tabular} & 0.385 & $<0.100$ & $<0.010$ & 0.076 \\
\hline
\end{tabular}


Table D3. Measured Elemental Concentrations (wt\%) for Samples Prepared Using Peroxide Fusion

\begin{tabular}{|c|c|c|c|c|c|c|}
\hline Glass & SRNL-ML & & Sub & Analytical & & \\
\hline ID & ID & Block & Block & Sequence & B & $\mathbf{L i}$ \\
\hline Batch 1 & BCHPF111 & 1 & 1 & 1 & 2.47 & 1.98 \\
\hline Ustd & USTDPF111 & 1 & 1 & 2 & 2.91 & 1.41 \\
\hline ADT-3 & VA04PF11 & 1 & 1 & 3 & 1.63 & 2.35 \\
\hline VIS-4 & VA12PF11 & 1 & 1 & 4 & 1.56 & 2.32 \\
\hline ADT-4 & VA06PF21 & 1 & 1 & 5 & 1.45 & 2.18 \\
\hline ADT-3 & VA04PF21 & 1 & 1 & 6 & 1.56 & 2.36 \\
\hline VIS-3 & VA09PF11 & 1 & 1 & 7 & 1.56 & 2.39 \\
\hline VIS-4 & VA12PF21 & 1 & 1 & 8 & 1.52 & 2.31 \\
\hline VIS-5 & VA01PF11 & 1 & 1 & 9 & 1.43 & 2.23 \\
\hline Batch 1 & BCHPF112 & 1 & 1 & 10 & 2.31 & 2.03 \\
\hline Ustd & USTDPF112 & 1 & 1 & 11 & 2.73 & 1.43 \\
\hline ADT-6 & VA07PF11 & 1 & 1 & 12 & 1.50 & 2.15 \\
\hline ADT-6 & VA07PF21 & 1 & 1 & 13 & 1.42 & 2.18 \\
\hline ADT-8 & VA10PF11 & 1 & 1 & 14 & 1.41 & 1.39 \\
\hline ADT-4 & VA06PF11 & 1 & 1 & 15 & 1.39 & 2.19 \\
\hline VIS-3 & VA09PF21 & 1 & 1 & 16 & 1.50 & 2.40 \\
\hline ADT-8 & VA10PF21 & 1 & 1 & 17 & 1.37 & 1.38 \\
\hline VIS-5 & VA01PF21 & 1 & 1 & 18 & 1.36 & 2.25 \\
\hline Ustd & USTDPF113 & 1 & 1 & 19 & 2.72 & 1.43 \\
\hline Batch 1 & BCHPF113 & 1 & 1 & 20 & 2.27 & 2.04 \\
\hline Batch 1 & BCHPF121 & 1 & 2 & 1 & 2.50 & 1.99 \\
\hline Ustd & USTDPF121 & 1 & 2 & 2 & 2.84 & 1.42 \\
\hline VIS-4 & VA12PF12 & 1 & 2 & 3 & 1.58 & 2.32 \\
\hline VIS-5 & VA01PF22 & 1 & 2 & 4 & 1.46 & 2.22 \\
\hline VIS-4 & VA12PF22 & 1 & 2 & 5 & 1.52 & 2.30 \\
\hline VIS-5 & VA01PF12 & 1 & 2 & 6 & 1.44 & 2.22 \\
\hline ADT-3 & VA04PF22 & 1 & 2 & 7 & 1.52 & 2.37 \\
\hline ADT-4 & VA06PF12 & 1 & 2 & 8 & 1.38 & 2.18 \\
\hline ADT-3 & VA04PF12 & 1 & 2 & 9 & 1.47 & 2.35 \\
\hline Batch 1 & BCHPF122 & 1 & 2 & 10 & 2.33 & 2.00 \\
\hline Ustd & USTDPF122 & 1 & 2 & 11 & 2.75 & 1.43 \\
\hline ADT-6 & VA07PF22 & 1 & 2 & 12 & 1.45 & 2.18 \\
\hline ADT-4 & VA06PF22 & 1 & 2 & 13 & 1.45 & 2.20 \\
\hline ADT-8 & VA10PF12 & 1 & 2 & 14 & 1.38 & 1.38 \\
\hline ADT-6 & VA07PF12 & 1 & 2 & 15 & 1.38 & 2.14 \\
\hline VIS-3 & VA09PF12 & 1 & 2 & 16 & 1.49 & 2.40 \\
\hline VIS-3 & VA09PF22 & 1 & 2 & 17 & 1.47 & 2.39 \\
\hline ADT-8 & VA10PF22 & 1 & 2 & 18 & 1.38 & 1.38 \\
\hline Ustd & USTDPF 123 & 1 & 2 & 19 & 2.70 & 1.43 \\
\hline Batch 1 & BCHPF123 & 1 & 2 & 20 & 2.27 & 2.01 \\
\hline Batch 1 & BCHPF211 & 2 & 1 & 1 & 2.54 & 2.01 \\
\hline Ustd & USTDPF211 & 2 & 1 & 2 & 2.96 & 1.44 \\
\hline ADT-7 & VA02PF11 & 2 & 1 & 3 & 1.66 & 1.49 \\
\hline ADT-2 & VA13PF21 & 2 & 1 & 4 & 1.54 & 1.97 \\
\hline VIS-1 & VA11PF21 & 2 & 1 & 5 & 1.69 & 2.55 \\
\hline ADT-5 & VA08PF21 & 2 & 1 & 6 & 1.56 & 2.33 \\
\hline VIS-2 & VA05PF21 & 2 & 1 & 7 & 1.60 & 2.47 \\
\hline ADT-1 & VA03PF21 & 2 & 1 & 8 & 1.55 & 2.08 \\
\hline VIS-6 & VA14PF11 & 2 & 1 & 9 & 1.33 & 2.05 \\
\hline Batch 1 & BCHPF212 & 2 & 1 & 10 & 2.34 & 2.00 \\
\hline Ustd & USTDPF212 & 2 & 1 & 11 & 2.81 & 1.46 \\
\hline ADT-5 & VA08PF11 & 2 & 1 & 12 & 1.80 & 2.66 \\
\hline ADT-7 & VA02PF21 & 2 & 1 & 13 & 1.63 & 1.52 \\
\hline VIS-6 & VA14PF21 & 2 & 1 & 14 & 1.35 & 2.05 \\
\hline VIS-2 & VA05PF11 & 2 & 1 & 15 & 1.62 & 2.49 \\
\hline VIS-1 & VA11PF11 & 2 & 1 & 16 & 1.67 & 2.58 \\
\hline ADT-2 & VA13PF11 & 2 & 1 & 17 & 1.45 & 1.97 \\
\hline ADT-1 & VA03PF11 & 2 & 1 & 18 & 1.56 & 2.12 \\
\hline Ustd & USTDPF213 & 2 & 1 & 19 & 2.82 & 1.43 \\
\hline Batch 1 & BCHPF213 & 2 & 1 & 20 & 2.34 & 2.02 \\
\hline Batch 1 & BCHPF213 & 2 & 2 & 1 & 2.61 & 2.01 \\
\hline Ustd & USTDPF213 & 2 & 2 & 2 & 3.02 & 1.44 \\
\hline VIS-1 & VA11PF22 & 2 & 2 & 3 & 1.84 & 2.57 \\
\hline VIS-2 & VA05PF12 & 2 & 2 & 4 & 1.76 & 2.50 \\
\hline VIS-6 & VA14PF22 & 2 & 2 & 5 & 1.47 & 2.06 \\
\hline ADT-5 & VA08PF22 & 2 & 2 & 6 & 1.66 & 2.34 \\
\hline
\end{tabular}


Table D3. Measured Elemental Concentrations (wt\%) for Samples Prepared Using Peroxide Fusion

\begin{tabular}{||c|c|c|c|c|c|c||}
\hline Glass & SRNL-ML & & Sub & Analytical & & \\
\hline ID & ID & Block & Block & Sequence & B & Li \\
\hline ADT-2 & VA13PF12 & 2 & 2 & 7 & 1.57 & 1.99 \\
\hline ADT-1 & VA03PF12 & 2 & 2 & 8 & 1.67 & 2.12 \\
\hline ADT-7 & VA02PF22 & 2 & 2 & 9 & 1.67 & 1.53 \\
\hline Batch 1 & BCHPF222 & 2 & 2 & 10 & 2.49 & 2.03 \\
\hline Ustd & USTDPF222 & 2 & 2 & 11 & 2.98 & 1.45 \\
\hline ADT-1 & VA03PF22 & 2 & 2 & 12 & 1.72 & 2.11 \\
\hline VIS-2 & VA05PF22 & 2 & 2 & 13 & 1.77 & 2.52 \\
\hline ADT-2 & VA13PF22 & 2 & 2 & 14 & 1.58 & 2.01 \\
\hline VIS-6 & VA14PF12 & 2 & 2 & 15 & 1.43 & 2.10 \\
\hline VIS-1 & VA11PF12 & 2 & 2 & 16 & 1.83 & 2.63 \\
\hline ADT-5 & VA08PF12 & 2 & 2 & 17 & 1.71 & 2.44 \\
\hline ADT-7 & VA02PF12 & 2 & 2 & 18 & 1.67 & 1.53 \\
\hline Ustd & USTDPF223 & 2 & 2 & 19 & 3.00 & 1.49 \\
\hline Batch 1 & BCHPF223 & 2 & 2 & 20 & 2.54 & 2.06 \\
\hline
\end{tabular}


Table D4. Average Measured and Bias-Corrected Chemical Compositions Versus Targeted Compositions by Oxide by VIS Glass Number

(100-Batch 1 and 101-Ustd)

\begin{tabular}{|c|c|c|c|c|c|c|c|c|c|}
\hline Glass \# & Glass ID & Oxide & $\begin{array}{c}\text { Measured } \\
(w t \%)\end{array}$ & $\begin{array}{c}\text { Measured } \\
\text { Bias-Corrected } \\
\text { (wt } \%)\end{array}$ & $\begin{array}{c}\text { Targeted } \\
\text { (wt\%) }\end{array}$ & $\begin{array}{c}\text { Diff of } \\
\text { Measured }\end{array}$ & $\begin{array}{c}\text { Diff of } \\
\text { Meas BC }\end{array}$ & $\begin{array}{l}\text { \% Diff of } \\
\text { Measured }\end{array}$ & $\begin{array}{l}\% \text { Diff of } \\
\text { Meas BC }\end{array}$ \\
\hline 100 & Batch 1 & Al2O3 (wt\%) & 4.9033 & 4.8770 & 4.8770 & 0.0263 & 0.0000 & $0.5 \%$ & $0.0 \%$ \\
\hline 100 & Batch 1 & $\mathrm{~B} 2 \mathrm{O} 3(\mathrm{wt} \%)$ & 7.7841 & 7.7770 & 7.7770 & 0.0071 & 0.0000 & $0.1 \%$ & $0.0 \%$ \\
\hline 100 & Batch 1 & $\mathrm{BaO}(\mathrm{wt} \%)$ & 0.1433 & 0.1510 & 0.1510 & -0.0077 & 0.0000 & $-5.1 \%$ & $0.0 \%$ \\
\hline 100 & Batch 1 & $\mathrm{CaO}(\mathrm{wt} \%)$ & 1.2045 & 1.2200 & 1.2200 & -0.0155 & 0.0000 & $-1.3 \%$ & $0.0 \%$ \\
\hline 100 & Batch 1 & $\mathrm{Ce} 2 \mathrm{O} 3(\mathrm{wt} \%)$ & 0.0059 & 0.0059 & 0.0000 & 0.0059 & 0.0059 & & \\
\hline 100 & Batch 1 & $\mathrm{Cr} 2 \mathrm{O} 3(\mathrm{wt} \%)$ & 0.1113 & 0.1070 & 0.1070 & 0.0043 & 0.0000 & $4.0 \%$ & $0.0 \%$ \\
\hline 100 & Batch 1 & $\mathrm{CuO}(\mathrm{wt} \%)$ & 0.3787 & 0.3990 & 0.3990 & -0.0203 & 0.0000 & $-5.1 \%$ & $0.0 \%$ \\
\hline 100 & Batch 1 & $\mathrm{Fe} 2 \mathrm{O} 3(\mathrm{wt} \%)$ & 12.6624 & 12.8390 & 12.8390 & -0.1766 & 0.0000 & $-1.4 \%$ & $0.0 \%$ \\
\hline 100 & Batch 1 & $\mathrm{~K} 2 \mathrm{O}(\mathrm{wt} \%)$ & 3.1039 & 3.3270 & 3.3270 & -0.2231 & 0.0000 & $-6.7 \%$ & $0.0 \%$ \\
\hline 100 & Batch 1 & La2O3 (wt\%) & 0.0059 & 0.0059 & 0.0000 & 0.0059 & 0.0059 & & \\
\hline 100 & Batch 1 & $\mathrm{Li} 2 \mathrm{O}(\mathrm{wt} \%)$ & 4.3381 & 4.4290 & 4.4290 & -0.0909 & 0.0000 & $-2.1 \%$ & $0.0 \%$ \\
\hline 100 & Batch 1 & $\mathrm{MgO}(\mathrm{wt} \%)$ & 1.3516 & 1.4190 & 1.4190 & -0.0674 & 0.0000 & $-4.7 \%$ & $0.0 \%$ \\
\hline 100 & Batch 1 & $\mathrm{MnO}(\mathrm{wt} \%)$ & 1.7238 & 1.7260 & 1.7260 & -0.0022 & 0.0000 & $-0.1 \%$ & $0.0 \%$ \\
\hline 100 & Batch 1 & $\mathrm{Na} 2 \mathrm{O}(\mathrm{wt} \%)$ & 9.0417 & 9.0030 & 9.0030 & 0.0387 & 0.0000 & $0.4 \%$ & $0.0 \%$ \\
\hline 100 & Batch 1 & $\mathrm{NiO}(w t \%)$ & 0.7002 & 0.7510 & 0.7510 & -0.0508 & 0.0000 & $-6.8 \%$ & $0.0 \%$ \\
\hline 100 & Batch 1 & $\mathrm{PbO}(\mathrm{wt} \%)$ & 0.0108 & 0.0108 & 0.0000 & 0.0108 & 0.0108 & & \\
\hline 100 & Batch 1 & $\mathrm{SiO} 2(\mathrm{wt} \%)$ & 51.3432 & 50.2200 & 50.2200 & 1.1232 & 0.0000 & $2.2 \%$ & $0.0 \%$ \\
\hline 100 & Batch 1 & ThO2 (wt $\%)$ & 0.0569 & 0.0569 & 0.0000 & 0.0569 & 0.0569 & & \\
\hline 100 & Batch 1 & $\mathrm{TiO} 2(w t \%)$ & 0.6508 & 0.6770 & 0.6770 & -0.0262 & 0.0000 & $-3.9 \%$ & $0.0 \%$ \\
\hline 100 & Batch 1 & U3O8 (wt\%) & 0.0590 & 0.0609 & 0.0000 & 0.0590 & 0.0609 & & \\
\hline 100 & Batch 1 & $\mathrm{ZnO}(\mathrm{wt} \%)$ & 0.0062 & 0.0062 & 0.0000 & 0.0062 & 0.0062 & & \\
\hline 100 & Batch 1 & $\mathrm{ZrO} 2(\mathrm{wt} \%)$ & 0.1036 & 0.1036 & 0.0980 & 0.0056 & 0.0056 & $5.7 \%$ & $5.7 \%$ \\
\hline 100 & Batch 1 & Sum of Oxides & 99.6889 & 99.1721 & 99.0200 & 0.6689 & 0.1521 & $0.7 \%$ & $0.2 \%$ \\
\hline 101 & Ustd & $\mathrm{A} 12 \mathrm{O} 3(\mathrm{wt} \%)$ & 3.9522 & 3.9311 & 4.1000 & -0.1478 & -0.1689 & $-3.6 \%$ & $-4.1 \%$ \\
\hline 101 & Ustd & $\mathrm{B} 2 \mathrm{O} 3(\mathrm{wt} \%)$ & 9.1874 & 9.1792 & 9.2090 & -0.0216 & -0.0298 & $-0.2 \%$ & $-0.3 \%$ \\
\hline 101 & Ustd & $\mathrm{BaO}(\mathrm{wt} \%)$ & 0.0056 & 0.0059 & 0.0000 & 0.0056 & 0.0059 & & \\
\hline 101 & Ustd & $\mathrm{CaO}(\mathrm{wt} \%)$ & 1.2187 & 1.2344 & 1.3010 & -0.0823 & -0.0666 & $-6.3 \%$ & $-5.1 \%$ \\
\hline 101 & Ustd & $\mathrm{Ce} 2 \mathrm{O} 3(\mathrm{wt} \%)$ & 0.0059 & 0.0059 & 0.0000 & 0.0059 & 0.0059 & & \\
\hline 101 & Ustd & $\mathrm{Cr} 2 \mathrm{O} 3(\mathrm{wt} \%)$ & 0.2345 & 0.2254 & 0.0000 & 0.2345 & 0.2254 & & \\
\hline 101 & Ustd & $\mathrm{CuO}(\mathrm{wt} \%)$ & 0.0125 & 0.0132 & 0.0000 & 0.0125 & 0.0132 & & \\
\hline 101 & Ustd & Fe2O3 (wt\%) & 12.9257 & 13.1074 & 13.1960 & -0.2703 & -0.0886 & $-2.0 \%$ & $-0.7 \%$ \\
\hline 101 & Ustd & $\mathrm{K} 2 \mathrm{O}(\mathrm{wt} \%)$ & 2.9452 & 3.1571 & 2.9990 & -0.0538 & 0.1581 & $-1.8 \%$ & $5.3 \%$ \\
\hline 101 & Ustd & La2O3 (wt\%) & 0.0059 & 0.0059 & 0.0000 & 0.0059 & 0.0059 & & \\
\hline 101 & Ustd & $\mathrm{Li} 2 \mathrm{O}(w \mathrm{t} \%)$ & 3.0966 & 3.1615 & 3.0570 & 0.0396 & 0.1045 & $1.3 \%$ & $3.4 \%$ \\
\hline 101 & Ustd & $\mathrm{MgO}(\mathrm{wt} \%)$ & 1.1199 & 1.1757 & 1.2100 & -0.0901 & -0.0343 & $-7.4 \%$ & $-2.8 \%$ \\
\hline 101 & Ustd & $\mathrm{MnO}(\mathrm{wt} \%)$ & 2.7987 & 2.8026 & 2.8920 & -0.0933 & -0.0894 & $-3.2 \%$ & $-3.1 \%$ \\
\hline 101 & Ustd & $\mathrm{Na} 2 \mathrm{O}(\mathrm{wt} \%)$ & 11.6647 & 11.6145 & 11.7950 & -0.1303 & -0.1805 & $-1.1 \%$ & $-1.5 \%$ \\
\hline 101 & Ustd & $\mathrm{NiO}\left(w t^{\circ} \%\right)$ & 0.9626 & 1.0325 & 1.1200 & -0.1574 & -0.0875 & $-14.0 \%$ & $-7.8 \%$ \\
\hline 101 & Ustd & $\mathrm{PbO}(\mathrm{wt} \%)$ & 0.0108 & 0.0108 & 0.0000 & 0.0108 & 0.0108 & & \\
\hline 101 & Ustd & $\mathrm{SiO} 2(\mathrm{wt} \%)$ & 45.2997 & 44.3083 & 45.3530 & -0.0533 & -1.0447 & $-0.1 \%$ & $-2.3 \%$ \\
\hline 101 & Ustd & ThO2 (wt $\%)$ & 0.0569 & 0.0569 & 0.0000 & 0.0569 & 0.0569 & & \\
\hline 101 & Ustd & $\mathrm{TiO} 2(w t \%)$ & 0.9089 & 0.9455 & 1.0490 & -0.1401 & -0.1035 & $-13.4 \%$ & $-9.9 \%$ \\
\hline 101 & Ustd & U3O8 (wt\%) & 2.3279 & 2.4060 & 2.4060 & -0.0781 & 0.0000 & $-3.2 \%$ & $0.0 \%$ \\
\hline
\end{tabular}


Table D4. Average Measured and Bias-Corrected Chemical Compositions Versus Targeted Compositions by Oxide by VIS Glass Number

(100-Batch 1 and 101-U std)

\begin{tabular}{|c|c|c|c|c|c|c|c|c|c|}
\hline Glass \# & Glass ID & Oxide & $\begin{array}{c}\text { Measured } \\
(\mathbf{w t} \%)\end{array}$ & $\begin{array}{c}\text { Measured } \\
\text { Bias-Corrected } \\
(\mathbf{w t} \%)\end{array}$ & $\begin{array}{l}\text { Targeted } \\
(\mathbf{w t} \%)\end{array}$ & $\begin{array}{c}\text { Diff of } \\
\text { Measured }\end{array}$ & $\begin{array}{c}\text { Diff of } \\
\text { Meas BC }\end{array}$ & $\begin{array}{l}\% \text { Diff of } \\
\text { Measured }\end{array}$ & $\begin{array}{l}\% \text { Diff of } \\
\text { Meas BC }\end{array}$ \\
\hline 101 & Ustd & $\mathrm{ZnO}(\mathrm{wt} \%)$ & 0.0062 & 0.0062 & 0.0000 & 0.0062 & 0.0062 & & \\
\hline 101 & Ustd & $\mathrm{ZrO} 2(\mathrm{wt} \%)$ & 0.0068 & 0.0068 & 0.0000 & 0.0068 & 0.0068 & & \\
\hline 101 & Ustd & Sum of Oxides & 98.7533 & 98.3925 & 99.6870 & -0.9337 & -1.2945 & $-0.9 \%$ & $-1.3 \%$ \\
\hline 1 & VIS-1 & $\mathrm{Al} 2 \mathrm{O} 3(\mathrm{wt} \%)$ & 4.8135 & 4.7909 & 4.5931 & 0.2204 & 0.1978 & $4.8 \%$ & $4.3 \%$ \\
\hline 1 & VIS-1 & $\mathrm{B} 2 \mathrm{O} 3(\mathrm{wt} \%)$ & 5.6590 & 5.5163 & 5.6000 & 0.0590 & -0.0837 & $1.1 \%$ & $-1.5 \%$ \\
\hline 1 & VIS-1 & $\mathrm{BaO}(\mathrm{wt} \%)$ & 0.0441 & 0.0465 & 0.0444 & -0.0003 & 0.0021 & $-0.7 \%$ & $4.7 \%$ \\
\hline 1 & VIS-1 & $\mathrm{CaO}(\mathrm{wt} \%)$ & 0.8570 & 0.8669 & 0.8728 & -0.0158 & -0.0059 & $-1.8 \%$ & $-0.7 \%$ \\
\hline 1 & VIS-1 & $\mathrm{Ce} 2 \mathrm{O} 3(\mathrm{wt} \%)$ & 0.0600 & 0.0600 & 0.0716 & -0.0116 & -0.0116 & $-16.2 \%$ & $-16.2 \%$ \\
\hline 1 & VIS-1 & $\mathrm{Cr} 2 \mathrm{O} 3(\mathrm{wt} \%)$ & 0.0683 & 0.0655 & 0.0715 & -0.0032 & -0.0060 & $-4.4 \%$ & $-8.4 \%$ \\
\hline 1 & VIS-1 & $\mathrm{CuO}(\mathrm{wt} \%)$ & 0.0385 & 0.0405 & 0.0268 & 0.0117 & 0.0137 & $43.6 \%$ & $51.2 \%$ \\
\hline 1 & VIS-1 & $\mathrm{Fe} 2 \mathrm{O} 3(\mathrm{wt} \%)$ & 9.3038 & 9.5033 & 9.8089 & -0.5051 & -0.3056 & $-5.1 \%$ & $-3.1 \%$ \\
\hline 1 & VIS-1 & $\mathrm{K} 2 \mathrm{O}(\mathrm{wt} \%)$ & 0.0720 & 0.0771 & 0.0626 & 0.0094 & 0.0145 & $15.0 \%$ & $23.2 \%$ \\
\hline 1 & VIS-1 & $\mathrm{La} 2 \mathrm{O} 3(\mathrm{wt} \%)$ & 0.0320 & 0.0320 & 0.0349 & -0.0029 & -0.0029 & $-8.4 \%$ & $-8.4 \%$ \\
\hline 1 & VIS-1 & Li2O (wt\%) & 5.5599 & 5.6576 & 5.6000 & -0.0401 & 0.0576 & $-0.7 \%$ & $1.0 \%$ \\
\hline 1 & VIS-1 & $\mathrm{MgO}(\mathrm{wt} \%)$ & 1.0425 & 1.0900 & 1.0698 & -0.0273 & 0.0202 & $-2.5 \%$ & $1.9 \%$ \\
\hline 1 & VIS-1 & $\mathrm{MnO}(\mathrm{wt} \%)$ & 2.0659 & 2.0816 & 2.0056 & 0.0603 & 0.0760 & $3.0 \%$ & $3.8 \%$ \\
\hline 1 & VIS-1 & $\mathrm{Na} 2 \mathrm{O}(\mathrm{wt} \%)$ & 12.1826 & 11.9892 & 12.2072 & -0.0246 & -0.2180 & $-0.2 \%$ & $-1.8 \%$ \\
\hline 1 & VIS-1 & $\mathrm{NiO}(\mathrm{wt} \%)$ & 0.4921 & 0.5273 & 0.5292 & -0.0371 & -0.0019 & $-7.0 \%$ & $-0.4 \%$ \\
\hline 1 & VIS-1 & $\mathrm{PbO}(\mathrm{wt} \%)$ & 0.0466 & 0.0466 & 0.0428 & 0.0038 & 0.0038 & $8.9 \%$ & $8.9 \%$ \\
\hline 1 & VIS-1 & $\mathrm{SiO} 2(\mathrm{wt} \%)$ & 53.5895 & 52.5633 & 54.1289 & -0.5394 & -1.5656 & $-1.0 \%$ & $-2.9 \%$ \\
\hline 1 & VIS-1 & ThO2 (wt $\%)$ & 0.0569 & 0.0569 & 0.0104 & 0.0465 & 0.0465 & $447.1 \%$ & $447.1 \%$ \\
\hline 1 & VIS-1 & $\mathrm{TiO} 2(w t \%)$ & 0.0175 & 0.0182 & 0.0102 & 0.0073 & 0.0080 & $71.7 \%$ & $78.0 \%$ \\
\hline 1 & VIS-1 & U3O8 (wt\%) & 2.9156 & 3.0121 & 3.0828 & -0.1672 & -0.0707 & $-5.4 \%$ & $-2.3 \%$ \\
\hline 1 & VIS-1 & $\mathrm{ZnO}(\mathrm{wt} \%)$ & 0.0520 & 0.0520 & 0.0457 & 0.0063 & 0.0063 & $13.7 \%$ & $13.7 \%$ \\
\hline 1 & VIS-1 & $\mathrm{ZrO} 2(\mathrm{wt} \%)$ & 0.0746 & 0.0746 & 0.0799 & -0.0053 & -0.0053 & $-6.6 \%$ & $-6.6 \%$ \\
\hline 1 & VIS-1 & Sum of Oxides & 99.0438 & 98.1684 & 99.9991 & -0.9553 & -1.8307 & $-1.0 \%$ & $-1.8 \%$ \\
\hline 2 & VIS-2 & $\mathrm{Al} 2 \mathrm{O} 3(\mathrm{wt} \%)$ & 5.2859 & 5.2612 & 5.0524 & 0.2335 & 0.2088 & $4.6 \%$ & $4.1 \%$ \\
\hline 2 & VIS-2 & $\mathrm{B} 2 \mathrm{O} 3(\mathrm{wt} \%)$ & 5.4336 & 5.2963 & 5.3600 & 0.0736 & -0.0637 & $1.4 \%$ & $-1.2 \%$ \\
\hline 2 & VIS-2 & $\mathrm{BaO}(\mathrm{wt} \%)$ & 0.0455 & 0.0479 & 0.0488 & -0.0033 & -0.0009 & $-6.8 \%$ & $-1.8 \%$ \\
\hline 2 & VIS-2 & $\mathrm{CaO}(\mathrm{wt} \%)$ & 0.9438 & 0.9546 & 0.9601 & -0.0163 & -0.0055 & $-1.7 \%$ & $-0.6 \%$ \\
\hline 2 & VIS-2 & $\mathrm{Ce} 2 \mathrm{O} 3(\mathrm{wt} \%)$ & 0.0562 & 0.0562 & 0.0788 & -0.0226 & -0.0226 & $-28.7 \%$ & $-28.7 \%$ \\
\hline 2 & VIS-2 & $\mathrm{Cr} 2 \mathrm{O} 3(\mathrm{wt} \%)$ & 0.0716 & 0.0687 & 0.0787 & -0.0071 & -0.0100 & $-9.0 \%$ & $-12.7 \%$ \\
\hline 2 & VIS-2 & $\mathrm{CuO}(\mathrm{wt} \%)$ & 0.0419 & 0.0441 & 0.0295 & 0.0124 & 0.0146 & $42.2 \%$ & $49.6 \%$ \\
\hline 2 & VIS-2 & $\mathrm{Fe} 2 \mathrm{O} 3(\mathrm{wt} \%)$ & 9.8471 & 10.0582 & 10.7908 & -0.9437 & -0.7326 & $-8.7 \%$ & $-6.8 \%$ \\
\hline 2 & VIS-2 & $\mathrm{K} 2 \mathrm{O}(\mathrm{wt} \%)$ & 0.0849 & 0.0910 & 0.0689 & 0.0160 & 0.0221 & $23.3 \%$ & $32.1 \%$ \\
\hline 2 & VIS-2 & La2O3 (wt\%) & 0.0346 & 0.0346 & 0.0384 & -0.0038 & -0.0038 & $-9.9 \%$ & $-9.9 \%$ \\
\hline 2 & VIS-2 & Li2O (wt\%) & 5.3715 & 5.4660 & 5.3600 & 0.0115 & 0.1060 & $0.2 \%$ & $2.0 \%$ \\
\hline 2 & VIS-2 & $\mathrm{MgO}(\mathrm{wt} \%)$ & 1.0836 & 1.1329 & 1.1767 & -0.0931 & -0.0438 & $-7.9 \%$ & $-3.7 \%$ \\
\hline 2 & VIS-2 & $\mathrm{MnO}(\mathrm{wt} \%)$ & 2.2499 & 2.2670 & 2.2062 & 0.0437 & 0.0608 & $2.0 \%$ & $2.8 \%$ \\
\hline 2 & VIS-2 & $\mathrm{Na} 2 \mathrm{O}(\mathrm{wt} \%)$ & 12.6914 & 12.4903 & 12.6279 & 0.0635 & -0.1376 & $0.5 \%$ & $-1.1 \%$ \\
\hline 2 & VIS-2 & $\mathrm{NiO}(\mathrm{wt} \%)$ & 0.5014 & 0.5372 & 0.5821 & -0.0807 & -0.0449 & $-13.9 \%$ & $-7.7 \%$ \\
\hline 2 & VIS-2 & $\mathrm{PbO}(\mathrm{wt} \%)$ & 0.0452 & 0.0452 & 0.0471 & -0.0019 & -0.0019 & $-3.9 \%$ & $-3.9 \%$ \\
\hline 2 & VIS-2 & $\mathrm{SiO} 2(\mathrm{wt} \%)$ & 50.8619 & 49.8891 & 51.9418 & -1.0799 & -2.0527 & $-2.1 \%$ & $-4.0 \%$ \\
\hline 2 & VIS-2 & ThO2 (wt\%) & 0.0569 & 0.0569 & 0.0115 & 0.0454 & 0.0454 & $394.7 \%$ & $394.7 \%$ \\
\hline
\end{tabular}


Table D4. Average Measured and Bias-Corrected Chemical Compositions Versus Targeted Compositions by Oxide by VIS Glass Number

(100-Batch 1 and 101-Ustd)

\begin{tabular}{|c|c|c|c|c|c|c|c|c|c|}
\hline Glass \# & Glass ID & Oxide & $\begin{array}{c}\text { Measured } \\
(\mathbf{w t} \%) \\
\end{array}$ & $\begin{array}{c}\text { Measured } \\
\text { Bias-Corrected } \\
(\mathbf{w t} \%) \\
\end{array}$ & $\begin{array}{c}\text { Targeted } \\
(\mathbf{w t} \%)\end{array}$ & $\begin{array}{c}\text { Diff of } \\
\text { Measured }\end{array}$ & $\begin{array}{c}\text { Diff of } \\
\text { Meas BC } \\
\end{array}$ & $\begin{array}{l}\% \text { Diff of } \\
\text { Measured }\end{array}$ & $\begin{array}{l}\text { \% Diff of } \\
\text { Meas BC }\end{array}$ \\
\hline 2 & VIS-2 & TiO2 $(w t \%)$ & 0.0192 & 0.0199 & 0.0112 & 0.0080 & 0.0087 & $71.3 \%$ & $77.6 \%$ \\
\hline 2 & VIS-2 & U3O8 (wt\%) & 3.2664 & 3.3746 & 3.3911 & -0.1247 & -0.0165 & $-3.7 \%$ & $-0.5 \%$ \\
\hline 2 & VIS-2 & $\mathrm{ZnO}(\mathrm{wt} \%)$ & 0.0504 & 0.0504 & 0.0502 & 0.0002 & 0.0002 & $0.4 \%$ & $0.4 \%$ \\
\hline 2 & VIS-2 & $\mathrm{ZrO} 2(\mathrm{wt} \%)$ & 0.0773 & 0.0773 & 0.0878 & -0.0105 & -0.0105 & $-11.9 \%$ & $-11.9 \%$ \\
\hline 2 & VIS-2 & Sum of Oxides & 98.1201 & 97.3198 & 100.0000 & -1.8799 & -2.6802 & $-1.9 \%$ & $-2.7 \%$ \\
\hline 3 & VIS-3 & $\mathrm{A} 12 \mathrm{O} 3(\mathrm{wt} \%)$ & 5.6874 & 5.6606 & 5.3586 & 0.3288 & 0.3020 & $6.1 \%$ & $5.6 \%$ \\
\hline 3 & VIS-3 & $\mathrm{B} 2 \mathrm{O} 3(\mathrm{wt} \%)$ & 4.8459 & 4.9633 & 5.2000 & -0.3541 & -0.2367 & $-6.8 \%$ & $-4.6 \%$ \\
\hline 3 & VIS-3 & $\mathrm{BaO}(\mathrm{wt} \%)$ & 0.0530 & 0.0559 & 0.0518 & 0.0012 & 0.0041 & $2.4 \%$ & $7.9 \%$ \\
\hline 3 & VIS-3 & $\mathrm{CaO}(\mathrm{wt} \%)$ & 1.0358 & 1.0477 & 1.0182 & 0.0176 & 0.0295 & $1.7 \%$ & $2.9 \%$ \\
\hline 3 & VIS-3 & $\mathrm{Ce} 2 \mathrm{O} 3(\mathrm{wt} \%)$ & 0.0635 & 0.0635 & 0.0835 & -0.0200 & -0.0200 & $-23.9 \%$ & $-23.9 \%$ \\
\hline 3 & VIS-3 & $\mathrm{Cr} 2 \mathrm{O} 3(\mathrm{wt} \%)$ & 0.0888 & 0.0852 & 0.0834 & 0.0054 & 0.0018 & $6.5 \%$ & $2.1 \%$ \\
\hline 3 & VIS-3 & $\mathrm{CuO}(\mathrm{wt} \%)$ & 0.0457 & 0.0481 & 0.0313 & 0.0144 & 0.0168 & $46.0 \%$ & $53.7 \%$ \\
\hline 3 & VIS-3 & $\mathrm{Fe} 2 \mathrm{O} 3(\mathrm{wt} \%)$ & 10.4690 & 10.6935 & 11.4448 & -0.9758 & -0.7513 & $-8.5 \%$ & $-6.6 \%$ \\
\hline 3 & VIS-3 & $\mathrm{K} 2 \mathrm{O}(\mathrm{wt} \%)$ & 0.0879 & 0.0942 & 0.0731 & 0.0148 & 0.0211 & $20.3 \%$ & $28.9 \%$ \\
\hline 3 & VIS-3 & $\mathrm{La} 2 \mathrm{O} 3(\mathrm{wt} \%)$ & 0.0367 & 0.0367 & 0.0408 & -0.0042 & -0.0042 & $-10.2 \%$ & $-10.2 \%$ \\
\hline 3 & VIS-3 & Li2O (wt\%) & 5.1562 & 5.2818 & 5.2000 & -0.0438 & 0.0818 & $-0.8 \%$ & $1.6 \%$ \\
\hline 3 & VIS-3 & $\mathrm{MgO}(\mathrm{wt} \%)$ & 1.1822 & 1.2361 & 1.2481 & -0.0659 & -0.0120 & $-5.3 \%$ & $-1.0 \%$ \\
\hline 3 & VIS-3 & $\mathrm{MnO}(\mathrm{wt} \%)$ & 2.4242 & 2.4427 & 2.3399 & 0.0843 & 0.1028 & $3.6 \%$ & $4.4 \%$ \\
\hline 3 & VIS-3 & $\mathrm{Na} 2 \mathrm{O}(\mathrm{wt} \%)$ & 13.0958 & 12.8875 & 12.9084 & 0.1874 & -0.0209 & $1.5 \%$ & $-0.2 \%$ \\
\hline 3 & VIS-3 & $\mathrm{NiO}(w t \%)$ & 0.5586 & 0.5985 & 0.6174 & -0.0588 & -0.0189 & $-9.5 \%$ & $-3.1 \%$ \\
\hline 3 & VIS-3 & $\mathrm{PbO}(\mathrm{wt} \%)$ & 0.0539 & 0.0539 & 0.0500 & 0.0039 & 0.0039 & $7.7 \%$ & $7.7 \%$ \\
\hline 3 & VIS-3 & $\mathrm{SiO} 2(\mathrm{wt} \%)$ & 50.7549 & 49.7842 & 50.4837 & 0.2712 & -0.6995 & $0.5 \%$ & $-1.4 \%$ \\
\hline 3 & VIS-3 & ThO2 (wt $\%)$ & 0.0569 & 0.0569 & 0.0122 & 0.0447 & 0.0447 & $366.4 \%$ & $366.4 \%$ \\
\hline 3 & VIS-3 & $\mathrm{TiO} 2(w t \%)$ & 0.0204 & 0.0212 & 0.0119 & 0.0085 & 0.0093 & $71.7 \%$ & $78.0 \%$ \\
\hline 3 & VIS-3 & $\mathrm{U} 3 \mathrm{O} 8$ (wt\%) & 3.3401 & 3.4506 & 3.5966 & -0.2565 & -0.1460 & $-7.1 \%$ & $-4.1 \%$ \\
\hline 3 & VIS-3 & $\mathrm{ZnO}(\mathrm{wt} \%)$ & 0.0485 & 0.0485 & 0.0533 & -0.0048 & -0.0048 & $-8.9 \%$ & $-8.9 \%$ \\
\hline 3 & VIS-3 & $\mathrm{ZrO} 2(\mathrm{wt} \%)$ & 0.0848 & 0.0848 & 0.0932 & -0.0084 & -0.0084 & $-9.1 \%$ & $-9.1 \%$ \\
\hline 3 & VIS-3 & Sum of Oxides & 99.1903 & 98.6952 & 100.0002 & -0.8099 & -1.3050 & $-0.8 \%$ & $-1.3 \%$ \\
\hline 4 & VIS-4 & $\mathrm{A} 12 \mathrm{O} 3(\mathrm{wt} \%)$ & 5.9992 & 5.9632 & 5.6648 & 0.3344 & 0.2984 & $5.9 \%$ & $5.3 \%$ \\
\hline 4 & VIS-4 & $\mathrm{B} 2 \mathrm{O} 3(\mathrm{wt} \%)$ & 4.9747 & 5.0949 & 5.0400 & -0.0653 & 0.0549 & $-1.3 \%$ & $1.1 \%$ \\
\hline 4 & VIS-4 & $\mathrm{BaO}(\mathrm{wt} \%)$ & 0.0519 & 0.0547 & 0.0547 & -0.0028 & 0.0000 & $-5.1 \%$ & $0.0 \%$ \\
\hline 4 & VIS-4 & $\mathrm{CaO}(\mathrm{wt} \%)$ & 1.0518 & 1.0668 & 1.0764 & -0.0246 & -0.0096 & $-2.3 \%$ & $-0.9 \%$ \\
\hline 4 & VIS-4 & $\mathrm{Ce} 2 \mathrm{O} 3(\mathrm{wt} \%)$ & 0.0653 & 0.0653 & 0.0883 & -0.0230 & -0.0230 & $-26.0 \%$ & $-26.0 \%$ \\
\hline 4 & VIS-4 & $\mathrm{Cr} 2 \mathrm{O} 3(\mathrm{wt} \%)$ & 0.1027 & 0.0989 & 0.0882 & 0.0145 & 0.0107 & $16.4 \%$ & $12.1 \%$ \\
\hline 4 & VIS-4 & $\mathrm{CuO}(\mathrm{wt} \%)$ & 0.0457 & 0.0482 & 0.0330 & 0.0127 & 0.0152 & $38.5 \%$ & $46.1 \%$ \\
\hline 4 & VIS-4 & $\mathrm{Fe} 2 \mathrm{O} 3(\mathrm{wt} \%)$ & 11.5019 & 11.5794 & 12.0988 & -0.5969 & -0.5194 & $-4.9 \%$ & $-4.3 \%$ \\
\hline 4 & VIS-4 & $\mathrm{K} 2 \mathrm{O}(\mathrm{wt} \%)$ & 0.0888 & 0.0953 & 0.0773 & 0.0115 & 0.0180 & $14.9 \%$ & $23.3 \%$ \\
\hline 4 & VIS-4 & $\mathrm{La} 2 \mathrm{O} 3(\mathrm{wt} \%)$ & 0.0372 & 0.0372 & 0.0431 & -0.0059 & -0.0059 & $-13.6 \%$ & $-13.6 \%$ \\
\hline 4 & VIS-4 & $\mathrm{Li} 2 \mathrm{O}(\mathrm{wt} \%)$ & 4.9786 & 5.0998 & 5.0400 & -0.0614 & 0.0598 & $-1.2 \%$ & $1.2 \%$ \\
\hline 4 & VIS-4 & $\mathrm{MgO}(\mathrm{wt} \%)$ & 1.2199 & 1.2860 & 1.3194 & -0.0995 & -0.0334 & $-7.5 \%$ & $-2.5 \%$ \\
\hline 4 & VIS-4 & $\mathrm{MnO}(\mathrm{wt} \%)$ & 2.5663 & 2.5541 & 2.4736 & 0.0927 & 0.0805 & $3.7 \%$ & $3.3 \%$ \\
\hline 4 & VIS-4 & $\mathrm{Na} 2 \mathrm{O}(\mathrm{wt} \%)$ & 13.1026 & 13.2059 & 13.1889 & -0.0863 & 0.0170 & $-0.7 \%$ & $0.1 \%$ \\
\hline 4 & VIS-4 & $\mathrm{NiO}(\mathrm{wt} \%)$ & 0.5659 & 0.6077 & 0.6526 & -0.0867 & -0.0449 & $-13.3 \%$ & $-6.9 \%$ \\
\hline 4 & VIS-4 & $\mathrm{PbO}(\mathrm{wt} \%)$ & 0.0533 & 0.0533 & 0.0528 & 0.0005 & 0.0005 & $1.0 \%$ & $1.0 \%$ \\
\hline
\end{tabular}


Table D4. Average Measured and Bias-Corrected Chemical Compositions Versus Targeted Compositions by Oxide by VIS Glass Number

(100-Batch 1 and 101-Ustd)

\begin{tabular}{|c|c|c|c|c|c|c|c|c|c|}
\hline Glass \# & Glass ID & Oxide & $\begin{array}{c}\text { Measured } \\
(\mathbf{w t} \%) \\
\end{array}$ & $\begin{array}{c}\text { Measured } \\
\text { Bias-Corrected } \\
(\mathbf{w t} \%) \\
\end{array}$ & $\begin{array}{c}\text { Targeted } \\
(\mathbf{w t} \%)\end{array}$ & $\begin{array}{c}\text { Diff of } \\
\text { Measured }\end{array}$ & $\begin{array}{c}\text { Diff of } \\
\text { Meas BC } \\
\end{array}$ & $\begin{array}{l}\% \text { Diff of } \\
\text { Measured }\end{array}$ & $\begin{array}{l}\text { \% Diff of } \\
\text { Meas BC }\end{array}$ \\
\hline 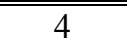 & VIS-4 & $\mathrm{SiO} 2(\mathrm{wt} \%)$ & 48.2947 & 47.1069 & 49.0256 & -0.7309 & -1.9187 & $-1.5 \%$ & $-3.9 \%$ \\
\hline 4 & VIS-4 & ThO2 (wt\%) & 0.0569 & 0.0569 & 0.0129 & 0.0440 & 0.0440 & $341.0 \%$ & $341.0 \%$ \\
\hline 4 & VIS-4 & $\mathrm{TiO} 2(w \mathrm{w} \%)$ & 0.0225 & 0.0235 & 0.0126 & 0.0099 & 0.0109 & $78.7 \%$ & $86.6 \%$ \\
\hline 4 & VIS-4 & $\mathrm{U} 3 \mathrm{O} 8(\mathrm{wt} \%)$ & 3.6437 & 3.7678 & 3.8021 & -0.1584 & -0.0343 & $-4.2 \%$ & $-0.9 \%$ \\
\hline 4 & VIS-4 & $\mathrm{ZnO}(\mathrm{wt} \%)$ & 0.0588 & 0.0588 & 0.0563 & 0.0025 & 0.0025 & $4.5 \%$ & $4.5 \%$ \\
\hline 4 & VIS-4 & $\mathrm{ZrO} 2(\mathrm{wt} \%)$ & 0.0831 & 0.0831 & 0.0985 & -0.0154 & -0.0154 & $-15.7 \%$ & $-15.7 \%$ \\
\hline 4 & VIS-4 & Sum of Oxides & 98.5657 & 98.0077 & 99.9999 & -1.4342 & -1.9922 & $-1.4 \%$ & $-2.0 \%$ \\
\hline 5 & VIS-5 & $\mathrm{A} 12 \mathrm{O} 3$ (wt\%) & 6.5377 & 6.5070 & 6.1242 & 0.4135 & 0.3828 & $6.8 \%$ & $6.3 \%$ \\
\hline 5 & VIS-5 & $\mathrm{B} 2 \mathrm{O} 3(\mathrm{wt} \%)$ & 4.5803 & 4.6907 & 4.8000 & -0.2197 & -0.1093 & $-4.6 \%$ & $-2.3 \%$ \\
\hline 5 & VIS-5 & $\mathrm{BaO}(\mathrm{wt} \%)$ & 0.0555 & 0.0585 & 0.0592 & -0.0037 & -0.0007 & $-6.2 \%$ & $-1.1 \%$ \\
\hline 5 & VIS-5 & $\mathrm{CaO}(\mathrm{wt} \%)$ & 1.1299 & 1.1429 & 1.1637 & -0.0338 & -0.0208 & $-2.9 \%$ & $-1.8 \%$ \\
\hline 5 & VIS-5 & $\mathrm{Ce} 2 \mathrm{O} 3(\mathrm{wt} \%)$ & 0.0603 & 0.0603 & 0.0955 & -0.0352 & -0.0352 & $-36.8 \%$ & $-36.8 \%$ \\
\hline 5 & VIS-5 & $\mathrm{Cr} 2 \mathrm{O} 3(\mathrm{wt} \%)$ & 0.1093 & 0.1048 & 0.0953 & 0.0140 & 0.0095 & $14.6 \%$ & $10.0 \%$ \\
\hline 5 & VIS-5 & $\mathrm{CuO}(\mathrm{wt} \%)$ & 0.0526 & 0.0553 & 0.0357 & 0.0169 & 0.0196 & $47.3 \%$ & $55.0 \%$ \\
\hline 5 & VIS-5 & $\mathrm{Fe} 2 \mathrm{O} 3(\mathrm{wt} \%)$ & 12.1560 & 12.4166 & 13.0798 & -0.9238 & -0.6632 & $-7.1 \%$ & $-5.1 \%$ \\
\hline 5 & VIS-5 & $\mathrm{K} 2 \mathrm{O}(\mathrm{wt} \%)$ & 0.1093 & 0.1171 & 0.0835 & 0.0258 & 0.0336 & $30.9 \%$ & $40.3 \%$ \\
\hline 5 & VIS-5 & La2O3 (wt\%) & 0.0422 & 0.0422 & 0.0466 & -0.0044 & -0.0044 & $-9.4 \%$ & $-9.4 \%$ \\
\hline 5 & VIS-5 & $\mathrm{Li} 2 \mathrm{O}(\mathrm{wt} \%)$ & 4.8010 & 4.9178 & 4.8000 & 0.0010 & 0.1178 & $0.0 \%$ & $2.5 \%$ \\
\hline 5 & VIS-5 & $\mathrm{MgO}(\mathrm{wt} \%)$ & 1.3062 & 1.3657 & 1.4263 & -0.1201 & -0.0606 & $-8.4 \%$ & $-4.2 \%$ \\
\hline 5 & VIS-5 & $\mathrm{MnO}(\mathrm{wt} \%)$ & 2.8213 & 2.8427 & 2.6742 & 0.1471 & 0.1685 & $5.5 \%$ & $6.3 \%$ \\
\hline 5 & VIS-5 & $\mathrm{Na} 2 \mathrm{O}(\mathrm{wt} \%)$ & 14.0866 & 13.8629 & 13.6069 & 0.4797 & 0.2560 & $3.5 \%$ & $1.9 \%$ \\
\hline 5 & VIS-5 & $\mathrm{NiO}(\mathrm{wt} \%)$ & 0.6067 & 0.6500 & 0.7056 & -0.0989 & -0.0556 & $-14.0 \%$ & $-7.9 \%$ \\
\hline 5 & VIS-5 & $\mathrm{PbO}(\mathrm{wt} \%)$ & 0.0563 & 0.0563 & 0.0571 & -0.0008 & -0.0008 & $-1.4 \%$ & $-1.4 \%$ \\
\hline 5 & VIS-5 & $\mathrm{SiO} 2(\mathrm{wt} \%)$ & 46.8507 & 45.9540 & 46.8385 & 0.0122 & -0.8845 & $0.0 \%$ & $-1.9 \%$ \\
\hline 5 & VIS-5 & $\mathrm{ThO} 2(\mathrm{wt} \%)$ & 0.0569 & 0.0569 & 0.0139 & 0.0430 & 0.0430 & $309.3 \%$ & $309.3 \%$ \\
\hline 5 & VIS-5 & $\mathrm{TiO} 2(w t \%)$ & 0.0209 & 0.0216 & 0.0136 & 0.0073 & 0.0080 & $53.3 \%$ & $59.0 \%$ \\
\hline 5 & VIS-5 & U3O8 (wt\%) & 3.9533 & 4.0841 & 4.1104 & -0.1571 & -0.0263 & $-3.8 \%$ & $-0.6 \%$ \\
\hline 5 & VIS-5 & $\mathrm{ZnO}(\mathrm{wt} \%)$ & 0.0747 & 0.0747 & 0.0609 & 0.0138 & 0.0138 & $22.6 \%$ & $22.6 \%$ \\
\hline 5 & VIS-5 & $\mathrm{ZrO} 2(\mathrm{wt} \%)$ & 0.0915 & 0.0915 & 0.1065 & -0.0150 & -0.0150 & $-14.1 \%$ & $-14.1 \%$ \\
\hline 5 & VIS-5 & Sum of Oxides & 99.5589 & 99.1737 & 99.9974 & -0.4385 & -0.8237 & $-0.4 \%$ & $-0.8 \%$ \\
\hline 6 & VIS-6 & $\mathrm{Al} 2 \mathrm{O} 3(\mathrm{wt} \%)$ & 7.1518 & 7.1180 & 6.8897 & 0.2621 & 0.2283 & $3.8 \%$ & $3.3 \%$ \\
\hline 6 & VIS-6 & $\mathrm{B} 2 \mathrm{O} 3(\mathrm{wt} \%)$ & 4.4918 & 4.3791 & 4.4000 & 0.0918 & -0.0209 & $2.1 \%$ & $-0.5 \%$ \\
\hline 6 & VIS-6 & $\mathrm{BaO}(\mathrm{wt} \%)$ & 0.0558 & 0.0588 & 0.0592 & -0.0034 & -0.0004 & $-5.7 \%$ & $-0.6 \%$ \\
\hline 6 & VIS-6 & $\mathrm{CaO}(\mathrm{wt} \%)$ & 1.2813 & 1.2961 & 1.3092 & -0.0279 & -0.0131 & $-2.1 \%$ & $-1.0 \%$ \\
\hline 6 & VIS-6 & $\mathrm{Ce} 2 \mathrm{O} 3(\mathrm{wt} \%)$ & 0.0779 & 0.0779 & 0.1074 & -0.0295 & -0.0295 & $-27.5 \%$ & $-27.5 \%$ \\
\hline 6 & VIS-6 & $\mathrm{Cr} 2 \mathrm{O} 3(\mathrm{wt} \%)$ & 0.0720 & 0.0690 & 0.1073 & -0.0353 & -0.0383 & $-32.9 \%$ & $-35.7 \%$ \\
\hline 6 & VIS-6 & $\mathrm{CuO}(\mathrm{wt} \%)$ & 0.0538 & 0.0567 & 0.0402 & 0.0136 & 0.0165 & $33.9 \%$ & $40.9 \%$ \\
\hline 6 & VIS-6 & $\mathrm{Fe} 2 \mathrm{O} 3(\mathrm{wt} \%)$ & 13.1068 & 13.3875 & 14.7147 & -1.6079 & -1.3272 & $-10.9 \%$ & $-9.0 \%$ \\
\hline 6 & VIS-6 & $\mathrm{K} 2 \mathrm{O}(\mathrm{wt} \%)$ & 0.1174 & 0.1258 & 0.0940 & 0.0234 & 0.0318 & $24.9 \%$ & $33.9 \%$ \\
\hline 6 & VIS-6 & $\mathrm{La} 2 \mathrm{O} 3(\mathrm{wt} \%)$ & 0.0437 & 0.0437 & 0.0524 & -0.0087 & -0.0087 & $-16.6 \%$ & $-16.6 \%$ \\
\hline 6 & VIS-6 & $\mathrm{Li} 2 \mathrm{O}(\mathrm{wt} \%)$ & 4.4457 & 4.5239 & 4.4000 & 0.0457 & 0.1239 & $1.0 \%$ & $2.8 \%$ \\
\hline 6 & VIS-6 & $\mathrm{MgO}(\mathrm{wt} \%)$ & 1.4351 & 1.5005 & 1.6046 & -0.1695 & -0.1041 & $-10.6 \%$ & $-6.5 \%$ \\
\hline 6 & VIS-6 & $\mathrm{MnO}(\mathrm{wt} \%)$ & 3.0601 & 3.0833 & 3.0084 & 0.0517 & 0.0749 & $1.7 \%$ & $2.5 \%$ \\
\hline 6 & VIS-6 & $\mathrm{Na} 2 \mathrm{O}(\mathrm{wt} \%)$ & 14.3225 & 14.0944 & 14.3108 & 0.0117 & -0.2164 & $0.1 \%$ & $-1.5 \%$ \\
\hline
\end{tabular}


Table D4. Average Measured and Bias-Corrected Chemical Compositions Versus Targeted Compositions by Oxide by VIS Glass Number

(100-Batch 1 and 101-Ustd)

\begin{tabular}{|c|c|c|c|c|c|c|c|c|c|}
\hline Glass \# & Glass ID & Oxide & $\begin{array}{c}\text { Measured } \\
(\mathbf{w t} \%) \\
\end{array}$ & $\begin{array}{c}\text { Measured } \\
\text { Bias-Corrected } \\
(\mathbf{w t} \%) \\
\end{array}$ & $\begin{array}{c}\text { Targeted } \\
(\mathbf{w t} \%) \\
\end{array}$ & $\begin{array}{c}\text { Diff of } \\
\text { Measured } \\
\end{array}$ & $\begin{array}{c}\text { Diff of } \\
\text { Meas BC } \\
\end{array}$ & $\begin{array}{r}\% \text { Diff of } \\
\text { Measured } \\
\end{array}$ & $\begin{array}{l}\% \text { Diff of } \\
\text { Meas BC }\end{array}$ \\
\hline 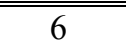 & VIS-6 & $\mathrm{NiO}(\mathrm{wt} \%)$ & 0.6474 & 0.6936 & 0.7937 & "-0.1463 & -0.1001 & $-18.4 \%$ & $-12.6 \%$ \\
\hline 6 & VIS-6 & $\mathrm{PbO}(\mathrm{wt} \%)$ & 0.0641 & 0.0641 & 0.0642 & -0.0001 & -0.0001 & $-0.2 \%$ & $-0.2 \%$ \\
\hline 6 & VIS-6 & $\mathrm{SiO} 2(w t \%)$ & 43.1069 & 42.2817 & 43.2000 & -0.0931 & -0.9183 & $-0.2 \%$ & $-2.1 \%$ \\
\hline 6 & VIS-6 & ThO2 (wt\%) & 0.0569 & 0.0569 & 0.0157 & 0.0412 & 0.0412 & $262.4 \%$ & $262.4 \%$ \\
\hline 6 & VIS-6 & $\mathrm{TiO} 2(\mathrm{wt} \%)$ & 0.0229 & 0.0238 & 0.0153 & 0.0076 & 0.0085 & $49.9 \%$ & $55.4 \%$ \\
\hline 6 & VIS-6 & U3O8 (wt\%) & 4.3159 & 4.4587 & 4.6242 & -0.3083 & -0.1655 & $-6.7 \%$ & $-3.6 \%$ \\
\hline 6 & VIS-6 & $\mathrm{ZnO}(\mathrm{wt} \%)$ & 0.0899 & 0.0899 & 0.0685 & 0.0214 & 0.0214 & $31.3 \%$ & $31.3 \%$ \\
\hline 6 & VIS-6 & $\mathrm{ZrO} 2(\mathrm{wt} \%)$ & 0.0942 & 0.0942 & 0.1198 & -0.0256 & -0.0256 & $-21.4 \%$ & $-21.4 \%$ \\
\hline 6 & VIS-6 & Sum of Oxides & 98.1140 & 97.5775 & 99.9993 & -1.8853 & -2.4218 & $-1.9 \%$ & $-2.4 \%$ \\
\hline
\end{tabular}


Exhibit D1. Oxide Measurements in Analytical Sequence for Samples Prepared Using the LM Method
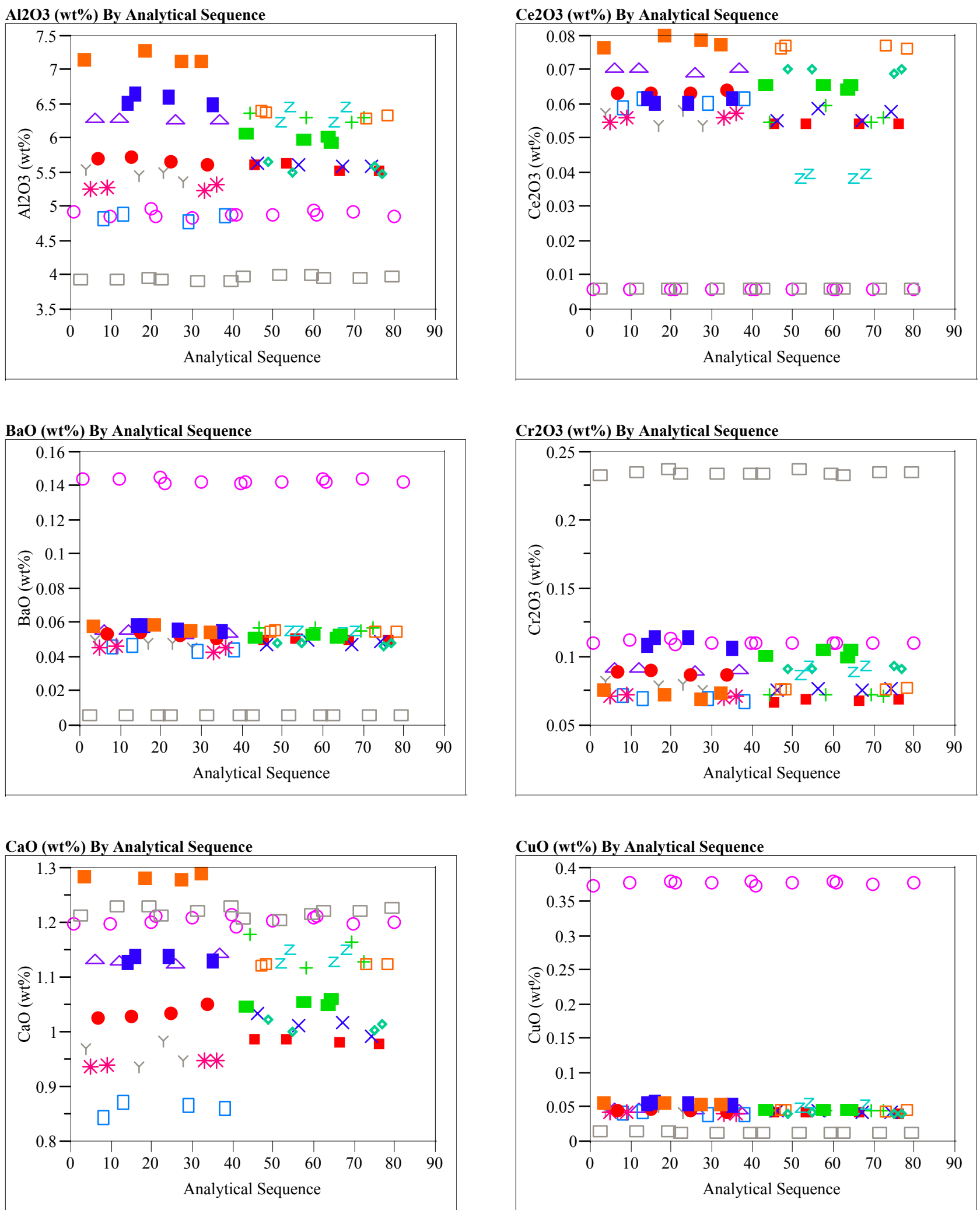
Exhibit D1. Oxide Measurements in Analytical Sequence for Samples Prepared Using the LM Method

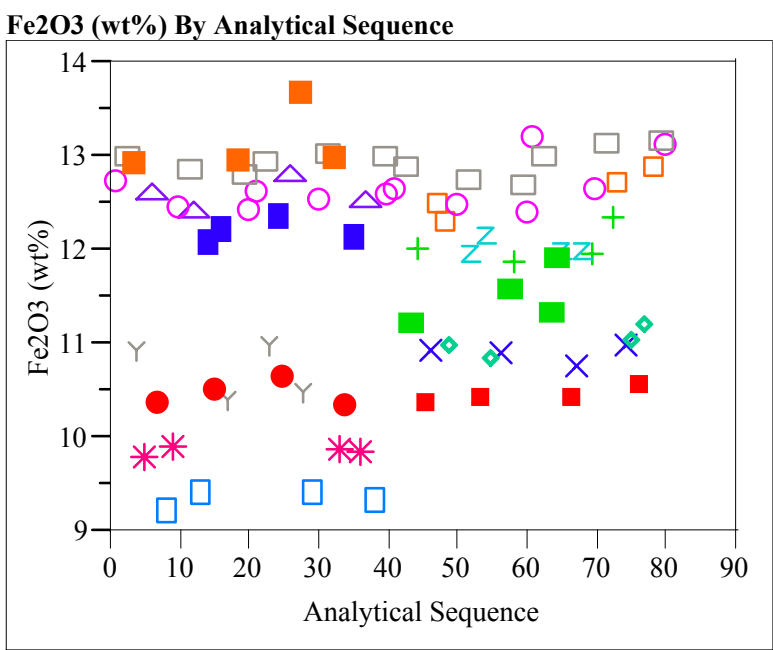

K2O (wt\%) By Analytical Sequence

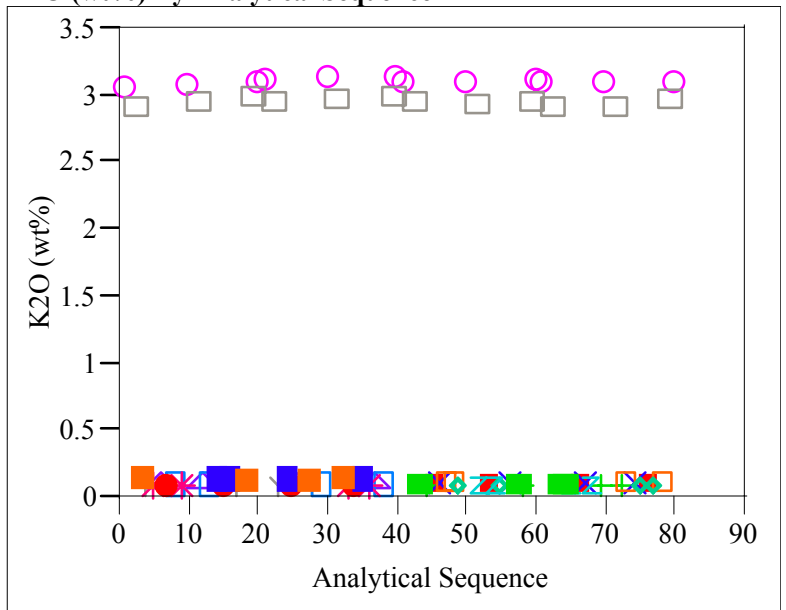

La2O3 (wt\%) By Analytical Sequence

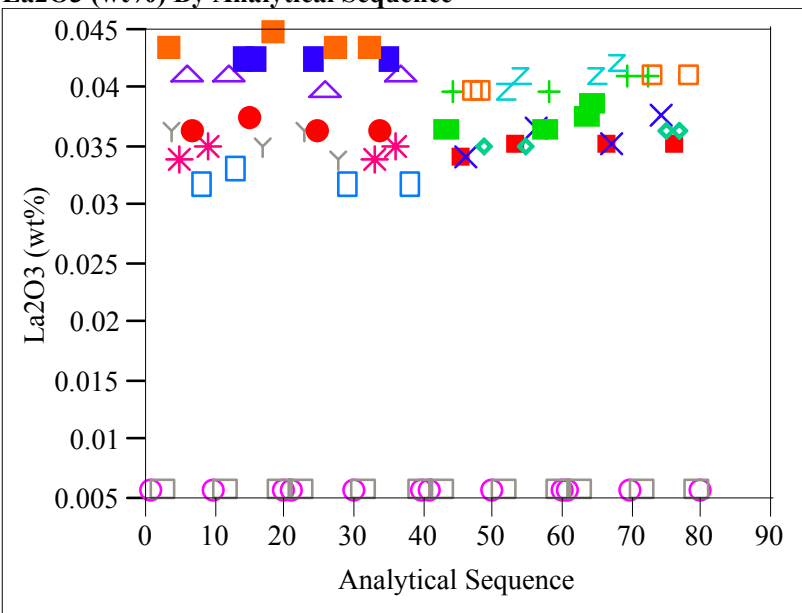

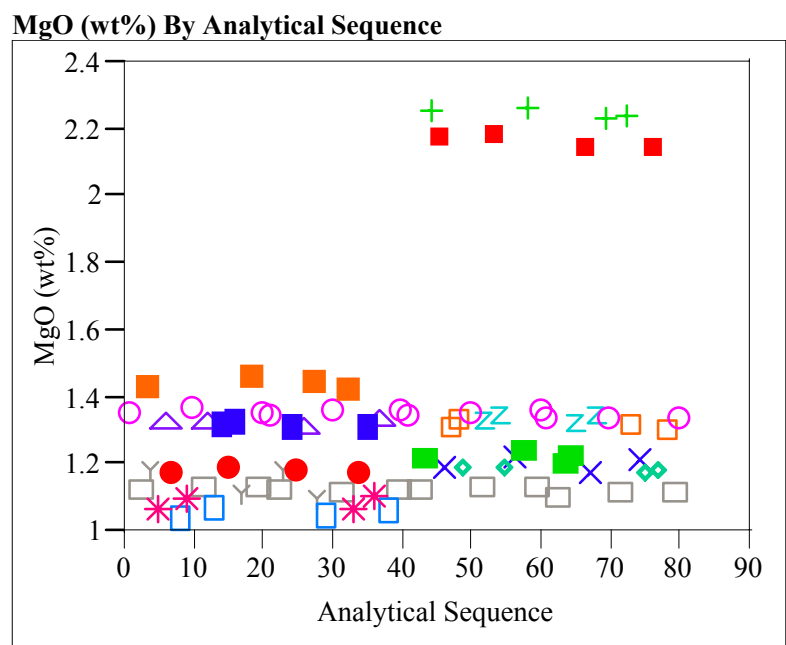

MnO (wt\%) By Analytical Sequence
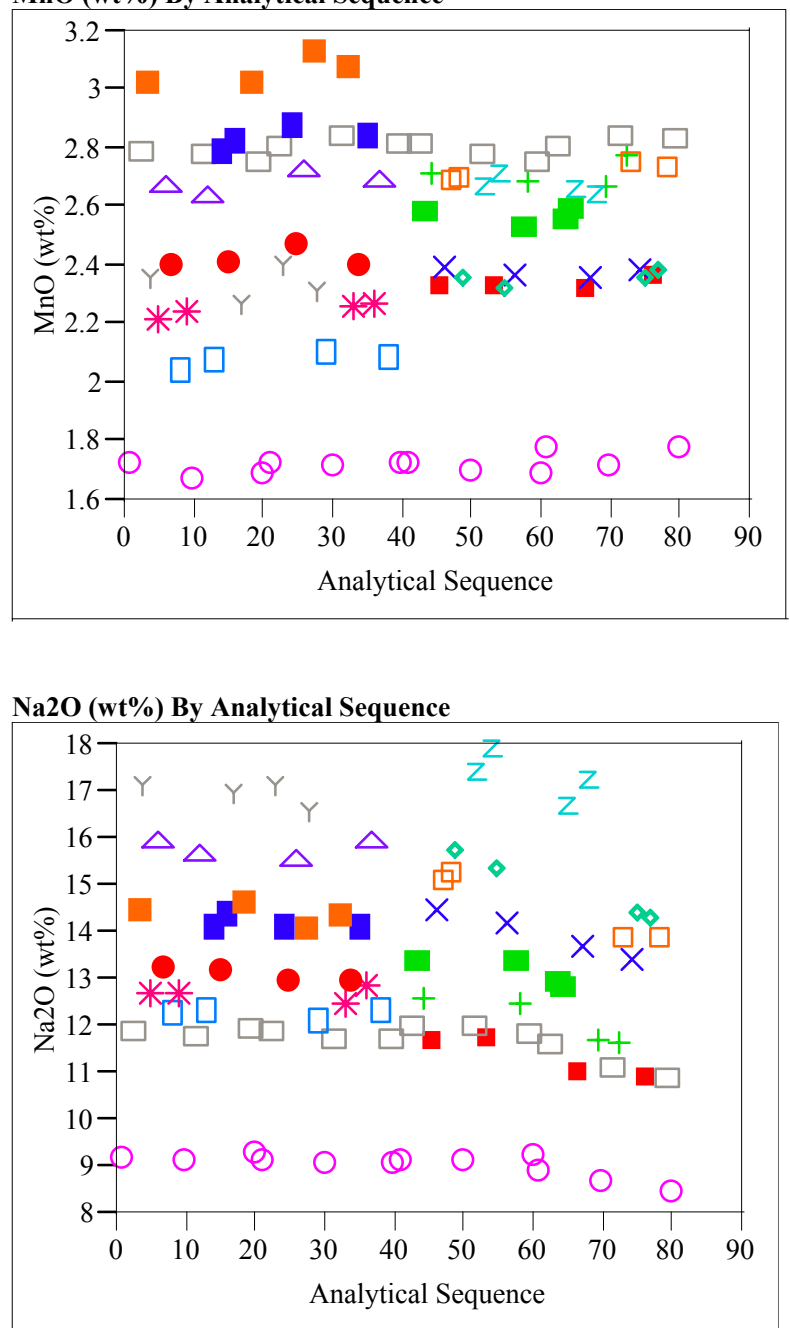
Exhibit D1. Oxide Measurements in Analytical Sequence for Samples Prepared Using the LM Method
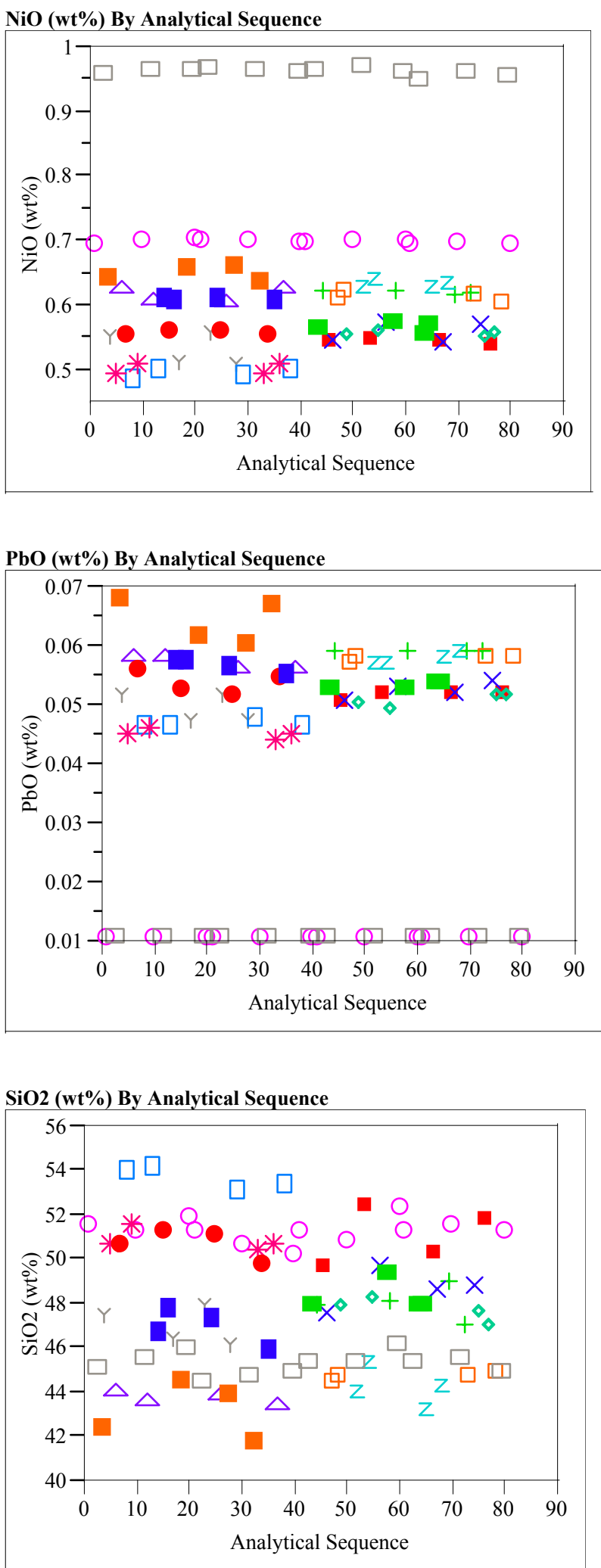

ThO2 (wt\%) By Analytical Sequence

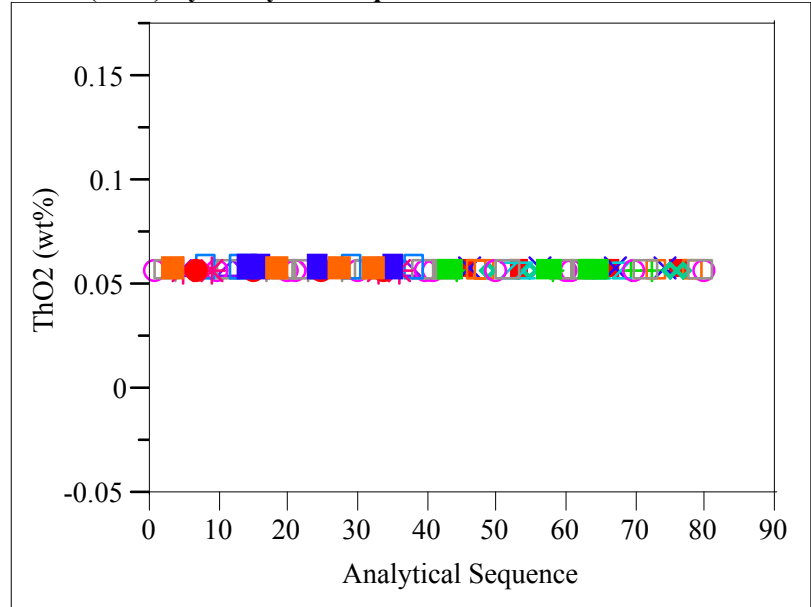

TiO2 (wt \%) By Analytical Sequence

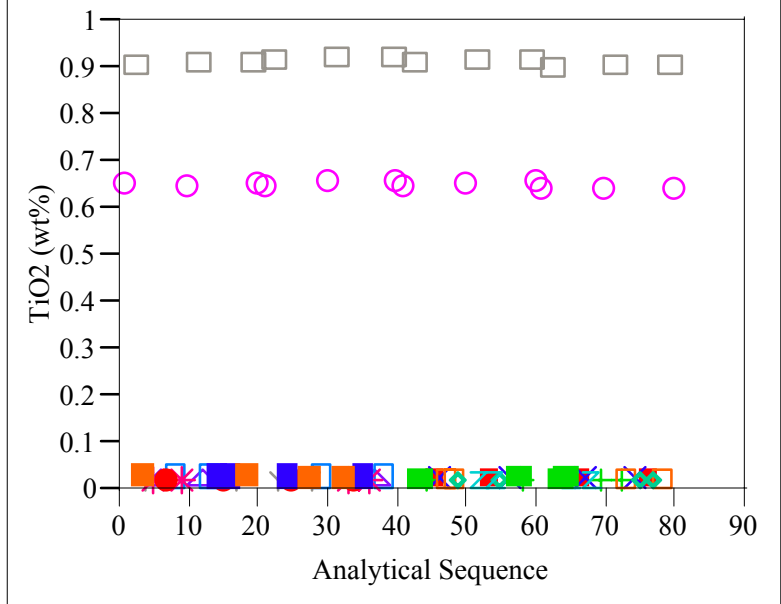

U3O8 (wt\%) By Analytical Sequence

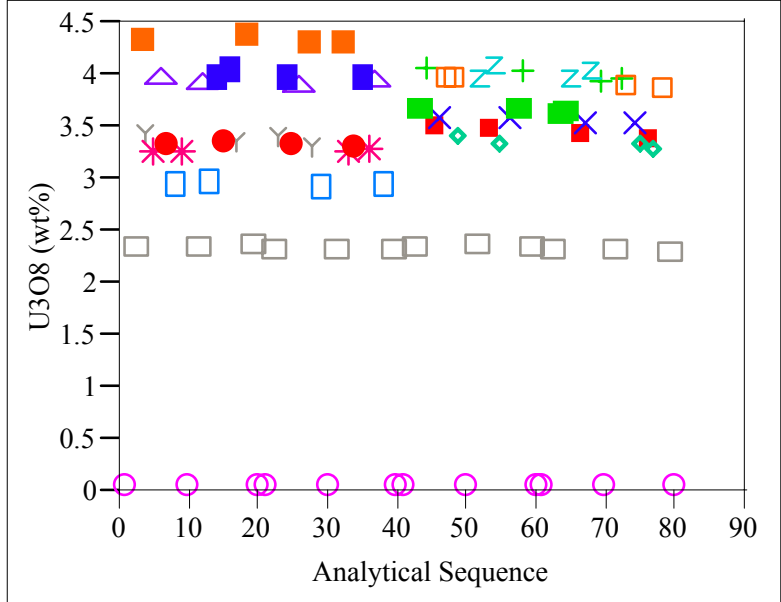


Exhibit D1. Oxide Measurements in Analytical Sequence for Samples Prepared Using the LM Method

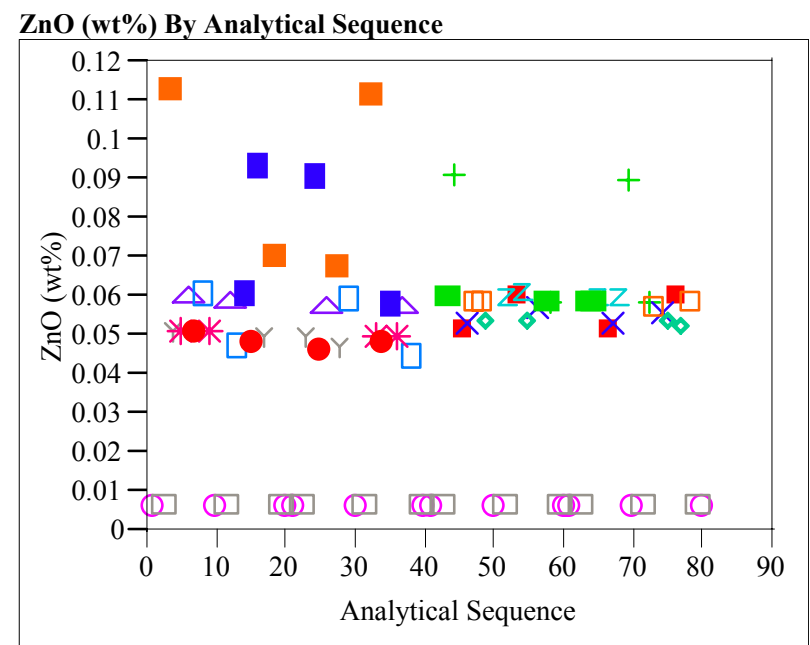

ZrO2 (wt\%) By Analytical Sequence

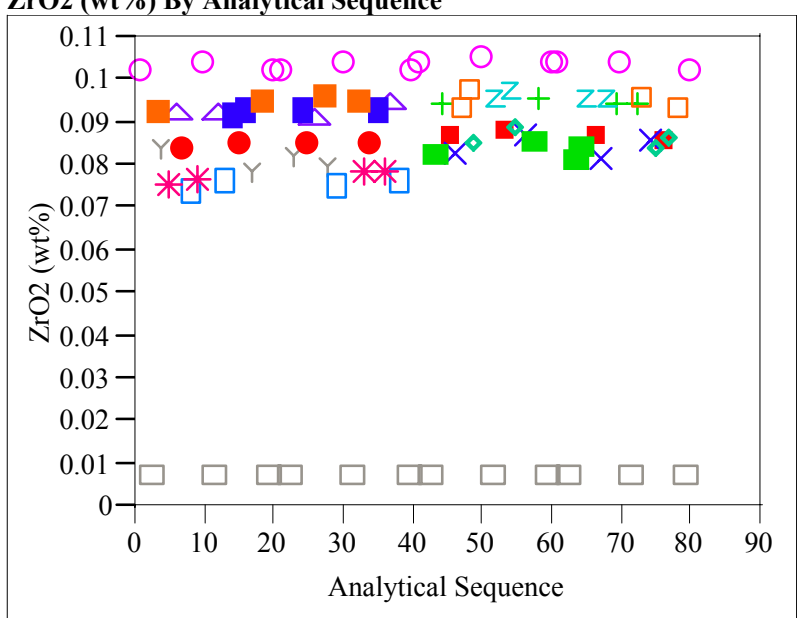


Exhibit D2. Oxide Measurements in Analytical Sequence for Samples Prepared Using the PF Method
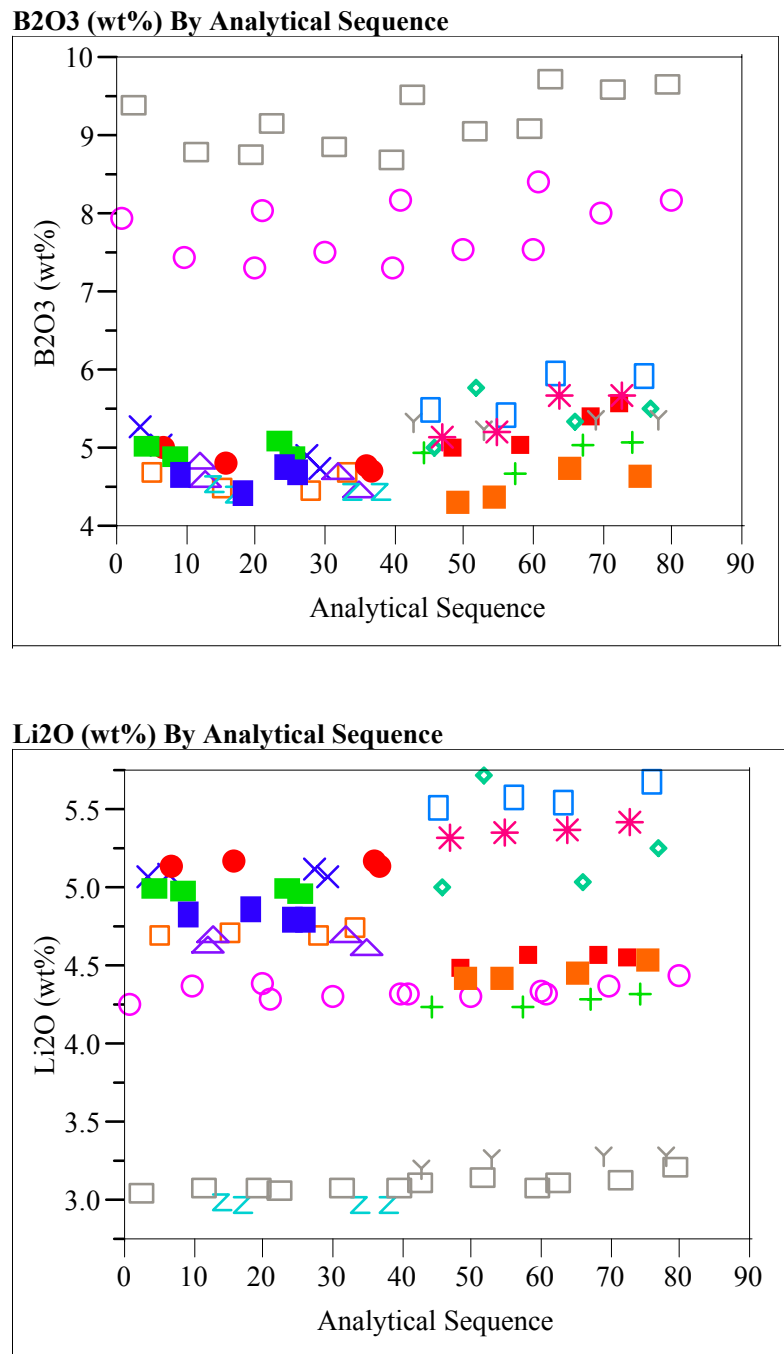


\section{Exhibit D3. SRNL-ML Measurements by Analytical Block for Samples of the Standard Glasses Prepared Using the LM Method}

Glass ID=Batch 1; reference value for $\mathrm{Al} 2 \mathrm{O3}$ is $4.877 \mathrm{wt} \%$ Oneway Analysis of Al2O3 (wt\%) By Block/Sub-Blk

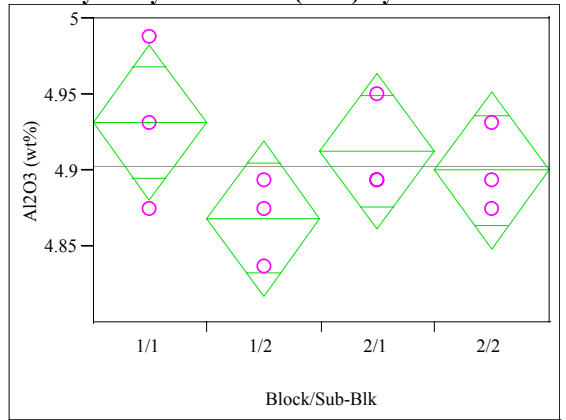

Oneway Anova

Summary of Fi

Rsquare

Root Mean Square Erro

0.346405

Mean of Response

0.038569

4.903252

Observations (or Sum Wgts)

Analysis of Variance

Source

Block/Sub-Blk

Error

C. Total

Means for Oneway Anova

Level Number

Std Error

$\begin{array}{lll}3 & 4.93160 & 0.02227\end{array}$

$\begin{array}{llll}1 / 2 & 3 & 4.86861 & 0.02227\end{array}$

$\begin{array}{llll}2 / 1 & 3 & 4.91270 & 0.02227\end{array}$

$\begin{array}{llll}2 / 2 & 3 & 4.90010 & 0.02227\end{array}$

Std Error uses a pooled estimate of error variance

Glass ID=Batch 1; reference value for $\mathrm{BaO}$ is $0.151 \mathrm{wt} \%$

Oneway Analysis of $\mathrm{BaO}(\mathrm{wt} \%)$ By Block/Sub-Blk

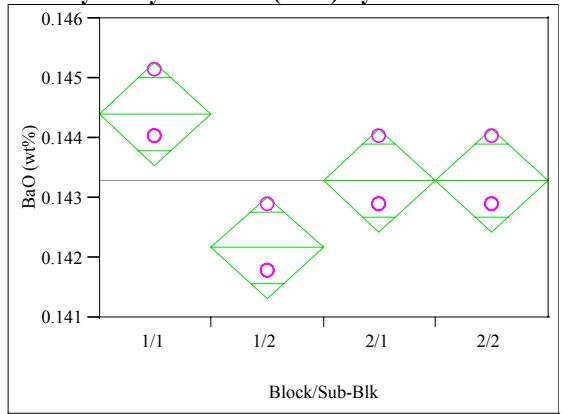

Oneway Anova

Summary of Fit

Rsquare

0.692308

Root Mean Square Error

0.000645

Mean of Response

0.143284

Observations (or Sum Wgts)

12

Analysis of Variance

Source

Block/Sub-Blk

Error

C. Total

$\begin{array}{rr}\text { DF } & \text { Sum of Squares } \\ 3 & 0.00000748 \\ 8 & 0.00000332\end{array}$

0.00000332

Mean Square

0.0000025

$4.1552 \mathrm{e}-7$

Means for Oneway Anova

Level Number Mean Std Error

$\begin{array}{llll}1 / 1 & 3 & 0.144401 & 0.00037\end{array}$

$\begin{array}{llll}1 / 2 & 3 & 0.142168 & 0.00037\end{array}$

$\begin{array}{llll}2 / 1 & 3 & 0.143284 & 0.00037\end{array}$

$2 / 2$

$\begin{array}{lll}3 & 0.143284 & 0.00037\end{array}$

Std Error uses a pooled estimate of error variance

ean Square 0.002102

0.14354

0.14243
Glass ID=Batch 1; reference value for $\mathrm{CaO}$ is $1.220 \mathrm{wt} \%$ Oneway Analysis of $\mathrm{CaO}$ (wt\%) By Block/Sub-Blk

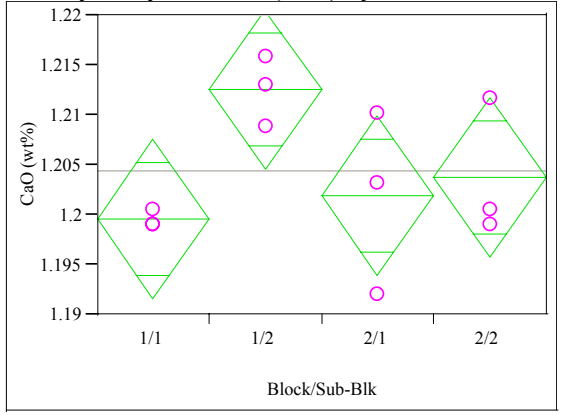

\section{Oneway Anova}

Summary of Fit

Rsquare

0.5028

Root Mean Square Error

0.006018

Mean of Response

1.204478

Observations (or Sum Wgts)

Analysis of Variance

Source

F Ratio Prob $>$ F

$1.4133 \quad 0.3084$ $\begin{array}{lrr}\text { Error } & 8 & 0.00028975 \\ \text { C. Total } & 11 & 0.00058276\end{array}$

DF Sum of Squares 0.00029301
0.00028975

Mean Square 0.000098 0.000036

Ratio 2.6967

Prob $>$ F

Means for Oneway Anova

Level Number Mean Std Error Lower 95\% Upper 95\%

$\begin{array}{llllll}1 / 1 & 3 & 1.19958 & 0.00347 & 1.1916 & 1.2076\end{array}$

$\begin{array}{llllll}1 / 2 & 3 & 1.21264 & 0.00347 & 1.2046 & 1.2207\end{array}$

$\begin{array}{llllll}2 / 1 & 3 & 1.20191 & 0.00347 & 1.1939 & 1.2099\end{array}$

$\begin{array}{llllll}2 / 2 & 3 & 1.20378 & 0.00347 & 1.1958 & 1.2118\end{array}$

Std Error uses a pooled estimate of error variance

Glass ID=Batch 1; reference value for $\mathrm{Ce} 2 \mathrm{O3}$ is $0 \mathrm{wt} \%$ Oneway Analysis of Ce2O3 (wt\%) By Block/Sub-Blk

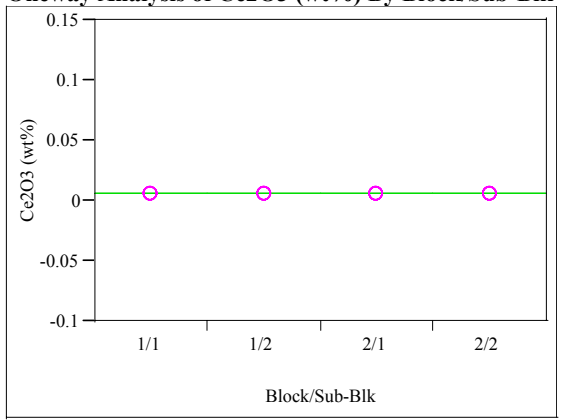

\section{Oneway Anova}

Summary of Fit

Rsquare

Root Mean Square Error $\quad 0$

$\begin{array}{lr}\text { Mean of Response } & 0.005857 \\ \text { Observations (or Sum Wgts) } & 12\end{array}$

Analysis of Variance

F Ratio Prob $>$ F

Source

Block/Sub-Blk

Error

C. Total

DF
3

Sum of Squares

12

Lower 95\% Upper 95\%

$0.14131 \quad 0.14303$

$0.14243 \quad 0.14414$
Means for Oneway Anova

$\begin{array}{lrrrr}\text { Level } & \text { Number } & \text { Mean } & \text { Std Error } & \text { Lower 95\% } \\ 1 / 1 & 3 & 0.005857 & 0 & 0.00586 \\ 1 / 2 & 3 & 0.005857 & 0 & 0.00586 \\ 2 / 1 & 3 & 0.005857 & 0 & 0.00586 \\ 2 / 2 & 3 & 0.005857 & 0 & 0.00586\end{array}$

Std Error uses a pooled estimate of error variance
Mean Square

F Ratio Prob $>$ F 


\section{Exhibit D3. SRNL-ML Measurements by Analytical Block for Samples of the Standard Glasses Prepared Using the LM Method}

Glass ID=Batch 1; reference value for $\mathrm{Cr} 203$ is $0.107 \mathrm{wt} \%$ Oneway Analysis of Cr2O3 (wt\%) By Block/Sub-Blk

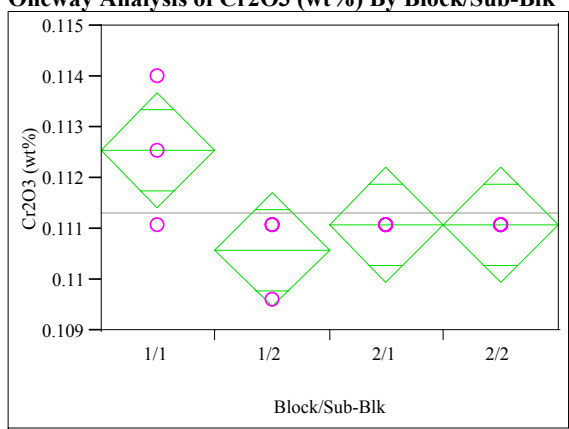

Oneway Anova

Summary of Fit

Root Mean Square Error

0.529412

Mean of Response

0.000844

12

Observations (or Sum Wgts)

Analysis of Variance

Source

Block/Sub-Blk

Error

C. Total

Means for Oneway Anova

Level Number Mean Std Error

$\begin{array}{lrrrr}1 / 1 & 3 & 0.112543 & 0.00049 & 0.11142 \\ 1 / 2 & 3 & 0.110594 & 0.00049 & 0.10947 \\ 2 / 1 & 3 & 0.111082 & 0.00049 & 0.10996 \\ 2 / 2 & 3 & 0.111082 & 0.00049 & 0.10996\end{array}$

Std Error uses a pooled estimate of error variance

Glass ID=Batch 1; reference value for $\mathrm{CuO}$ is $0.399 \mathrm{wt} \%$

Oneway Analysis of $\mathrm{CuO}$ (wt\%) By Block/Sub-BIk

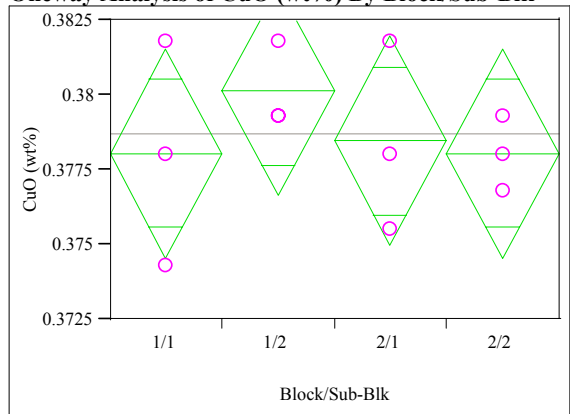

Oneway Anova

Summary of Fit

Rsquare

Root Mean Square Erro

0.138211

Mean of Response

0.002631

Observations (or Sum Wgts)

0.378669

Analysis of Variance

Source

Block/Sub-Blk

Error

C. Total

$\begin{array}{rr}\text { DF } & \text { Sum of Squares } \\ 3 & 0.00000888\end{array}$ 0.00000888

0.00006425

Means for Oneway Anova

Level Number Mean Std Error

$\begin{array}{llll}1 / 1 & 3 & 0.378044 & 0.00152\end{array}$

$\begin{array}{llll}1 / 2 & 3 & 0.380130 & 0.00152\end{array}$

$\begin{array}{llll}2 / 1 & 3 & 0.378461 & 0.00152\end{array}$

$\begin{array}{llll}2 / 2 & 3 & 0.378044 & 0.00152\end{array}$

Std Error uses a pooled estimate of error variance
Glass ID=Batch 1; reference value for $\mathrm{Fe} 2 \mathrm{O3}$ is $12.839 \mathrm{wt} \%$ Oneway Analysis of Fe2O3 (wt\%) By Block/Sub-Blk

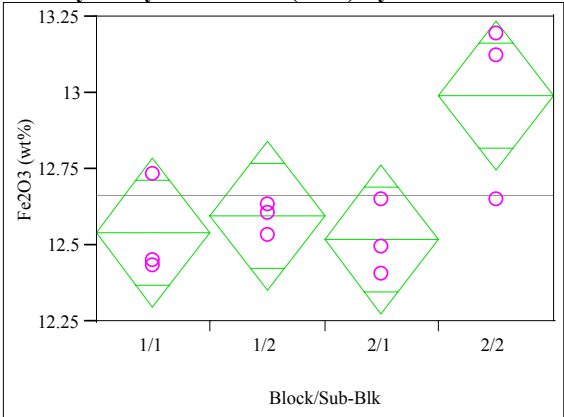

Oneway Anova

Summary of Fit

Rsquare

Root Mean Square Error 0.62291

Mean of Respons

0.182812

Observations (or Sum Wgts)

Analysis of Variance

Source

F Ratio Prob $>$ F

$0.0000021 \quad 3.0000 \quad 0.0951$

Block/

Blk $\quad$ DF

Sum of Squares 0.44164936 0.26736071

Mean Square 0.147216

F Ratio 4.4050

Prob $>$ F

$\begin{array}{lll}\text { C. Total } & 11 & 0.70901007\end{array}$

Means for Oneway Anova

Level Number Mean Std Error Lower 95\% Upper 95\%

Upper $95 \%$

0.11367

0.11172

0.11221

$\begin{array}{lrrrrr}\text { Level } & \text { Number } & \text { Mean } & \text { Std Error } & \text { Lower 95\% } & \text { Upper 95\% } \\ 1 / 1 & 3 & 12.5432 & 0.10555 & 12.300 & 12.787 \\ 1 / 2 & 3 & 12.5957 & 0.10555 & 12.352 & 12.839 \\ 2 / 1 & 3 & 12.5194 & 0.10555 & 12.276 & 12.763 \\ 2 / 2 & 3 & 12.9912 & 0.10555 & 12.748 & 13.235\end{array}$

Std Error uses a pooled estimate of error variance

Glass ID=Batch 1; reference value for $\mathrm{K2O}$ is $3.327 \mathrm{wt} \%$ Oneway Analysis of $\mathrm{K} 2 \mathrm{O}$ (wt \%) By Block/Sub-BIk

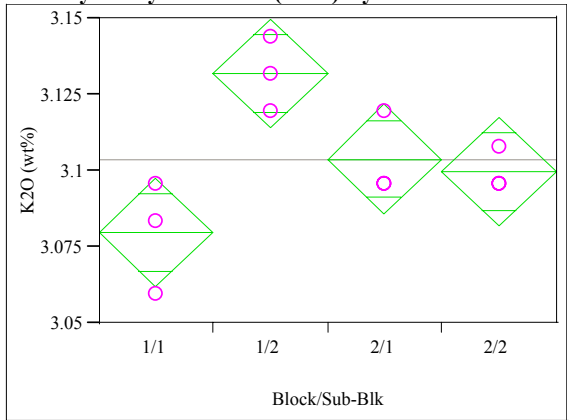

\section{Oneway Anova}

Summary of Fit

Rsquare $\quad 0.741379$

Root Mean Square Error $\quad 0.013468$

Mean of Response 3.103853

Observations (or Sum Wgts) 12

Analysis of Variance

Mean Square F Ratio Prob $>$ F

$\begin{array}{lll}0.000003 & 0.4277 & 0.7387\end{array}$

Source

Block/Sub-Blk DF Sum of Squares

$3-0.00415971$

$\begin{array}{lll}\text { Error } & 8 & 0.00145106\end{array}$

$\begin{array}{lll}\text { C. Total } & 11 & 0.00561077\end{array}$

Means for Oneway Anova

Lower 95\% Upper 95\%

$0.37454-0.38155$

$0.37663 \quad 0.38363$

$0.37496 \quad 0.38196$

0.37454
Level Number Mean Std Error $\quad$ Lower 95\% Upper 95\%

$\begin{array}{rrrrrr}1 / 1 & 3 & 3.07976 & 0.00778 & 3.0618 & 3.0977\end{array}$

$\begin{array}{llllll}1 / 1 & 3 & 3.07976 & 0.00778 & 3.0618 & 3.0977 \\ 2 / 1 & 3 & 3.13196 & 0.00778 & 3.1140 & 3.1499\end{array}$

$\begin{array}{llllll}2 / 1 & 3 & 3.10385 & 0.00778 & 3.0859 & 3.1218\end{array}$

$\begin{array}{llllll}2 / 2 & 3 & 3.09984 & 0.00778 & 3.0819 & 3.1178\end{array}$

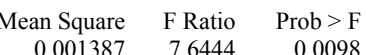

7.6444 


\section{Exhibit D3. SRNL-ML Measurements by Analytical Block for Samples of the Standard Glasses Prepared Using the LM Method}

Glass ID=Batch 1; reference value for $\mathrm{La2O3}$ is $0 \mathrm{wt} \%$ Oneway Analysis of La2O3 (wt\%) By Block/Sub-Blk

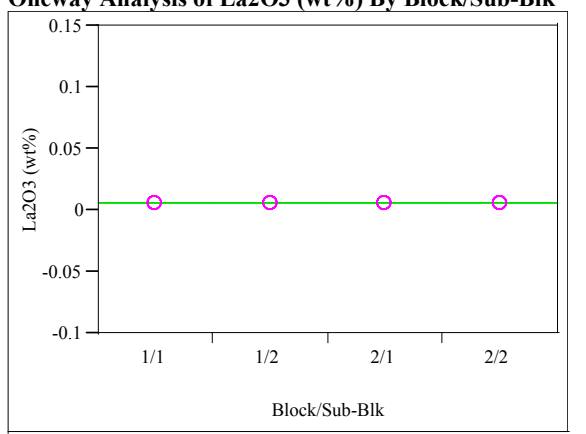

\section{Oneway Anova}

Summary of Fit

Rsquare

Root Mean Square Error

Mean of Response

Observations (or Sum Wgts)

Analysis of Variance

Source

Block/Sub-Blk

Error

C. Total

Level Number Mean Std Error Lower 95\%

$\begin{array}{lllll}1 / 2 & 3 & 0.005864 & 0 & 0.00586 \\ 2 / 1 & 3 & 0.005864 & 0 & 0.00586\end{array}$

$\begin{array}{lllll}2 / 1 & 3 & 0.005864 & 0 & 0.00586\end{array}$

$\begin{array}{lllll}2 / 2 & 3 & 0.005864 & 0 & 0.00586\end{array}$

Std Error uses a pooled estimate of error variance

Glass ID=Batch 1; reference value for $\mathrm{MgO}$ is $1.419 \mathrm{wt} \%$

Oneway Analysis of $\mathrm{MgO}(\mathrm{wt} \%)$ By Block/Sub-Blk

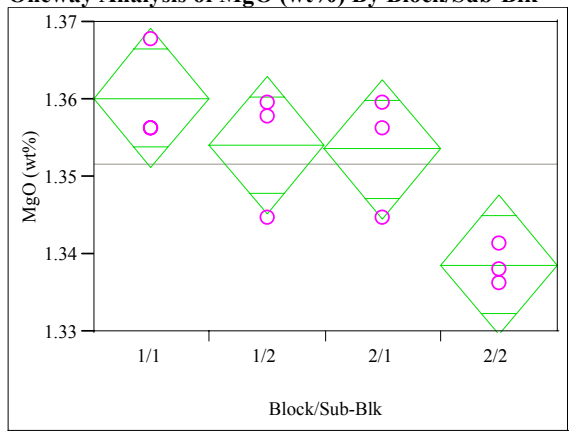

Oneway Anova

Summary of Fit

Rsquare

0.677896

Root Mean Square Error

0.006701

Mean of Response

1.351628

Observations (or Sum Wgts)

12

Analysis of Variance

Source

Block/Sub-Blk

Error

C. Total

DF Sum of Squares

0.00075606

0.00035924

0.00111530

Means for Oneway Anova

Level Number Mean Std Error

$\begin{array}{llll}1 / 1 & 3 & 1.36019 & 0.00387\end{array}$

$\begin{array}{llll}1 / 2 & 3 & 1.35412 & 0.00387\end{array}$

$\begin{array}{llll}2 / 1 & 3 & 1.35356 & 0.00387\end{array}$

$\begin{array}{llll}2 / 2 & 3 & 1.33864 & 0.00387\end{array}$

Std Error uses a pooled estimate of error variance 0.000045
Glass ID=Batch 1; reference value for $\mathrm{MnO}$ is $1.726 \mathrm{wt} \%$ Oneway Analysis of MnO (wt\%) By Block/Sub-Blk

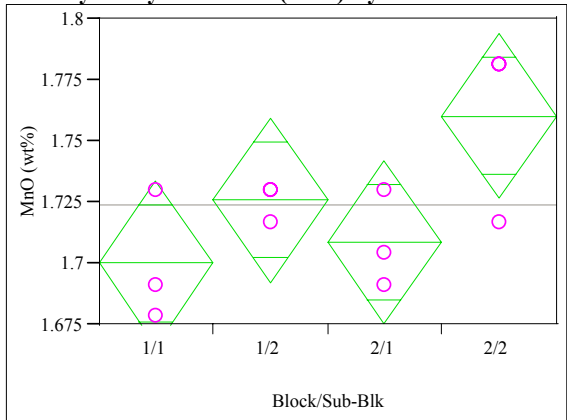

Oneway Anova

Summary of Fit

Rsquare $\quad 0.555556$

Root Mean Square Error

Mean of Response

0.02528
1.723752

Observations (or Sum Wgts)

Analysis of Variance

Block/Sub-Blk $\quad 3$

Error 0.00639092

0.00511274

Mean Square 0.002130

F Ratio 3.3333

Prob $>$ F

C. Total 11

Means for Oneway Anova

Level Number Mean Std Error Lower 95\% Upper 95\%

Upper $95 \%$ 0.00586 0.00586

0.00586

0.00586 0.01460 0.01460 0.01460 $\begin{array}{lccc}2 / 2 & 3 & 1.76034 & 0.01460 \\ \text { Std Error uses a pooled estimate of error variance }\end{array}$

Glass ID=Batch 1; reference value for $\mathrm{Na2O}$ is $9.003 \mathrm{wt} \%$ Oneway Analysis of Na2O (wt\%) By Block/Sub-Blk

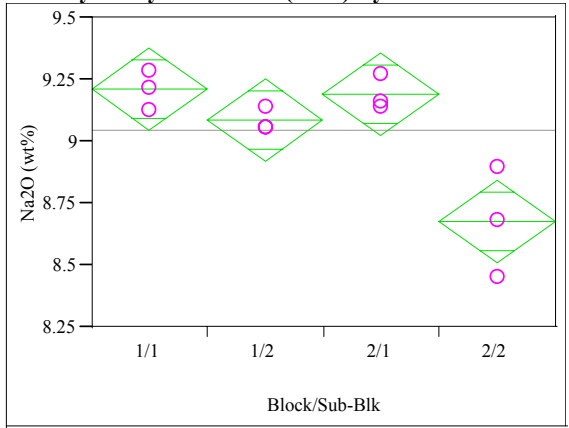

\section{Oneway Anova}

Summary of Fit

Rsquare

0.815727

Root Mean Square Error

0.125853

Mean of Response

9.04171

Observations (or Sum Wgts)

Analysis of Variance

Mean Square F Ratio Prob $>$ F

Source $\begin{array}{lll}0.000252 & 5.6122 & 0.0228\end{array}$

Block/

Error

C. Total

DF

Sum of Squares 0.56092486

0.12671272 0.186975 0.015839

F Ratio 11.8047

Prob $>$ F

Means for Oneway Anova

$\begin{array}{rr}\text { Lower 95\% } & \text { Upper 95\% } \\ 1.3513 & 1.3691 \\ 1.3452 & 1.3630 \\ 1.3446 & 1.3625 \\ 1.3297 & 1.3476\end{array}$

Level Number Mean Std Error

$\begin{array}{lrrr}1 / 1 & 3 & 9.21133 & 0.07266 \\ 1 / 2 & 3 & 9.08552 & 0.07266 \\ 2 / 1 & 3 & 9.19336 & 0.07266\end{array}$

$2 / 2$ 38.67663 0.07266

Lower 95\% 9.0438 8.9180 9.0258 8.5091
Upper 95\% 9.3789

9.2531

9.3609

8.8442 


\section{Exhibit D3. SRNL-ML Measurements by Analytical Block for Samples of the Standard Glasses Prepared Using the LM Method}

Glass $\mathrm{ID}=$ Batch 1 ; reference value for $\mathrm{NiO}$ is $0.751 \mathrm{wt} \%$ Oneway Analysis of $\mathrm{NiO}$ (wt\%) By Block/Sub-Blk

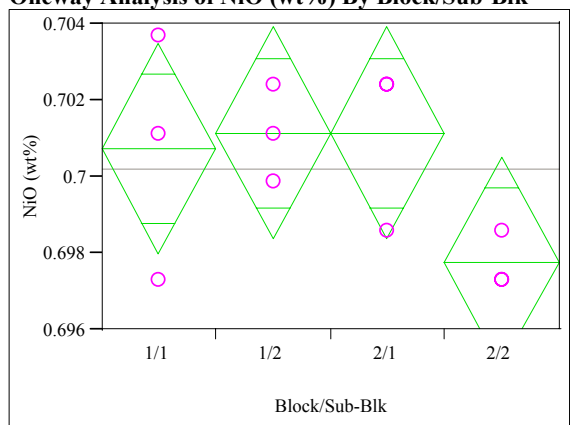

Oneway Anova

Summary of Fit

Rsquare

Root Mean Square Error

0.411494

0.002078

0.700193

Observations (or Sum Wgts)

Analysis of Variance

Source

Block/Sub-Blk

Error

C. Total

Means for Oneway Anova

$\begin{array}{lrrrr}\text { Level } & \text { Number } & \text { Mean } & \text { Std Error } & \text { Lower 95\% } \\ 1 / 1 & 3 & 0.700723 & 0.00120 & 0.69796 \\ 1 / 2 & 3 & 0.701147 & 0.00120 & 0.69838 \\ 2 / 1 & 3 & 0.701147 & 0.00120 & 0.69838 \\ 2 / 2 & 3 & 0.697754 & 0.00120 & 0.69499\end{array}$

Std Error uses a pooled estimate of error variance

Glass ID=Batch 1; reference value for $\mathrm{PbO}$ is $0 \mathrm{wt} \%$

Oneway Analysis of $\mathrm{PbO}$ (wt\%) By Block/Sub-Blk

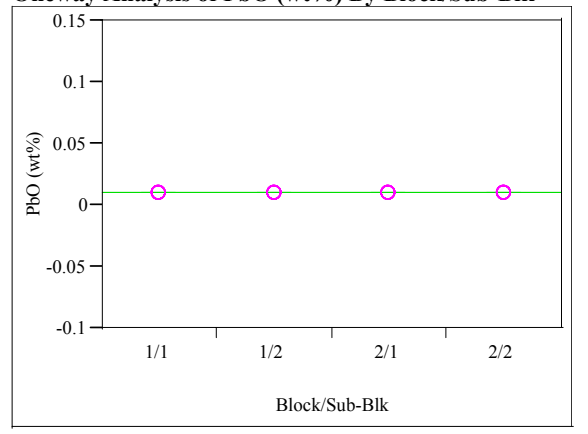

Oneway Anova

Summary of Fit

Rsquare

Root Mean Square Error $\quad 2.12 \mathrm{e}-18$

Mean of Response

0.010772

Observations (or Sum Wgts)

Analysis of Variance

Source DF Sum of Squares

Block/Sub-Blk

Error

C. Total

3 Sum of Squares

11

Level Number Anova

$\begin{array}{lrrr}1 / 1 & \text { Number } & \text { Mean } & \text { Std Error } \\ 1 / 2 & 3 & 0.010772 & 1.227 \mathrm{e}-18\end{array}$

$\begin{array}{llll}1 / 2 & 3 & 0.010772 & 1.227 \mathrm{e}-18\end{array}$

$3 \quad 0.010772 \quad 1.227 \mathrm{e}-18$

$2 / 2 \quad 3 \quad 0.010772 \quad 1.227 \mathrm{e}-18$

Std Error uses a pooled estimate of error variance
Mean Square 0.0000081 0.0000043

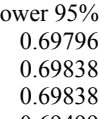

\section{$\%$}

Up

Upper $95 \%$

0.70349

0.70391

0.70391

0.70052
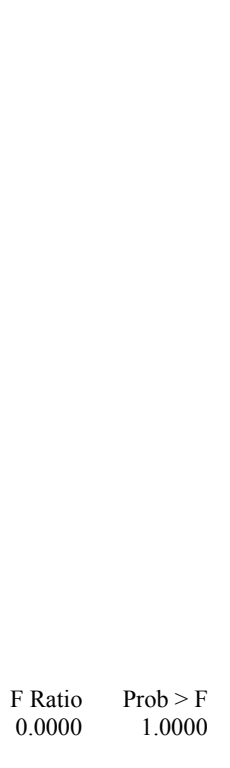

Mean Square

$4.514 \mathrm{e}-36$

Lower 95\%

0.01077

0.01077

0.01077

0.01077

Upper $95 \%$

0.01077

0.01077

0.01077

0.01077
Glass ID=Batch 1; reference value for $\mathrm{SiO} 2$ is $50.22 \mathrm{wt} \%$ Oneway Analysis of $\mathrm{SiO} 2(w \mathrm{t} \%)$ By Block/Sub-Blk

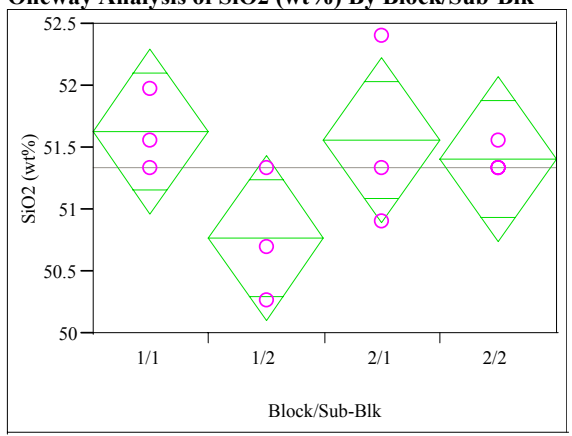

Oneway Anova

Summary of Fit

Rsquare $\quad 0.405405$

Root Mean Square Error $\quad 0.50171$

Mean of Response

51.3432

Observations (or Sum Wgts)

Analysis of Variance

Source DF Sum of Squares

Block/Sub-Blk $\quad 3 \quad 1.3729813$

1.3729813
2.0137060

Mean Square 0.457660 0.251713

C. Total 11 3.3866873

F Ratio Prob $>$ F

Means for Oneway Anova

Level Number Mean Std Error Lower 95\% Upper 95\%

$\begin{array}{lrrrrr}1 / 1 & 3 & 51.6284 & 0.28966 & 50.960 & 52.296\end{array}$

$\begin{array}{llllll}1 / 2 & 3 & 50.7727 & 0.28966 & 50.105 & 51.441\end{array}$

$\begin{array}{llllll}2 / 1 & 3 & 51.5571 & 0.28966 & 50.889 & 52.225\end{array}$

$\begin{array}{llllll}2 / 2 & 3 & 51.4145 & 0.28966 & 50.747 & 52.082\end{array}$

Std Error uses a pooled estimate of error variance

Glass ID $=$ Batch 1; reference value for $\mathrm{ThO} 2$ is $0 \mathrm{wt} \%$

Oneway Analysis of ThO2 (wt\%) By Block/Sub-BIk

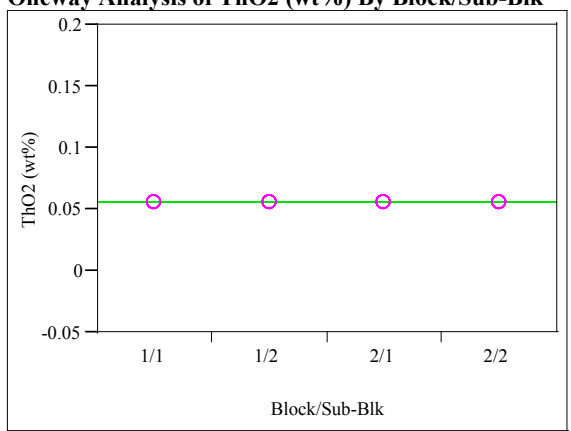

\section{Oneway Anova}

Summary of Fit

Rsquare

Root Mean Square Error $\quad 0$

$\begin{array}{lr}\text { Mean of Response } & 0.056895 \\ \text { Observations (or Sum Wgts) } & 12\end{array}$

Analysis of Variance

Source DF Sum of Squares

$\begin{array}{lr}\text { Source } & \text { DF } \\ \text { Block/Sub-Blk } & 3\end{array}$

Error

C. Total

DF
3
8
11

Sum of Squares
0
0
0

Mean Square

F Ratio Prob $>$ F
Means for Oneway Anova

$\begin{array}{lrrrr}\text { Level } & \text { Number } & \text { Mean } & \text { Std Error } & \text { Lower 95\% } \\ 1 / 1 & 3 & 0.056895 & 0 & 0.05690 \\ 1 / 2 & 3 & 0.056895 & 0 & 0.05690 \\ 2 / 1 & 3 & 0.056895 & 0 & 0.05690 \\ 2 / 2 & 3 & 0.056895 & 0 & 0.05690\end{array}$

Std Error uses a pooled estimate of error variance 


\section{Exhibit D3. SRNL-ML Measurements by Analytical Block for Samples of the Standard Glasses Prepared Using the LM Method}

Glass ID=Batch 1; reference value for $\mathrm{TiO} 2$ is $0.677 \mathrm{wt} \%$ Oneway Analysis of TiO2 (wt\%) By Block/Sub-Blk

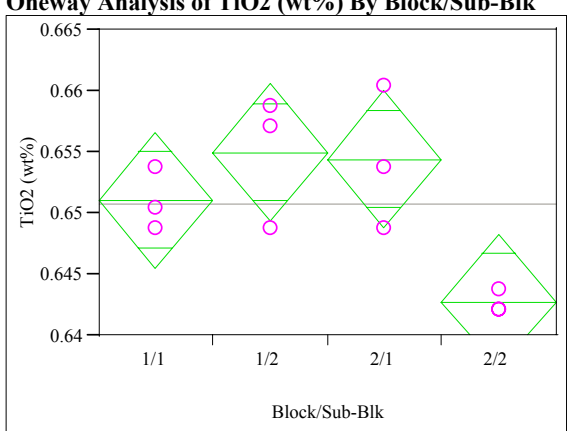

Oneway Anova

Summary of Fit

Rsquare

Root Mean Square Error

0.670282

0.004198

Mean of Response

0.650798

Observations (or Sum Wgts)

Analysis of Variance

Source

Block/Sub-Blk

Error

C. Total

Means for Oneway Anova

Level Number Mean Std Error

$\begin{array}{lrrrr}\text { Level } & \text { Number } & \text { Mean } & \text { Std Error } & \text { Lower 95\% } \\ 1 / 1 & 3 & 0.651076 & 0.00242 & 0.64549 \\ 1 / 2 & 3 & 0.654968 & 0.00242 & 0.64938 \\ 2 / 1 & 3 & 0.654412 & 0.00242 & 0.64882 \\ 2 / 2 & 3 & 0.642736 & 0.00242 & 0.63715\end{array}$

Glass ID=Batch 1; reference value for $\mathrm{U3O8}$ is $0 \mathrm{wt} \%$

Oneway Analysis of U3O8 (wt\%) By Block/Sub-Blk

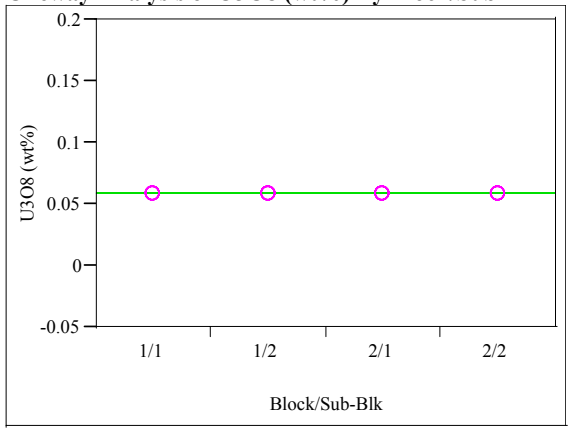

Oneway Anova

Summary of Fit

Rsquare

Root Mean Square Error

Mean of Response

0

Observations (or Sum Wgts)

Analysis of Variance

Source DF Sum of Squares

Block/Sub-Blk

Error

C. Total

$\begin{array}{rr} & \text { Sum of Squares } \\ 3 & 0 \\ 8 & 0 \\ 11 & 0\end{array}$

Means for Oneway Anova

$\begin{array}{lrrrr}\text { Level } & \text { Number } & \text { Mean } & \text { Std Error } & \text { Lower 95\% } \\ 1 / 1 & 3 & 0.058960 & 0 & 0.05896 \\ 1 / 2 & 3 & 0.058960 & 0 & 0.05896 \\ 2 / 1 & 3 & 0.058960 & 0 & 0.05896\end{array}$

$2 / 2 \quad 3 \quad 0.058960$

0.05896
Glass ID=Batch 1; reference value for $\mathrm{ZnO}$ is $0 \mathrm{wt} \%$ Oneway Analysis of $\mathrm{ZnO}(\mathrm{wt} \%)$ By Block/Sub-Blk

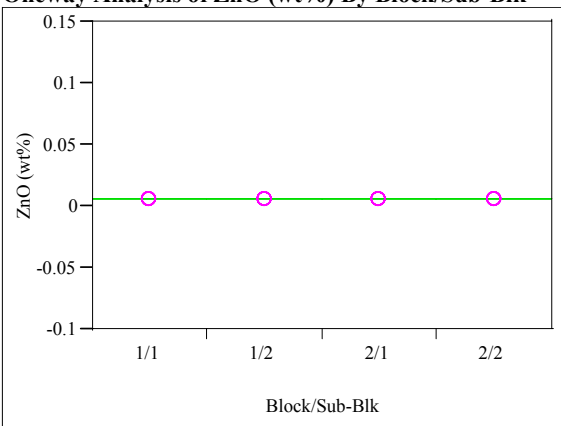

\section{Oneway Anova}

Summary of Fit

Rsquare

Root Mean Square Error $\quad 0$

Mean of Response $\quad 0.006224$

Observations (or Sum Wgts) 12

Analysis of Variance

Prob $>$ F

Source

Block/Sub-Blk

Error

DF
3

Sum of Squares

Mean Square

$\begin{array}{ll}5.4211 & 0.0249\end{array}$

C. Total

8

11

Means for Oneway Anova

Upper $95 \%$

0.65666

0.66056

0.66000

0.64832

$\begin{array}{lrr}\text { Level } & \text { Number } & \text { Mean } \\ 1 / 1 & 3 & 0.006224 \\ 1 / 2 & 3 & 0.006224 \\ 2 / 1 & 3 & 0.006224 \\ 2 / 2 & 3 & 0.006224\end{array}$

$\begin{array}{lcc}2 / 2 & 3 & 0.006224\end{array}$

Glass ID=Batch 1; reference value for $\mathrm{ZrO2}$ is $0.098 \mathrm{wt} \%$

Oneway Analysis of $\mathrm{ZrO2}$ (wt\%) By Block/Sub-Blk

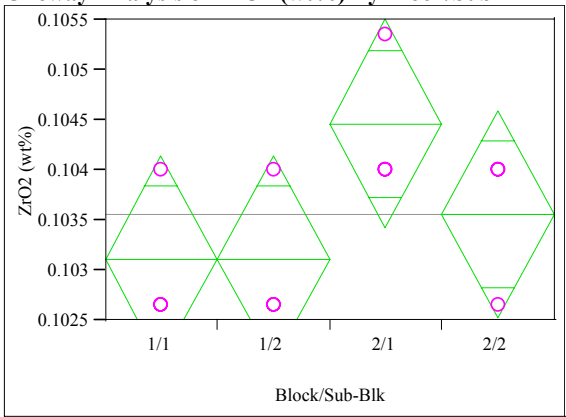

\section{Oneway Anova}

Summary of Fit

Rsquare $\quad 0.428571$

Root Mean Square Error $\quad 0.00078$

Mean of Response

0.00078
0.103561

Observations (or Sum Wgts)

12

Analysis of Variance

Source

F Ratio Prob $>$ F

$\begin{array}{lrr}\text { Block/Sub-Blk } & 3 & 0.00000365\end{array}$

Error

$8 \quad 0.00000487$

C. Total

0.00000852

Means for Oneway Anova

Level Number Mean Std Error Lower 95\% Upper 95\%

Upper 95\%

0.05896

0.05896

0.05896

0.05896

$\begin{array}{lrrr}\text { Level } & \text { Number } & \text { Mean } & \text { Std Error } \\ 1 / 1 & 3 & 0.103111 & 0.00045 \\ 1 / 2 & 3 & 0.10311 & 0.00045 \\ 2 / 1 & 3 & 0.104462 & 0.00045 \\ 2 / 2 & 3 & 0.103561 & 0.00045\end{array}$

Std Error uses a pooled estimate of error variance
Upper $95 \%$ 0.00622 0.00622 0.00622 0.00622 $\begin{array}{rrr}\text { Mean Square } & \text { F Ratio } & \text { Prob }>\text { F } \\ 0.0000012 & 2.0000 & 0.1927\end{array}$ 0.10207 0.10207 0.10342

0.10252
F Ratio Prob $>$ F 


\section{Exhibit D3. SRNL-ML Measurements by Analytical Block for Samples of the Standard Glasses Prepared Using the LM Method}

Glass ID=Ustd, reference value for $\mathrm{Al2O}$ is $4.1 \mathrm{wt} \%$ Oneway Analysis of Al2O3 (wt\%) By Block/Sub-Blk

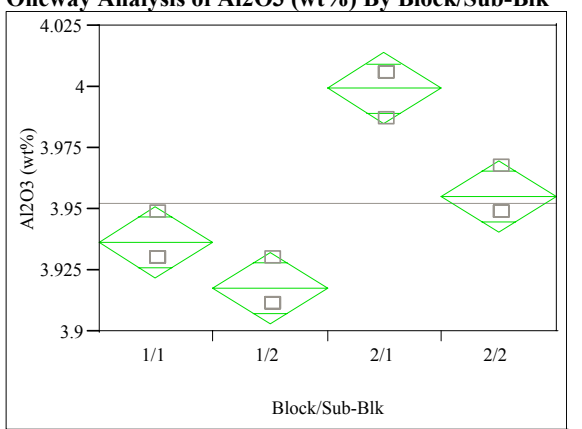

Oneway Anova

Summary of Fit

Rsquare

Root Mean Square Error

0.920792
0.010909
3.952204

Observations (or Sum Wgts)

Analysis of Variance

Source

Block/Sub-Blk

Error

C. Total

Means for Oneway Anova

Level Number

$\begin{array}{lrrrr}\text { Level } & \text { Number } & \text { Mean } & \text { Std Error } & \text { Lower 95\% } \\ 1 / 1 & 3 & 3.93646 & 0.00630 & 3.9219 \\ 1 / 2 & 3 & 3.91756 & 0.00630 & 3.9030 \\ 2 / 1 & 3 & 3.99944 & 0.00630 & 3.9849 \\ 2 / 2 & 3 & 3.95535 & 0.00630 & 3.9408\end{array}$

Std Error uses a pooled estimate of error variance

Glass $\mathrm{ID}=\mathrm{Ustd}$, reference value for $\mathrm{BaO}$ is $0 \mathrm{wt} \%$

Oneway Analysis of $\mathrm{BaO}(\mathrm{wt} \%)$ By Block/Sub-Blk

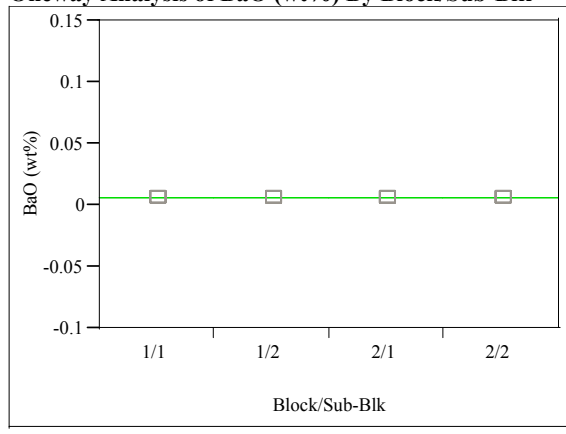

Oneway Anova

Summary of Fit

Rsquare

Root Mean Square Error

Mean of Response

0.00558

Observations (or Sum Wgts)

12

Analysis of Variance

$\begin{array}{ll}\text { Source } & \text { DF } \\ \text { Block/Sub-Blk } & \end{array}$

Error

C. Total

F Sum of Squares

Means for Oneway Anova

Level Number Mean Std Error

$\begin{array}{lrr}1 / 1 & 3 & 0.005583 \\ 1 / 2 & 3 & 0.005583\end{array}$

$\begin{array}{lll}1 / 2 & 3 & 0.005583\end{array}$

$\begin{array}{lll}1 / 2 & 3 & 0.005583\end{array}$

$2 / 2 \quad 3 \quad 0.005583$

Std Error uses a pooled estimate of error variance
Mean Square 0.003689 0.000119

F Ratio Prob $>$ F

31.0000

Upper $95 \%$

3.9510

3.9321

4.0140

3.9699
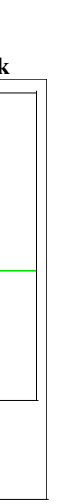

(1)

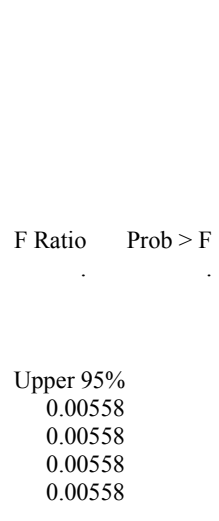

Glass ID=Ustd, reference value for $\mathrm{CaO}$ is $1.301 \mathrm{wt} \%$ Oneway Analysis of $\mathrm{CaO}$ (wt\%) By Block/Sub-Blk

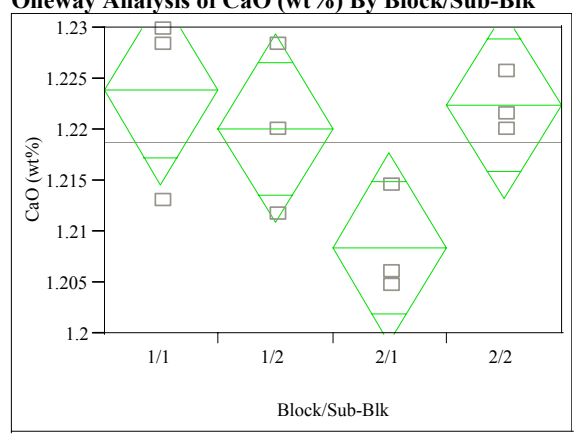

Oneway Anova

Summary of Fit

Rsquare $\quad 0.533019$

Root Mean Square Error $\quad 0.006961$

Mean of Response $\quad 1.218703$

Observations (or Sum Wgts) 12

Analysis of Variance

Source DF Sum of Squares

Block/Sub-Blk 3

0.00044245

0.00038764

Mean Square 0.000147

F Ratio 3.0438

Prob $>$ F

C. Total 11

Means for Oneway Anova

Level Number Mean Std Error Lower 95\% Upper 95\%

$\begin{array}{llllll}1 / 1 & 3 & 1.22383 & 0.00402 & 1.2146 & 1.2331 \\ 1 / 2 & 3 & 1.22010 & 0.00402 & 1.2108 & 1.2294\end{array}$

$\begin{array}{llllll}2 / 1 & 3 & 1.20844 & 0.00402 & 1.1992 & 1.2177\end{array}$

$\begin{array}{llllll}2 / 2 & 3 & 1.22243 & 0.00402 & 1.2132 & 1.2317\end{array}$

Std Error uses a pooled estimate of error variance

Glass ID=Ustd, reference value for $\mathrm{Ce} 2 \mathrm{O} 3$ is $0 \mathrm{wt} \%$

Oneway Analysis of Ce2O3 (wt\%) By Block/Sub-Blk

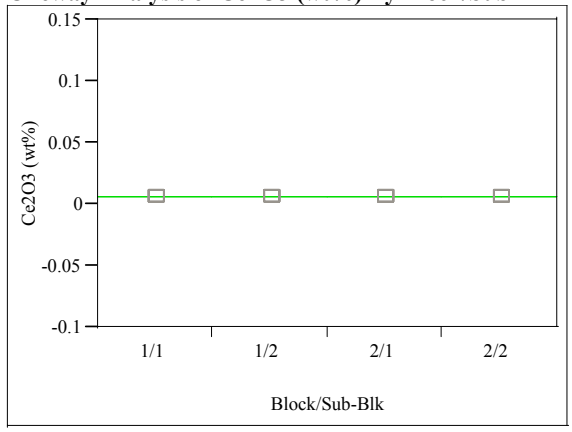

\section{Oneway Anova}

Summary of Fit

Rsquare

Root Mean Square Error $\quad 000$

Observations (or Sum Wgts) 12

Analysis of Variance

$\begin{array}{lrrr}\text { Source } & \text { DF } & \text { Sum of Squares } & \text { Mean Square } \\ \text { Block/Sub-Blk } & 3 & 0 & 0 \\ \text { Error } & 8 & 0 & 0 \\ \text { C. Total } & 11 & 0 & \end{array}$

Anova

Level Mean Std Error

$\begin{array}{lrrrrr}\text { Level } & \text { Number } & \text { Mean } & \text { Std Error } & \text { Lower 95\% } & \text { Upper 95\% } \\ 1 / 1 & 3 & 0.005857 & 0 & 0.00586 & 0.00586 \\ 1 / 2 & 3 & 0.005857 & 0 & 0.00586 & 0.00586 \\ 2 / 1 & 3 & 0.005857 & 0 & 0.00586 & 0.00586 \\ 2 / 2 & 3 & 0.005857 & 0 & 0.00586 & 0.00586\end{array}$




\section{Exhibit D3. SRNL-ML Measurements by Analytical Block for Samples of the Standard Glasses Prepared Using the LM Method}

Glass ID $=$ Ustd, reference value for $\mathrm{Cr} 2 \mathrm{O} 3$ is $0 \mathrm{wt} \%$ Oneway Analysis of Cr2O3 (wt\%) By Block/Sub-Blk

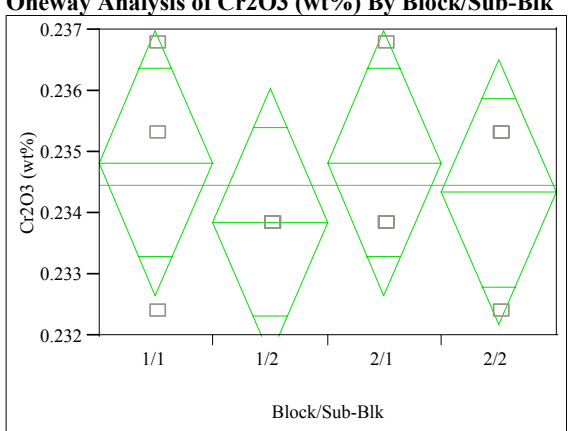

Oneway Anova

Summary of Fit

Rsquare

Root Mean Square Error

0.083969

Mean of Response

0.001634

Observations (or Sum Wgts)

Analysis of Variance

Source

Block/Sub-Blk

Error

C. Total

Means for Oneway Anova

Level Number Mean Std Error

$\begin{array}{lrrrr}\text { Level } & \text { Number } & \text { Mean } & \text { Std Error } & \text { Lower 95\% } \\ 1 / 1 & 3 & 0.234830 & 0.00094 & 0.23265 \\ 1 / 2 & 3 & 0.233856 & 0.00094 & 0.23168 \\ 2 / 1 & 3 & 0.234830 & 0.00094 & 0.23265\end{array}$

$\begin{array}{llll}2 / 2 & 3 & 0.234343 & 0.00094\end{array}$

Std Error uses a pooled estimate of error variance

Glass ID $=$ Ustd, reference value for $\mathrm{CuO}$ is $0 \mathrm{wt} \%$

Oneway Analysis of $\mathrm{CuO}(\mathrm{wt} \%)$ By Block/Sub-Blk

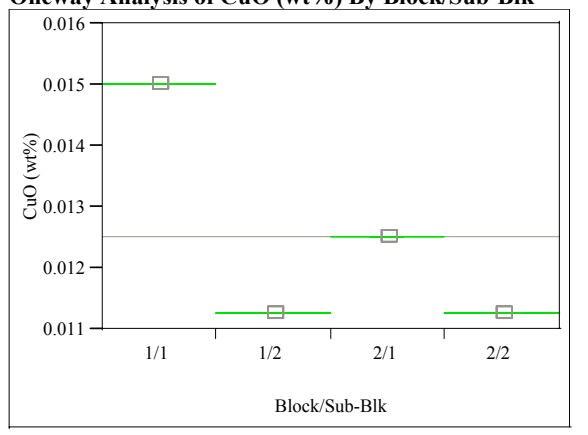

Oneway Anova

Summary of Fit

Rsquare

Root Mean Square Error $\quad 2.91 \mathrm{e}-11$

Mean of Response

Observations (or Sum Wgts)

0.012518

Analysis of Variance

Source

Error

C. Total

$\begin{array}{rr}3 & \text { Sum of Squares } \\ 8 & 0.00002821\end{array}$

0.00000000

0.00002821

Means for Oneway Anova

$\begin{array}{lrrrrr}\text { Level } & \text { Number } & \text { Mean } & \text { Std Error } & \text { Lower 95\% } & \text { Upper 95\% } \\ 1 / 1 & 3 & 0.015022 & 1.68 \mathrm{e}-11 & 0.01502 & 0.01502 \\ 1 / 2 & 3 & 0.011266 & 1.68 \mathrm{e}-11 & 0.01127 & 0.01127 \\ 2 / 1 & 3 & 0.012518 & 1.68 \mathrm{e}-11 & 0.01252 & 0.01252 \\ 2 / 2 & 3 & 0.011266 & 1.68 \mathrm{e}-11 & 0.01127 & 0.01127\end{array}$

Std Error uses a pooled estimate of error variance

Upper 95\%

0.23701

0.23603

0.23701

0.23652

F Ratio

0.0000094

$1.11 \mathrm{e}+16$
Glass ID=Ustd, reference value for Fe2O3 is $13.196 \mathrm{wt} \%$ Oneway Analysis of Fe2O3 (wt\%) By Block/Sub-Blk

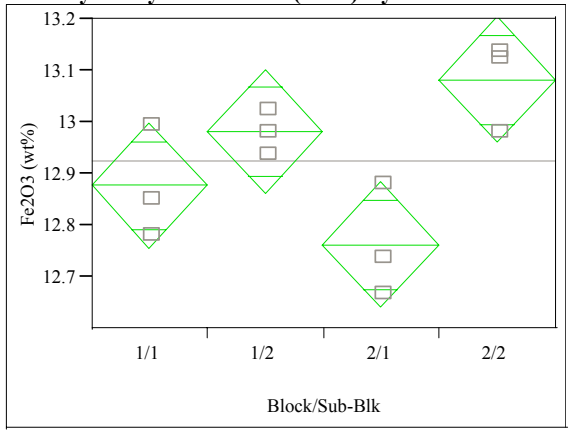

Oneway Anova

Summary of Fit

Rsquare $\quad 0.718306$

Root Mean Square Error $\quad 0.091173$

Mean of Response $\quad 12.92568$

Observations (or Sum Wgts)

Analysis of Variance

Source DF Sum of Squares

Block/St

$\begin{array}{rrr}6.5275 \mathrm{e}-7 & 0.2444 & 0.8630\end{array}$

Block/S

0.16957033

0.06649950

Mean Square

0.056523

0.008312

F Ratio

Prob $>$ F

C. Total

0.23606983

Means for Oneway Anova

Level Number Mean Std Error $\quad$ Lower 95\% Upper 95\%

$\begin{array}{lrrrrr}1 / 1 & 3 & 12.8768 & 0.05264 & 12.755 & 12.998\end{array}$

$\begin{array}{llllll}1 / 2 & 3 & 12.9817 & 0.05264 & 12.860 & 13.103\end{array}$

$\begin{array}{llllll}2 / 1 & 3 & 12.7625 & 0.05264 & 12.641 & 12.884\end{array}$

$\begin{array}{llllll}2 / 2 & 3 & 13.0818 & 0.05264 & 12.960 & 13.203\end{array}$

Std Error uses a pooled estimate of error variance

Glass ID=Ustd, reference value for $\mathrm{K2O}$ is $2.999 \mathrm{wt} \%$

Oneway Analysis of K2O (wt\%) By Block/Sub-Blk

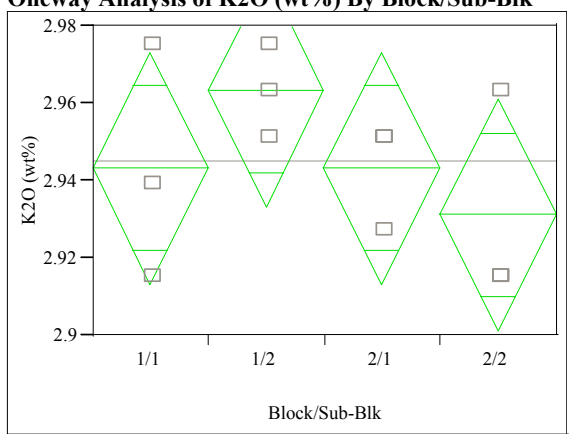

Oneway Anova

Summary of Fit

Rsquare

0.282051

Root Mean Square Error

0.022536

Mean of Response

2.945247

Observations (or Sum Wgts)

Analysis of Varianc

Prob $>$ F

Source

Block/Sub-Blk

Error

DF

Sum of Squares

C. Total 0.00159617

0.00406297

Mean Square 0.000532 0.000508

F Ratio 1.0476

Prob $>$ F

Means for Oneway Anova

$\begin{array}{lrrr}\text { Level } & \text { Number } & \text { Mean } & \text { Std Error } \\ 1 / 1 & 3 & 2.94324 & 0.01301 \\ 1 / 2 & 3 & 2.96332 & 0.01301 \\ 2 / 1 & 3 & 2.94324 & 0.01301 \\ 2 / 2 & 3 & 2.93119 & 0.01301\end{array}$

Lower $95 \%$

2.9132

2.9333

2.9132

2.9012

Std Error uses a pooled estimate of error variance
Upper 95\%

2.9732

2.9933

2.9732

2.9612 


\section{Exhibit D3. SRNL-ML Measurements by Analytical Block for Samples of the Standard Glasses Prepared Using the LM Method}

Glass ID=Ustd, reference value for $\mathrm{La2O3}$ is $0 \mathrm{wt} \%$ Oneway Analysis of La2O3 (wt\%) By Block/Sub-Blk

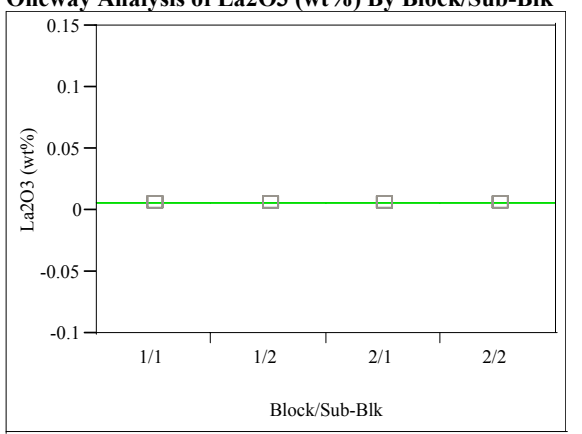

\section{Oneway Anova}

Summary of Fit

Rsquare

Root Mean Square Error

Mean of Response

Observations (or Sum Wgts)

Analysis of Variance

Source

Block/Sub-Blk

Error

C. Total

Oneway Anova

$\begin{array}{lrrrr}\text { Level } & \text { Number } & \text { Mean } & \text { Std Error } & \text { Lower 95\% } \\ 1 / 1 & 3 & 0.005864 & 0 & 0.00586 \\ 1 / 2 & 3 & 0.005864 & 0 & 0.00586 \\ 2 / 1 & 3 & 0.005864 & 0 & 0.00586\end{array}$

$\begin{array}{lllll}2 / 2 & 3 & 0.005864 & 0 & 0.00586\end{array}$

Std Error uses a pooled estimate of error variance

Glass ID=Ustd, reference value for $\mathrm{MgO}$ is $1.21 \mathrm{wt} \%$

Oneway Analysis of $\mathrm{MgO}(\mathrm{wt} \%)$ By Block/Sub-Blk

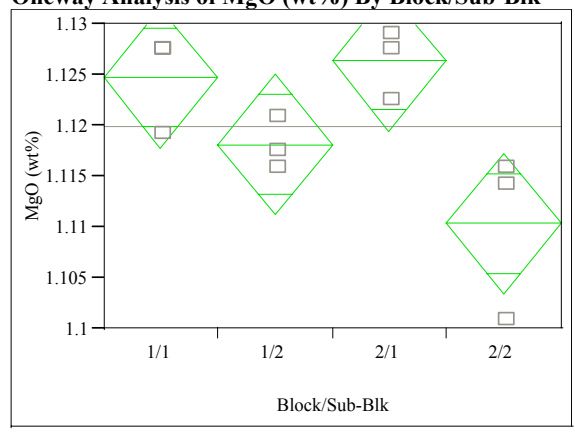

Oneway Anova

Summary of Fit

Rsquare

0.688962

Root Mean Square Error

0.005199

Mean of Response

1.119908

Observations (or Sum Wgts)

Analysis of Variance

Source

DF Sum of Squares

$\begin{array}{lll} & 3 & 0.00047906\end{array}$

$\begin{array}{lll}\text { Error } & 8 & 0.00021628\end{array}$

C. Total

11

0.00069534

Means for Oneway Anova

Level Number Mean Std Error

$\begin{array}{lrrr}1 / 1 & 3 & 1.12474 & 0.00300\end{array}$

$\begin{array}{llll}1 / 2 & 3 & 1.11811 & 0.00300\end{array}$

$\begin{array}{llll}2 / 1 & 3 & 1.12640 & 0.00300\end{array}$

$\begin{array}{llll}2 / 2 & 3 & 1.11037 & 0.00300\end{array}$

Std Error uses a pooled estimate of error variance

0.000027
Glass ID=Ustd, reference value for $\mathrm{MnO}$ is $\mathbf{2 . 8 9 2} \mathrm{wt} \%$ Oneway Analysis of $\mathrm{MnO}$ (wt\%) By Block/Sub-Blk

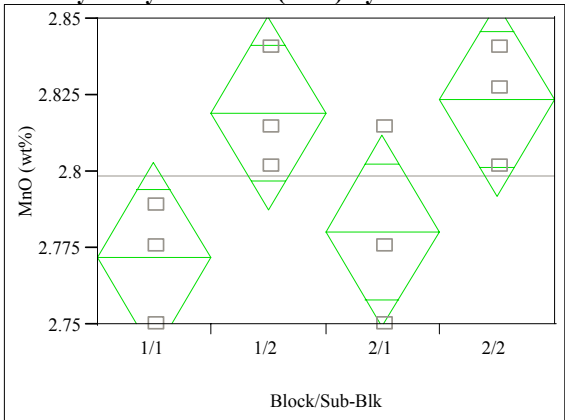

Oneway Anova

Summary of Fit

$\begin{array}{ll}\text { Rsquare } & 0.584955 \\ \text { Root } & 0.023574\end{array}$

Mean of Response

0.023574

Observations (or Sum Wgts)

Analysis of Variance

Block/Sub-Blk DF

Error

Sum of Squares 0.00626588

0.00444586

Mean Square 0.002089

F Ratio 3.7583

Prob $>$ F

$\begin{array}{lll}\text { C. Total } & 11 & 0.01071174\end{array}$

Means for Oneway Anova

Level Number Mean Std Error $\quad$ Lower 95\% Upper 95\%

Upper $95 \%$ 0.00586

0.00586

0.00586

0.00586

$\begin{array}{lllll}1 / 2 & 3 & 2.81912 & 0.01361 & 2.7877\end{array}$

$\begin{array}{lllll}2 / 1 & 3 & 2.78038 & 0.01361 & 2.7490\end{array}$

$\begin{array}{ccc}3 / 2 & 2.82342 & 0.01361 \\ \text { Std Error uses a pooled estimate of error variance }\end{array}$

Glass ID=Ustd, reference value for $\mathrm{Na2O}$ is $11.795 \mathrm{wt} \%$ Oneway Analysis of Na2O(wt\%) By Block/Sub-Blk

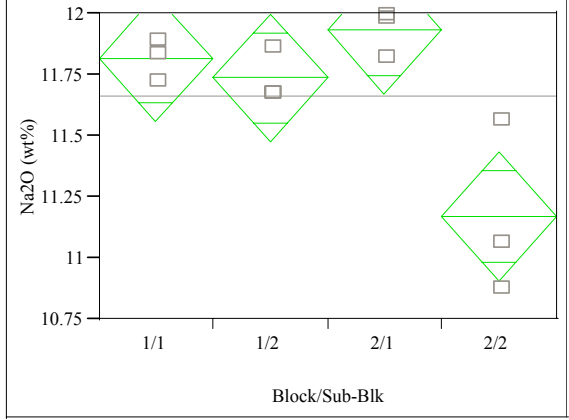

Oneway Anova

Summary of Fit

Rsquare

0.770533

Root Mean Square Error

0.196426

Mean of Response

11.66469

Observations (or Sum Wgts)

Analysis of Variance

Source DF Sum of Squares

Mean Square F Ratio Prob $>$ F

5.9068

0.0200

Error

3

1.0364761

Mean Square 0.345492

C. Total

0.3086654

0.038583

F Ratio

8.9545

Prob $>$ F

Means for Oneway Anova

Lower 95\% Upper 95\%

$\begin{array}{lr}1.1178 & 1.1317\end{array}$

$1.1112-1.1250$

1.1333

$\begin{array}{ll}1.1195 & 1.1333 \\ 1.1035 & 1.1173\end{array}$

$$
\begin{array}{lrrc}
\text { Level } & \text { Number } & \text { Mean } & \text { Std Error } \\
1 / 1 & 3 & 11.8175 & 0.11341 \\
1 / 2 & 3 & 11.7366 & 0.11341 \\
2 / 1 & 3 & 11.9343 & 0.11341 \\
2 / 2 & 3 & 11.1704 & 0.11341 \\
\multicolumn{4}{l}{\text { Std Error uses a pooled estimate of error variance }}
\end{array}
$$




\section{Exhibit D3. SRNL-ML Measurements by Analytical Block for Samples of the Standard Glasses Prepared Using the LM Method}

Glass ID=Ustd, reference value for $\mathrm{NiO}$ is $1.12 \mathrm{wt} \%$ Oneway Analysis of $\mathrm{NiO}(\mathrm{wt} \%)$ By Block/Sub-Blk

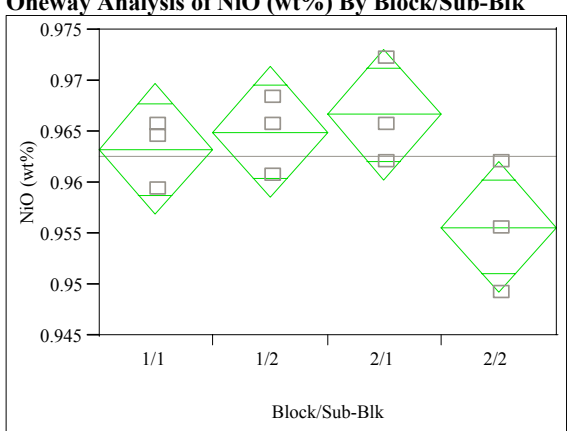

Oneway Anova

Summary of Fit

Rsquare

Root Mean Square Error

0.533063

Mean of Response

0.004832

0.962646

Observations (or Sum Wgts)

Analysis of Variance

Source

Block/Sub-Blk

Error

C. Total

Means for Oneway Anova

Level Number Mean Std Error

$0.963282+0.00279$

$\begin{array}{llll}1 / 1 & 3 & 0.963282 & 0.00279\end{array}$

$\begin{array}{llll}1 / 2 & 3 & 0.964979 & 0.00279\end{array}$

$\begin{array}{llll}2 / 1 & 3 & 0.966676 & 0.00279\end{array}$

$3 \quad 0.955647 \quad 0.00279$

Std Error uses a pooled estimate of error variance

Glass ID $=$ Ustd, reference value for $\mathrm{PbO}$ is $0 \mathrm{wt} \%$

Oneway Analysis of $\mathrm{PbO}$ (wt\%) By Block/Sub-Blk

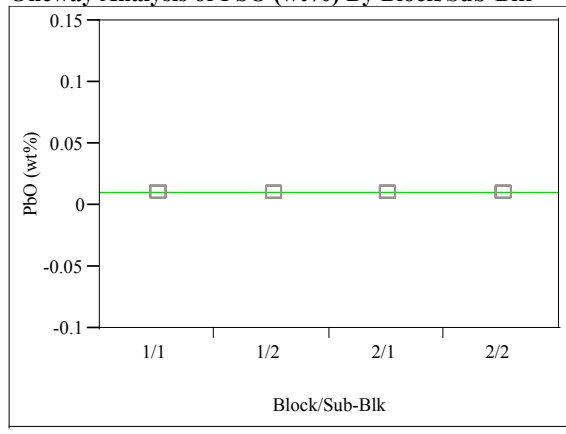

Oneway Anova

Summary of Fit

Rsquare

Root Mean Square Error $\quad 2.12 \mathrm{e}-18$

Mean of Response

0.010772

Observations (or Sum Wgts)

Analysis of Variance

Source DF Sum of Squares

Block/Sub-Blk

Error

C. Total

3 Sum of Squares

11

Level Number Anova

$\begin{array}{lrrr}1 / 1 & \text { Number } & \text { Mean } & \text { Std Error } \\ 1 / 2 & 3 & 0.010772 & 1.227 \mathrm{e}-18\end{array}$

$\begin{array}{llll}1 / 2 & 3 & 0.010772 & 1.227 \mathrm{e}-18\end{array}$

$3 \quad 0.010772 \quad 1.227 \mathrm{e}-18$

$2 / 2 \quad 3 \quad 0.010772 \quad 1.227 \mathrm{e}-18$

Std Error uses a pooled estimate of error variance
Mean Square 0.000071 0.000023

Lower 95\% 0.95685 0.95855 0.96024 0.94921

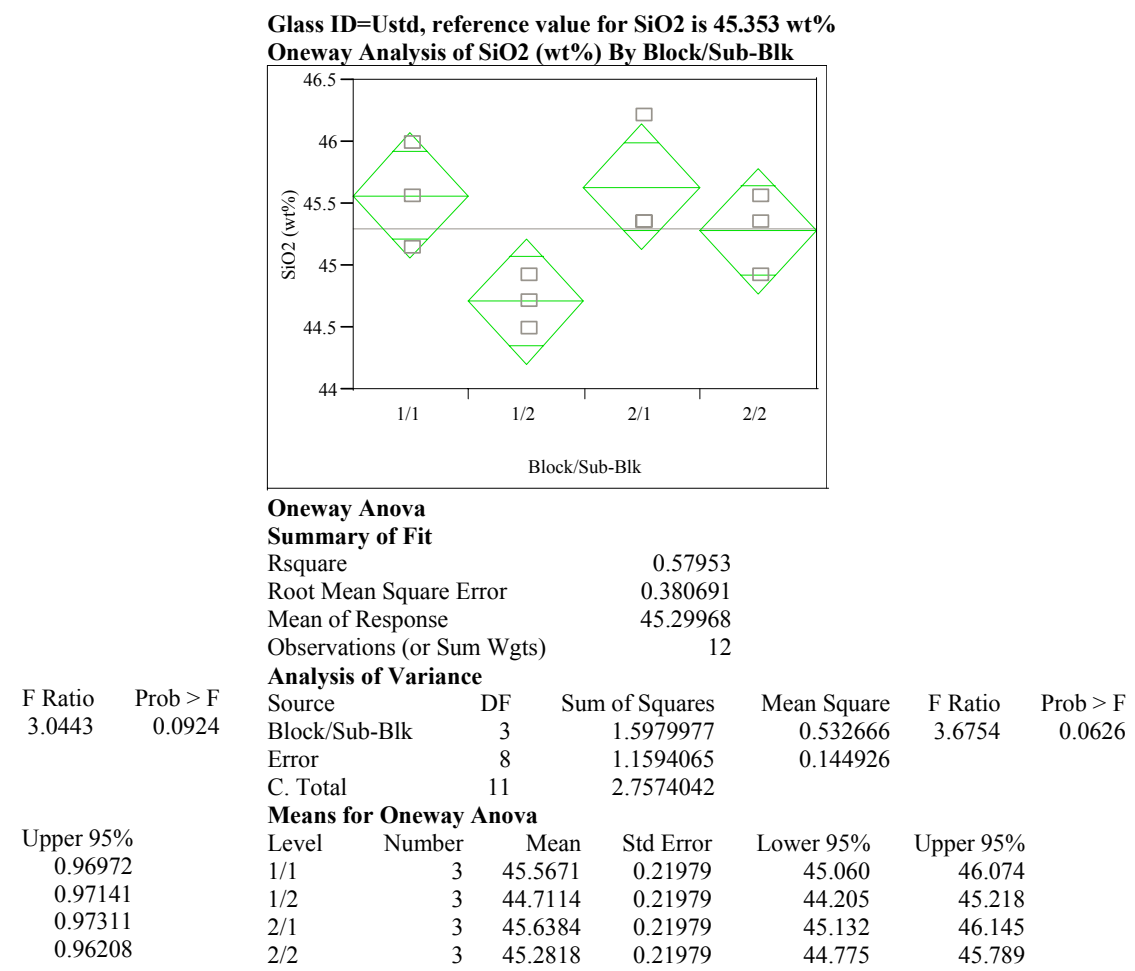

Std Error uses a pooled estimate of error variance

Glass ID $=$ Ustd, reference value for $\mathrm{ThO2}$ is $0 \mathrm{wt} \%$

Oneway Analysis of ThO2 (wt\%) By Block/Sub-Blk

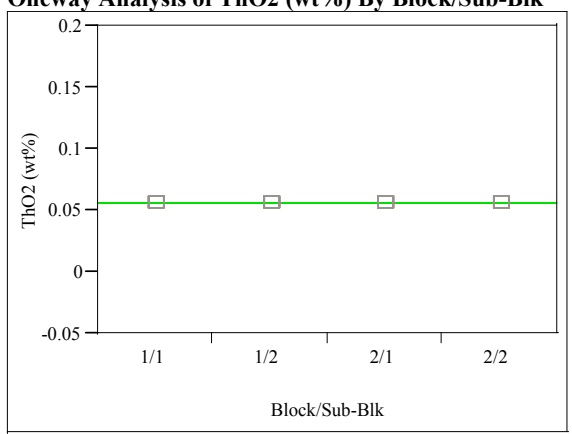

Oneway Anova

Summary of Fit

Rsquare

Root Mean Square Error 0

$\begin{array}{lr}\text { Mean of Response } & 0.056895 \\ \text { Observations (or Sum Wgts) } & 12\end{array}$

Analysis of Variance

Mean Square F Ratio Prob $>$ F

Source

$4.514 \mathrm{e}-36$

0.0000

1.0000

Lower 95\% Upper 95\%

0.01077

0.01077

0.01077

0.01077

0.01077

0.01077

0.01077
Block

Error

C. Total

Means for Oneway Anova

$\begin{array}{lrrrr}\text { Level } & \text { Number } & \text { Mean } & \text { Std Error } & \text { Lower 95\% } \\ 1 / 1 & 3 & 0.056895 & 0 & 0.05690 \\ 1 / 2 & 3 & 0.056895 & 0 & 0.05690 \\ 2 / 1 & 3 & 0.056895 & 0 & 0.05690 \\ 2 / 2 & 3 & 0.056895 & 0 & 0.05690\end{array}$

Std Error uses a pooled estimate of error variance
Mean Square F Ratio Prob $>$ F

F Ratio Prob $>$ F 


\section{Exhibit D3. SRNL-ML Measurements by Analytical Block for Samples of the Standard Glasses Prepared Using the LM Method}

Glass ID=Ustd, reference value for $\mathrm{TiO} 2$ is $1.409 \mathrm{wt} \%$ Oneway Analysis of TiO2 (wt\%) By Block/Sub-Blk

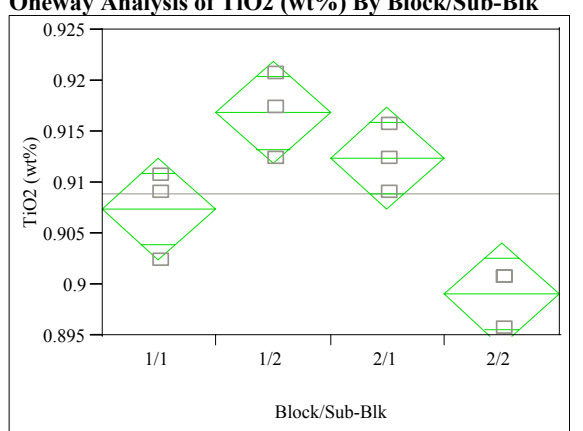

Oneway Anova

Summary of Fit

Rsquare

Root Mean Square Error

0.822352

Mean of Response

0.003761

Observations (or Sum Wgts)

Analysis of Variance

Source

Block/Sub-Blk

Error

C. Total

Means for Oneway Anova

Level Number Mean Std Error

$\begin{array}{lrrrr}\text { Level } & \text { Number } & \text { Mean } & \text { Std Error } & \text { Lower 95\% } \\ 1 / 1 & 3 & 0.907392 & 0.00217 & 0.90239 \\ 1 / 2 & 3 & 0.916844 & 0.00217 & 0.91184 \\ 2 / 1 & 3 & 0.912396 & 0.00217 & 0.90739 \\ 2 / 2 & 3 & 0.899052 & 0.00217 & 0.89405\end{array}$

Std Error uses a pooled estimate of error variance

Glass ID=Ustd, reference value for $\mathrm{U} 308$ is $2.406 \mathrm{wt} \%$

Oneway Analysis of U3O8 (wt\%) By Block/Sub-Blk

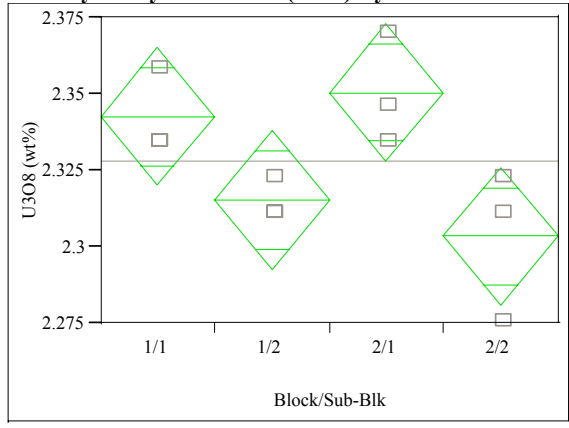

Oneway Anova

Summary of Fit

Rsquare

0.659284

0.01702

Root Mean Square Erro

2.327937

ean of Response

12

Analysis of Variance

Source

DF Sum of Square

$\begin{array}{lll} & 3 & 0.00448440\end{array}$

Error

C. Total

0.00231752

0.00680192

Means for Oneway Anova

$\begin{array}{lrrrrr}\text { Level } & \text { Number } & \text { Mean } & \text { Std Error } & \text { Lower 95\% } & \text { Upper 95\% } \\ 1 / 1 & 3 & 2.34268 & 0.00983 & 2.3200 & 2.3653 \\ 1 / 2 & 3 & 2.31516 & 0.00983 & 2.2925 & 2.3378 \\ 2 / 1 & 3 & 2.35054 & 0.00983 & 2.3279 & 2.3732 \\ 2 / 2 & 3 & 2.30337 & 0.00983 & 2.2807 & 2.3260\end{array}$

0.000175

0.000014

12.3443

Upper $95 \%$

0.91240

0.92185

0.91740

0.90406 0.001495 0.000290

5.1600
Glass ID=Ustd, reference value for $\mathrm{ZnO}$ is $\mathbf{0 ~ w t} \%$ Oneway Analysis of $\mathrm{ZnO}$ (wt\%) By Block/Sub-Blk

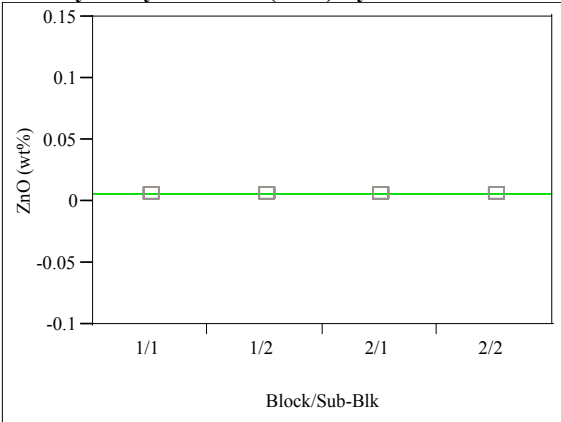

\section{Oneway Anova}

Summary of Fit

Rsquare

Root Mean Square Error 0

Mean of Response $\quad 0.006224$

Observations (or Sum Wgts) 12

Analysis of Variance

Source

F Ratio Prob $>$ F

0.0023

Error

DF

Sum of Squares

12

C. Total

8

Means for Oneway Anova

Level Number

$\begin{array}{lrrrr}\text { Level } & \text { Number } & \text { Mean } & \text { Std Error } & \text { Lower 95\% } \\ 1 / 1 & 3 & 0.006224 & 0 & 0.00622 \\ 1 / 2 & 3 & 0.006224 & 0 & 0.00622 \\ 2 / 1 & 3 & 0.006224 & 0 & 0.00622 \\ 2 / 2 & 3 & 0.006224 & 0 & 0.00622\end{array}$

$\begin{array}{lccc}2 / 2 & 3 & 0.006224 & 0 \\ \text { Std Error uses a pooled estimate of error variance }\end{array}$

Glass ID=Ustd, reference value for $\mathrm{ZrO2}$ is $0 \mathrm{wt} \%$

Oneway Analysis of $\mathrm{ZrO2}$ (wt\%) By Block/Sub-BIk

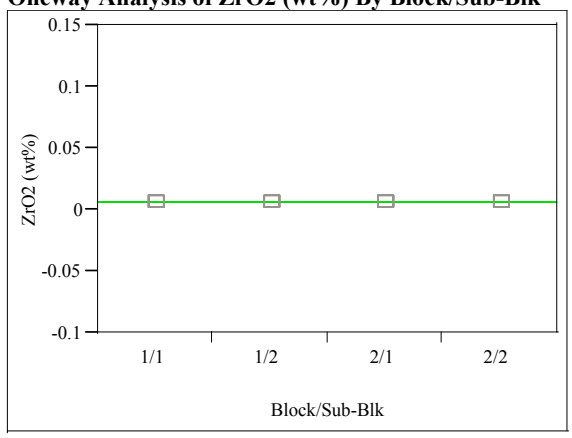

\section{Oneway Anova}

Summary of Fit

Rsquare

Root Mean Square Error $\quad 0$

Mean of Response $\quad 0.006754$

Observations (or Sum Wgts)

Analysis of Variance

Source

Mean Square F Ratio Prob $>$ F

0.0283

Source DF

Error

C. Total

DF
3
8

Sum of Squares

Means for Oneway Amova

Means for Oneway Anova

$\begin{array}{lrrrrr}\text { Level } & \text { Number } & \text { Mean } & \text { Std Error } & \text { Lower 95\% } & \text { Upper 95\% } \\ 1 / 1 & 3 & 0.006754 & 0 & 0.00675 & 0.00675 \\ 1 / 2 & 3 & 0.006754 & 0 & 0.00675 & 0.00675 \\ 2 / 1 & 3 & 0.006754 & 0 & 0.00675 & 0.00675\end{array}$

$\begin{array}{llllll}2 / 2 & 3 & 0.006754 & 0 & 0.00675 & 0.00675 \\ & 3 & 0 & 0.0675 & 0.00675\end{array}$
Mean Square F Ratio Prob $>$ F

Upper 95\% 0.00622 0.00622 0.00622 0.00622 


\section{Exhibit D4. SRNL-ML Measurements by Analytical Block for Samples of the Standard Glasses Prepared Using the PF Method}

Glass ID=Batch 1, reference value for $\mathrm{B} 2 \mathrm{O3}$ is $7.777 \mathrm{wt} \%$ Oneway Analysis of B2O3 (wt\%) By Block/Sub-Blk

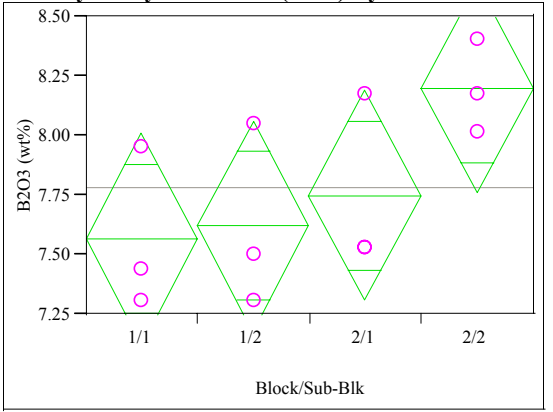

Oneway Anova

Summary of Fit

Rsquare

Root Mean Square Error

Mean of Response

Observations (or Sum Wgts)

Analysis of Variance

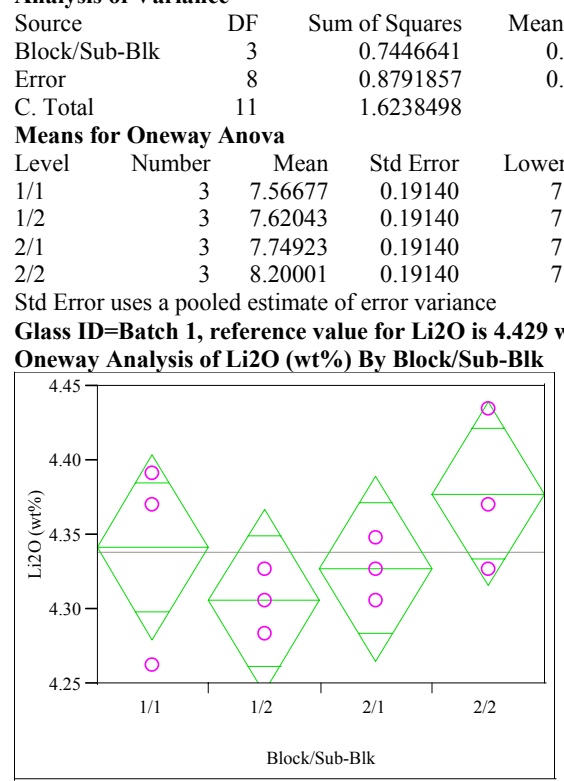

Oneway Anova

Summary of Fit

Rsquare

0.321212

Root Mean Square Error

0.046508

Mean of Response

4.338093

Observations (or Sum Wgts)

Analysis of Variance

\begin{tabular}{|c|c|c|c|}
\hline Source & & DF & of Squares \\
\hline Block/Sul & Blk & 3 & 0.00818846 \\
\hline Error & & 8 & 0.01730392 \\
\hline C. Total & & 11 & 0.02549238 \\
\hline Means fo & Oneway & Anova & \\
\hline Level & Number & Mean & Std Error \\
\hline $1 / 1$ & 3 & 4.34168 & 0.02685 \\
\hline $1 / 2$ & 3 & 4.30580 & 0.02685 \\
\hline $2 / 1$ & 3 & 4.32733 & 0.02685 \\
\hline $2 / 2$ & 3 & 4.37756 & 0.02685 \\
\hline
\end{tabular}

Mean Square
0.002729
0.002163


Lower $95 \%$
4.2798
4.2439
4.2654
4.3156

F Ratio Prob $>$ F \begin{tabular}{ll}
$1.2619 \quad 0.3508$ \\
\hline
\end{tabular}

Upper 95\%

4.4036

4.3677

4.3892

4.4395
Glass ID=Ustd, reference value for $\mathrm{B2O3}$ is $9.209 \mathrm{wt} \%$ Oneway Analysis of B2O3 (wt\%) By Block/Sub-Blk

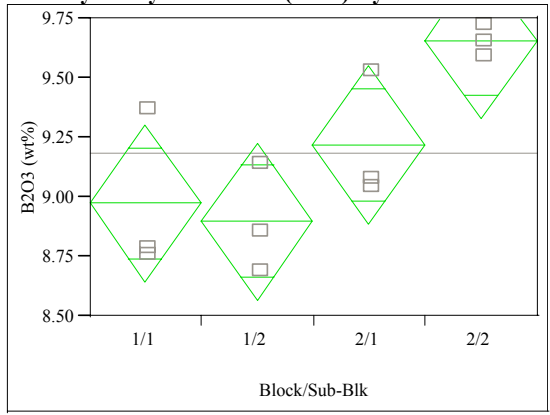

Oneway Anova

Summary of Fit

Rsquare

0.681899

Root Mean Square Error

0.248892

Mean of Response

9.187448

Observations (or Sum Wgts)

Analysis of Variance

Source DF Sum of Squares

Block/Sub-Blk $\quad 3$

Error

Sum of Square

1.0623494
0.4955787

Mean Square 0.354116

F Ratio 5.7164

Prob $>$ F

C. Total

Means for Oneway Anova

Level Number Mean Std Error Lower 95\% Upper 95\%

$\begin{array}{lll}3 & 8.97279 & 0.14370\end{array}$

$\begin{array}{lllll}1 / 2 & 3 & 8.89766 & 0.14370 & 8.5663\end{array}$

$\begin{array}{lllll}1 / 2 & 3 & 8.89766 & 0.14370 & 8.5663 \\ 2 / 1 & 3 & 9.21965 & 0.14370 & 8.8883\end{array}$

$\begin{array}{lllll}2 / 2 & 3 & 9.65970 & 0.14370 & 9.3283\end{array}$

Std Error uses a pooled estimate of error variance

Glass ID=Batch 1, reference value for $\mathrm{Li} 2 \mathrm{O}$ is $3.057 \mathrm{wt} \%$ Oneway Analysis of Li2O (wt\%) By Block/Sub-Blk

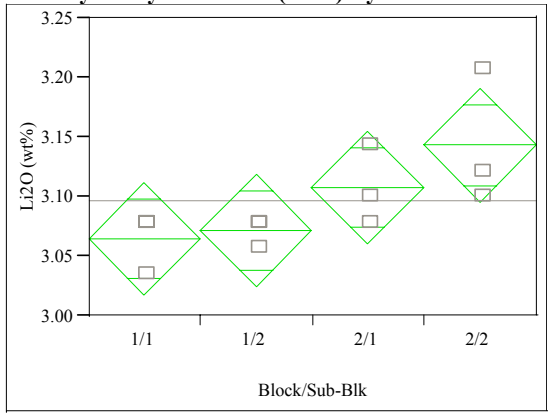

\section{Oneway Anova}

Summary of Fit

Root Mean Square Error $\quad 0.035702$

Mean of Response $\quad 3.096588$

Observations (or Sum Wgts) 12

Analysis of Variance

\begin{tabular}{lrrrr} 
Source & DF & Sum of Squares & Mean Square \\
Block/Sub-Blk & 3 & 0.01189644 & 0.003965 \\
Error & 8 & 0.01019695 & 0.001275 \\
C. Total & 11 & 0.02209340 & \\
\multicolumn{4}{l}{ Means for Oneway Anova } & \\
Level & Number & Mean & Std Error & Lower 95\% \\
$1 / 1$ & 3 & 3.06429 & 0.02061 & 3.0168 \\
$1 / 2$ & 3 & 3.07147 & 0.02061 & 3.0239 \\
$2 / 1$ & 3 & 3.10735 & 0.02061 & 3.0598 \\
$2 / 2$ & 3 & 3.14323 & 0.02061 & 3.0957
\end{tabular}

F Ratio Prob $>$ F $3.1111 \quad 0.0885$

9.2290

9.5510

9.991
Upper 95\%

3.1118

3.1190

3.1549

Std Error uses a pooled estimate of error variance

Std Error uses a pooled estimate of error variance 


\section{Exhibit D5. Measured and Measured Bias-Corrected Oxide Weight Percents by Glass ID for the Glasses Prepared Using the LM Method}

$\mathrm{Al2O3}(\mathrm{wt} \%)$ By Glass ID

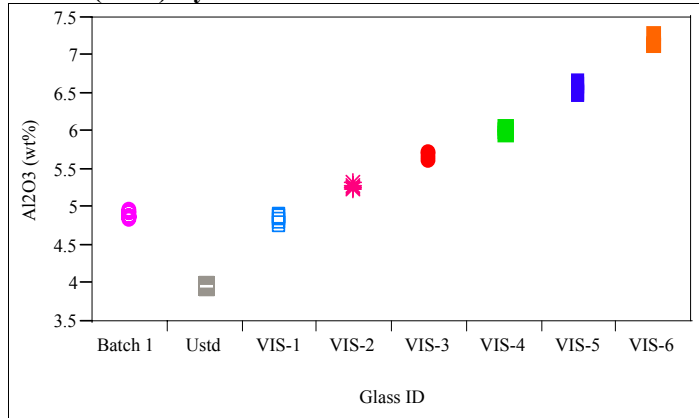

BaO (wt\%) By Glass ID

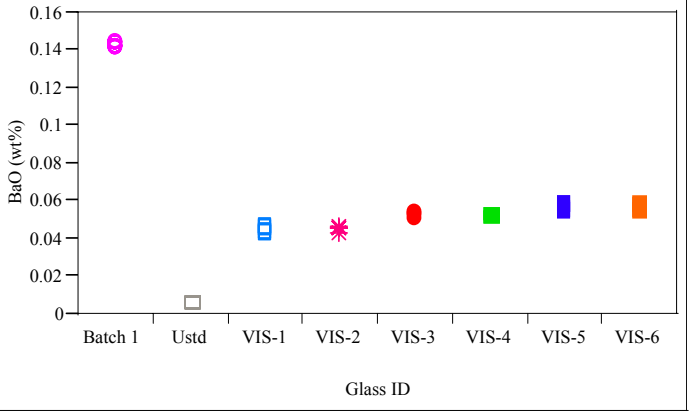

CaO (wt\%) By Glass ID

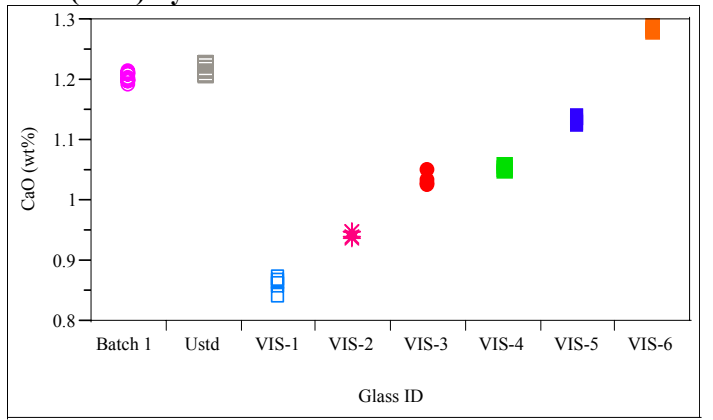

Ce2O3 (wt\%) By Glass ID

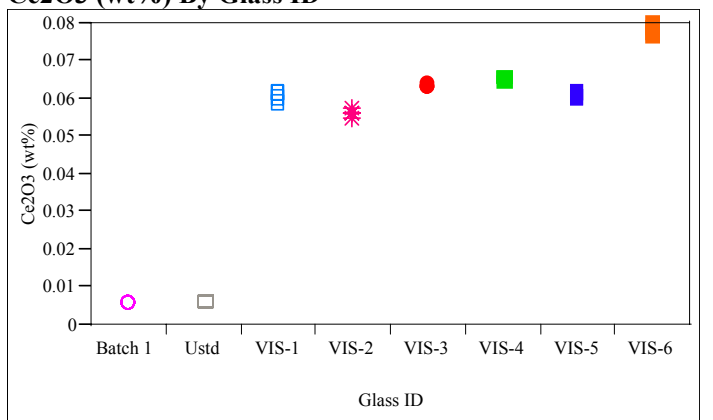

Cr2O3 (wt\%) By Glass ID
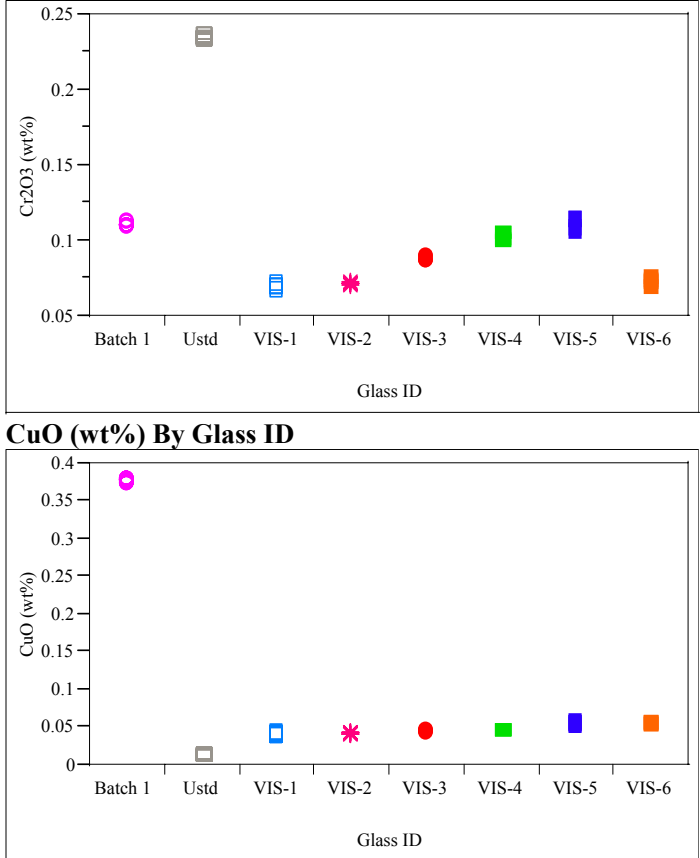

Fe2O3 (wt\%) By Glass ID

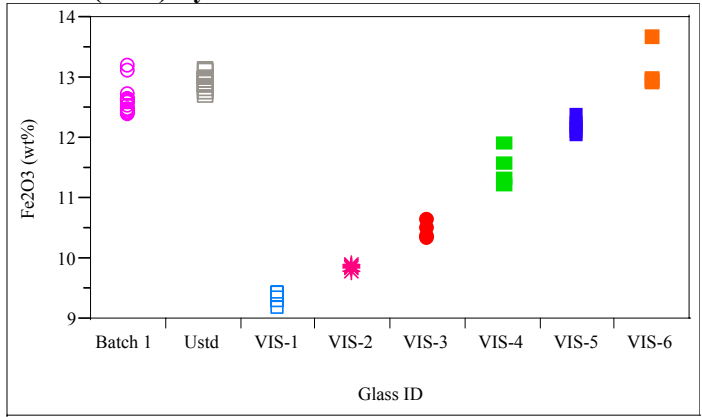

K2O (wt\%) By Glass ID

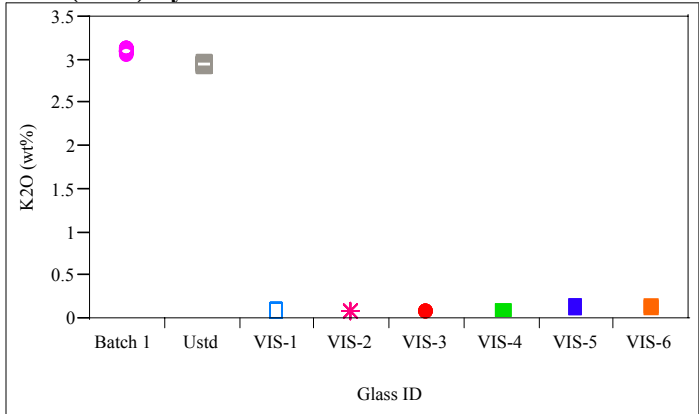




\section{Exhibit D5. Measured and Measured Bias-Corrected Oxide Weight Percents by Glass ID for the Glasses Prepared Using the LM Method}
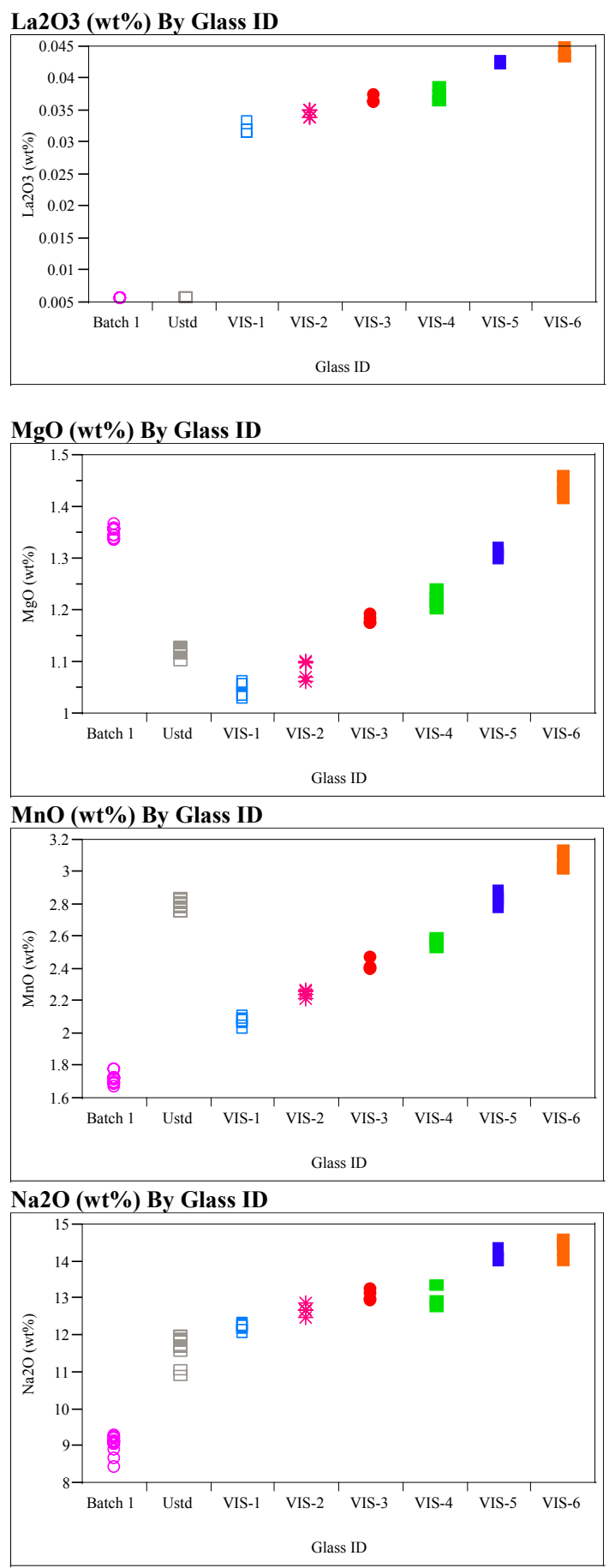

NiO (wt\%) By Glass ID
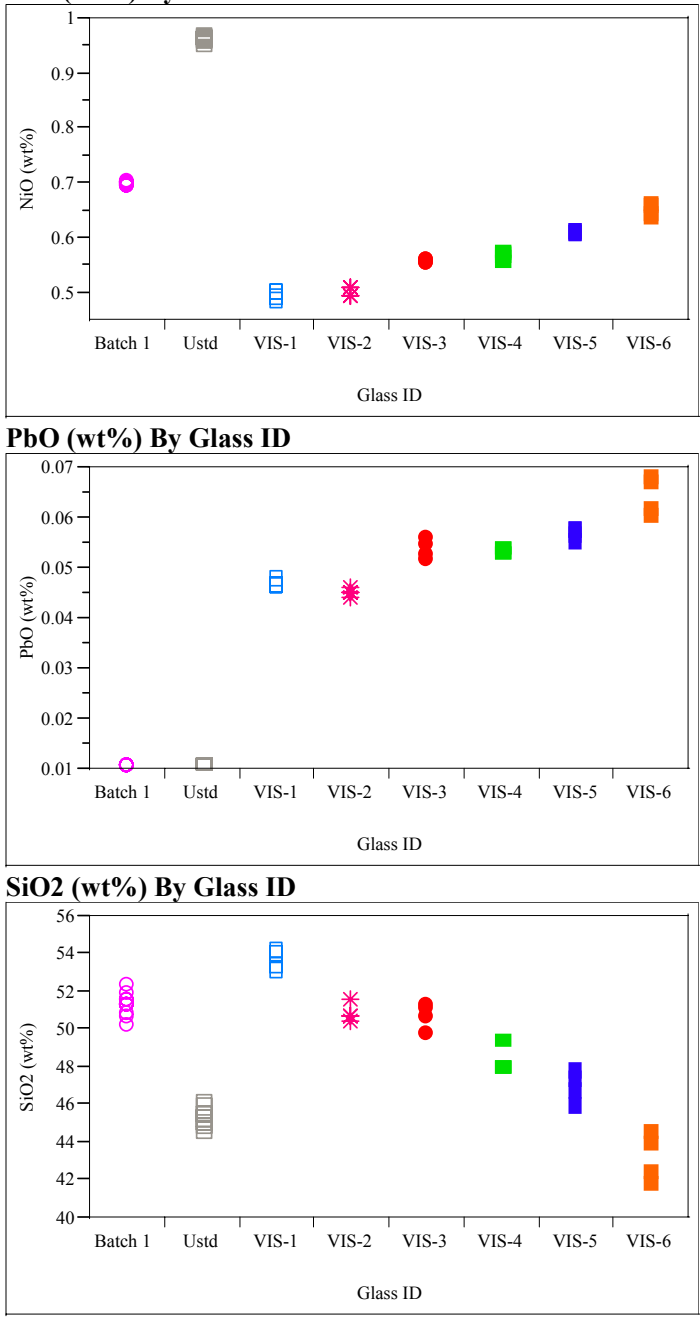

ThO2 (wt\%) By Glass ID

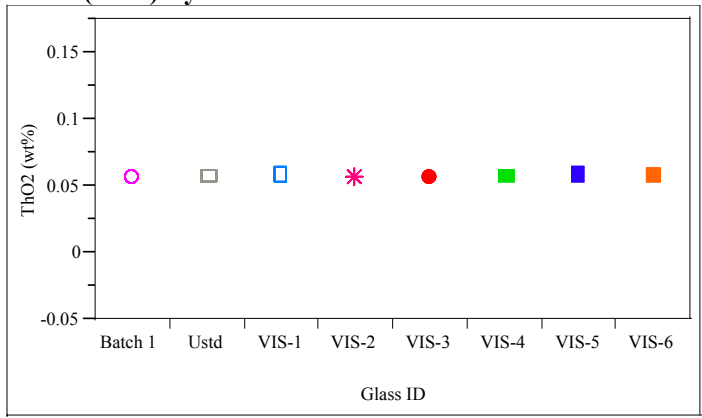




\section{Exhibit D5. Measured and Measured Bias-Corrected Oxide Weight Percents by Glass ID for the Glasses Prepared Using the LM Method}

TiO2 (wt\%) By Glass ID
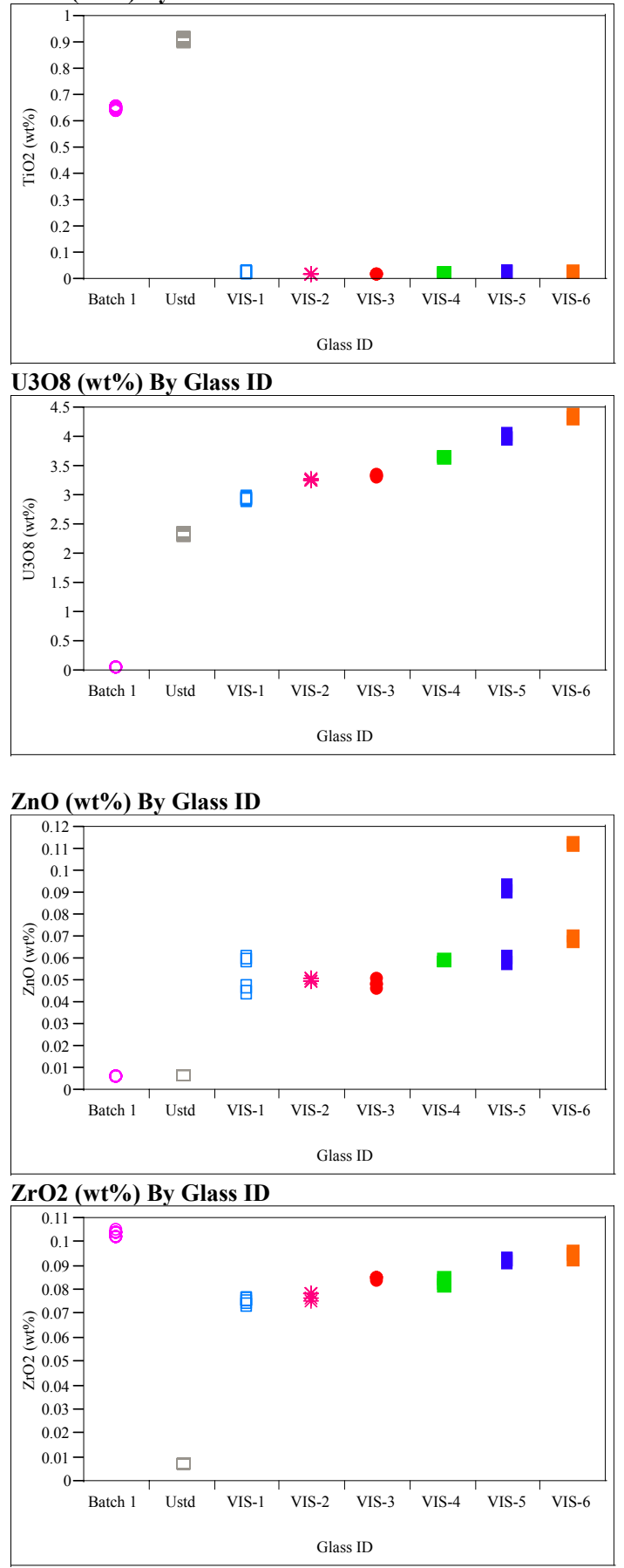

Al2O3 bc (wt\%) By Glass ID
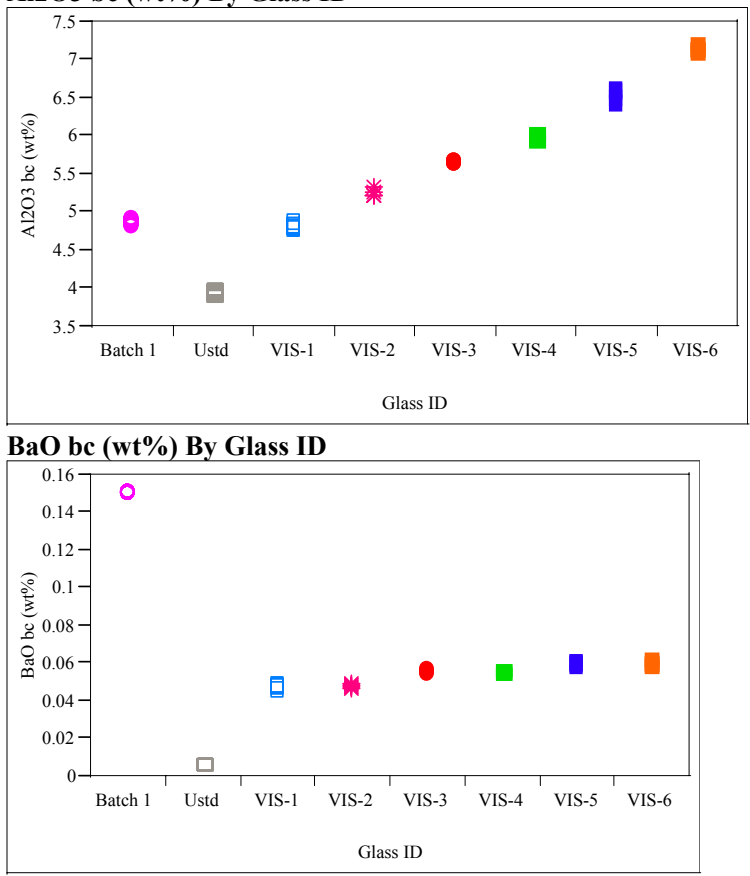

$\mathrm{CaO}$ bc (wt\%) By Glass ID
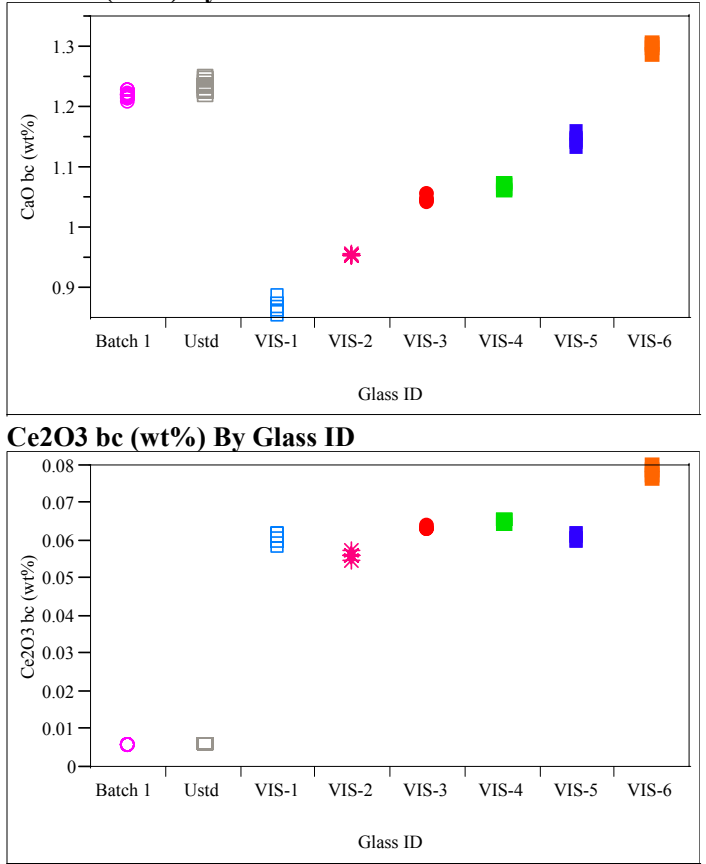


\section{Exhibit D5. Measured and Measured Bias-Corrected Oxide Weight Percents by Glass ID for the Glasses Prepared Using the LM Method}
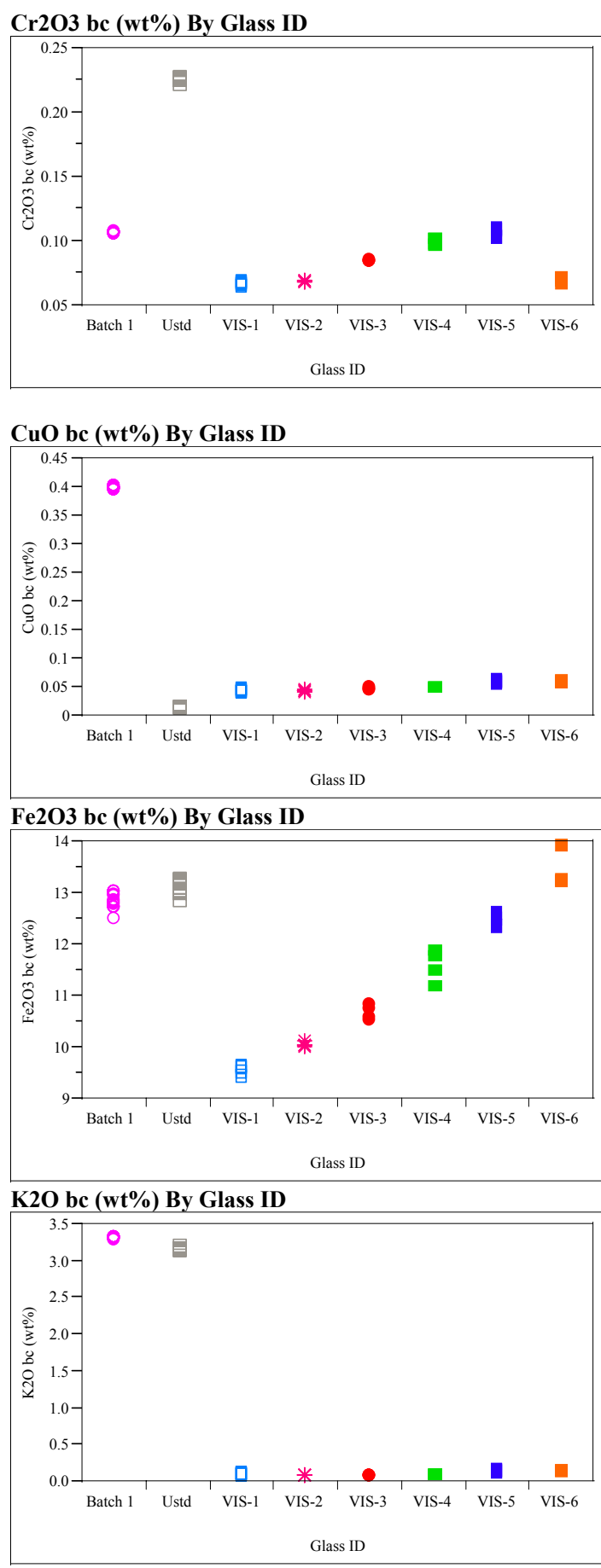
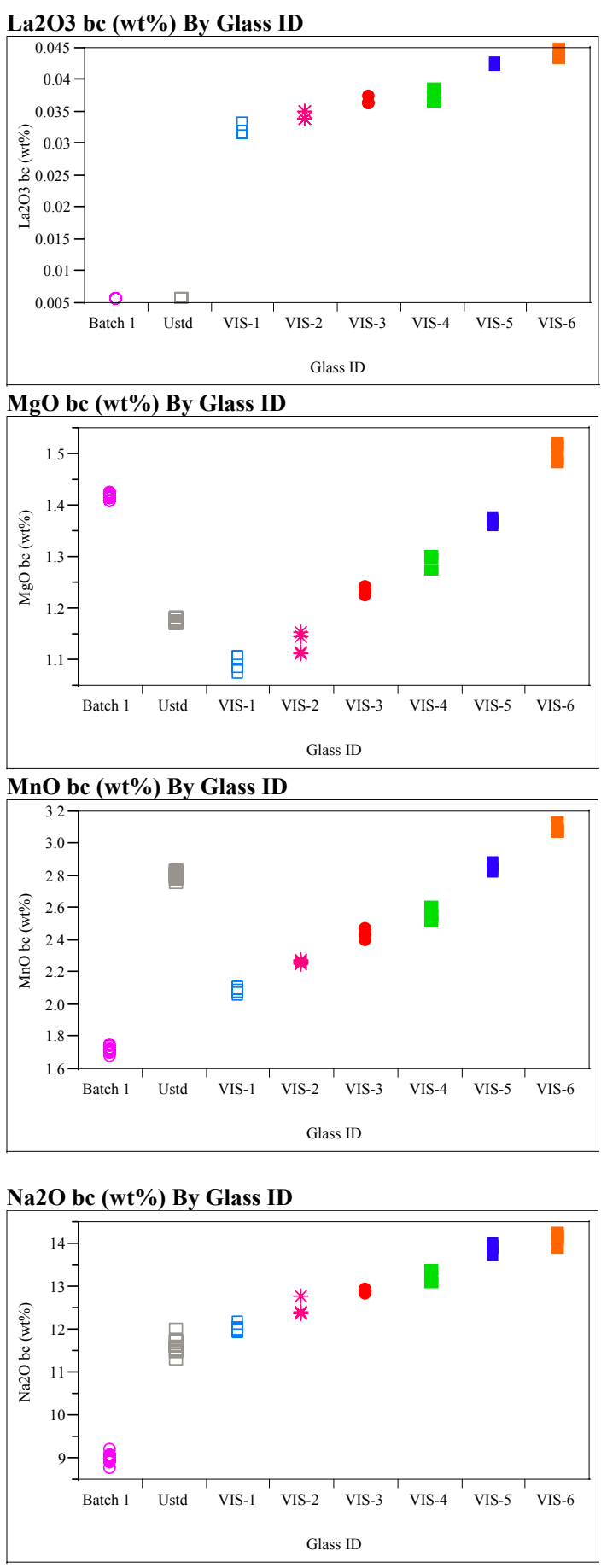


\section{Exhibit D5. Measured and Measured Bias-Corrected Oxide Weight Percents by Glass ID for the Glasses Prepared Using the LM Method}

NiO be (wt\%) By Glass ID

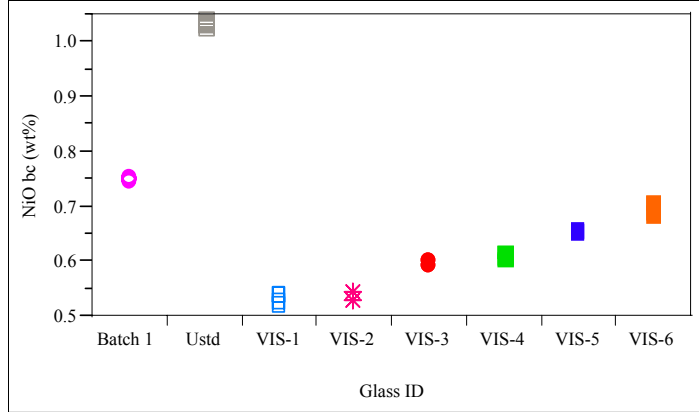

PbO bc (wt\%) By Glass ID

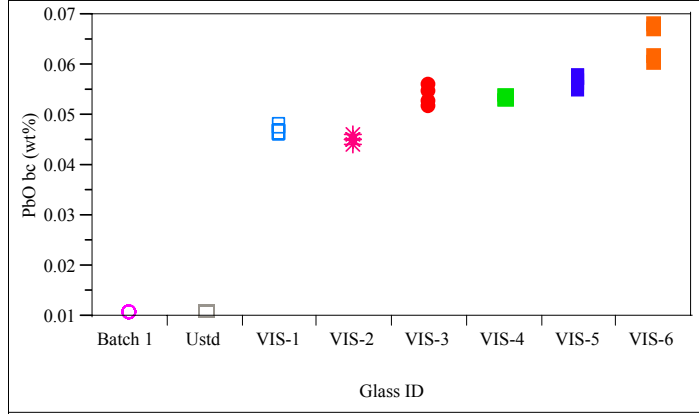

SiO2 be (wt\%) By Glass ID

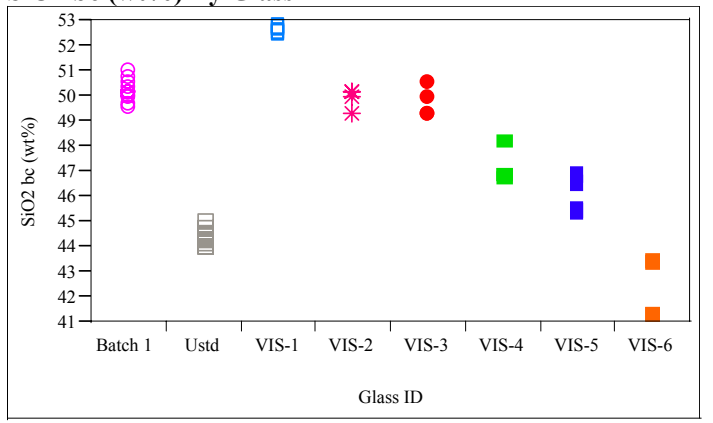

ThO2 bc (wt\%) By Glass ID

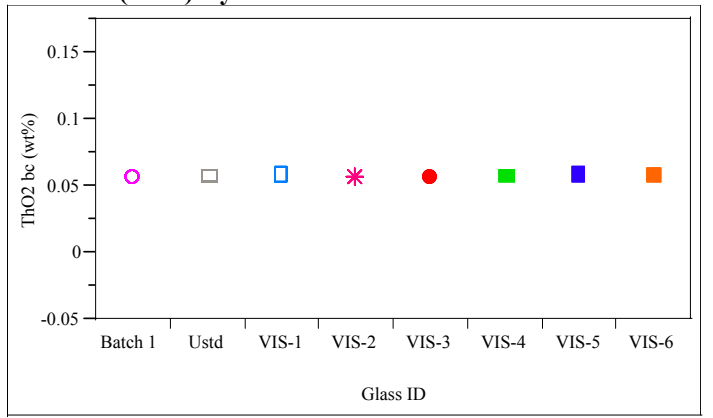

TiO2 be (wt\%) By Glass ID
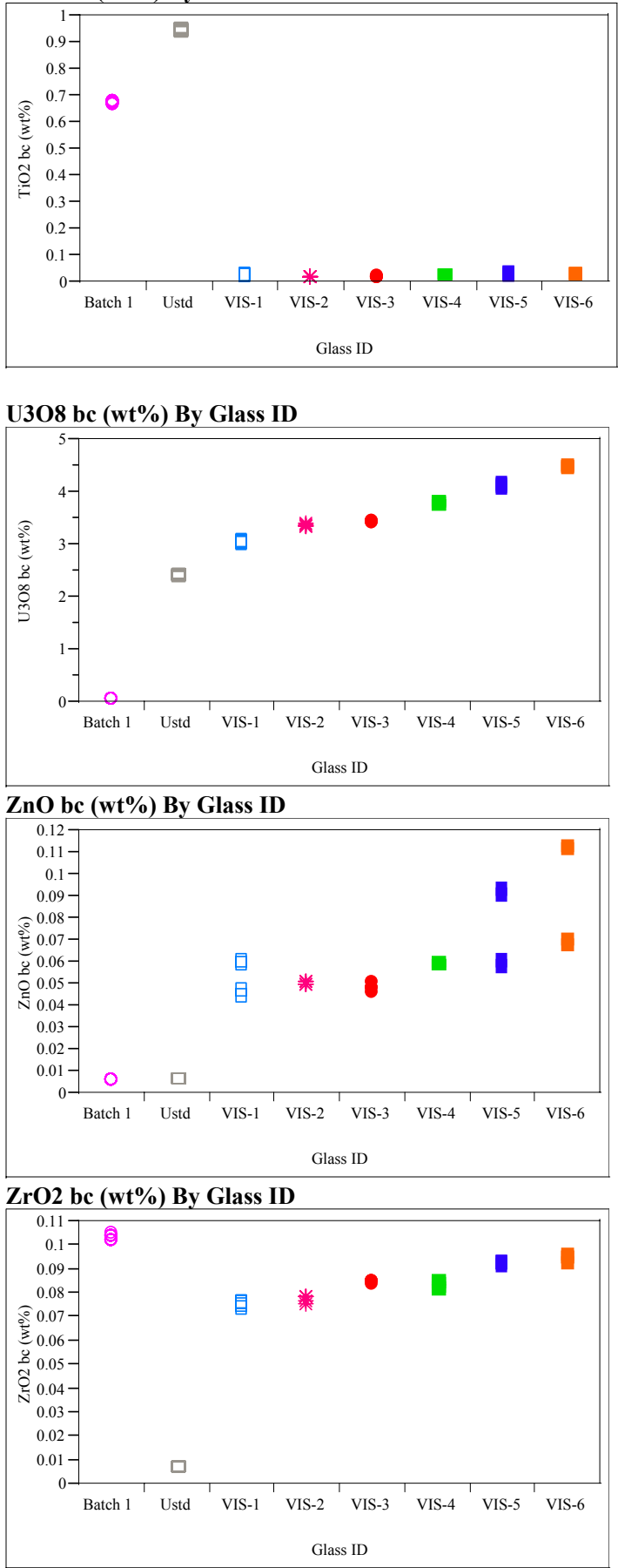


\section{Exhibit D6. Measured and Measured Bias-Corrected Oxide Weight Percents by} Glass \# for the Glasses Prepared Using the PF Method
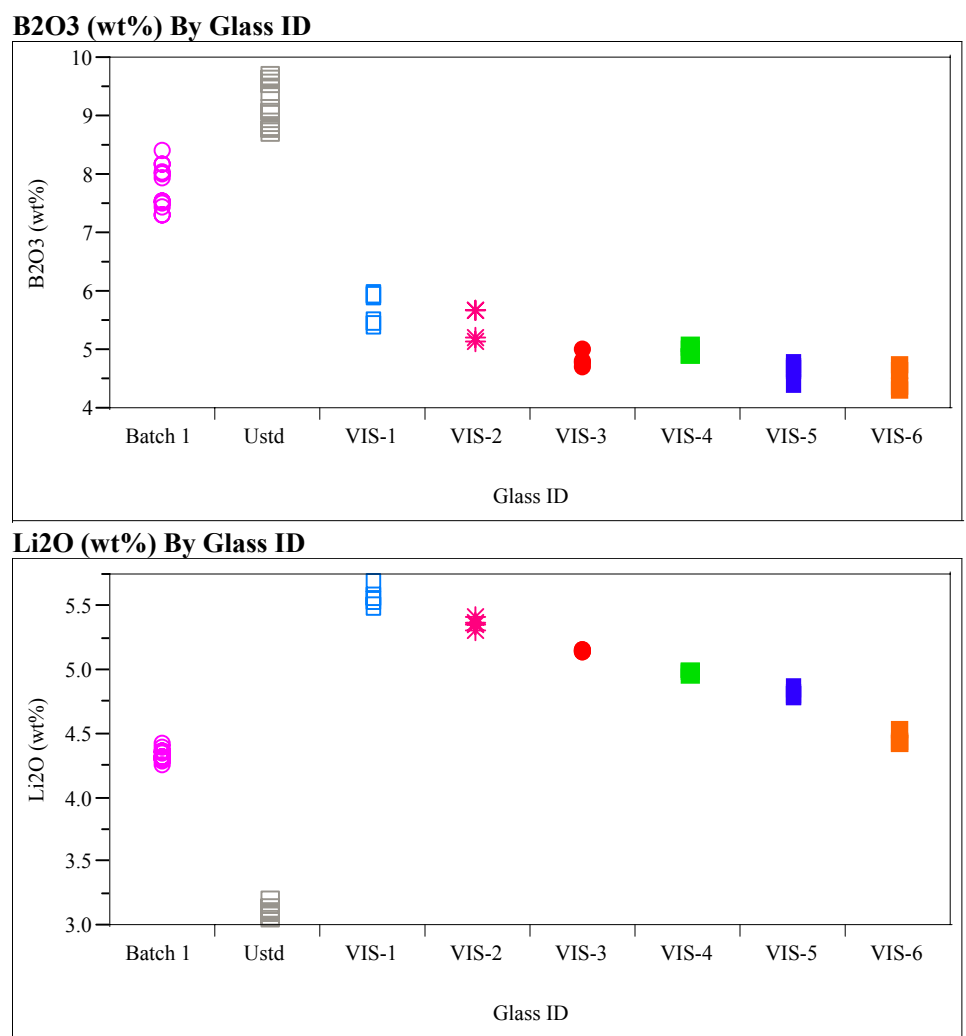

B2O3 be (wt\%) By Glass ID
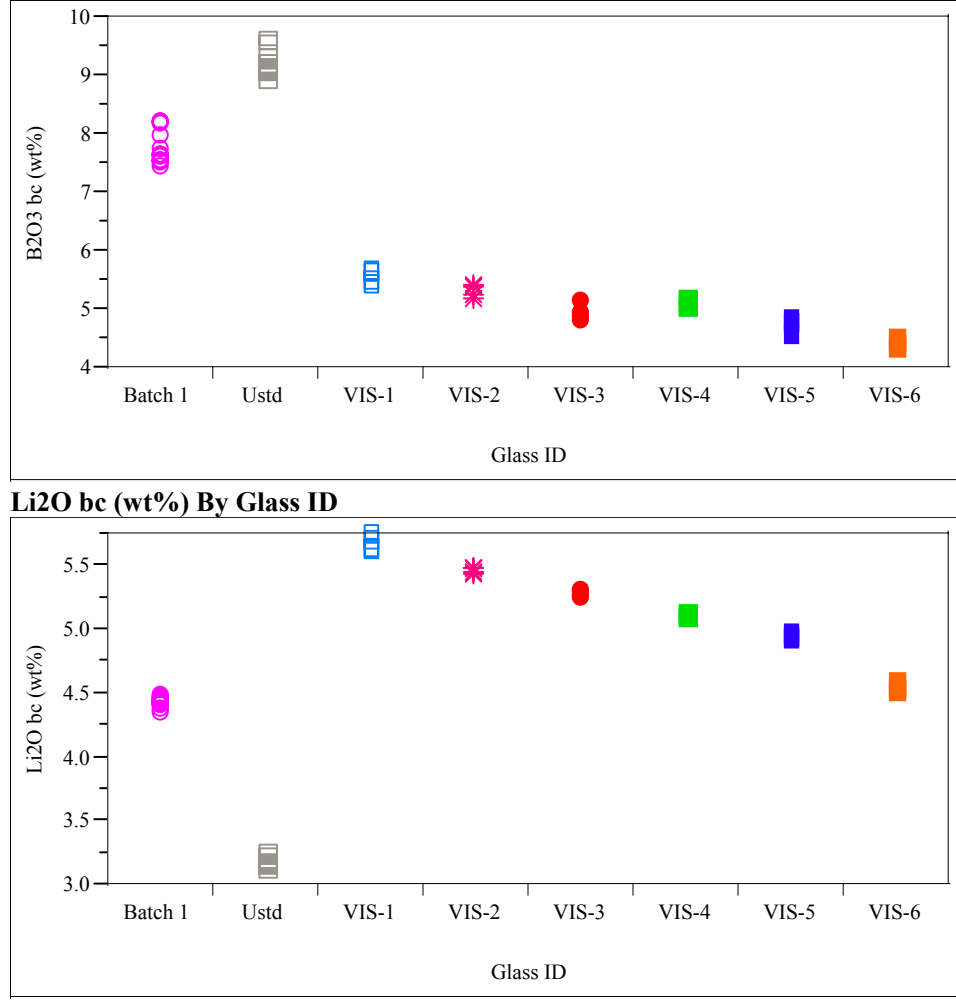


\section{Exhibit D7. Average Measured and Bias-Corrected (bc) Versus Targeted} Compositions by Glass ID by Oxide
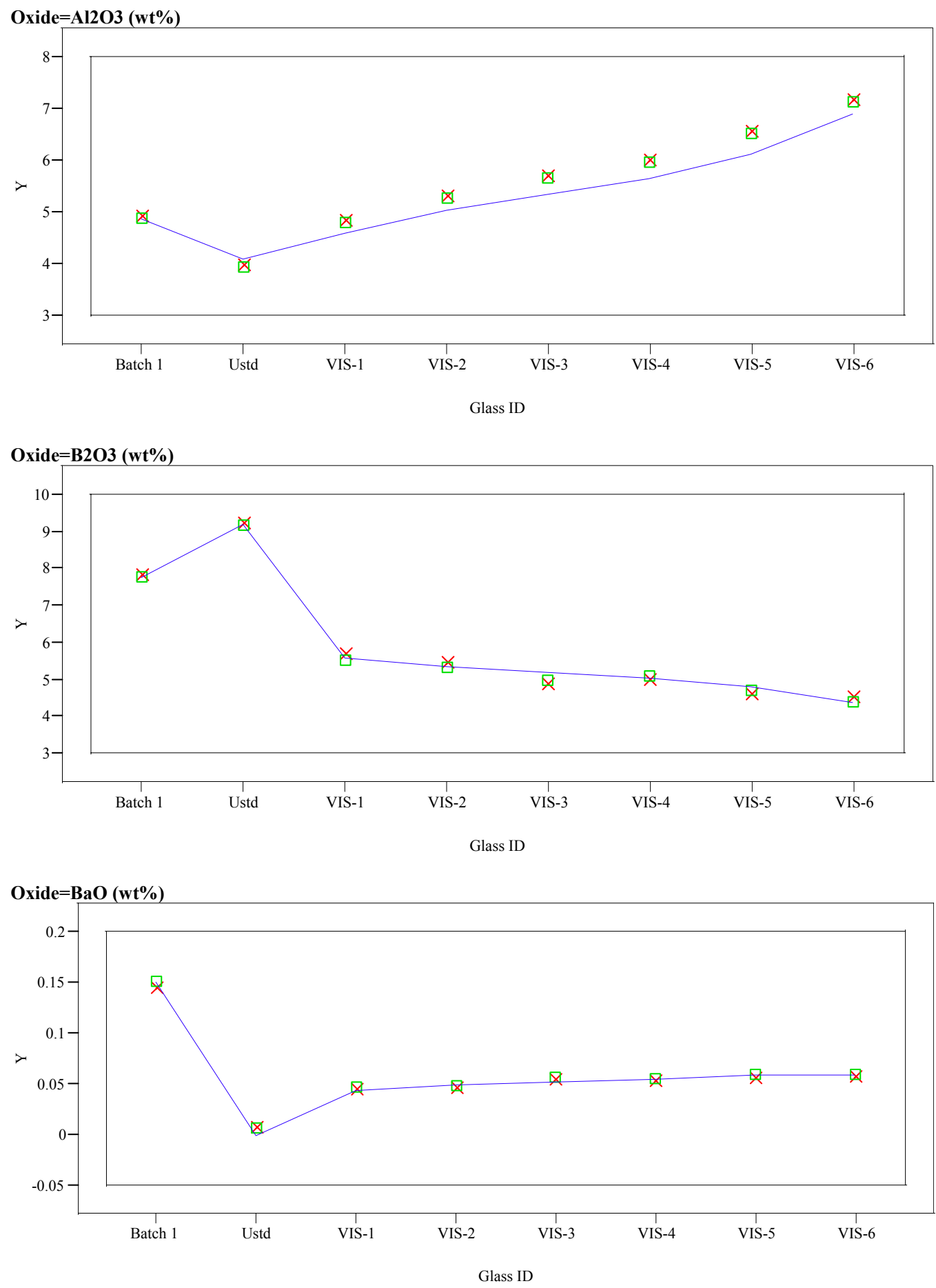

Y $\times$ Measured $\square$ Measured bc - Targeted 


\section{Exhibit D7. Average Measured and Bias-Corrected (bc) Versus Targeted Compositions by Glass ID by Oxide}
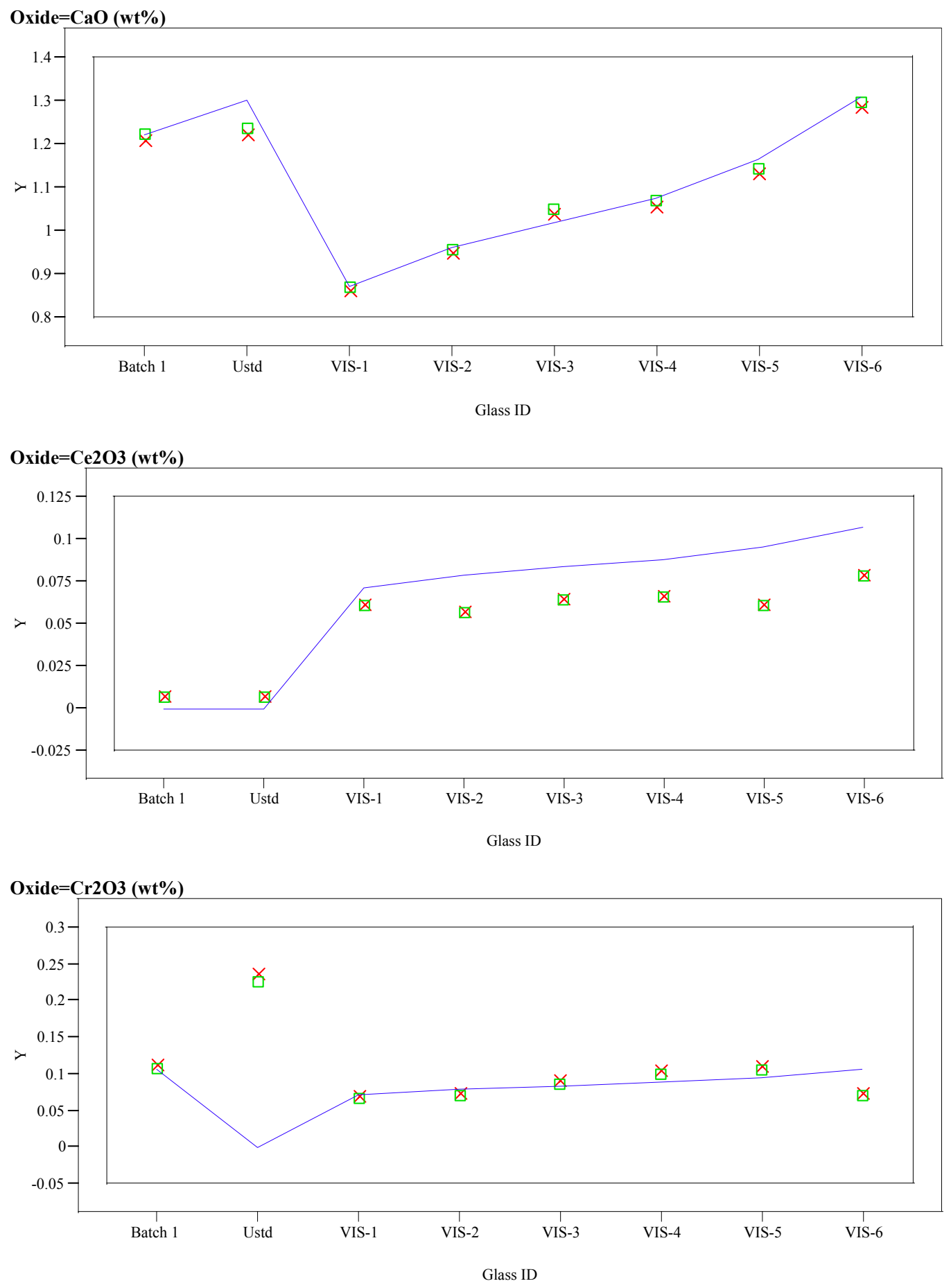

Y $\times$ Measured $\square$ Measured bc - Targeted 


\section{Exhibit D7. Average Measured and Bias-Corrected (bc) Versus Targeted} Compositions by Glass ID by Oxide
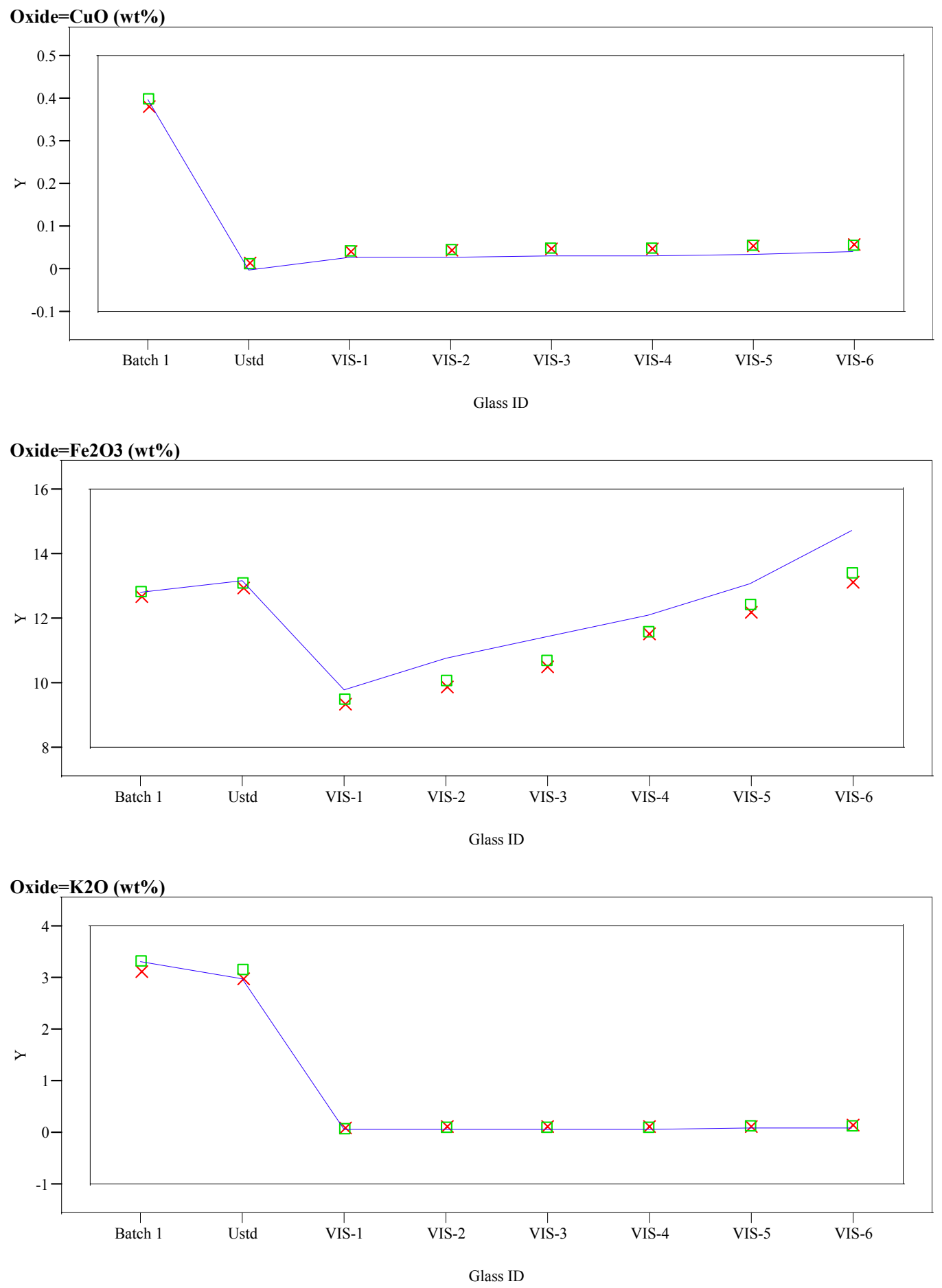

$\mathrm{Y} \times$ Measured $\square$ Measured bc - Targeted 


\section{Exhibit D7. Average Measured and Bias-Corrected (bc) Versus Targeted Compositions by Glass ID by Oxide}
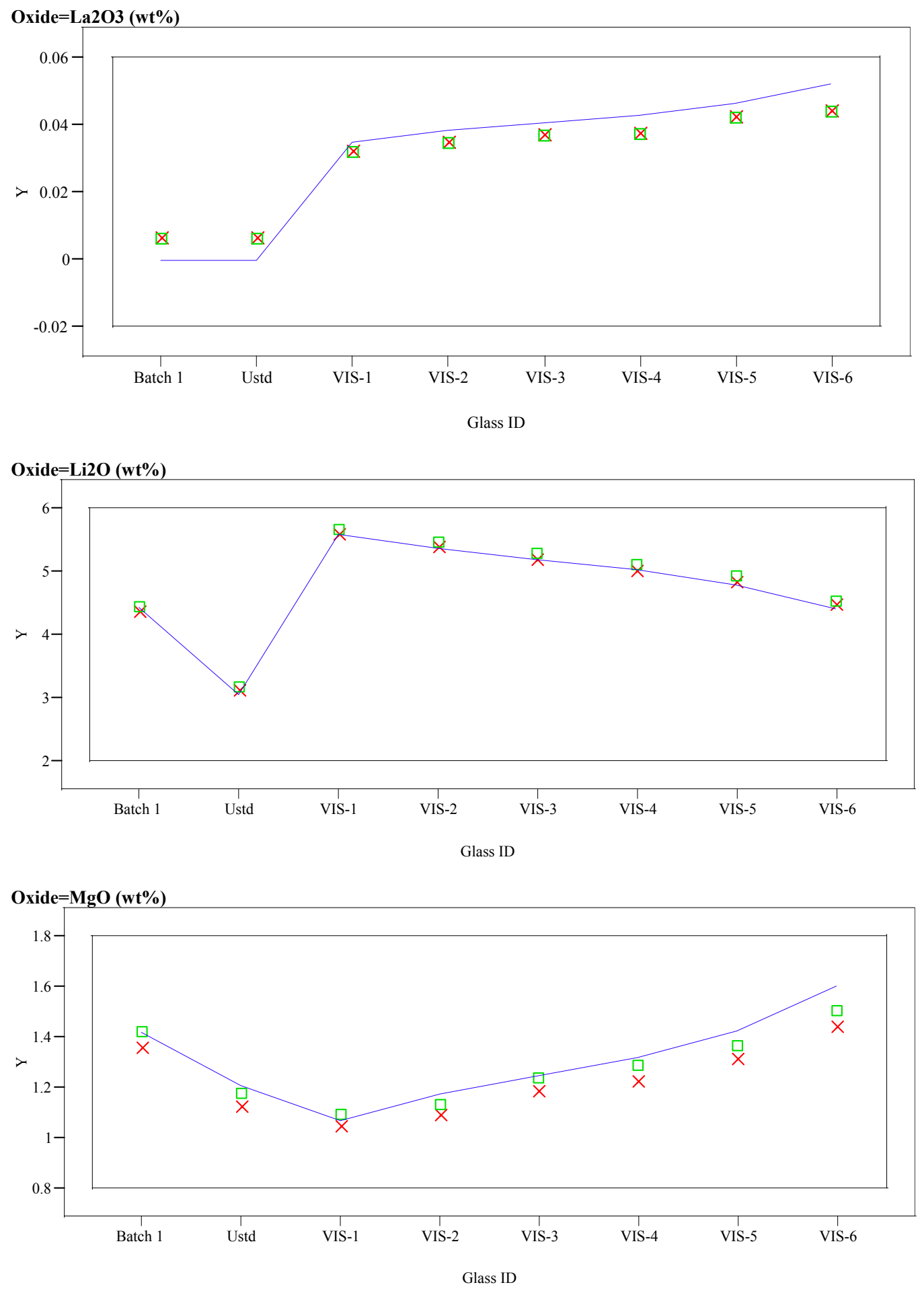

$\mathrm{Y} \times$ Measured $\square$ Measured bc - Targeted 


\section{Exhibit D7. Average Measured and Bias-Corrected (bc) Versus Targeted Compositions by Glass ID by Oxide}
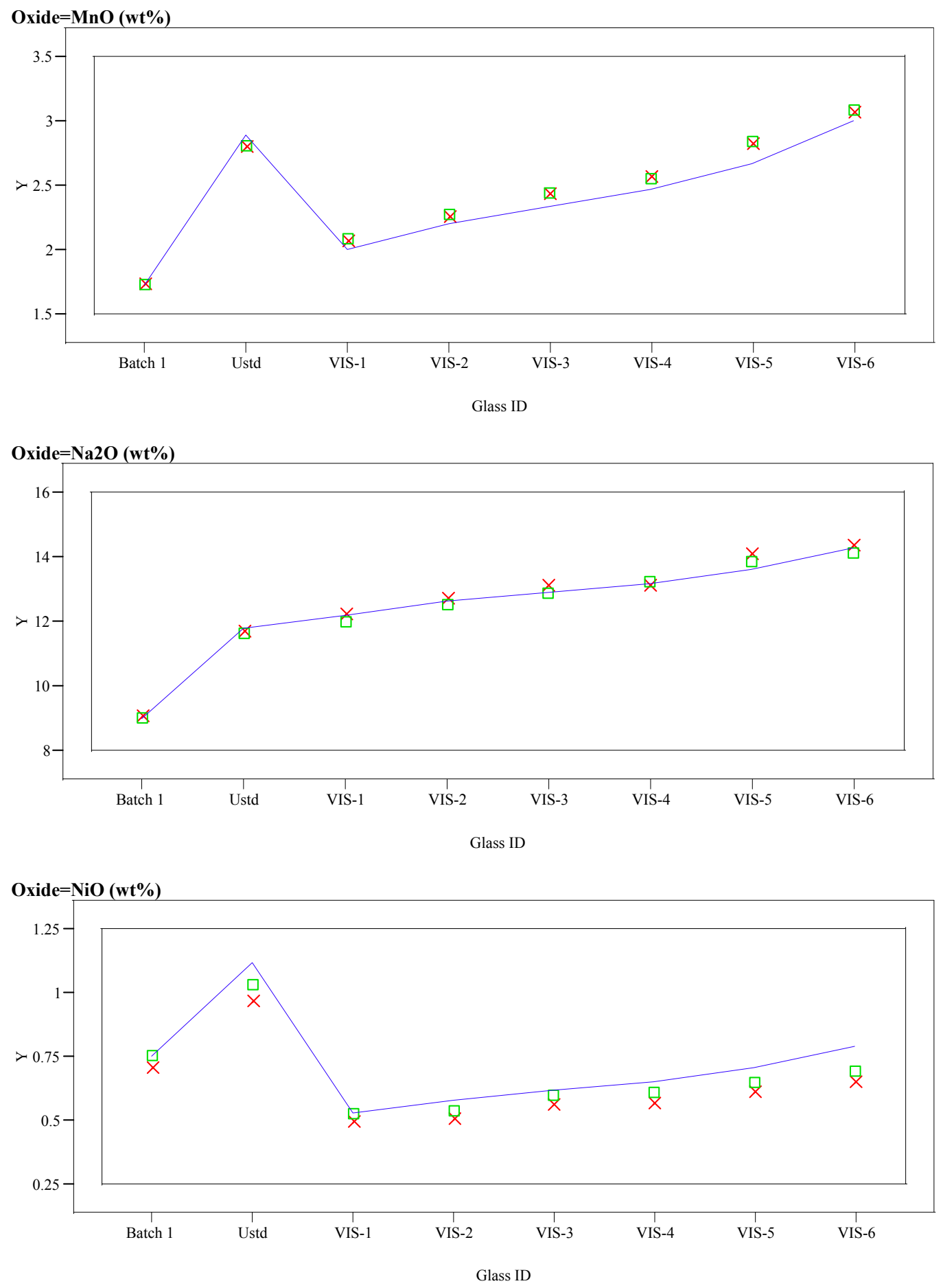

Y $\times$ Measured $\square$ Measured bc $\diamond$ Targeted 


\section{Exhibit D7. Average Measured and Bias-Corrected (bc) Versus Targeted Compositions by Glass ID by Oxide}
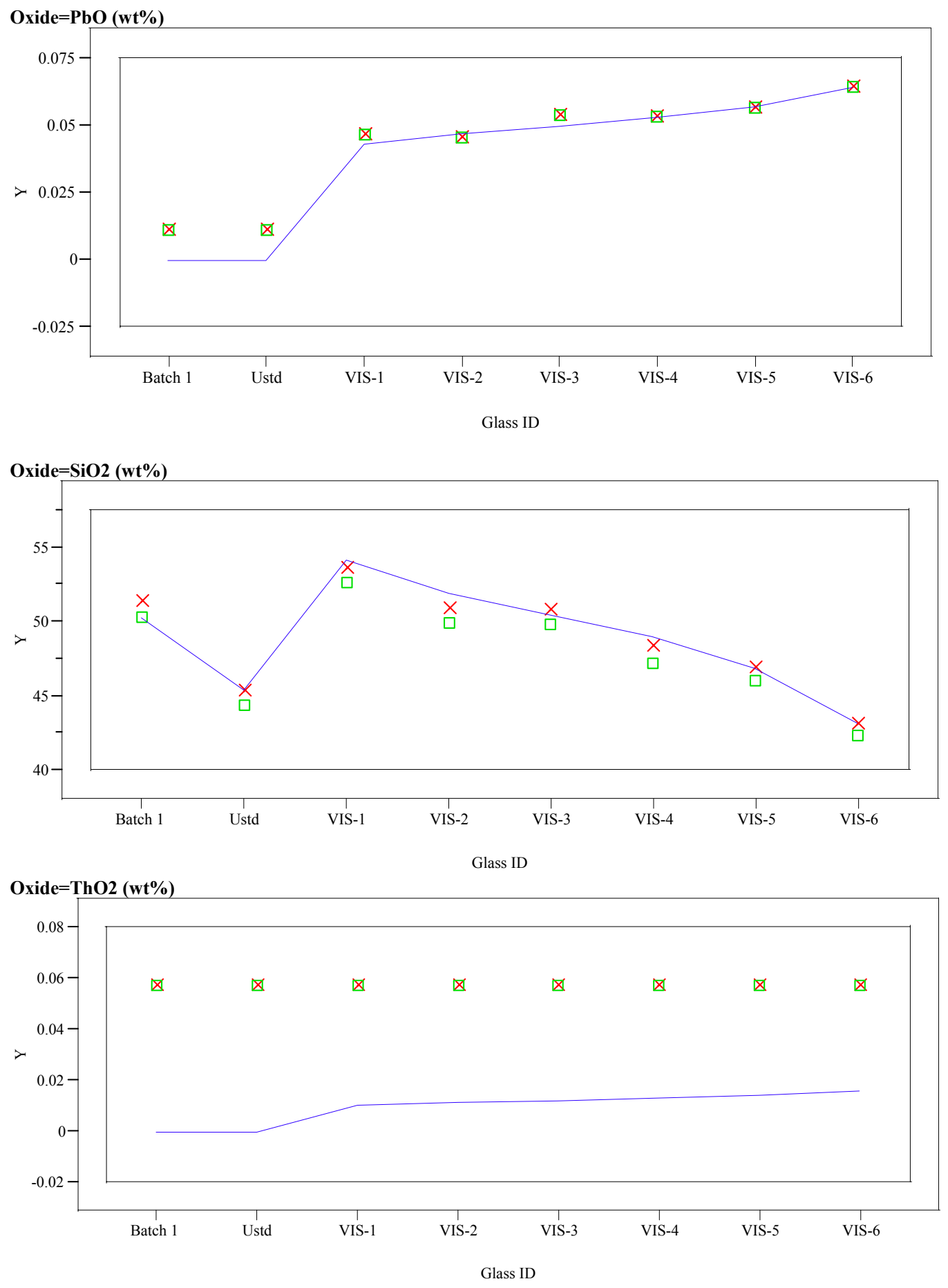

$\mathrm{Y} \times$ Measured $\square$ Measured bc- Targeted 


\section{Exhibit D7. Average Measured and Bias-Corrected (bc) Versus Targeted Compositions by Glass ID by Oxide}
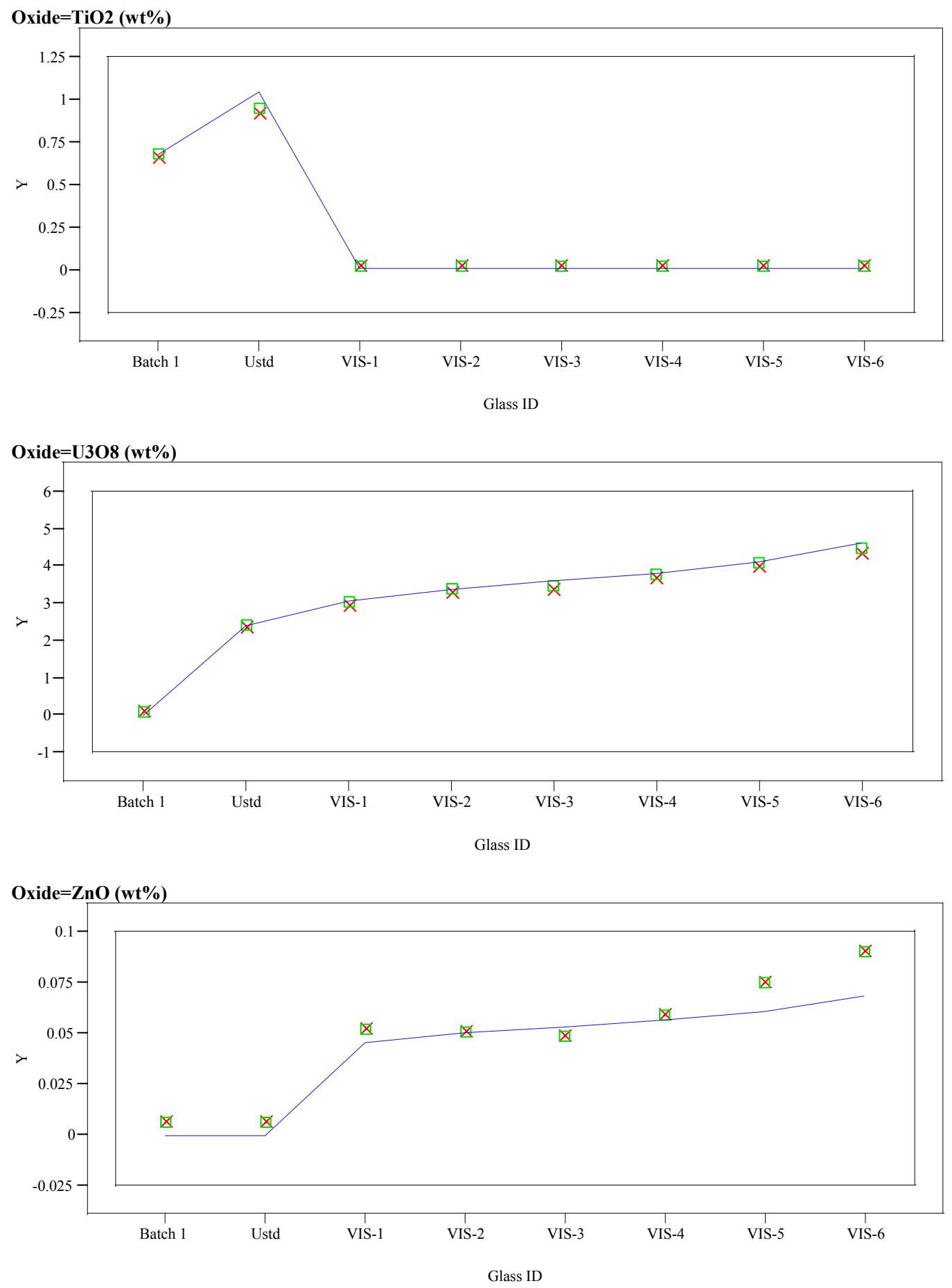

$\mathrm{Y} \times$ Measured $\square$ Measured bc - Targeted 


\section{Exhibit D7. Average Measured and Bias-Corrected (bc) Versus Targeted} Compositions by Glass ID by Oxide
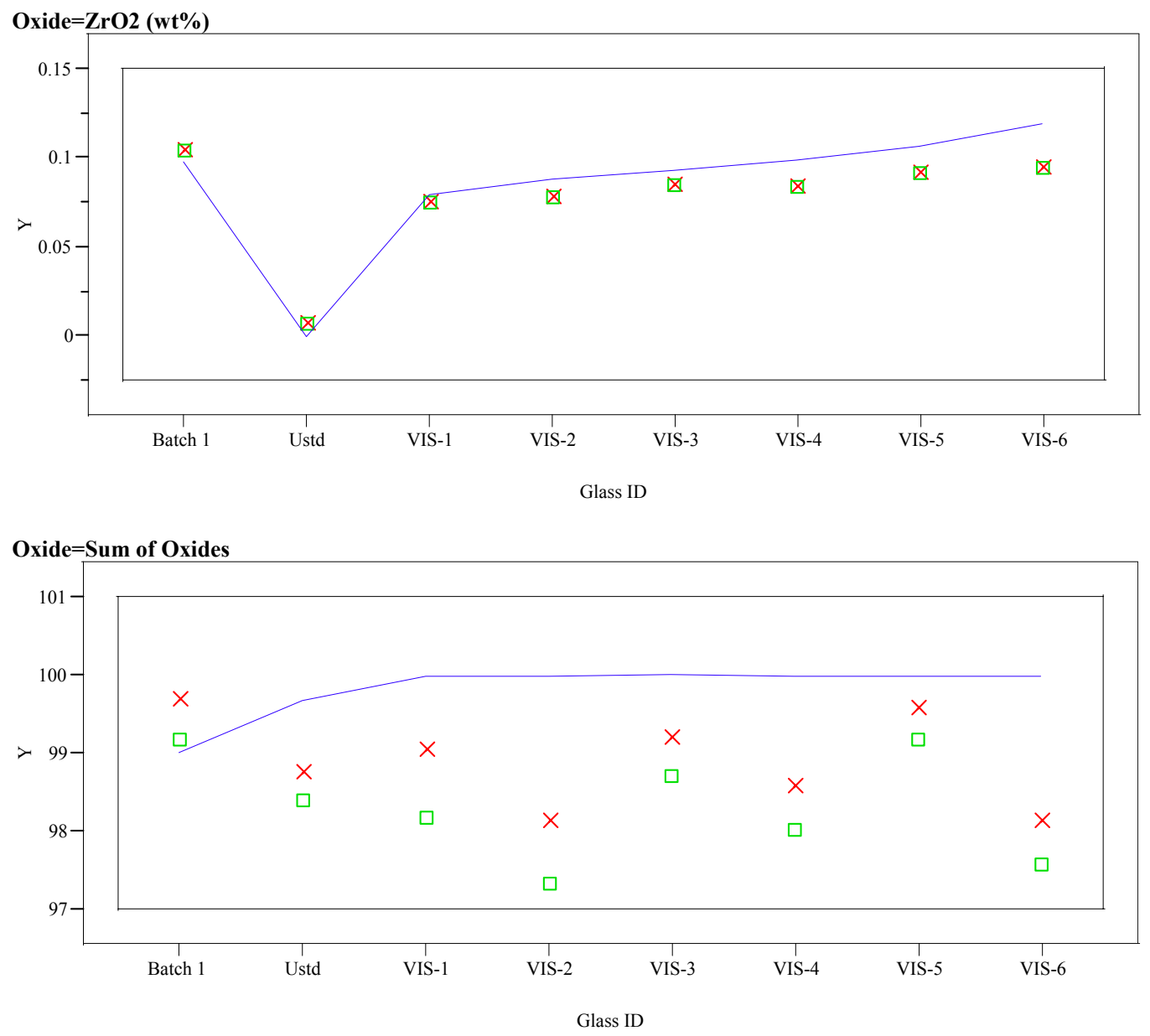

$\mathrm{Y} \times$ Measured $\square$ Measured bc - Targeted 
WSRC-TR-2004-00429

Revision 0

This page intentionally left blank. 


\section{APPENDIX E}

\section{Fulcher Fits of the Viscosity Measurements for the DWPF Start-Up Frit and the VIS Glasses}




\section{Exhibit E1. Fulcher Fit for DWPF Startup Frit from 5-04-04}

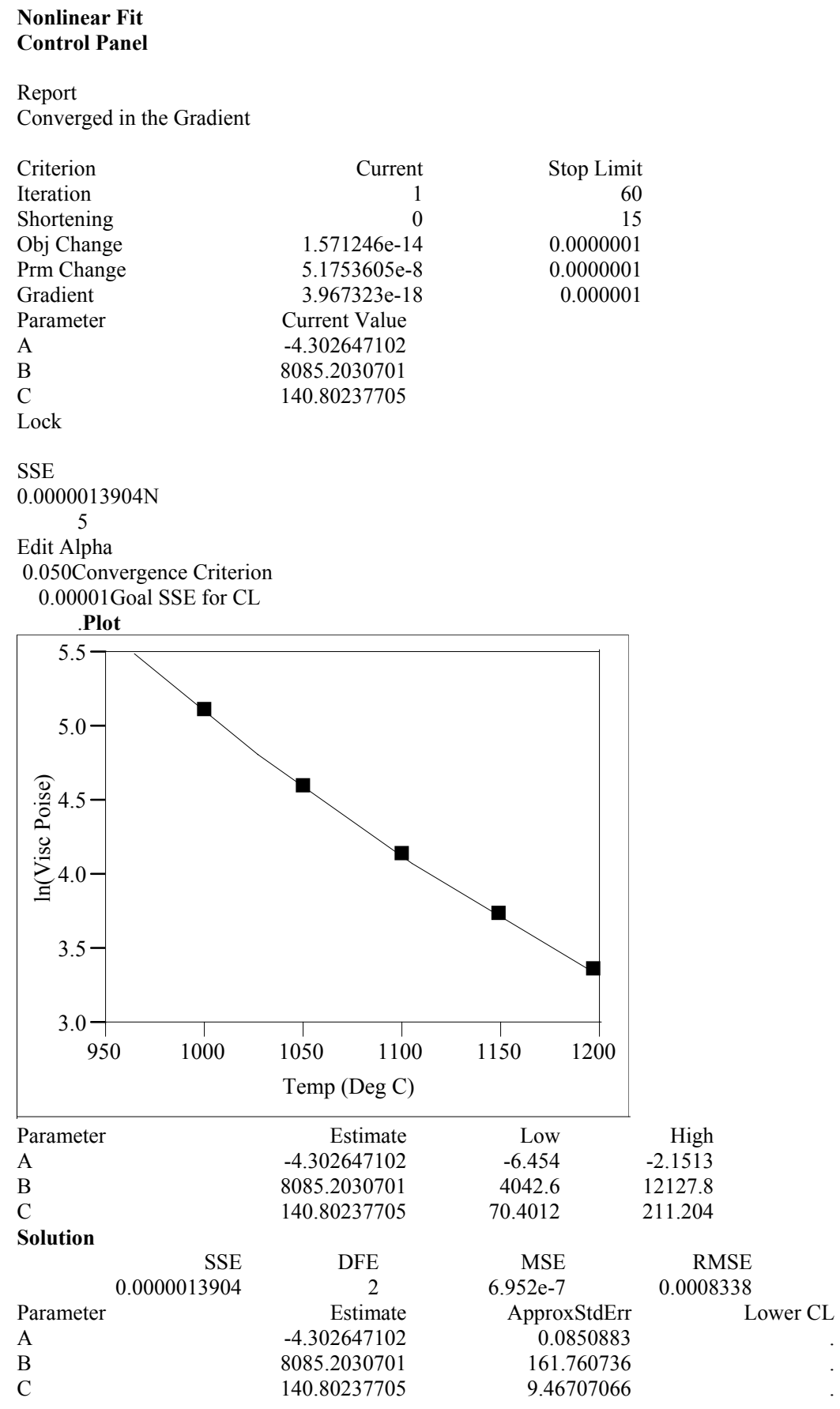

$\begin{array}{rr}\text { Current } & \text { Stop Limit } \\ 1 & 60 \\ 0 & 15 \\ 1.571246 \mathrm{e}-14 & 0.0000001 \\ 5.1753605 \mathrm{e}-8 & 0.0000001 \\ 3.967323 \mathrm{e}-18 & 0.000001\end{array}$




\section{Exhibit E2. Fulcher Fit for DWPF Startup Frit from 5-18-04}

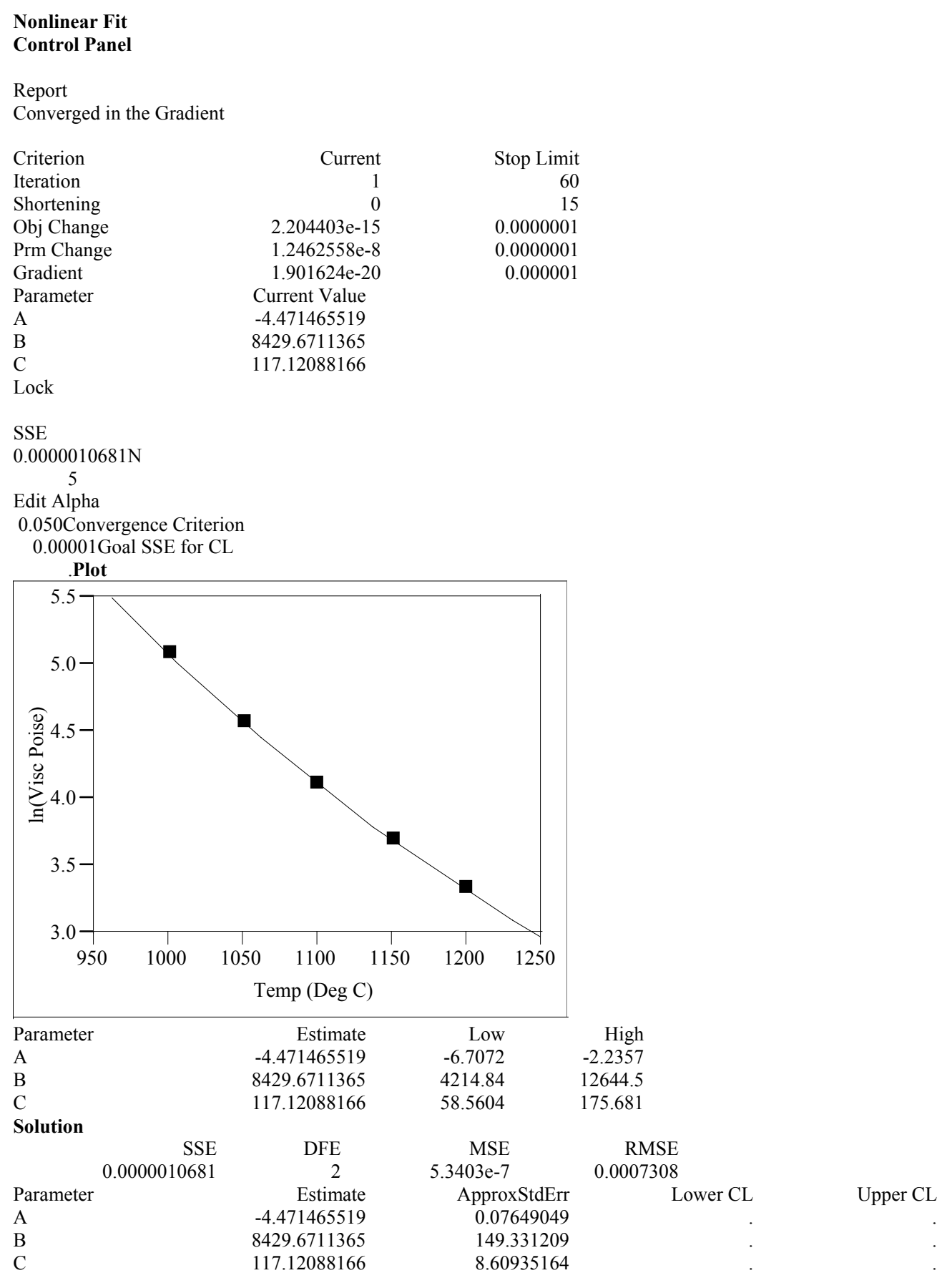


Exhibit E3. Fulcher Fit for DWPF Startup Frit from 6-7-04

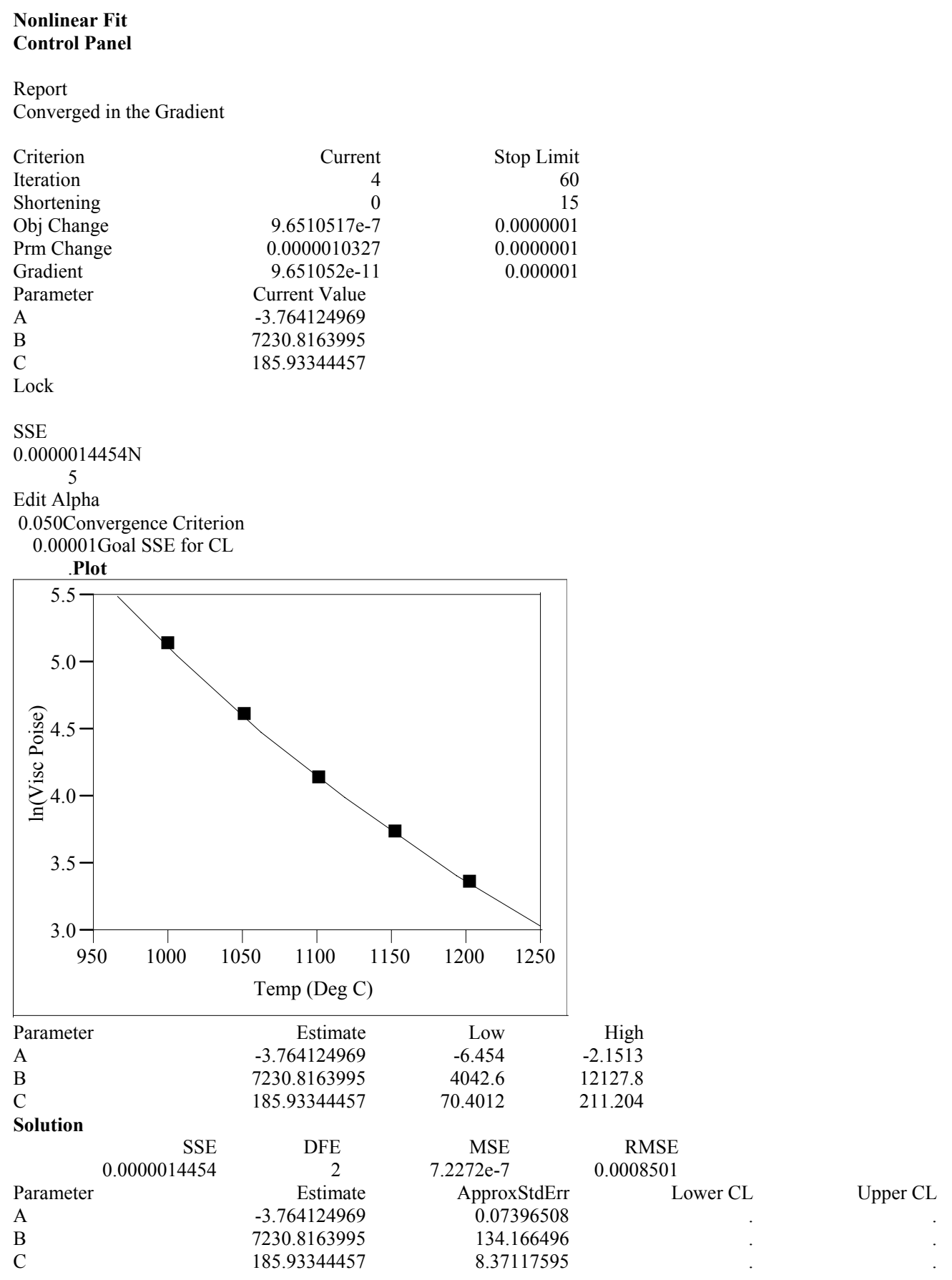


Exhibit E4. Fulcher Fit for DWPF Startup Frit from 6-8-04

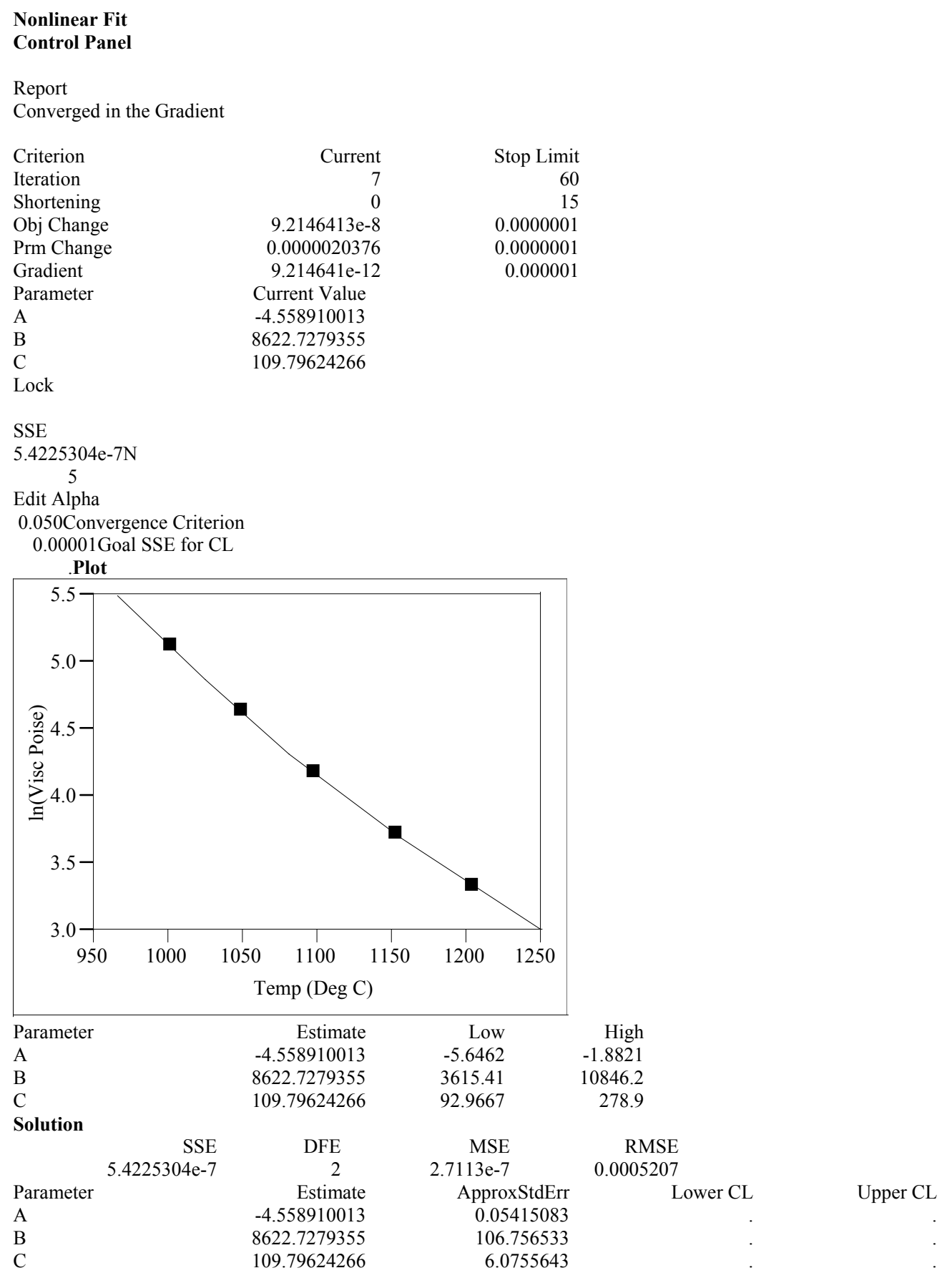




\section{Exhibit E5. Fulcher Fit for VIS-01}

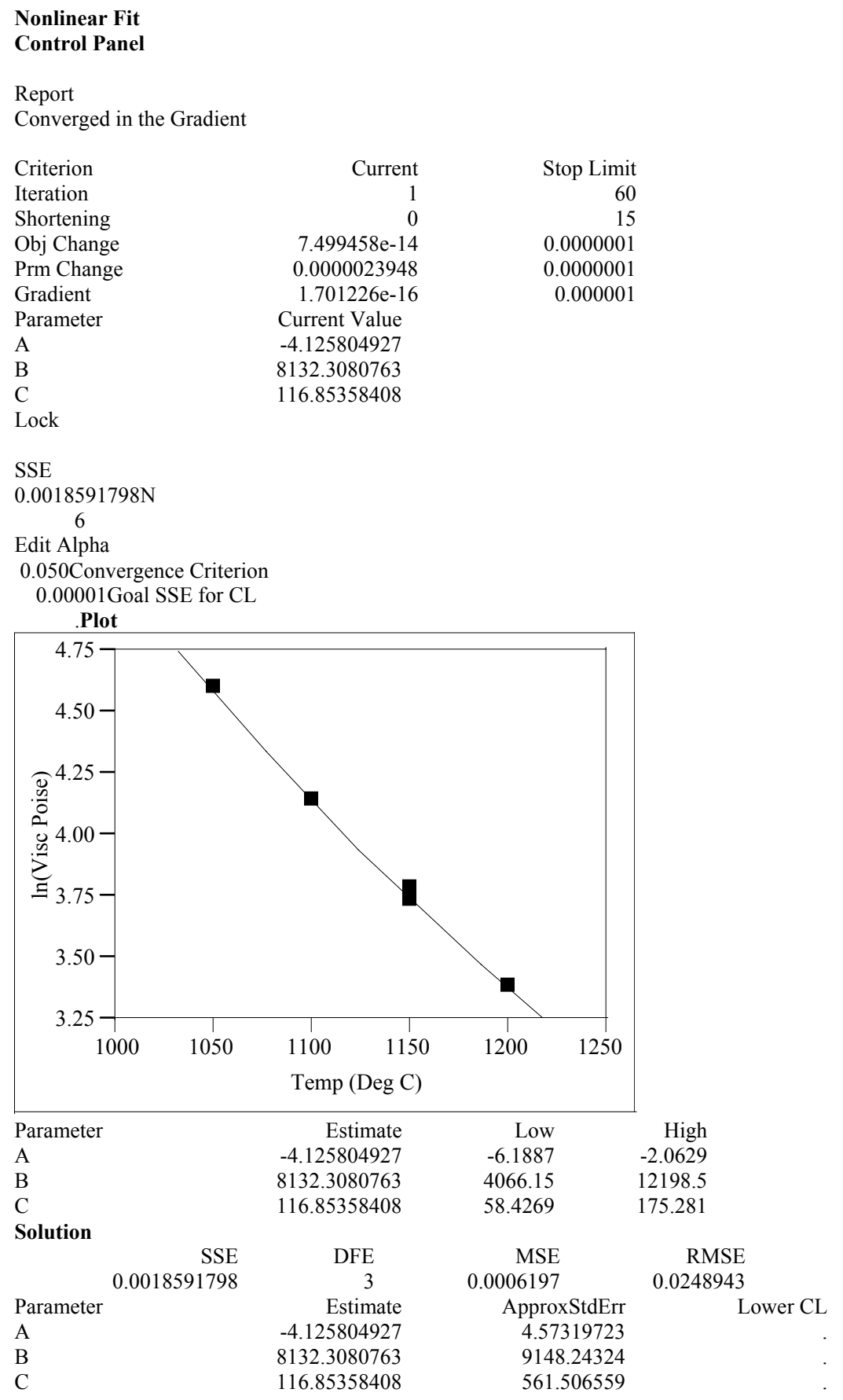

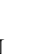


Exhibit E6. Fulcher Fit for VIS-02

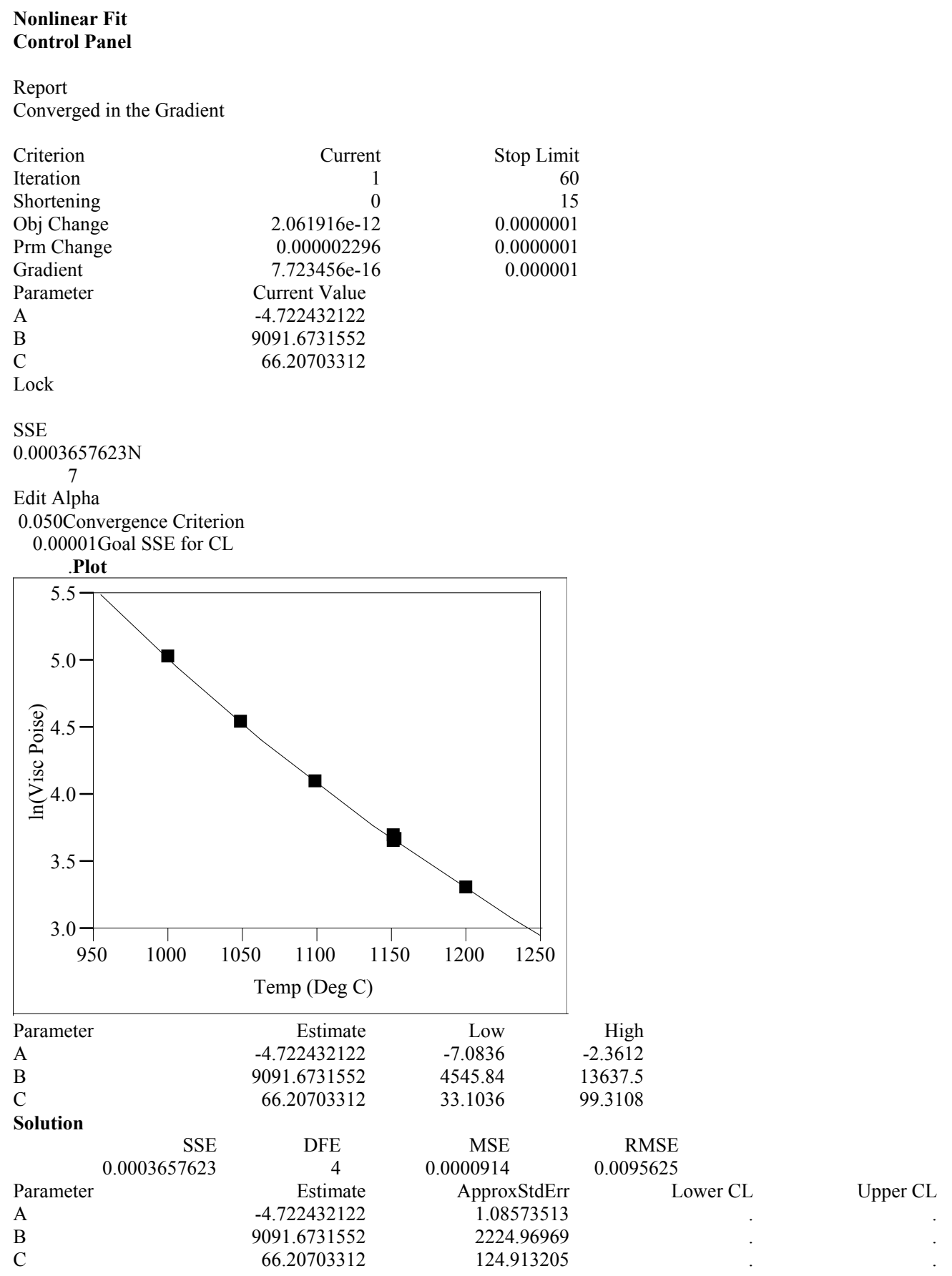


Exhibit E7. Fulcher Fit for VIS-03

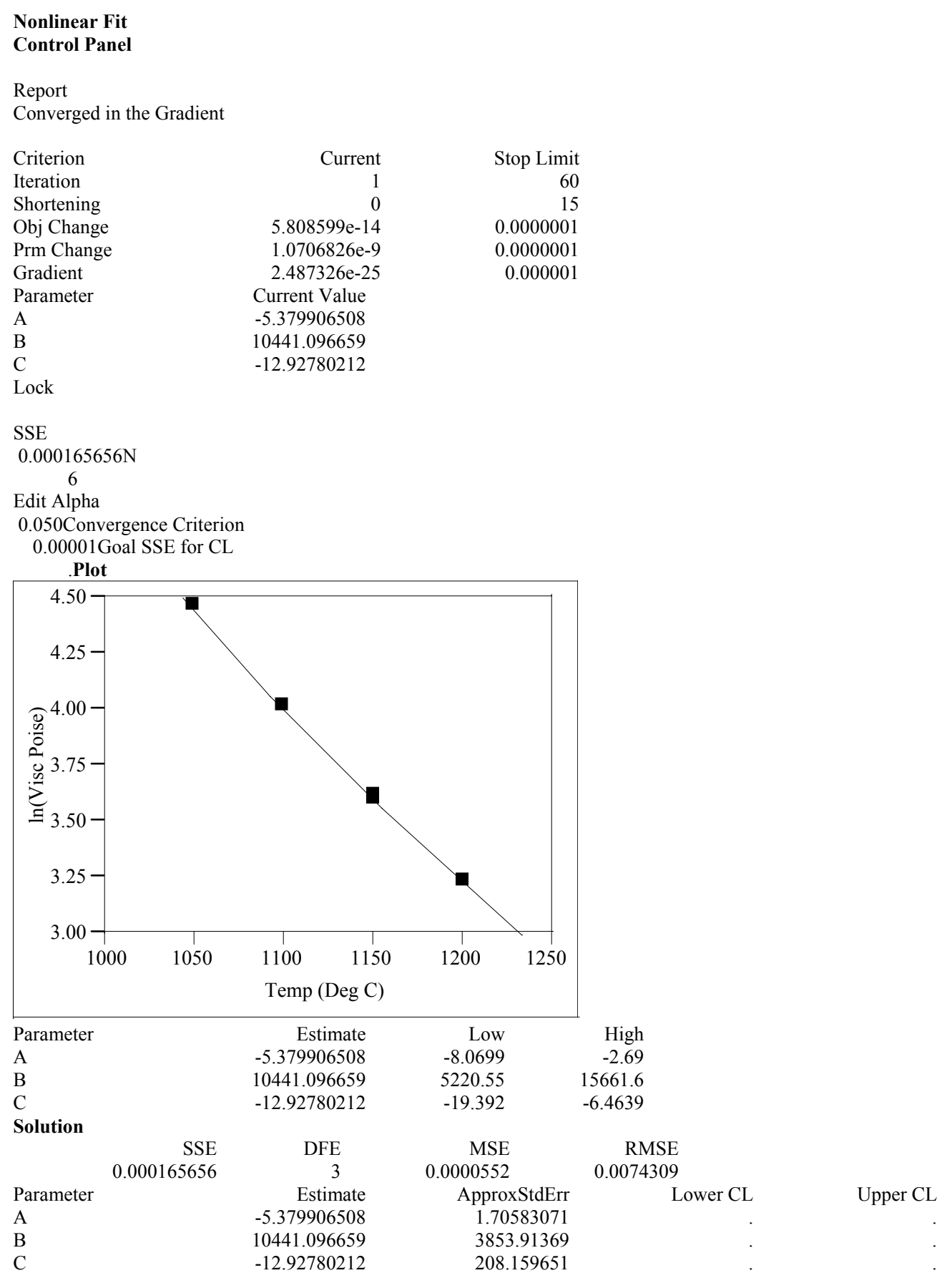


Exhibit E8. Fulcher Fit for VIS-04

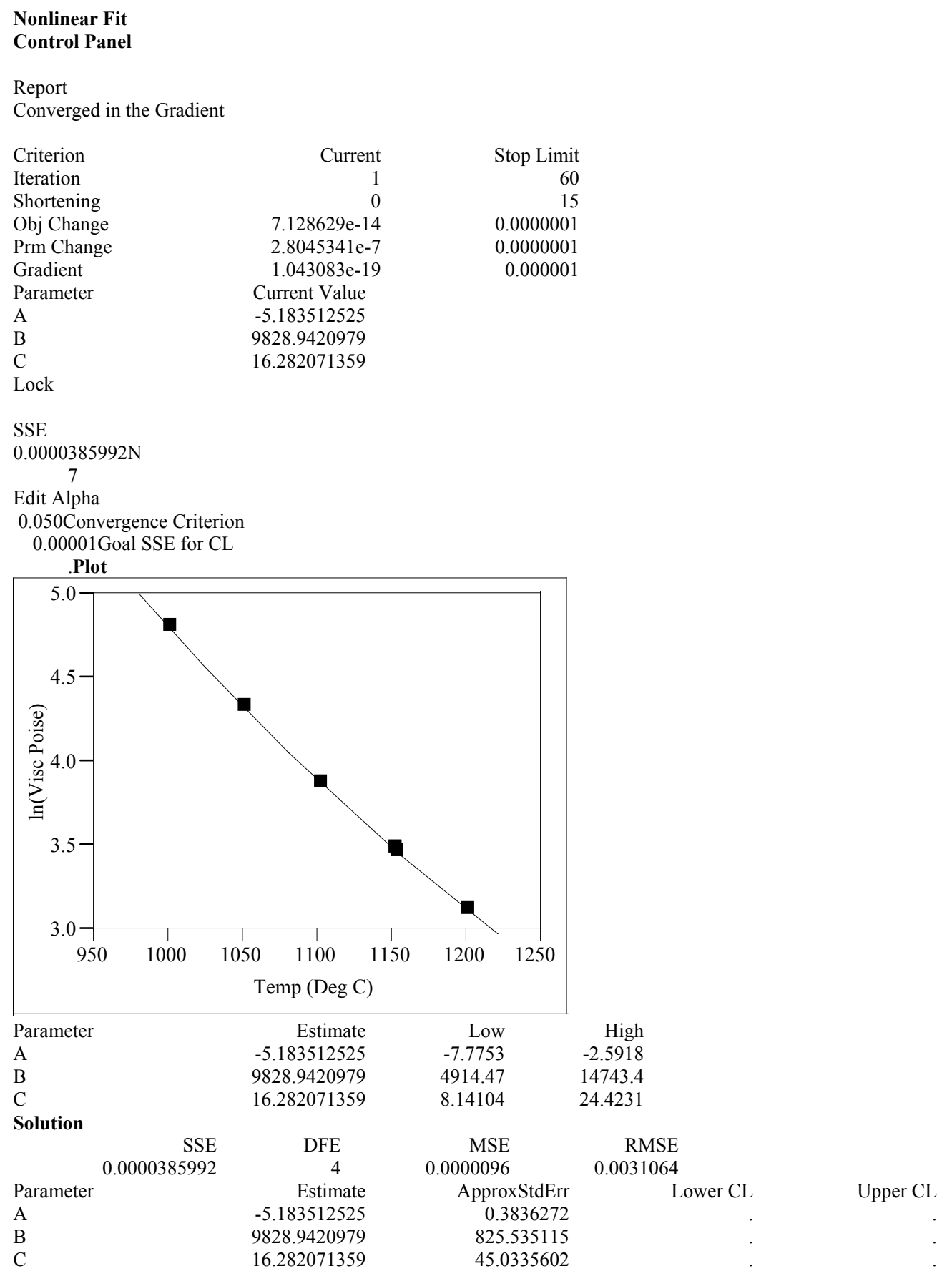


WSRC-TR-2004-00429

Revision 0

Exhibit E9. Fulcher Fit for VIS-05

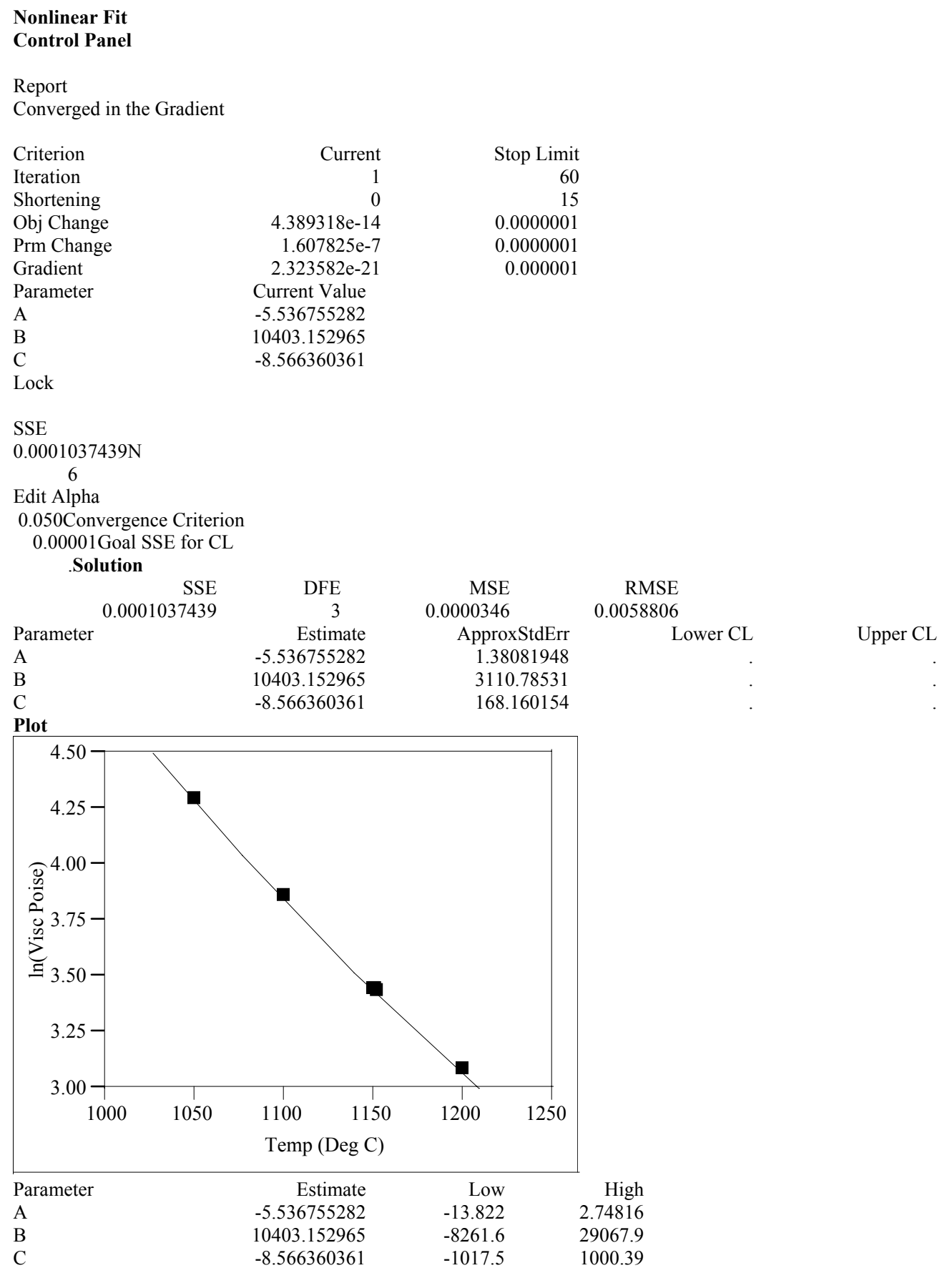




\section{Exhibit E10. Fulcher Fit for VIS-06}

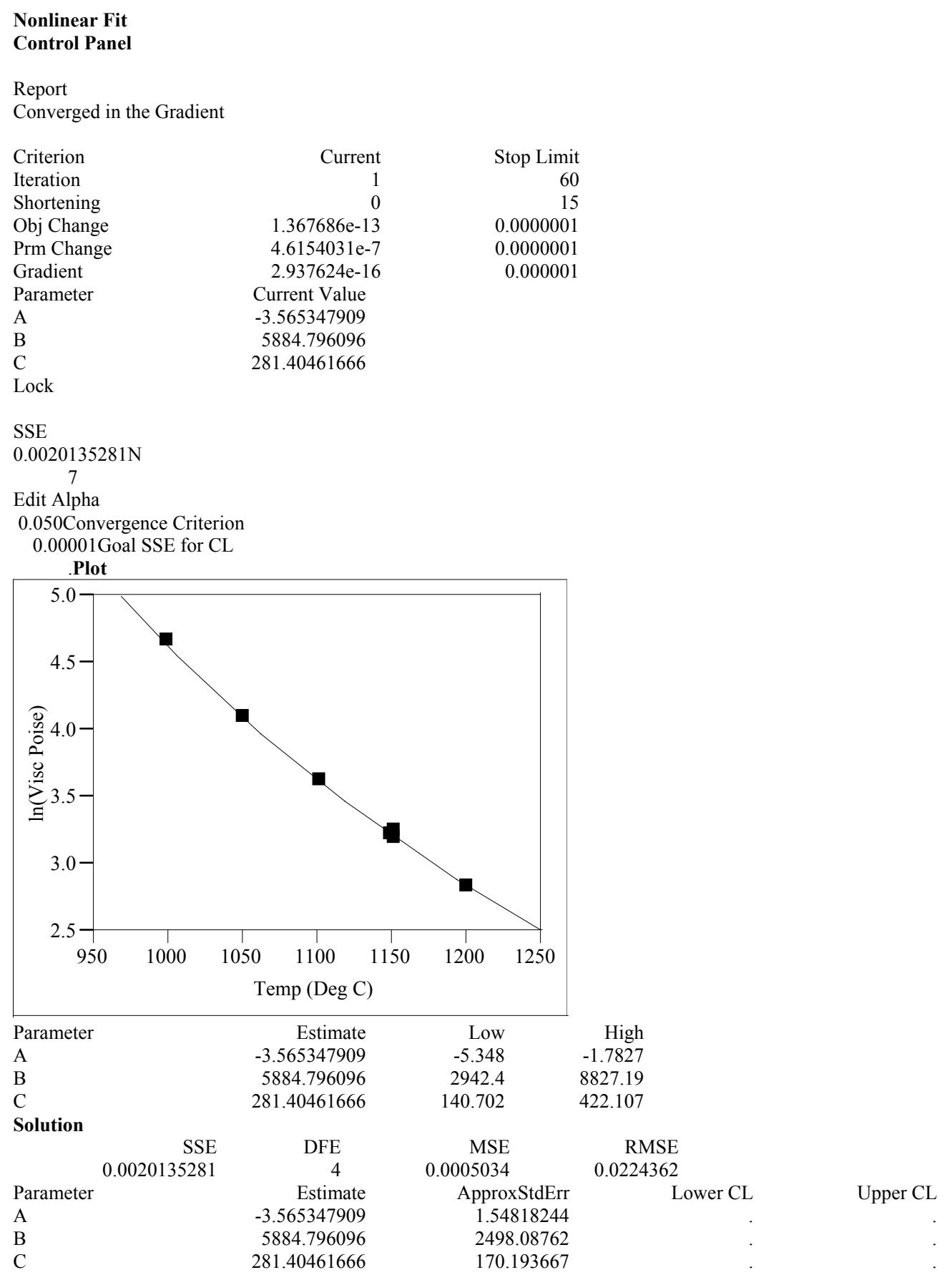


WSRC-TR-2004-00429

Revision 0

This page intentionally left blank. 


\section{APPENDIX F}

\section{Tables and Exhibits Supporting the Analysis of the PCT Results for the VIS Glasses}


Table F1. SRNL-ML Measurements of the PCT Solutions for the ADT - VIS Glasses

\begin{tabular}{|c|c|c|c|c|c|c|c|c|c|c|}
\hline Glass & SRNL-ML & & Seq & & As re & rted valu & in parts & er millio & (ppm) & \\
\hline ID & ID & Block & $\#$ & Al & B & $\mathbf{F e}$ & $\mathbf{L i}$ & $\mathbf{N a}$ & $\mathbf{S i}$ & $\mathbf{U}$ \\
\hline soln std & STD-B1-1 & 1 & 1 & 3.75 & 21.5 & 4.34 & 9.69 & 80 & 48.8 & $<0.100$ \\
\hline VIS-1ccc & pa39 & 1 & 2 & 6.32 & 10.4 & 7.53 & 15.9 & 51.2 & 94.4 & 3.35 \\
\hline VIS-4ccc & pa64 & 1 & 3 & 8.59 & 11.3 & 7.95 & 16.2 & 66.4 & 94.7 & 2.61 \\
\hline VIS-2ccc & pa80 & 1 & 4 & 6.82 & 9.92 & 6.04 & 15.4 & 55.3 & 91.3 & 2.55 \\
\hline VIS-1 & $\mathrm{pa05}$ & 1 & 5 & 5.94 & 9.81 & 6.11 & 15.2 & 53 & 92.4 & 3.36 \\
\hline VIS-3 & pa60 & 1 & 6 & 7.57 & 10.5 & 6.57 & 15.5 & 65.3 & 92.4 & 2.3 \\
\hline VIS-3ccc & pa33 & 1 & 7 & 7.31 & 10 & 5.57 & 15 & 59.1 & 90.4 & 2.49 \\
\hline soln std & STD-B1-2 & 1 & 8 & 3.71 & 20.4 & 4.4 & 9.67 & 79.5 & 48.8 & $<0.100$ \\
\hline VIS-5ccc & pa77 & 1 & 9 & 10.1 & 12.7 & 9.83 & 18 & 78.2 & 101 & 2.62 \\
\hline ARM & pa68 & 1 & 10 & 2.76 & 13.5 & $<0.010$ & 10 & 26.3 & 41.8 & $<0.100$ \\
\hline blank & pa27 & 1 & 11 & $<0.015$ & $<0.100$ & $<0.010$ & $<0.100$ & $<0.100$ & $<0.200$ & $<0.100$ \\
\hline VIS-4 & pa48 & 1 & 12 & 8 & 10.7 & 5.46 & 15.2 & 68.3 & 92.1 & 2.49 \\
\hline VIS-6 & pa56 & 1 & 13 & 12.5 & 13.5 & 9.12 & 16.7 & 97.8 & 97.1 & 2.89 \\
\hline VIS-6ccc & pa54 & 1 & 14 & 15.3 & 14.1 & 19 & 20.1 & 99 & 100 & 3.89 \\
\hline VIS-5 & $\mathrm{pa02}$ & 1 & 15 & 9.61 & 12 & 7.76 & 16.1 & 80.3 & 93.8 & 2.63 \\
\hline VIS-2 & pa23 & 1 & 16 & 7.01 & 9.79 & 7.21 & 15 & 59.7 & 92 & 2.95 \\
\hline soln std & STD-B1-3 & 1 & 17 & 3.67 & 19.7 & 4.31 & 9.66 & 79.1 & 48.9 & $<0.100$ \\
\hline soln std & STD-B2-1 & 2 & 1 & 3.77 & 21 & 4.23 & 9.57 & 79.2 & 48.2 & $<0.100$ \\
\hline VIS-2 & pa63 & 2 & 2 & 7 & 10.4 & 6.84 & 14.9 & 58.8 & 91.2 & 3.14 \\
\hline VIS-1ccc & pa20 & 2 & 3 & 6.27 & 10 & 6.04 & 16.5 & 53.7 & 95.7 & 2.89 \\
\hline VIS-6ccc & pa66 & 2 & 4 & 14.8 & 14.5 & 14.7 & 20.2 & 99.9 & 108 & 3.14 \\
\hline VIS-5ccc & pa53 & 2 & 5 & 10.8 & 12.4 & 12.4 & 17.7 & 77.7 & 101 & 3.27 \\
\hline EA & pa92 & 2 & 6 & 0.109 & 34.9 & $<0.010$ & 10.4 & 95.3 & 50.1 & $<0.100$ \\
\hline VIS-3ccc & pa59 & 2 & 7 & 7.48 & 10 & 5.9 & 15.1 & 61.1 & 89.7 & 2.63 \\
\hline soln std & STD-B2-2 & 2 & 8 & 3.77 & 19.9 & 4.27 & 9.6 & 80.8 & 48.1 & $<0.100$ \\
\hline VIS-4 & $\mathrm{pa01}$ & 2 & 9 & 8.3 & 11 & 6.48 & 15.2 & 68.8 & 91.6 & 2.52 \\
\hline VIS-3 & pa12 & 2 & 10 & 7.65 & 10 & 7.23 & 14.9 & 63.4 & 91.4 & 3.4 \\
\hline VIS-2ccc & pa29 & 2 & 11 & 6.95 & 9.63 & 5.98 & 15.4 & 56.2 & 92.2 & 2.61 \\
\hline VIS-4ccc & $\mathrm{pa} 04$ & 2 & 12 & 8.42 & 10.3 & 7.15 & 15.7 & 64 & 92.2 & 2.59 \\
\hline VIS-5 & pa82 & 2 & 13 & 9.46 & 11.5 & 6.8 & 15.9 & 78.8 & 92.9 & 2.53 \\
\hline VIS-1 & pa11 & 2 & 14 & 6.11 & 9.44 & 5.55 & 15.7 & 55.5 & 93.2 & 2.8 \\
\hline VIS-6 & pa37 & 2 & 15 & 12.4 & 13.3 & 7.99 & 16.7 & 98.3 & 95.1 & 2.79 \\
\hline soln std & STD-B2-3 & 2 & 16 & 3.79 & 19.8 & 4.34 & 9.63 & 79.8 & 48.4 & $<0.100$ \\
\hline soln std & STD-B3-1 & 3 & 1 & 3.82 & 20.6 & 4.42 & 9.7 & 79.1 & 48.9 & $<0.100$ \\
\hline ARM & pa38 & 3 & 2 & 2.79 & 13.9 & $<0.010$ & 9.52 & 25.9 & 39.8 & $<0.100$ \\
\hline VIS-1ccc & pa26 & 3 & 3 & 6.54 & 10.2 & 7.4 & 16.5 & 53 & 96.5 & 3.06 \\
\hline VIS-4ccc & pa75 & 3 & 4 & 9.02 & 11.1 & 9.53 & 16.3 & 67.7 & 96 & 3.03 \\
\hline VIS-6 & pa74 & 3 & 5 & 12.6 & 13.6 & 8.64 & 16.7 & 100 & 95.2 & 2.7 \\
\hline VIS-6ccc & pa34 & 3 & 6 & 15.3 & 13.9 & 18.6 & 19.8 & 99.3 & 106 & 3.81 \\
\hline VIS-2 & pa79 & 3 & 7 & 6.94 & 9.45 & 6.91 & 14.6 & 59.4 & 87.5 & 3.32 \\
\hline soln std & STD-B3-2 & 3 & 8 & 3.83 & 19.6 & 4.47 & 9.61 & 80.6 & 48 & $<0.100$ \\
\hline VIS-4 & pa31 & 3 & 9 & 8.46 & 10.8 & 6.56 & 15 & 68.1 & 89.5 & 2.55 \\
\hline VIS-3 & pa61 & 3 & 10 & 7.64 & 10.2 & 5.93 & 15.4 & 64.5 & 89.6 & 2.55 \\
\hline VIS-2ccc & pa50 & 3 & 11 & 7.1 & 9.34 & 6.77 & 15.2 & 55.5 & 89.3 & 2.69 \\
\hline VIS-1 & pa45 & 3 & 12 & 6.17 & 9.31 & 6.34 & 15.2 & 54.9 & 90.7 & 3.36 \\
\hline VIS-3ccc & pa10 & 3 & 13 & 7.89 & 9.65 & 7.79 & 15.2 & 61.6 & 91 & 2.92 \\
\hline VIS-5 & pa42 & 3 & 14 & 9.73 & 11 & 7.65 & 15.8 & 78.5 & 91.2 & 2.53 \\
\hline VIS-5ccc & pa35 & 3 & 15 & 10.8 & 11.6 & 12.4 & 17.4 & 77.7 & 97.8 & 3.43 \\
\hline soln std & STD-B3-3 & 3 & 16 & 3.83 & 19.4 & 4.43 & 9.63 & 80 & 47.5 & $<0.100$ \\
\hline soln std & STD-B4-1 & 4 & 1 & 3.78 & 21.3 & 4.28 & 9.74 & 81 & 48 & $<0.100$ \\
\hline ADT-7ccc & pa19 & 4 & 2 & 8.34 & 12.4 & 6.97 & 10.2 & 106 & 98.1 & 2.25 \\
\hline ADT-8ccc & pa70 & 4 & 3 & 11.5 & 12.7 & 11 & 10 & 115 & 95.6 & 2.91 \\
\hline ADT-8 & pa22 & 4 & 4 & 10.8 & 13.4 & 7.92 & 9.84 & 128 & 97.8 & 2.53 \\
\hline ADT-1 & pa69 & 4 & 5 & 5.41 & 9.32 & 3.6 & 11.5 & 47.8 & 76.3 & 2.14 \\
\hline EA & pa43 & 4 & 6 & 0.1 & 37.2 & $<0.010$ & 11.1 & 104 & 52 & $<0.100$ \\
\hline ADT-6ccc & pa90 & 4 & 7 & 14.3 & 16.8 & 19.8 & 21.9 & 125 & 120 & 4.18 \\
\hline
\end{tabular}


Table F1. SRNL-ML Measurements of the PCT Solutions for the ADT - VIS Glasses

\begin{tabular}{|c|c|c|c|c|c|c|c|c|c|c|}
\hline Glass & SRNL-ML & & Seq & & As re & rted valu & in parts & er millio & ppm) & \\
\hline ID & ID & Block & $\#$ & Al & B & $\mathbf{F e}$ & $\mathbf{L i}$ & $\mathbf{N a}$ & Si & $\mathbf{U}$ \\
\hline ADT-6 & pa62 & 4 & 8 & 12.8 & 17.4 & 13.1 & 20.8 & 136 & 123 & 3.46 \\
\hline ADT-3ccc & pa40 & 4 & 9 & 8.11 & 11.6 & 6.85 & 16.7 & 76.1 & 97.1 & 2.63 \\
\hline soln std & STD-B4-2 & 4 & 10 & 3.79 & 19.8 & 4.28 & 9.56 & 79.9 & 46.8 & $<0.100$ \\
\hline ADT-5ecc & pa71 & 4 & 11 & 9.68 & 15.3 & 11 & 21 & 107 & 118 & 3 \\
\hline ADT-7 & pa25 & 4 & 12 & 9.13 & 12.2 & 9.31 & 10.3 & 119 & 101 & 2.5 \\
\hline ADT-2 & pa87 & 4 & 13 & 7.09 & 10.2 & 4.3 & 11.8 & 59.9 & 78.2 & 2.07 \\
\hline ADT-2ccc & pa83 & 4 & 14 & 8.08 & 9.87 & 6.58 & 12.1 & 58 & 77.6 & 2.3 \\
\hline ADT-1ccc & pa91 & 4 & 15 & 5.62 & 8.9 & 3.69 & 11.3 & 45.6 & 75.6 & 2.24 \\
\hline ADT-3 & pa88 & 4 & 16 & 8.33 & 11.3 & 7.49 & 16.5 & 81.9 & 99.7 & 2.5 \\
\hline ADT-5 & pa67 & 4 & 17 & 9.15 & 14.9 & 8.17 & 20 & 113 & 117 & 3.08 \\
\hline ADT-4ccc & pa78 & 4 & 18 & 10.1 & 12.7 & 7.72 & 17.3 & 92.7 & 97.9 & 2.78 \\
\hline ADT-4 & pa21 & 4 & 19 & 10.8 & 13.2 & 10.1 & 17.5 & 100 & 102 & 2.88 \\
\hline soln std & STD-B4-3 & 4 & 20 & 3.75 & 19.5 & 4.24 & 9.69 & 82.1 & 47.5 & $<0.100$ \\
\hline soln std & STD-B5-1 & 5 & 1 & 3.79 & 21.5 & 4.31 & 9.71 & 80.6 & 49.4 & $<0.100$ \\
\hline ADT-5ccc & pa52 & 5 & 2 & 10.8 & 16 & 15.7 & 21.1 & 107 & 125 & 3.92 \\
\hline ADT-4ccc & pa32 & 5 & 3 & 9.98 & 14 & 7 & 17.6 & 94.8 & 102 & 2.72 \\
\hline ADT-3 & pa73 & 5 & 4 & 8.22 & 11.9 & 7.24 & 16.5 & 81.1 & 102 & 2.47 \\
\hline ADT-6ccc & pa28 & 5 & 5 & 14.6 & 17.6 & 21.2 & 23 & 130 & 116 & 4.4 \\
\hline ADT-3ccc & pa65 & 5 & 6 & 8.3 & 11.8 & 7.61 & 16.9 & 76.4 & 102 & 2.43 \\
\hline EA & pa36 & 5 & 7 & 0.099 & 38 & $<0.010$ & 11.2 & 102 & 53.7 & $<0.100$ \\
\hline ADT-8 & pa89 & 5 & 8 & 11.2 & 13.5 & 10.5 & 9.61 & 126 & 101 & 3.16 \\
\hline ADT-4 & pa17 & 5 & 9 & 11 & 13.9 & 11.8 & 17.5 & 100 & 107 & 3.38 \\
\hline soln std & STD-B4-2 & 5 & 10 & 3.79 & 20.7 & 4.34 & 9.86 & 82.7 & 50.4 & $<0.100$ \\
\hline ADT-1ccc & pa44 & 5 & 11 & 5.74 & 9.5 & 4.25 & 11.5 & 46.7 & 79.7 & 2.26 \\
\hline ADT-7ccc & $\mathrm{pa08}$ & 5 & 12 & 8.35 & 11.5 & 7.99 & 9.64 & 101 & 96.5 & 2.81 \\
\hline ADT-6 & pa16 & 5 & 13 & 12 & 17.9 & 11.3 & 21.2 & 137 & 125 & 3.16 \\
\hline ADT-1 & pa24 & 5 & 14 & 5.59 & 9.61 & 4.34 & 11.9 & 49.7 & 81.9 & 2.21 \\
\hline ADT-5 & pa14 & 5 & 15 & 10 & 14.7 & 12.8 & 19.7 & 112 & 122 & 3.78 \\
\hline ADT-7 & pa84 & 5 & 16 & 8.8 & 12.1 & 8.8 & 9.88 & 115 & 103 & 2.88 \\
\hline ADT-8ccc & pa51 & 5 & 17 & 10.5 & 12.5 & 8.32 & 10 & 115 & 95.9 & 2.6 \\
\hline ADT-2ccc & pa81 & 5 & 18 & 7.9 & 10 & 5.64 & 12.3 & 58.4 & 81.5 & 2.37 \\
\hline ADT-2 & pa46 & 5 & 19 & 7.1 & 10.2 & 4.45 & 11.9 & 61.1 & 80.7 & 2.24 \\
\hline soln std & STD-B5-3 & 5 & 20 & 3.76 & 20.3 & 4.24 & 9.87 & 84 & 50.1 & $<0.100$ \\
\hline soln std & STD-B6-1 & 6 & 1 & 3.79 & 21.5 & 4.28 & 9.69 & 80.4 & 48.8 & $<0.100$ \\
\hline ADT-3ccc & pa41 & 6 & 2 & 7.68 & 12.9 & 5.4 & 16.8 & 76.5 & 98.8 & 2.49 \\
\hline ADT-7 & pa86 & 6 & 3 & 8.88 & 13.3 & 7.83 & 10.1 & 114 & 103 & 2.55 \\
\hline ADT-4 & pa47 & 6 & 4 & 11.1 & 14.3 & 12.8 & 16.9 & 96.2 & 105 & 3.62 \\
\hline ADT-5ccc & pa58 & 6 & 5 & & & & & & & \\
\hline ADT-3 & pa57 & 6 & 6 & 8.18 & 12.2 & 7.13 & 16.4 & 79.9 & 101 & 2.44 \\
\hline ADT-8 & pa15 & 6 & 7 & 11.1 & 13.8 & 8.89 & 9.8 & 124 & 99.9 & 2.54 \\
\hline ADT-6 & $\mathrm{pa03}$ & 6 & 8 & 13.1 & 17.1 & 15.1 & 19.8 & 125 & 122 & 4.15 \\
\hline ARM & pa72 & 6 & 9 & 2.73 & 14.7 & 0.114 & 10 & 28 & 41.3 & $<0.100$ \\
\hline soln std & STD-B6-2 & 6 & 10 & 3.78 & 20.7 & 4.26 & 9.59 & 78.4 & 48.9 & $<0.100$ \\
\hline ADT-6ccc & pa18 & 6 & 11 & 12.8 & 18.4 & 14 & 22.9 & 126 & 129 & 3.58 \\
\hline ADT-5 & pa13 & 6 & 12 & 10.2 & 15.4 & 13.6 & 19.3 & 108 & 121 & 3.94 \\
\hline ADT-8ccc & pa55 & 6 & 13 & 10.8 & 13.9 & 8.59 & 10.1 & 116 & 97.2 & 2.5 \\
\hline ADT-4ccc & pa30 & 6 & 14 & 10.1 & 14.3 & 7.59 & 17.2 & 91.3 & 102 & 2.66 \\
\hline blank & $\mathrm{pa09}$ & 6 & 15 & 0.025 & 0.601 & $<0.010$ & $<0.100$ & $<0.100$ & $<0.200$ & $<0.100$ \\
\hline ADT-2 & pa76 & 6 & 16 & 6.93 & 11.2 & 3.76 & 12.1 & 59.9 & 81.1 & 2.06 \\
\hline ADT-7ccc & pa85 & 6 & 17 & 8.3 & 11.9 & 6.71 & 9.89 & 102 & 96.7 & 2.35 \\
\hline ADT-1 & $\mathrm{pa06}$ & 6 & 18 & 5.42 & 9.44 & 3.26 & 11.3 & 45.3 & 78.4 & 2.2 \\
\hline ADT-1ccc & pa49 & 6 & 19 & 5.63 & 9.55 & 3.88 & 11.4 & 45.3 & 78.5 & 2.18 \\
\hline ADT-2ccc & $\mathrm{pa07}$ & 6 & 20 & 7.77 & 10.5 & 5.56 & 12.1 & 57.1 & 79.3 & 2.25 \\
\hline soln std & STD-B6-3 & 6 & 21 & 3.78 & 20.7 & 4.26 & 9.67 & 80.1 & 49 & $<0.100$ \\
\hline
\end{tabular}


Table F2. SRNL-ML Measurements of the PCT Solutions for the VIS - ADT Glasses After Appropriate Adjustments

\begin{tabular}{|c|c|c|c|c|c|c|c|c|c|c|}
\hline "Glass & SRNL-ML & & Seq & \multicolumn{7}{|c|}{ Values in parts per million (ppm) } \\
\hline ID & ID & Block & \# & Al & $\mathbf{B}$ & $\mathbf{F e}$ & $\mathbf{L i}$ & $\mathbf{N a}$ & $\mathbf{S i}$ & $\mathbf{U}$ \\
\hline soln std & STD-B1-1 & 1 & 1 & 3.750 & 21.500 & 4.340 & 9.690 & 80.000 & 48.800 & 0.050 \\
\hline VIS-1ccc & Pa39 & 1 & 2 & 10.534 & 17.334 & 12.550 & 26.501 & 85.335 & 157.336 & 5.583 \\
\hline VIS-4cce & Pa64 & 1 & 3 & 14.317 & 18.834 & 13.250 & 27.001 & 110.669 & 157.836 & 4.350 \\
\hline VIS-2ccc & $\mathrm{Pa} 80$ & 1 & 4 & 11.367 & 16.534 & 10.067 & 25.667 & 92.169 & 152.170 & 4.250 \\
\hline VIS-1 & $\mathrm{Pa} 05$ & 1 & 5 & 9.900 & 16.350 & 10.184 & 25.334 & 88.335 & 154.003 & 5.600 \\
\hline VIS-3 & $\mathrm{Pa} 60$ & 1 & 6 & 12.617 & 17.500 & 10.950 & 25.834 & 108.836 & 154.003 & 3.833 \\
\hline VIS-3ccc & $\mathrm{Pa} 33$ & 1 & 7 & 12.184 & 16.667 & 9.284 & 25.001 & 98.502 & 150.670 & 4.150 \\
\hline soln std & STD-B1-2 & 1 & 8 & 3.710 & 20.400 & 4.400 & 9.670 & 79.500 & 48.800 & 0.050 \\
\hline VIS-5ccc & $\mathrm{Pa} 77$ & 1 & 9 & 16.834 & 21.167 & 16.384 & 30.001 & 130.336 & 168.337 & 4.367 \\
\hline ARM & $\mathrm{Pa} 68$ & 1 & 10 & 4.600 & 22.500 & 0.008 & 16.667 & 43.834 & 69.668 & 0.083 \\
\hline blank & $\mathrm{Pa} 27$ & 1 & 11 & 0.013 & 0.083 & 0.008 & 0.083 & 0.083 & 0.167 & 0.083 \\
\hline VIS-4 & $\mathrm{Pa} 48$ & 1 & 12 & 13.334 & 17.834 & 9.100 & 25.334 & 113.836 & 153.503 & 4.150 \\
\hline VIS-6 & Pa56 & 1 & 13 & 20.834 & 22.500 & 15.200 & 27.834 & 163.003 & 161.837 & 4.817 \\
\hline VIS-6ccc & $\mathrm{Pa} 54$ & 1 & 14 & 25.501 & 23.500 & 31.667 & 33.501 & 165.003 & 166.670 & 6.483 \\
\hline VIS-5 & $\mathrm{Pa} 02$ & 1 & 15 & 16.017 & 20.000 & 12.934 & 26.834 & 133.836 & 156.336 & 4.383 \\
\hline VIS-2 & $\mathrm{Pa} 23$ & 1 & 16 & 11.684 & 16.317 & 12.017 & 25.001 & 99.502 & 153.336 & 4.917 \\
\hline soln std & STD-B1-3 & 1 & 17 & 3.670 & 19.700 & 4.310 & 9.660 & 79.100 & 48.900 & 0.050 \\
\hline soln std & STD-B2-1 & 2 & 1 & 3.770 & 21.000 & 4.230 & 9.570 & 79.200 & 48.200 & 0.050 \\
\hline VIS-2 & Pa63 & 2 & 2 & 11.667 & 17.334 & 11.400 & 24.834 & 98.002 & 152.003 & 5.233 \\
\hline VIS-1cce & $\mathrm{Pa} 20$ & 2 & 3 & 10.450 & 16.667 & 10.067 & 27.501 & 89.502 & 159.503 & 4.817 \\
\hline VIS-6ccc & $\mathrm{Pa} 66$ & 2 & 4 & 24.667 & 24.167 & 24.500 & 33.667 & 166.503 & 180.004 & 5.233 \\
\hline VIS-5cce & Pa53 & 2 & 5 & 18.000 & 20.667 & 20.667 & 29.501 & 129.503 & 168.337 & 5.450 \\
\hline EA & $\mathrm{Pa} 92$ & 2 & 6 & 1.817 & 581.668 & 0.083 & 173.334 & 1588.337 & 835.002 & 0.833 \\
\hline VIS-3ccc & Pa59 & 2 & 7 & 12.467 & 16.667 & 9.834 & 25.167 & 101.835 & 149.503 & 4.383 \\
\hline soln std & STD-B2-2 & 2 & 8 & 3.770 & 19.900 & 4.270 & 9.600 & 80.800 & 48.100 & 0.050 \\
\hline VIS-4 & $\mathrm{Pa} 01$ & 2 & 9 & 13.834 & 18.334 & 10.800 & 25.334 & 114.669 & 152.670 & 4.200 \\
\hline VIS-3 & $\mathrm{Pa} 12$ & 2 & 10 & 12.750 & 16.667 & 12.050 & 24.834 & 105.669 & 152.336 & 5.667 \\
\hline VIS-2ccc & $\mathrm{Pa} 29$ & 2 & 11 & 11.584 & 16.050 & 9.967 & 25.667 & 93.669 & 153.670 & 4.350 \\
\hline VIS-4cce & $\mathrm{Pa} 04$ & 2 & 12 & 14.034 & 17.167 & 11.917 & 26.167 & 106.669 & 153.670 & 4.317 \\
\hline VIS-5 & $\mathrm{Pa} 82$ & 2 & 13 & 15.767 & 19.167 & 11.334 & 26.501 & 131.336 & 154.836 & 4.217 \\
\hline VIS-1 & $\mathrm{Pa} 11$ & 2 & 14 & 10.184 & 15.734 & 9.250 & 26.167 & 92.502 & 155.336 & 4.667 \\
\hline VIS-6 & Pa37 & 2 & 15 & 20.667 & 22.167 & 13.317 & 27.834 & 163.837 & 158.503 & 4.650 \\
\hline soln std & STD-B2-3 & 2 & 16 & 3.790 & 19.800 & 4.340 & 9.630 & 79.800 & 48.400 & 0.050 \\
\hline soln std & STD-B3-1 & 3 & 1 & 3.820 & 20.600 & 4.420 & 9.700 & 79.100 & 48.900 & 0.050 \\
\hline ARM & $\mathrm{Pa} 38$ & 3 & 2 & 4.650 & 23.167 & 0.008 & 15.867 & 43.168 & 66.335 & 0.083 \\
\hline VIS-1ccc & $\mathrm{Pa} 26$ & 3 & 3 & 10.900 & 17.000 & 12.334 & 27.501 & 88.335 & 160.837 & 5.100 \\
\hline VIS-4cce & $\mathrm{Pa} 75$ & 3 & 4 & 15.034 & 18.500 & 15.884 & 27.167 & 112.836 & 160.003 & 5.050 \\
\hline VIS-6 & $\mathrm{Pa} 74$ & 3 & 5 & 21.000 & 22.667 & 14.400 & 27.834 & 166.670 & 158.670 & 4.500 \\
\hline VIS-6cce & $\mathrm{Pa} 34$ & 3 & 6 & 25.501 & 23.167 & 31.001 & 33.001 & 165.503 & 176.670 & 6.350 \\
\hline VIS-2 & $\mathrm{Pa} 79$ & 3 & 7 & 11.567 & 15.750 & 11.517 & 24.334 & 99.002 & 145.836 & 5.533 \\
\hline soln std & STD-B3-2 & 3 & 8 & 3.830 & 19.600 & 4.470 & 9.610 & 80.600 & 48.000 & 0.050 \\
\hline VIS-4 & $\mathrm{Pa} 31$ & 3 & 9 & 14.100 & 18.000 & 10.934 & 25.001 & 113.502 & 149.170 & 4.250 \\
\hline VIS-3 & Pa61 & 3 & 10 & 12.734 & 17.000 & 9.884 & 25.667 & 107.502 & 149.336 & 4.250 \\
\hline VIS-2cce & $\mathrm{Pa} 50$ & 3 & 11 & 11.834 & 15.567 & 11.284 & 25.334 & 92.502 & 148.836 & 4.483 \\
\hline VIS-1 & $\mathrm{Pa} 45$ & 3 & 12 & 10.284 & 15.517 & 10.567 & 25.334 & 91.502 & 151.170 & 5.600 \\
\hline VIS-3cce & Pa10 & 3 & 13 & 13.150 & 16.084 & 12.984 & 25.334 & 102.669 & 151.670 & 4.867 \\
\hline VIS-5 & $\mathrm{Pa} 42$ & 3 & 14 & 16.217 & 18.334 & 12.750 & 26.334 & 130.836 & 152.003 & 4.217 \\
\hline VIS-5ccc & $\mathrm{Pa} 35$ & 3 & 15 & 18.000 & 19.334 & 20.667 & 29.001 & 129.503 & 163.003 & 5.717 \\
\hline soln std & STD-B3-3 & 3 & 16 & 3.830 & 19.400 & 4.430 & 9.630 & 80.000 & 47.500 & 0.050 \\
\hline soln std & STD-B4-1 & 4 & 1 & 3.780 & 21.300 & 4.280 & 9.740 & 81.000 & 48.000 & 0.050 \\
\hline ADT-7ccc & Pa19 & 4 & 2 & 13.900 & 20.667 & 11.617 & 17.000 & 176.670 & 163.503 & 3.750 \\
\hline ADT-8ccc & $\mathrm{Pa} 70$ & 4 & 3 & 19.167 & 21.167 & 18.334 & 16.667 & 191.671 & 159.337 & 4.850 \\
\hline ADT-8 & $\mathrm{Pa} 22$ & 4 & 4 & 18.000 & 22.334 & 13.200 & 16.400 & 213.338 & 163.003 & 4.217 \\
\hline ADT-1 & Pa69 & 4 & 5 & 9.017 & 15.534 & 6.000 & 19.167 & 79.668 & 127.169 & 3.567 \\
\hline EA & $\mathrm{Pa} 43$ & 4 & 6 & 1.667 & 620.001 & 0.083 & 185.000 & 1733.337 & 866.668 & 0.833 \\
\hline ADT-6ccc & $\mathrm{Pa} 90$ & 4 & 7 & 23.834 & 28.001 & 33.001 & 36.501 & 208.338 & 200.004 & 6.967 \\
\hline ADT-6 & $\mathrm{Pa} 62$ & 4 & 8 & 21.334 & 29.001 & 21.834 & 34.667 & 226.671 & 205.004 & 5.767 \\
\hline
\end{tabular}


Table F2. SRNL-ML Measurements of the PCT Solutions for the VIS - ADT Glasses After Appropriate Adjustments

\begin{tabular}{|c|c|c|c|c|c|c|c|c|c|c|}
\hline \multirow{2}{*}{$\begin{array}{c}\text { Glass } \\
\text { ID }\end{array}$} & \multirow{2}{*}{$\begin{array}{c}\text { SRNL-ML } \\
\text { ID }\end{array}$} & \multirow[b]{2}{*}{ Block } & \multirow{2}{*}{$\frac{\text { Seq }}{\#}$} & \multicolumn{7}{|c|}{ Values in parts per million (ppm) } \\
\hline & & & & Al & $\mathbf{B}$ & $\mathbf{F e}$ & $\mathbf{L i}$ & $\mathbf{N a}$ & $\mathbf{S i}$ & $\mathbf{U}$ \\
\hline ADT-3ccc & $\mathrm{Pa} 40$ & 4 & 9 & 13.517 & 19.334 & 11.417 & 27.834 & 126.836 & 161.837 & 4.383 \\
\hline soln std & STD-B4-2 & 4 & 10 & 3.790 & 19.800 & 4.280 & 9.560 & 79.900 & 46.800 & 0.050 \\
\hline ADT-5ccc & $\mathrm{Pa} 71$ & 4 & 11 & 16.134 & 25.501 & 18.334 & 35.001 & 178.337 & 196.671 & 5.000 \\
\hline ADT-7 & $\mathrm{Pa} 25$ & 4 & 12 & 15.217 & 20.334 & 15.517 & 17.167 & 198.337 & 168.337 & 4.167 \\
\hline ADT-2 & $\mathrm{Pa} 87$ & 4 & 13 & 11.817 & 17.000 & 7.167 & 19.667 & 99.835 & 130.336 & 3.450 \\
\hline ADT-2ccc & $\mathrm{Pa} 83$ & 4 & 14 & 13.467 & 16.450 & 10.967 & 20.167 & 96.669 & 129.336 & 3.833 \\
\hline ADT-1ccc & $\mathrm{Pa91}$ & 4 & 15 & 9.367 & 14.834 & 6.150 & 18.834 & 76.002 & 126.003 & 3.733 \\
\hline ADT-3 & $\mathrm{Pa} 88$ & 4 & 16 & 13.884 & 18.834 & 12.484 & 27.501 & 136.503 & 166.170 & 4.167 \\
\hline ADT-5 & $\mathrm{Pa} 67$ & 4 & 17 & 15.250 & 24.834 & 13.617 & 33.334 & 188.337 & 195.004 & 5.133 \\
\hline ADT-4ccc & $\mathrm{Pa} 78$ & 4 & 18 & 16.834 & 21.167 & 12.867 & 28.834 & 154.503 & 163.170 & 4.633 \\
\hline ADT-4 & $\mathrm{Pa} 21$ & 4 & 19 & 18.000 & 22.000 & 16.834 & 29.167 & 166.670 & 170.003 & 4.800 \\
\hline soln std & STD-B4-3 & 4 & 20 & 3.750 & 19.500 & 4.240 & 9.690 & 82.100 & 47.500 & 0.050 \\
\hline soln std & STD-B5-1 & 5 & 1 & 3.790 & 21.500 & 4.310 & 9.710 & 80.600 & 49.400 & 0.050 \\
\hline ADT-5ccc & $\mathrm{Pa} 52$ & 5 & 2 & 18.000 & 26.667 & 26.167 & 35.167 & 178.337 & 208.338 & 6.533 \\
\hline ADT-4ccc & $\mathrm{Pa} 32$ & 5 & 3 & 16.634 & 23.334 & 11.667 & 29.334 & 158.003 & 170.003 & 4.533 \\
\hline ADT-3 & $\mathrm{Pa} 73$ & 5 & 4 & 13.700 & 19.834 & 12.067 & 27.501 & 135.169 & 170.003 & 4.117 \\
\hline ADT-6ccc & $\mathrm{Pa} 28$ & 5 & 5 & 24.334 & 29.334 & 35.334 & 38.334 & 216.671 & 193.337 & 7.333 \\
\hline ADT-3ccc & $\mathrm{Pa} 65$ & 5 & 6 & 13.834 & 19.667 & 12.684 & 28.167 & 127.336 & 170.003 & 4.050 \\
\hline EA & $\mathrm{Pa} 36$ & 5 & 7 & 1.650 & 633.335 & 0.083 & 186.667 & 1700.003 & 895.002 & 0.833 \\
\hline ADT-8 & $\mathrm{Pa} 89$ & 5 & 8 & 18.667 & 22.500 & 17.500 & 16.017 & 210.004 & 168.337 & 5.267 \\
\hline ADT-4 & $\mathrm{Pa} 17$ & 5 & 9 & 18.334 & 23.167 & 19.667 & 29.167 & \begin{tabular}{|l|}
166.670 \\
\end{tabular} & 178.337 & 5.633 \\
\hline soln std & STD-B4-2 & 5 & 10 & 3.790 & 20.700 & 4.340 & 9.860 & 82.700 & 50.400 & 0.050 \\
\hline ADT-1ccc & $\mathrm{Pa} 44$ & 5 & 11 & 9.567 & 15.834 & 7.083 & 19.167 & 77.835 & 132.836 & 3.767 \\
\hline ADT-7ccc & $\mathrm{Pa} 08$ & 5 & 12 & 13.917 & 19.167 & 13.317 & 16.067 & 168.337 & 160.837 & 4.683 \\
\hline ADT-6 & $\mathrm{Pa} 16$ & 5 & 13 & 20.000 & 29.834 & 18.834 & 35.334 & 228.338 & 208.338 & 5.267 \\
\hline ADT-1 & $\mathrm{Pa} 24$ & 5 & 14 & 9.317 & 16.017 & 7.233 & 19.834 & 82.835 & 136.503 & 3.683 \\
\hline ADT-5 & $\mathrm{Pa} 14$ & 5 & 15 & 16.667 & 24.500 & 21.334 & 32.834 & 186.670 & 203.337 & 6.300 \\
\hline ADT-7 & $\mathrm{Pa} 84$ & 5 & 16 & 14.667 & 20.167 & 14.667 & 16.467 & 191.671 & 171.670 & 4.800 \\
\hline ADT-8ccc & $\mathrm{Pa} 51$ & 5 & 17 & 17.500 & 20.834 & 13.867 & 16.667 & 191.671 & 159.837 & 4.333 \\
\hline ADT-2ccc & $\mathrm{Pa} 81$ & 5 & 18 & 13.167 & 16.667 & 9.400 & 20.500 & 97.335 & 135.836 & 3.950 \\
\hline ADT-2 & $\mathrm{Pa} 46$ & 5 & 19 & 11.834 & 17.000 & 7.417 & 19.834 & 101.835 & 134.503 & 3.733 \\
\hline soln std & STD-B5-3 & 5 & 20 & 3.760 & 20.300 & 4.240 & 9.870 & 84.000 & 50.100 & 0.050 \\
\hline soln std & STD-B6-1 & 6 & 1 & 3.790 & 21.500 & 4.280 & 9.690 & 80.400 & 48.800 & 0.050 \\
\hline ADT-3ccc & $\mathrm{Pa} 41$ & 6 & 2 & 12.800 & 21.500 & 9.000 & 28.001 & 127.503 & 164.670 & 4.150 \\
\hline ADT-7 & $\mathrm{Pa} 86$ & 6 & 3 & 14.800 & 22.167 & 13.050 & 16.834 & 190.004 & 171.670 & 4.250 \\
\hline ADT-4 & $\mathrm{Pa} 47$ & 6 & 4 & 18.500 & 23.834 & 21.334 & 28.167 & 160.337 & 175.004 & 6.033 \\
\hline ADT-5ccc & Pa58-missing & 6 & 5 & . & . & . & . & . & . & . \\
\hline ADT-3 & $\mathrm{Pa} 57$ & 6 & 6 & 13.634 & 20.334 & 11.884 & 27.334 & 133.169 & 168.337 & 4.067 \\
\hline ADT-8 & $\mathrm{Pa} 15$ & 6 & 7 & 18.500 & 23.000 & 14.817 & 16.334 & 206.671 & 166.503 & 4.233 \\
\hline ADT-6 & $\mathrm{Pa} 03$ & 6 & 8 & 21.834 & 28.501 & 25.167 & 33.001 & 208.338 & 203.337 & 6.917 \\
\hline ARM & $\mathrm{Pa} 72$ & 6 & 9 & 4.550 & 24.500 & 0.190 & 16.667 & 46.668 & 68.835 & 0.083 \\
\hline soln std & STD-B6-2 & 6 & 10 & 3.780 & 20.700 & 4.260 & 9.590 & 78.400 & 48.900 & 0.050 \\
\hline ADT-6ccc & $\mathrm{Pa} 18$ & 6 & 11 & 21.334 & 30.667 & 23.334 & 38.167 & 210.004 & 215.004 & 5.967 \\
\hline ADT-5 & $\mathrm{Pa} 13$ & 6 & 12 & 17.000 & 25.667 & 22.667 & 32.167 & \begin{tabular}{|l|}
180.004 \\
\end{tabular} & 201.671 & 6.567 \\
\hline ADT-8ccc & $\mathrm{Pa} 55$ & 6 & 13 & 18.000 & 23.167 & 14.317 & 16.834 & 193.337 & 162.003 & 4.167 \\
\hline ADT-4ccc & $\mathrm{Pa} 30$ & 6 & 14 & 16.834 & 23.834 & 12.650 & 28.667 & 152.170 & 170.003 & 4.433 \\
\hline blank & $\mathrm{Pa} 09$ & 6 & 15 & 0.042 & 1.002 & 0.008 & 0.083 & 0.083 & 0.167 & 0.083 \\
\hline ADT-2 & $\mathrm{Pa} 76$ & 6 & 16 & 11.550 & 18.667 & 6.267 & 20.167 & 99.835 & 135.169 & 3.433 \\
\hline ADT-7ccc & $\mathrm{Pa} 85$ & 6 & 17 & 13.834 & 19.834 & 11.184 & 16.484 & 170.003 & 161.170 & 3.917 \\
\hline ADT-1 & $\mathrm{Pa} 06$ & 6 & 18 & 9.034 & 15.734 & 5.433 & 18.834 & 75.502 & 130.669 & 3.667 \\
\hline ADT-1ccc & $\mathrm{Pa} 49$ & 6 & 19 & 9.384 & 15.917 & 6.467 & 19.000 & 75.502 & 130.836 & 3.633 \\
\hline ADT-2ccc & $\mathrm{Pa} 07$ & 6 & 20 & 12.950 & 17.500 & 9.267 & 20.167 & 95.169 & 132.169 & 3.750 \\
\hline soln std & STD-B6-3 & 6 & 21 & 3.780 & 20.700 & 4.260 & 9.670 & 80.100 & 49.000 & 0.050 \\
\hline
\end{tabular}




\section{Exhibit F1. SRNL-ML PCT Measurements in Analytical Sequence for ADT - VIS Study Glasses, EA, ARM, Blanks, and Solution Standards}
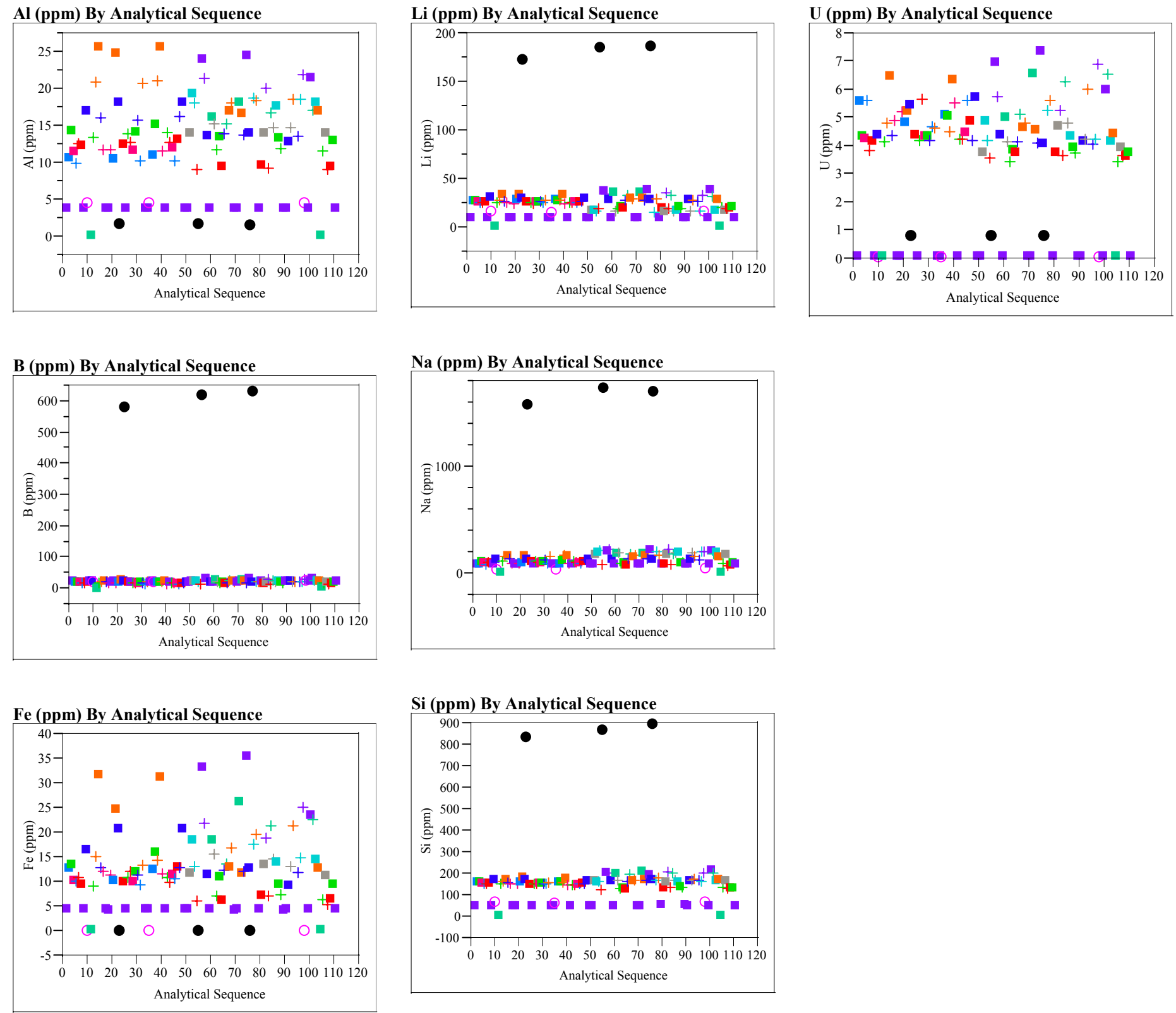


\section{Exhibit F2. SRNL-ML PCT Measurements in Analytical Sequence for VIS Study Glasses Only}
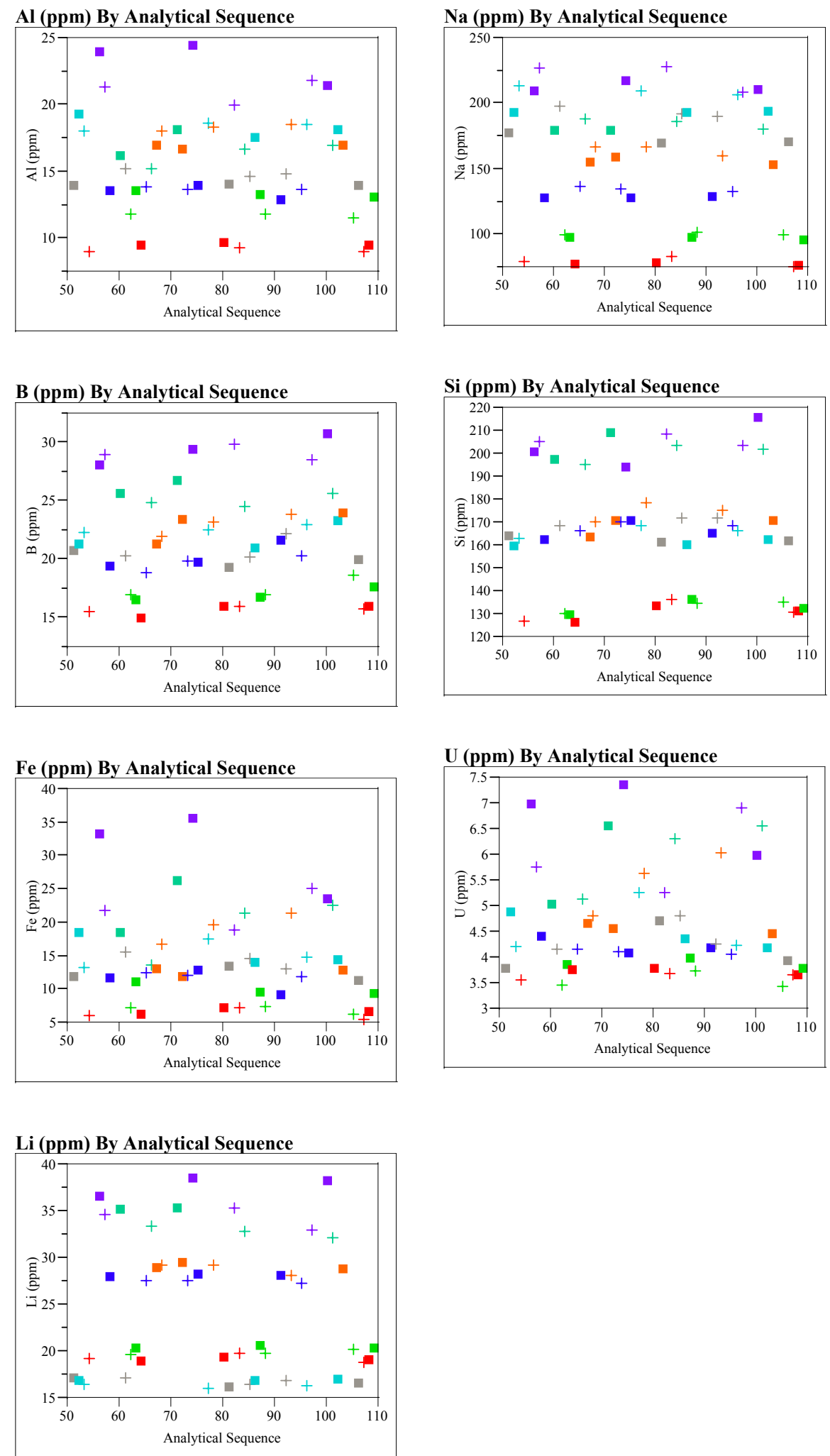


\section{Exhibit F3. Measurements of the Multi-Element Solution Standard by ICP Block}

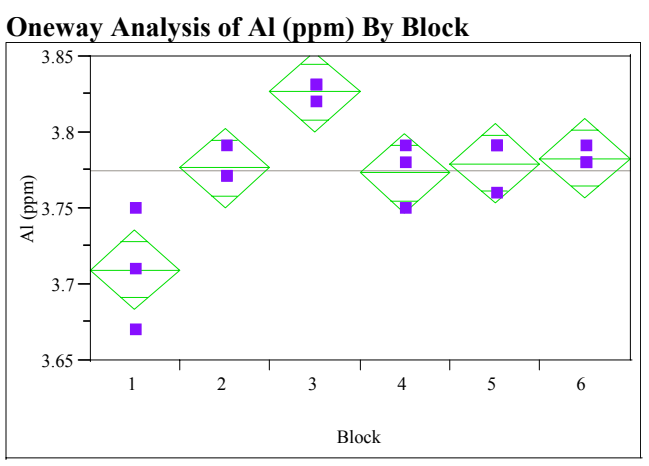

Oneway Anova

Summary of Fit

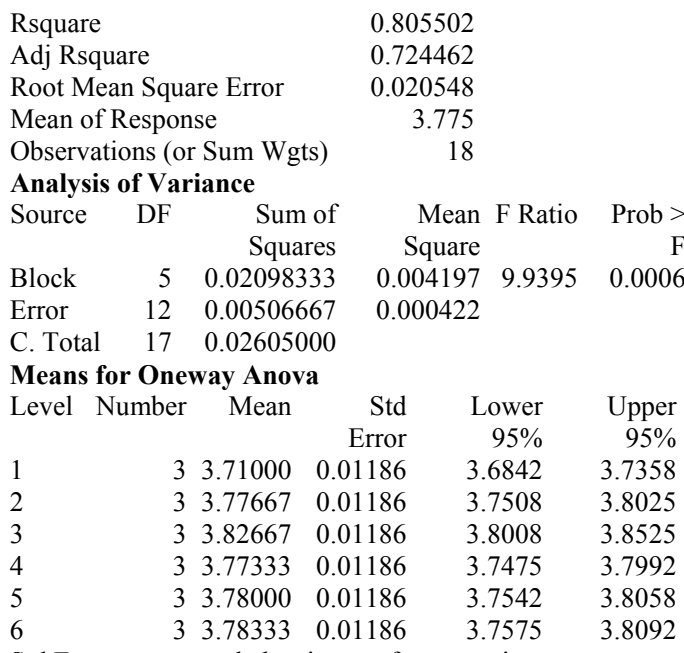

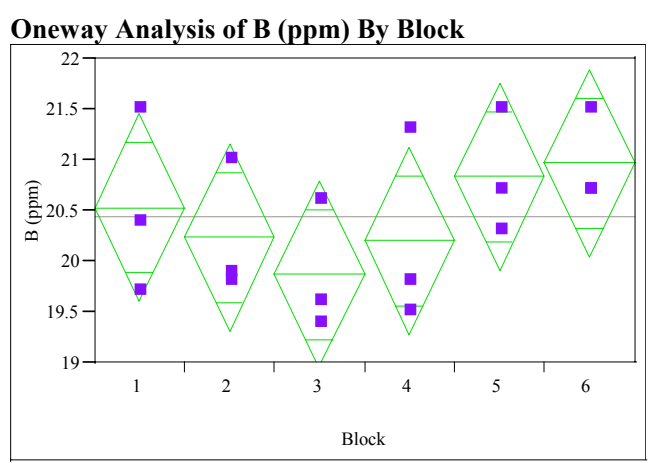

\section{Oneway Anova}

Summary of Fit

\begin{tabular}{|c|c|c|c|c|c|c|}
\hline \multicolumn{3}{|l|}{ Rsquare } & \multicolumn{3}{|c|}{0.289849} & \\
\hline & \multicolumn{3}{|c|}{-0.00605} & \\
\hline \multirow{2}{*}{\multicolumn{3}{|c|}{ Root Mean Square Error }} & \multicolumn{3}{|c|}{0.729916} & \\
\hline & & & \multicolumn{3}{|c|}{20.43889} & \\
\hline \multicolumn{3}{|c|}{$\begin{array}{l}\text { Mean of Response } \\
\text { Observations (or Sum Wgts) }\end{array}$} & & 18 & & \\
\hline \multicolumn{7}{|c|}{ Analysis of Variance } \\
\hline Source & DF & $\begin{array}{l}\text { Sum of } \\
\text { Squares }\end{array}$ & & $\begin{array}{r}\text { Mean } \\
\text { Square }\end{array}$ & F Ratio & 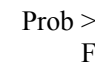 \\
\hline Block & 5 & 2.609444 & \multicolumn{2}{|c|}{0.521889} & 9.9796 & 0.400 \\
\hline Error & 12 & 6.39333 & & \multicolumn{2}{|c|}{0.532778} & \\
\hline C. Total & 17 & $9.00277^{\prime}$ & & & & \\
\hline \multicolumn{7}{|c|}{ Means for Oneway Anova } \\
\hline \multicolumn{2}{|c|}{ Level Number } & Mean & $\begin{array}{r}\text { St } \\
\text { Erro }\end{array}$ & & $\begin{array}{r}\text { Lower } \\
95 \%\end{array}$ & $\begin{array}{r}\text { Upper } \\
95 \%\end{array}$ \\
\hline 1 & & 20.5333 & 0.42142 & & 19.615 & 21.452 \\
\hline 2 & & 20.2333 & 0.4214 & & 19.315 & 15 \\
\hline 3 & 3 & 19.8667 & 0.4214 & & 18.948 & 0.785 \\
\hline 4 & 3 & 20.2000 & 0.4214 & & 19.282 & 21.118 \\
\hline 5 & 3 & 20.8333 & 0.4214 & & 19.915 & 21.752 \\
\hline & 3 & 20.9667 & 0.4214 & & 20.048 & 21.885 \\
\hline
\end{tabular}

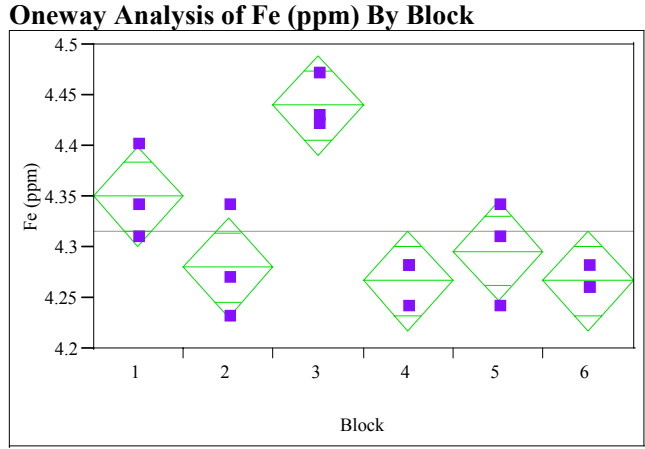

Oneway Anova

Summary of Fit

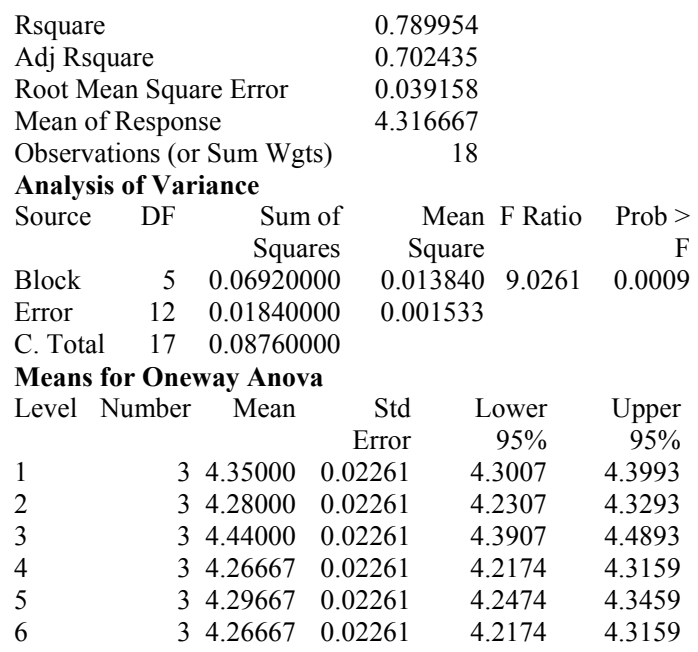

Std Error uses a pooled estimate of error variance 


\section{Exhibit F3. Measurements of the Multi-Element Solution Standard by ICP Block}

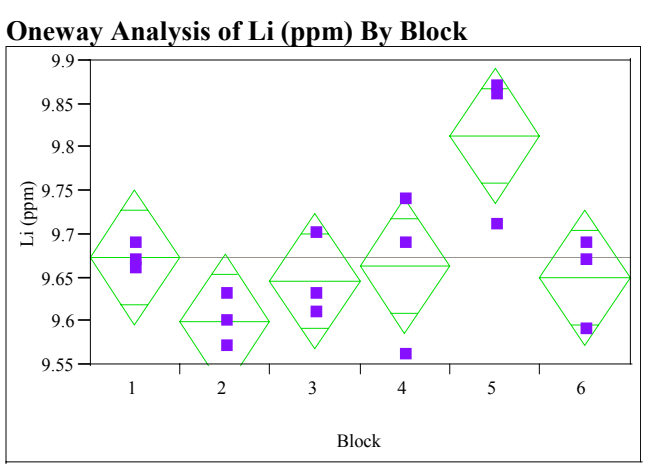

Oneway Anova

Summary of Fit

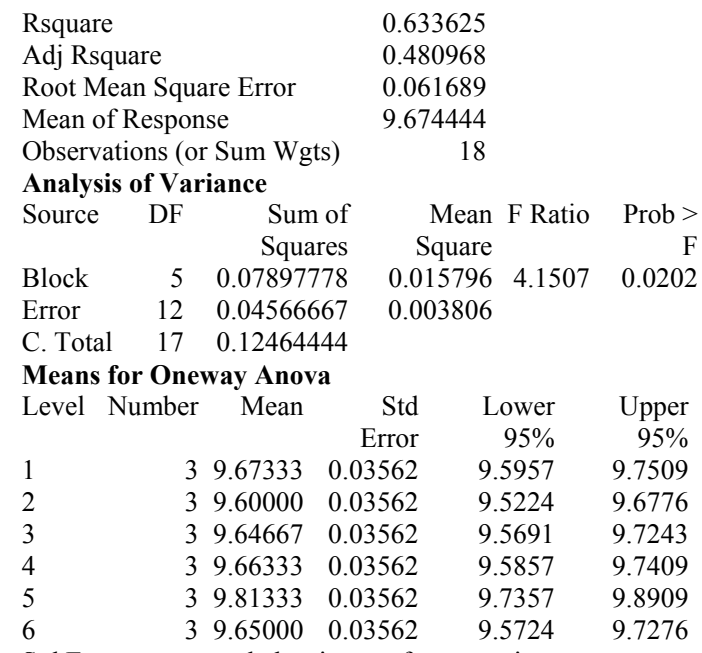

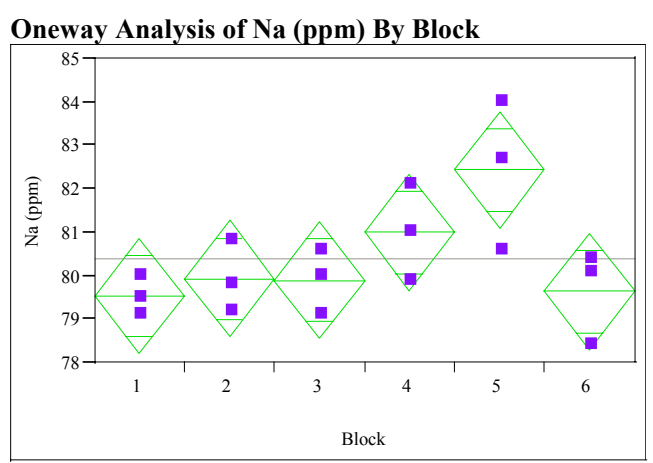

\section{Oneway Anova}

Summary of Fit

\section{Rsquare}

Adj Rsquare

Root Mean Square Error

Mean of Response

Observations (or Sum Wgts)

Analysis of Variance

Source DF Sum of Mean F Ratio Prob $>$ F

$\begin{array}{rrr}\text { Source DF } & \begin{array}{r}\text { Sum of } \\ \text { Squares }\end{array} & \text { Square } \\ & & \end{array}$

$\begin{array}{lrrrrr} & & \text { Squares } & \text { Square } & & \\ \text { Block } & 5 & 18.902778 & 3.78056 & 3.3638 & 0.0395\end{array}$

$\begin{array}{llll}\text { Error } & 12 & 13.486667 & 1.12389\end{array}$

$\begin{array}{lll}\text { C. Total } & 17 & 32.389444\end{array}$

Means for Oneway Anova

Level Number Mean Std Lower Upper

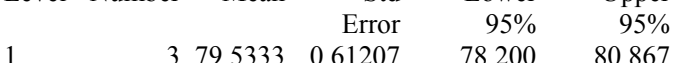

$\begin{array}{llllll}1 & 3 & 79.5333 & 0.61207 & 78.200 & 80.867 \\ 2 & 3 & 79.9333 & 0.61207 & 78.600 & 81.267 \\ 3 & 3 & 79.9000 & 0.61207 & 78.566 & 81.234\end{array}$

\begin{tabular}{llllll}
2 & 3 & 79.9333 & 0.61207 & 78.600 & 81.267 \\
3 & 3 & 79.9000 & 0.61207 & 78.566 & 81.234 \\
\hline
\end{tabular}

$\begin{array}{llllll}4 & 3 & 81.0000 & 0.61207 & 79.666 & 82.334\end{array}$

$\begin{array}{llllll}5 & 3 & 82.4333 & 0.61207 & 81.100 & 83.767 \\ 6 & 3 & 79.6333 & 0.61207 & 78.300 & 80.967\end{array}$

Std Error uses a pooled estimate of error variance

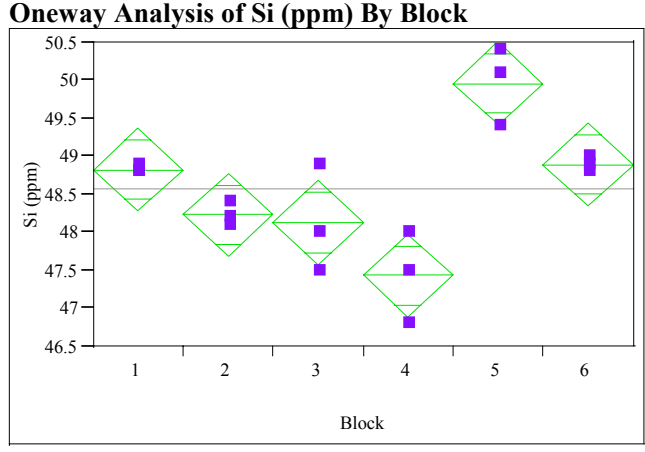

Oneway Anova
Summary of Fit

\begin{tabular}{|c|c|c|c|c|c|c|}
\hline & \multicolumn{3}{|c|}{0.827224} & \\
\hline \multicolumn{3}{|c|}{ Adj Rsquare } & \multicolumn{3}{|c|}{0.755235} & \\
\hline \multicolumn{3}{|c|}{ Root Mean Square Error } & \multicolumn{3}{|c|}{0.440959} & \\
\hline \multicolumn{3}{|c|}{ Mean of Response } & \multicolumn{3}{|c|}{48.58333} & \\
\hline Observat & ions $(\mathrm{o}$ & r Sum Wgts & & 18 & & \\
\hline \multicolumn{7}{|c|}{ Analysis of Variance } \\
\hline Source & DF & $\begin{array}{l}\text { Sum of } \\
\text { Squares }\end{array}$ & \multicolumn{2}{|c|}{$\begin{array}{r}\text { Mean } \\
\text { Square }\end{array}$} & F Ratio & $\mathrm{Pr}$ \\
\hline lock & 5 & 11.17166 & \multicolumn{2}{|c|}{2.23433} & 11.4909 & 0.00 \\
\hline Error & 12 & 2.33333 & \multicolumn{2}{|c|}{0.19444} & & \\
\hline C. Total & 17 & 13.50500 & & & & \\
\hline \multicolumn{7}{|c|}{ Means for Oneway Anova } \\
\hline \multicolumn{2}{|c|}{ Level Number } & Mean & $\begin{array}{r}\text { Stc } \\
\text { Erro }\end{array}$ & & $\begin{array}{l}\text { ower } \\
95 \%\end{array}$ & $\begin{array}{r}\text { Upper } \\
95 \%\end{array}$ \\
\hline 1 & & 48.8333 & $0.2545 \mathrm{c}$ & & 8.279 & 49.388 \\
\hline & & 48.2333 & $0.2545 \mathrm{c}$ & & 7.679 & 48.788 \\
\hline & & 48.1333 & 0.2545 & & 7.579 & 48.688 \\
\hline & 3 & 47.4333 & 0.2545 & & 6.879 & 47.988 \\
\hline 5 & 3 & 49.9667 & 0.2545 & & 9.412 & 50.521 \\
\hline & 3 & 48.9000 & 0.2545 & & 8.345 & 49.455 \\
\hline
\end{tabular}

Std Error uses a pooled estimate of error variance 


\section{Exhibit F3. Measurements of the Multi-Element Solution Standard by ICP Block}

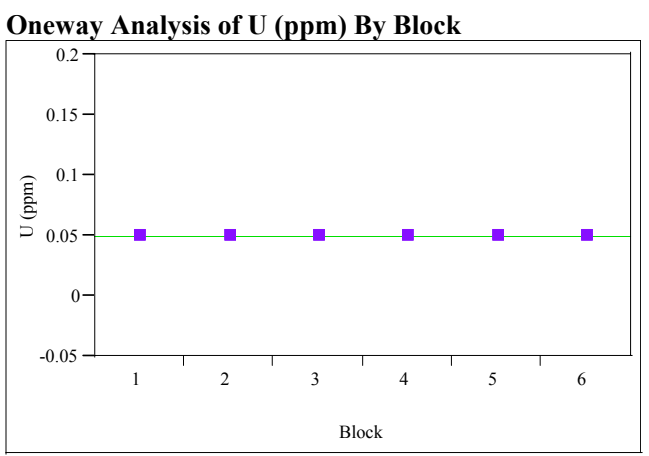

Oneway Anova

Summary of Fit

$\begin{array}{lr}\text { Rsquare } & 0 \\ \text { Adj Rsquare } & -0.41667\end{array}$

Root Mean Square Error $\quad 8.5 \mathrm{e}-18$

Mean of Response

$8.5 \mathrm{e}-18$
0.05

Observations (or Sum Wgts)

Analysis of Variance

Source DF Sum of Mean F Ratio Prob >

$\begin{array}{rrrrrr} & & \text { Squares } & \text { Square } & & \text { F } \\ \text { Block } & 5 & 0 & 0 & 0.0000 & 1.0000\end{array}$

$\begin{array}{lrrr}\text { Block } & 5 & 0 & 0 \\ \text { Error } & 12 & 8.6667 \mathrm{e}-34 & 7.222 \mathrm{e}-35\end{array}$

$\begin{array}{llll}\text { Error } & 12 & 8.6667 \mathrm{e}-34 & 7.222 \mathrm{e}-35\end{array}$

C. Total $17 \quad 8.6667 \mathrm{e}-34$

Means for Oneway Anova

Level Number Mean Std Error Lower Upper

1 - $3 \quad 0.050000 \quad 4.907 \mathrm{e}-18$

$\begin{array}{llll}0.050000 & 4.907 \mathrm{e}-18 & 0.05000 & 0.05000\end{array}$

$\begin{array}{lllll}3 & 0.050000 & 4.907 \mathrm{e}-18 & 0.05000 & 0.05000\end{array}$

$\begin{array}{lllll}3 & 0.050000 & 4.907 \mathrm{e}-18 & 0.05000 & 0.05000\end{array}$

$\begin{array}{lllll}3 & 0.050000 & 4.907 \mathrm{e}-18 & 0.05000 & 0.05000\end{array}$

$\begin{array}{lllll}3 & 0.050000 & 4.907 \mathrm{e}-18 & 0.05000 & 0.05000\end{array}$

$\begin{array}{lllll}3 & 0.050000 & 4.907 \mathrm{e}-18 & 0.05000 & 0.05000\end{array}$

Std Error uses a pooled estimate of error variance 
Exhibit F4. SRNL-ML PCT Measurements by VIS Study Glass and Standards
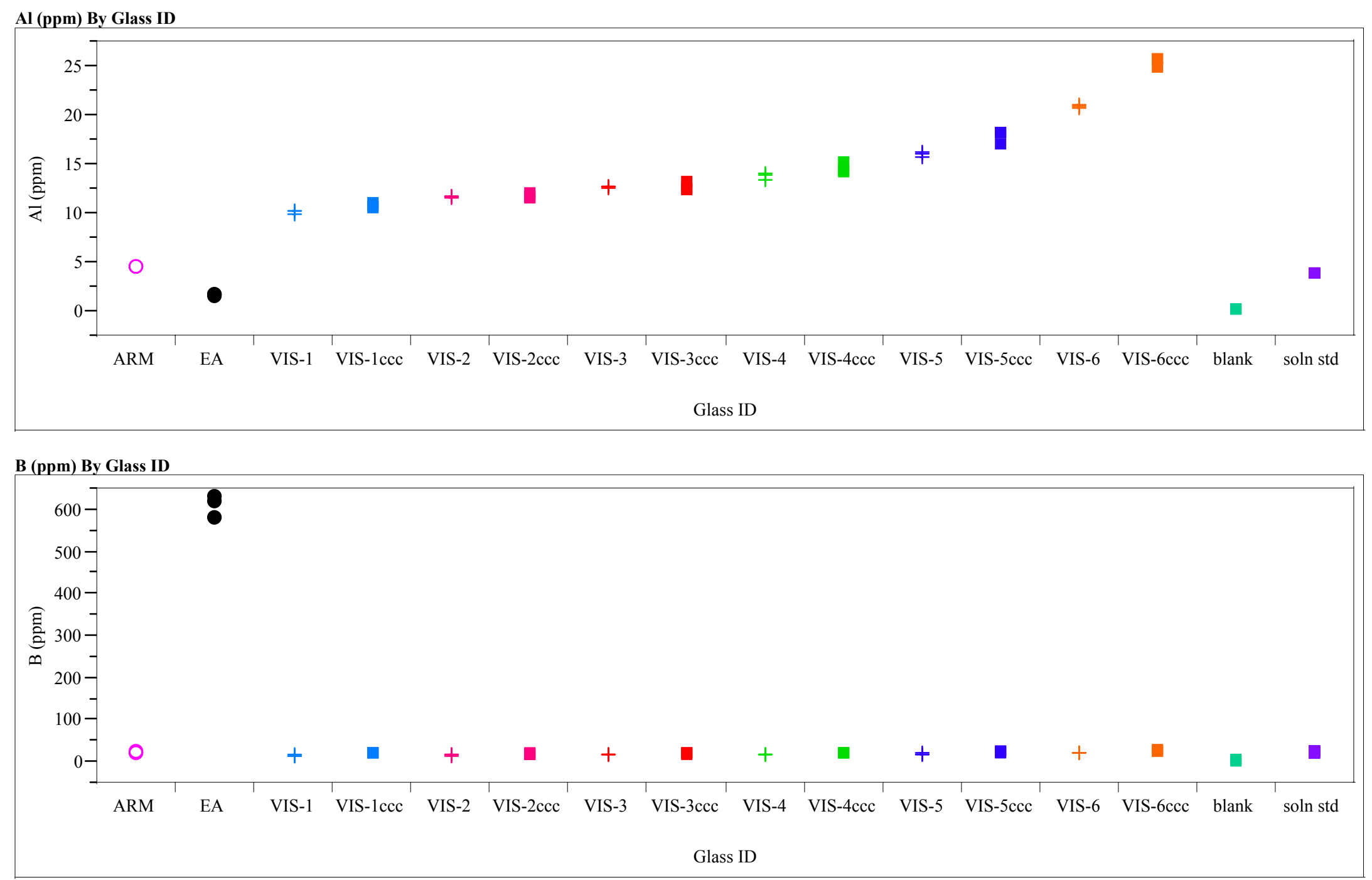
Exhibit F4. SRNL-ML PCT Measurements by VIS Study Glass and Standards
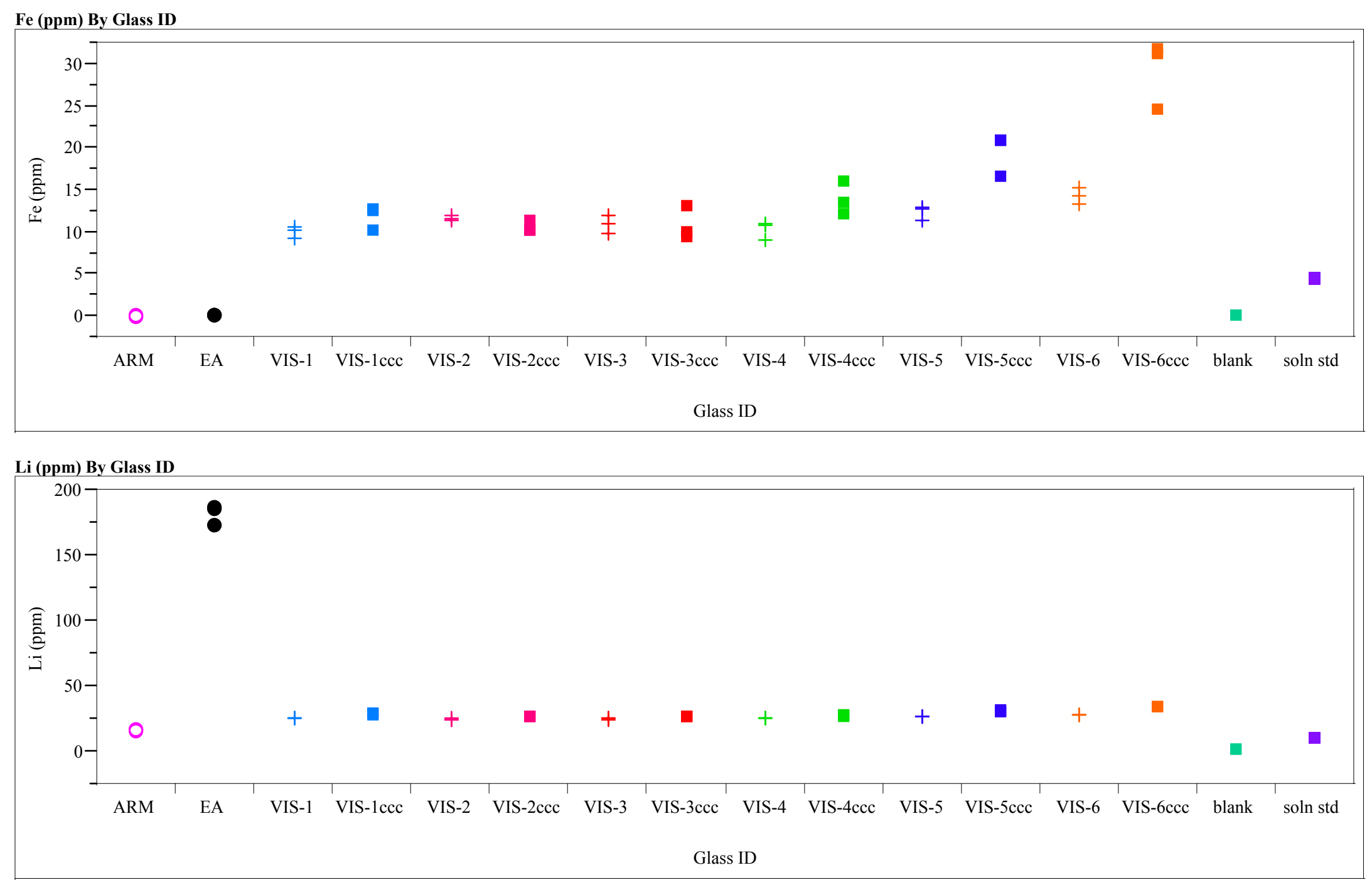
Exhibit F4. SRNL-ML PCT Measurements by VIS Study Glass and Standards
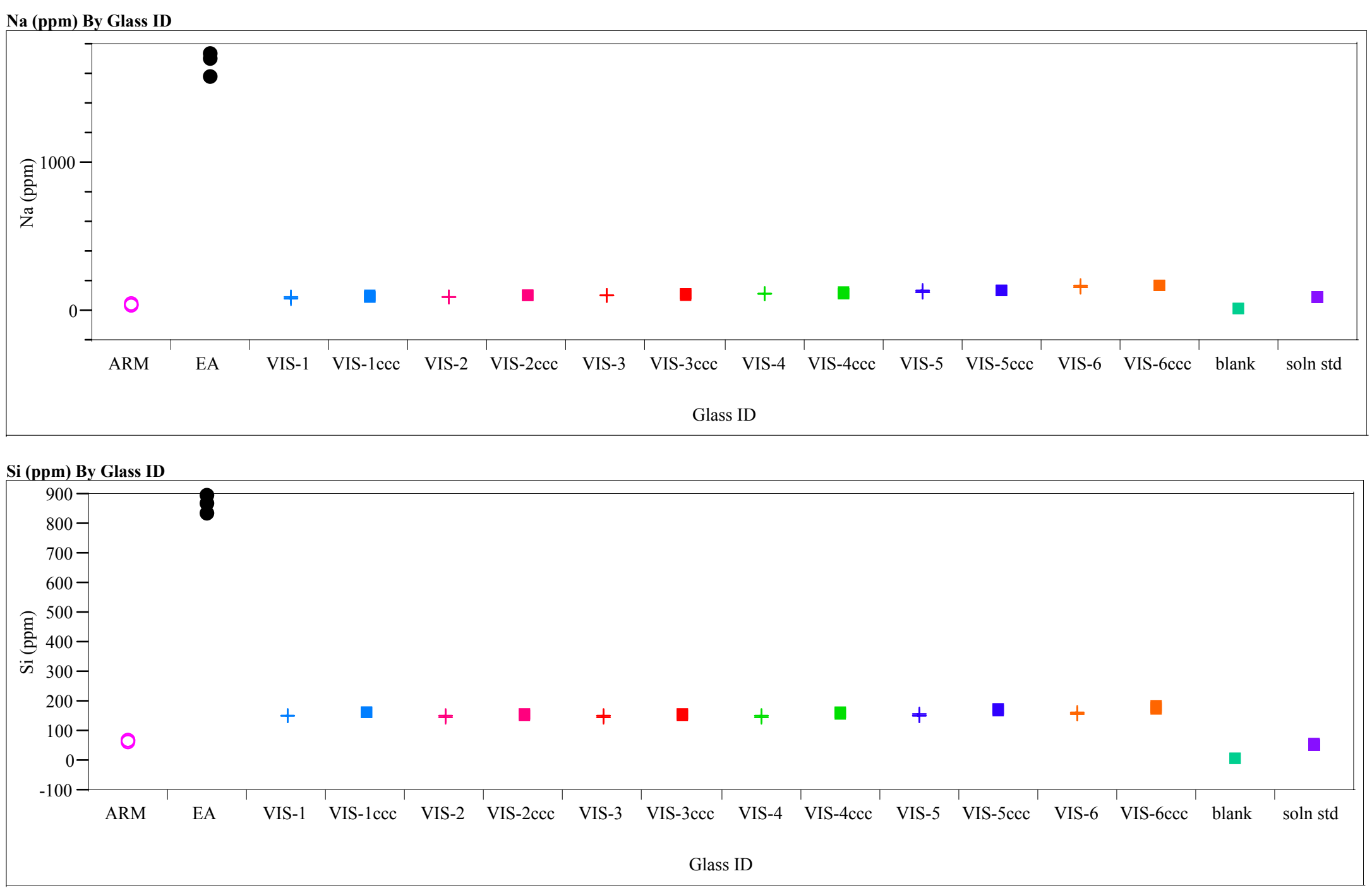
Exhibit F4. SRNL-ML PCT Measurements by VIS Study Glass and Standards

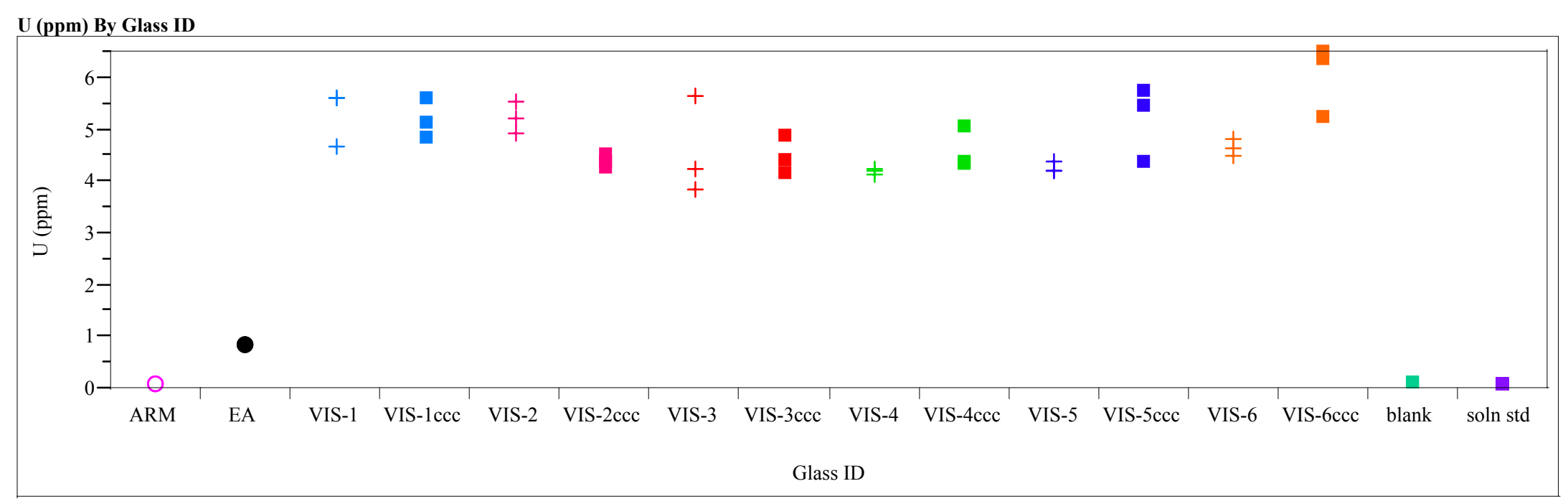


Exhibit F5. SRNL-ML PCT Measurements by VIS Study, ARM-1, and Solution Standards (EA and blanks Excluded)

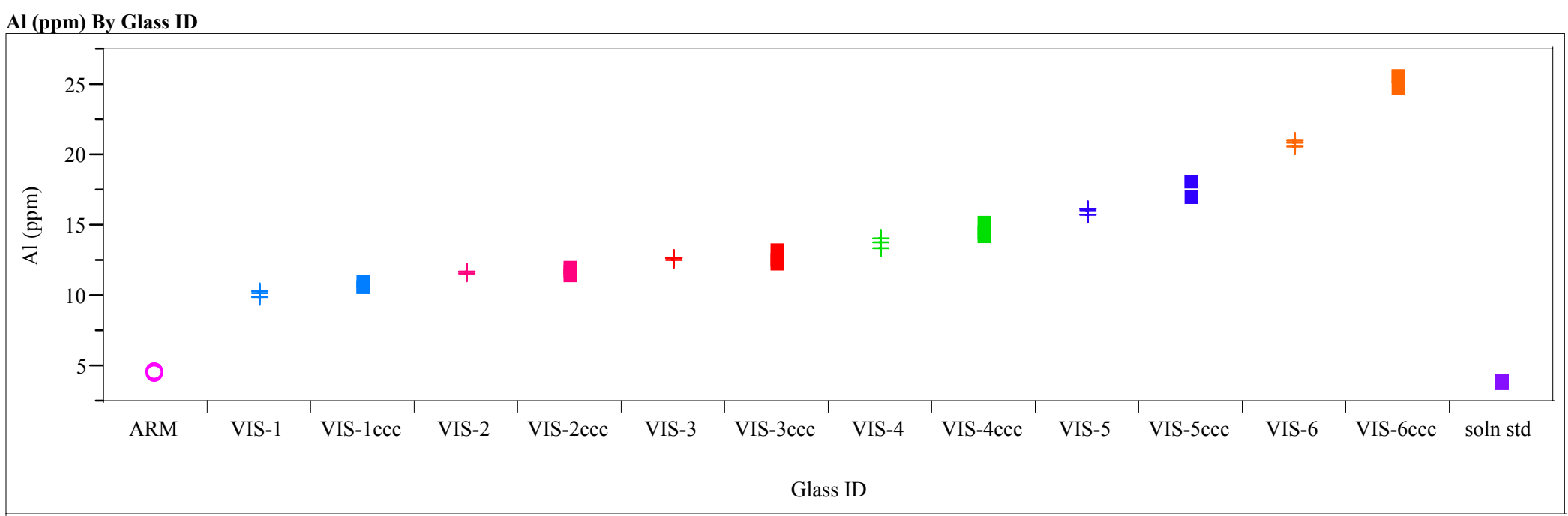

B (ppm) By Glass ID

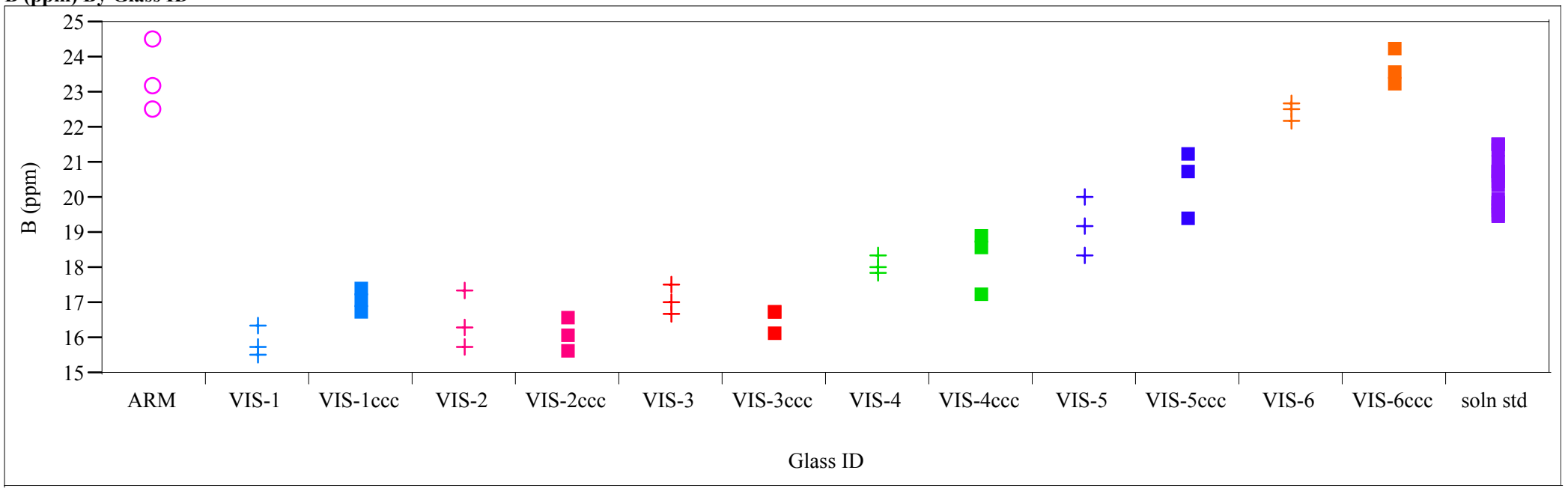


Exhibit F5. SRNL-ML PCT Measurements by VIS Study, ARM-1, and Solution Standards (EA and blanks Excluded)
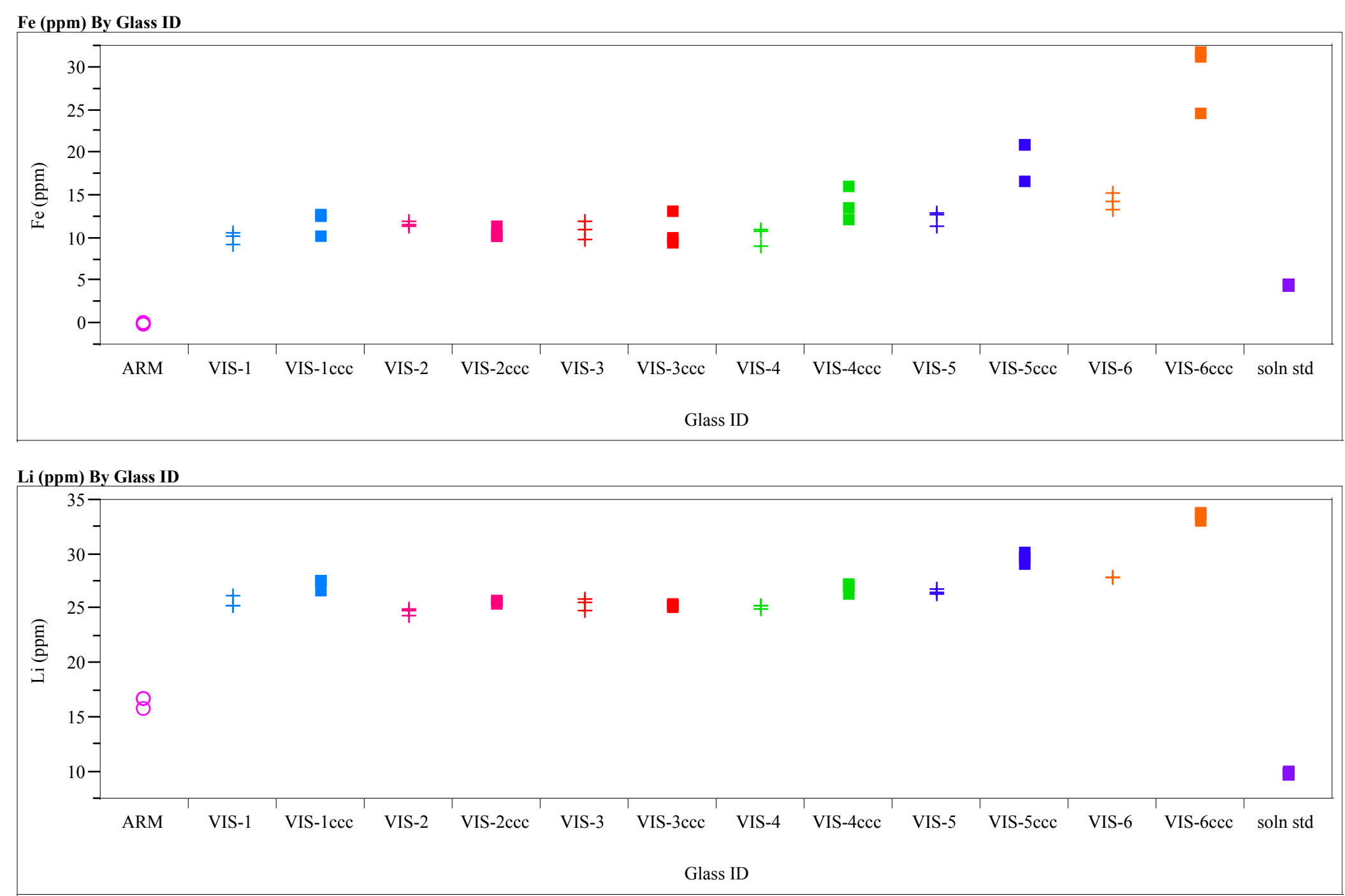
Exhibit F5. SRNL-ML PCT Measurements by VIS Study, ARM-1, and Solution Standards (EA and blanks Excluded)
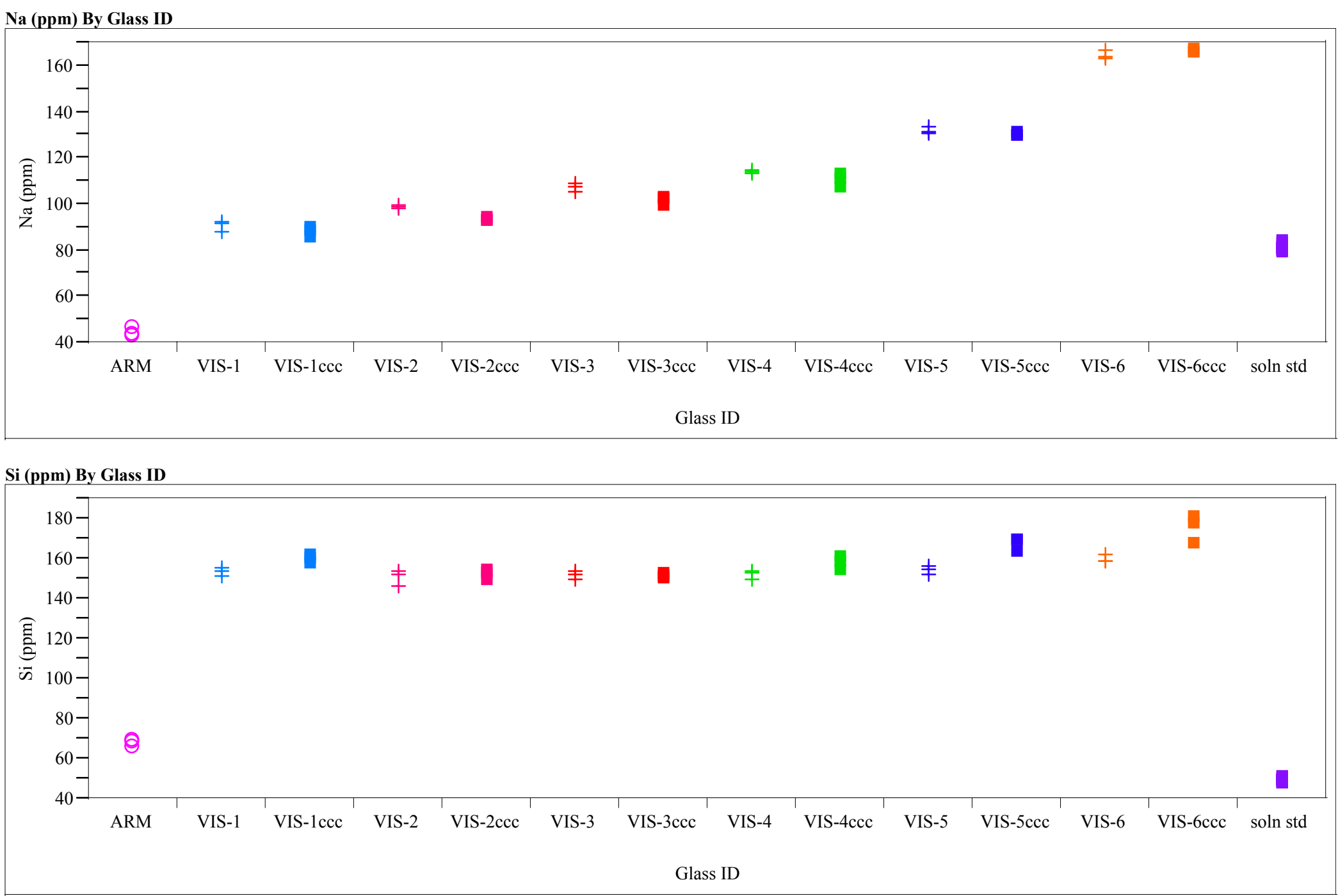
Exhibit F5. SRNL-ML PCT Measurements by VIS Study, ARM-1, and Solution Standards (EA and blanks Excluded)

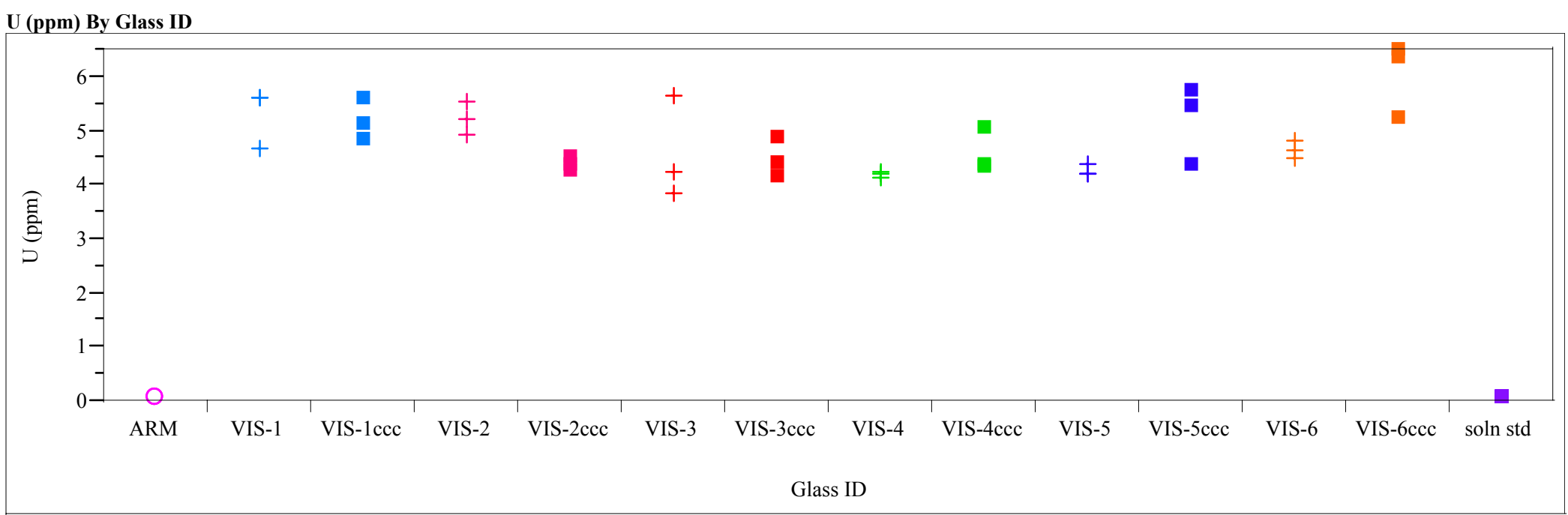




\section{Exhibit F6. Effects of Heat Treatment on PCT Response over the VIS Study Glasses}

(Paired t-test Comparisons)

\section{Matched Pairs}

Difference: Mean(AI (ppm)) quenched-Mean(AI (ppm)) ccc

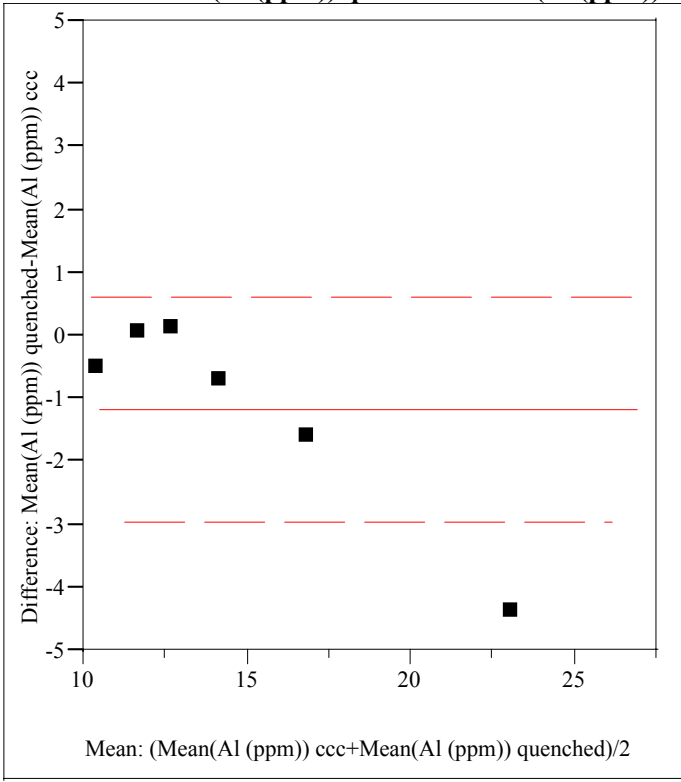

$\operatorname{Mean}(\mathrm{Al}(\mathrm{ppm}))$ quenched $\operatorname{Mean}(\mathrm{Al}(\mathrm{ppm})) \mathrm{ccc}$

Mean Difference

Std Error

Upper $95 \%$

Lower95\%

$\mathrm{N}$

Correlation
Difference: Mean(B (ppm)) quenched-Mean(B (ppm)) ccc

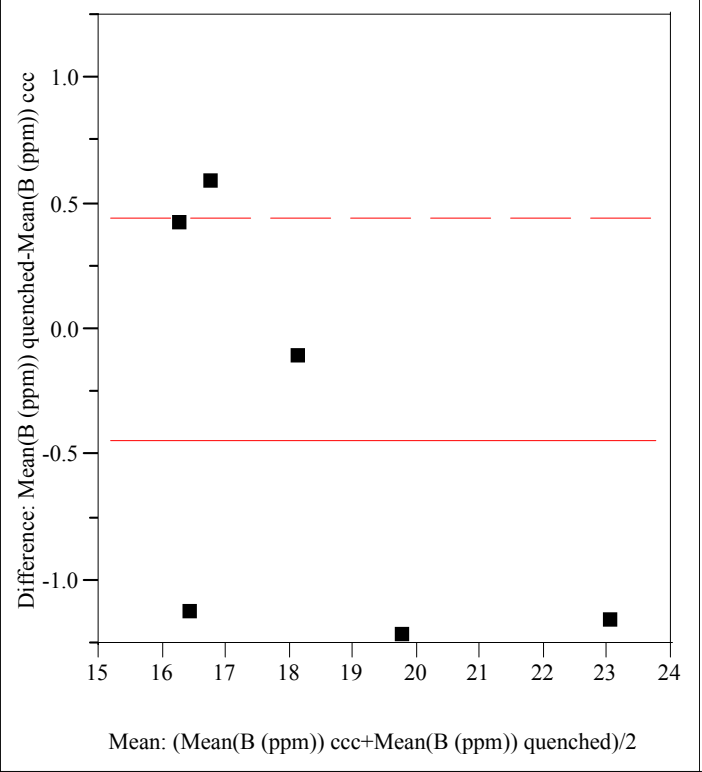

Mean(B (ppm)) quenched

$\operatorname{Mean}(\mathrm{B}(\mathrm{ppm})) \mathrm{ccc}$

Mean Difference

Std Error

Upper $95 \%$

Lower95\%

Correlation

$\begin{array}{rlr}18.1763 & \text { t-Ratio } & -1.28313 \\ 18.6152 & \text { DF } & 5 \\ -0.4389 & \text { Prob }>|t| & 0.2557 \\ 0.34205 & \text { Prob }>\text { t } & 0.8721 \\ 0.44038 & \text { Prob }<\mathrm{t} & 0.1279 \\ -1.3182 & & \\ 6 & & \\ 0.96782 & & \end{array}$

Difference: Mean(Fe (ppm)) quenched-Mean(Fe (ppm)) ccc

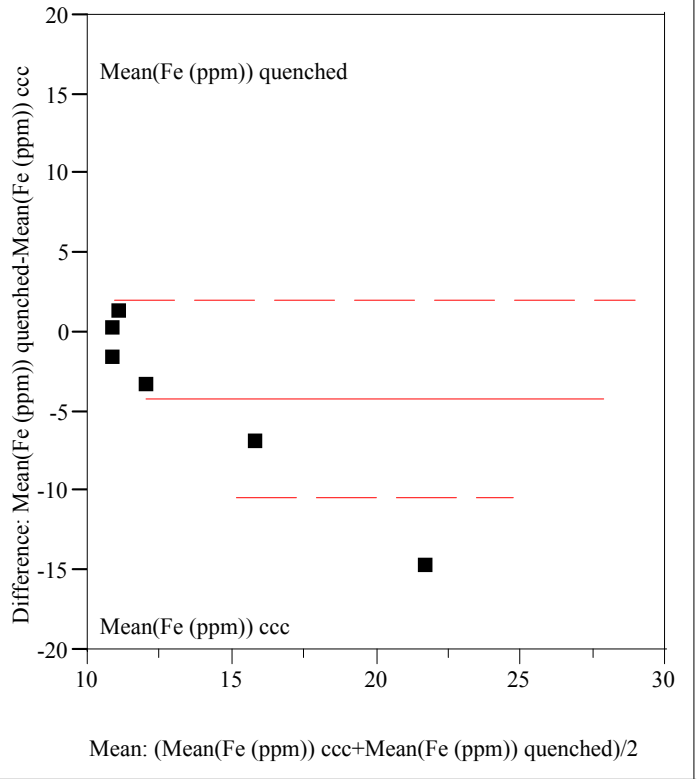

Mean(Fe (ppm)) quenched

15.7948

t-Ratio

$-1.74241$

Fe (ppm))

$-4.2066$

DF

0.1419

Std Error

1.9994

0.9290

Upper95\%

Prob $<$ t

0.0710

$-10.413$

$\mathrm{N}$

0.88248 
Exhibit F6. Effects of Heat Treatment on PCT Response over the VIS Study Glasses (continued)

(Paired t-test Comparisons)

$$
\text { (continued) }
$$

Difference:

Mean(Li (ppm)) quenched-Mean(Li (ppm)) ccc

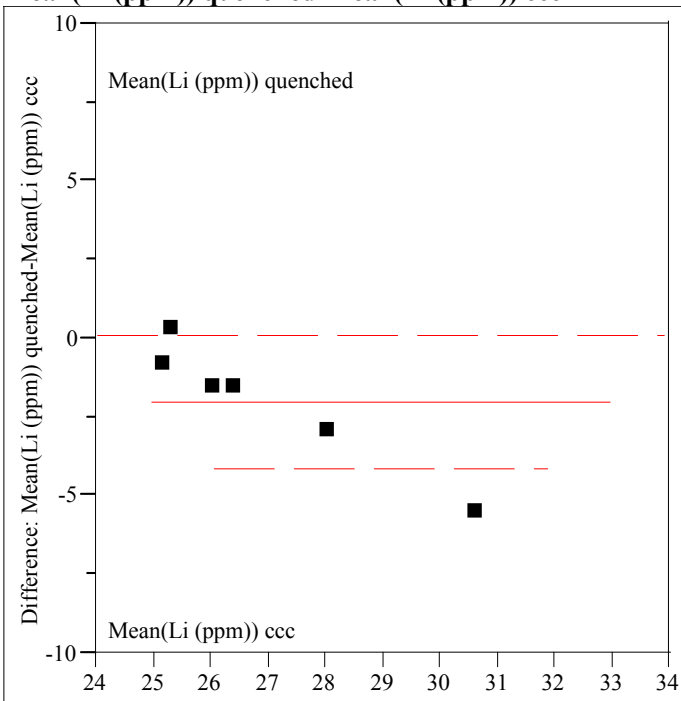

Mean: (Mean(Li (ppm)) ccc+Mean(Li (ppm)) quenched)/2

Mean(Li (ppm)) quenched $\operatorname{Mean}(\mathrm{Li}(\mathrm{ppm})) \mathrm{ccc}$

Mean Difference

Std Error

Upper95\%

Correlation

$\begin{array}{rlr}25.8987 & \text { t-Ratio } & -2.45461 \\ 27.9265 & \text { DF } & 5 \\ -2.0278 & \text { Prob }>|t| & 0.0576 \\ 0.82613 & \text { Prob }>\text { t } & 0.9712 \\ 0.09581 & \text { Prob }<t & 0.0288 \\ -4.1514 & & \\ 6 & & \\ 0.96205 & & \end{array}$

Difference:

Mean(Na (ppm)) quenched-Mean(Na (ppm)) ccc

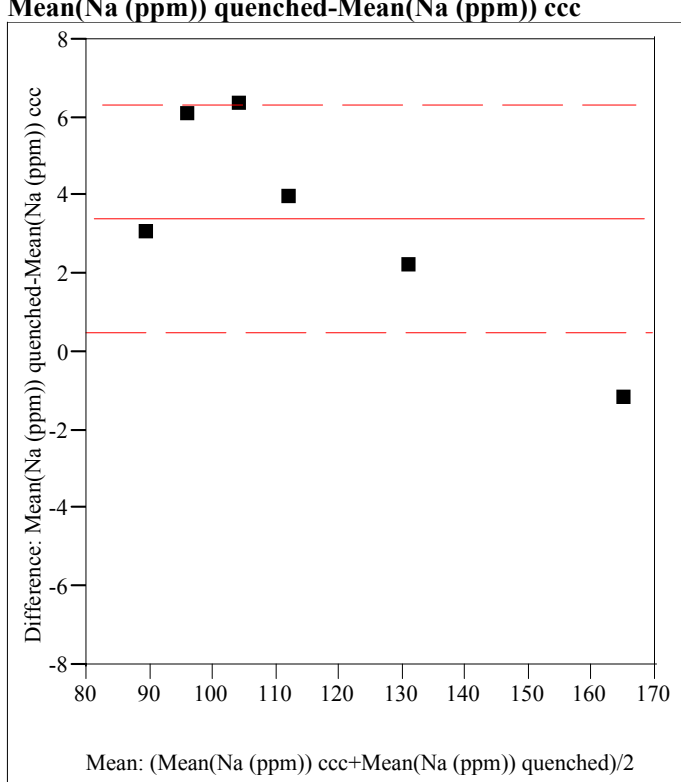

Mean(Na (ppm)) quenched

117.91

Mean Difference

Mean Difference

Std Error

Upper95\%

Lower95\%

Correlation
Difference:

$\operatorname{Mean}(\mathrm{Si}(\mathrm{ppm}))$ quenched-Mean(Si (ppm)) ccc

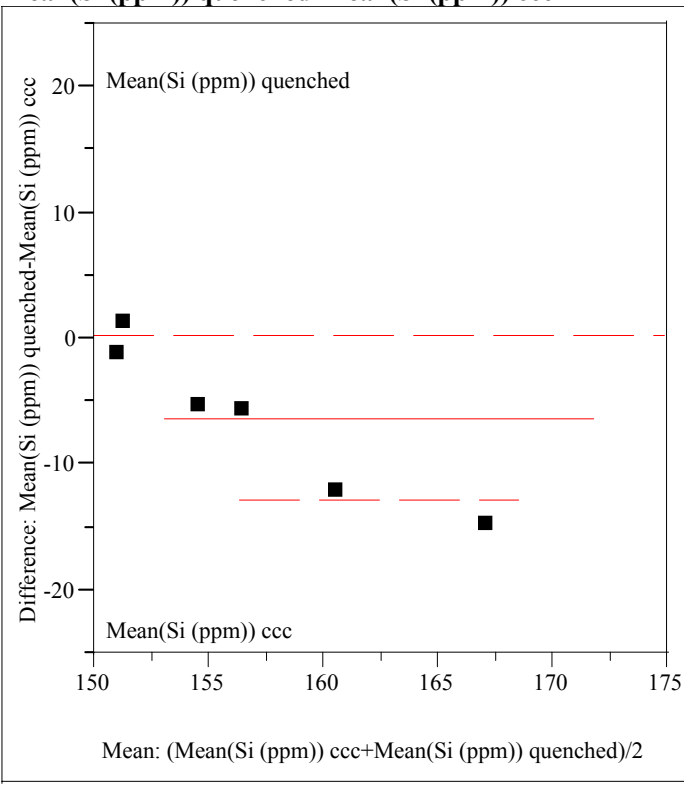

$\operatorname{Mean}(\mathrm{Si}(\mathrm{ppm}))$ quenched $\operatorname{Mean}(\mathrm{Si}$ (ppm)) ccc

Mean Difference

Std Error

Upper $95 \%$

Prob $>|\mathrm{t}| \quad 0.0296$

$\begin{array}{ll}\text { Prob }>\mathrm{t} & 0.0148 \\ \text { Prob }<\mathrm{t} & 0.9852\end{array}$

Lower95\%

Correlation

$\begin{array}{rlr}153.605 & \mathrm{t}-\text { Ratio } & -2.50487 \\ 159.929 & \text { DF } & 5 \\ -6.3242 & \text { Prob }>|\mathrm{t}| & 0.0542 \\ 2.52476 & \text { Prob }>\mathrm{t} & 0.9729 \\ 0.1659 & \text { Prob }<\mathrm{t} & 0.0271 \\ -12.814 & & \\ 6 & & \\ 0.93814 & & \end{array}$

0.93814 
Exhibit F6. Effects of Heat Treatment on PCT Response over the VIS Study Glasses (continued) (Paired t-test Comparisons) (continued)

Difference: Mean(U (ppm)) quenched-Mean(U (ppm)) ccc

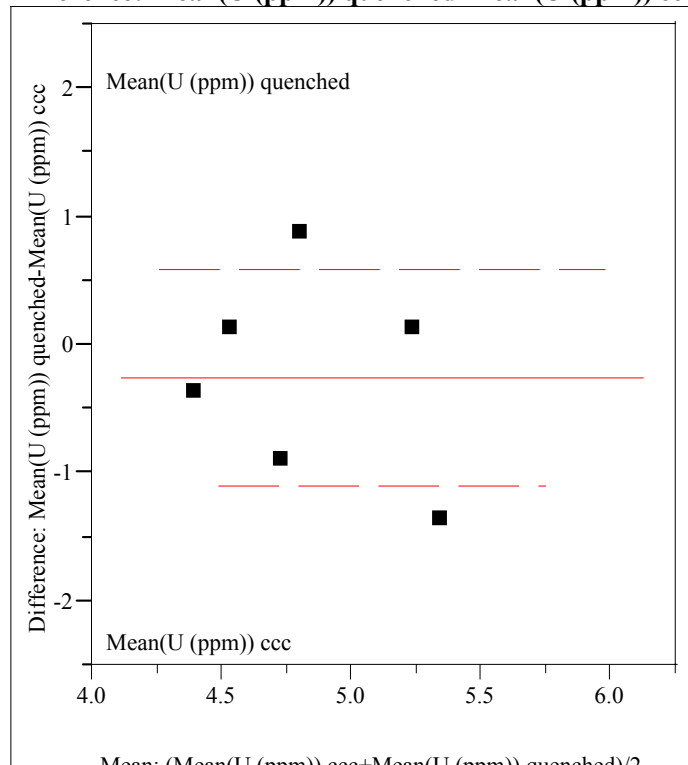

Mean: (Mean(U (ppm)) ccc+Mean(U (ppm)) quenched)/2

Mean(U (ppm)) quenched $\operatorname{Mean}(\mathrm{U}(\mathrm{ppm})) \mathrm{ccc}$ Mean Difference

Std Error

Upper95\%

Lower95\%

Correlation

$\begin{array}{lr}\text { t-Ratio } & -0.78393 \\ \text { DF } & 5 \\ \text { Prob }>|t| & 0.4686 \\ \text { Prob }>\text { t } & 0.7657 \\ \text { Prob }<\text { t } & 0.2343\end{array}$

$\begin{array}{ll}\text { Prob }>t & 0.7657\end{array}$

0.5845

$-1.0975$

6
-0.0573 


\section{Exhibit F7. Correlations and Scatter Plots of Normalized PCTs by Compositional View for the VIS Study Glasses}

\section{Comp View=All}

$\begin{array}{lrrrr} & \log \mathrm{NL}[\mathrm{B}(\mathrm{g} / \mathrm{L})] & \log \mathrm{NL}[\mathrm{Li}(\mathrm{g} / \mathrm{L})] & \log \mathrm{NL}[\mathrm{Na}(\mathrm{g} / \mathrm{L})] & \log \mathrm{NL}[\mathrm{Si}(\mathrm{g} / \mathrm{L})] \\ \log \mathrm{NL}[\mathrm{B}(\mathrm{g} / \mathrm{L})] & 1.0000 & 0.9529 & 0.9749 & 0.9673 \\ \log \mathrm{NL}[\mathrm{Li}(\mathrm{g} / \mathrm{L})] & 0.9529 & 1.0000 & 0.9152 & 0.9763 \\ \log \mathrm{NL}[\mathrm{Na}(\mathrm{g} / \mathrm{L})] & 0.9749 & 0.9152 & 1.0000 & 0.9410 \\ \log \mathrm{NL}[\mathrm{Si}(\mathrm{g} / \mathrm{L})] & 0.9673 & 0.9763 & 0.9410 & 1.0000\end{array}$

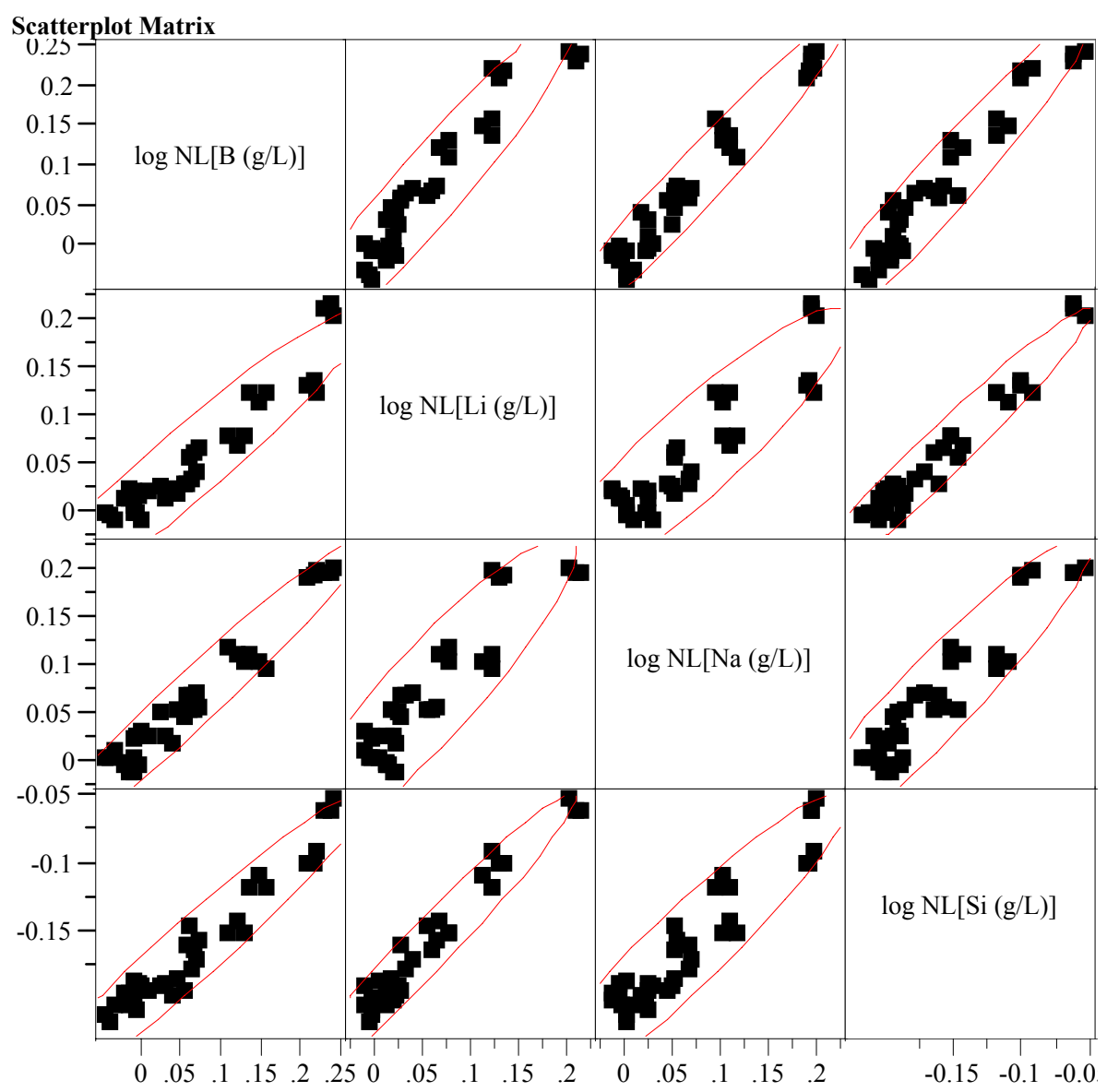




\section{Exhibit F7. Correlations and Scatter Plots of Normalized PCTs by Compositional View for the VIS Study Glasses (continued)}

\section{Comp View $=$ measured}

$\begin{array}{lrrrr}\text { Correlations } & & & & \\ & \log \mathrm{NL}[\mathrm{B}(\mathrm{g} / \mathrm{L})] & \log \mathrm{NL}[\mathrm{Li}(\mathrm{g} / \mathrm{L})] & \log \mathrm{NL}[\mathrm{Na}(\mathrm{g} / \mathrm{L})] & \log \mathrm{NL}[\mathrm{Si}(\mathrm{g} / \mathrm{L})] \\ \log \mathrm{NL}[\mathrm{B}(\mathrm{g} / \mathrm{L})] & 1.0000 & 0.9458 & 0.9649 & 0.9554 \\ \log \mathrm{NL}[\mathrm{Li}(\mathrm{g} / \mathrm{L})] & 0.9458 & 1.0000 & 0.9173 & 0.9898 \\ \log \mathrm{NL}[\mathrm{Na}(\mathrm{g} / \mathrm{L})] & 0.9649 & 0.9173 & 1.0000 & 0.9439 \\ \log \mathrm{NL}[\mathrm{Si}(\mathrm{g} / \mathrm{L})] & 0.9554 & 0.9898 & 0.9439 & 1.0000\end{array}$

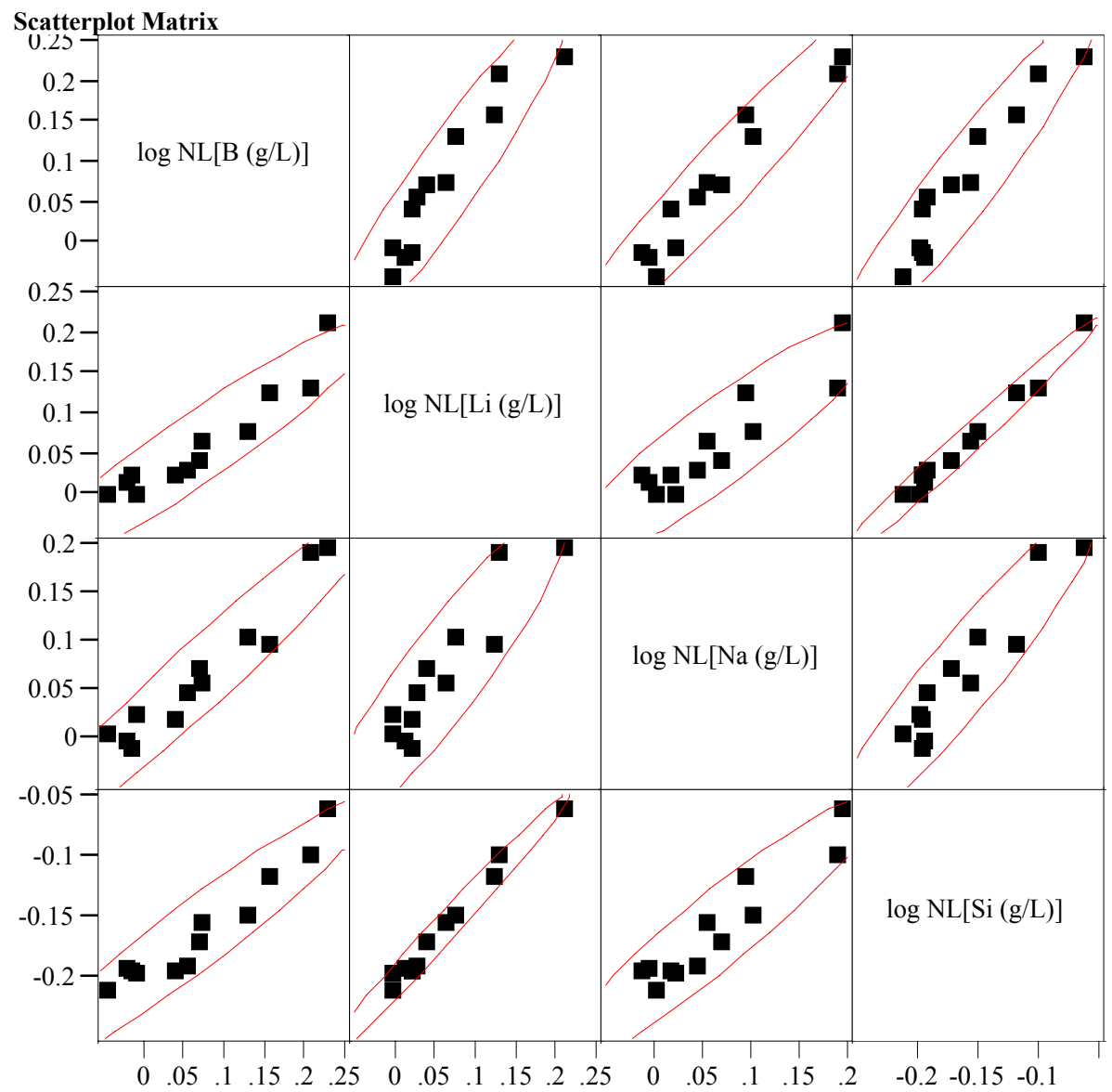




\section{Exhibit F7. Correlations and Scatter Plots of Normalized PCTs by Compositional View for the VIS Study Glasses (continued)}

Comp View $=$ measured bc

$\begin{array}{lrrrr}\text { Correlations } & & & & \\ & \log \mathrm{NL}[\mathrm{B}(\mathrm{g} / \mathrm{L})] & \log \mathrm{NL}[\mathrm{Li}(\mathrm{g} / \mathrm{L})] & \log \mathrm{NL}[\mathrm{Na}(\mathrm{g} / \mathrm{L})] & \log \mathrm{NL}[\mathrm{Si}(\mathrm{g} / \mathrm{L})] \\ \log \mathrm{NL}[\mathrm{B}(\mathrm{g} / \mathrm{L})] & 1.0000 & 0.9592 & 0.9803 & 0.9721 \\ \log \mathrm{NL}[\mathrm{Li}(\mathrm{g} / \mathrm{L})] & 0.9592 & 1.0000 & 0.9186 & 0.9887 \\ \log \mathrm{NL}[\mathrm{Na}(\mathrm{g} / \mathrm{L})] & 0.9803 & 0.9186 & 1.0000 & 0.9411 \\ \log \mathrm{NL}[\mathrm{Si}(\mathrm{g} / \mathrm{L})] & 0.9721 & 0.9887 & 0.9411 & 1.0000\end{array}$

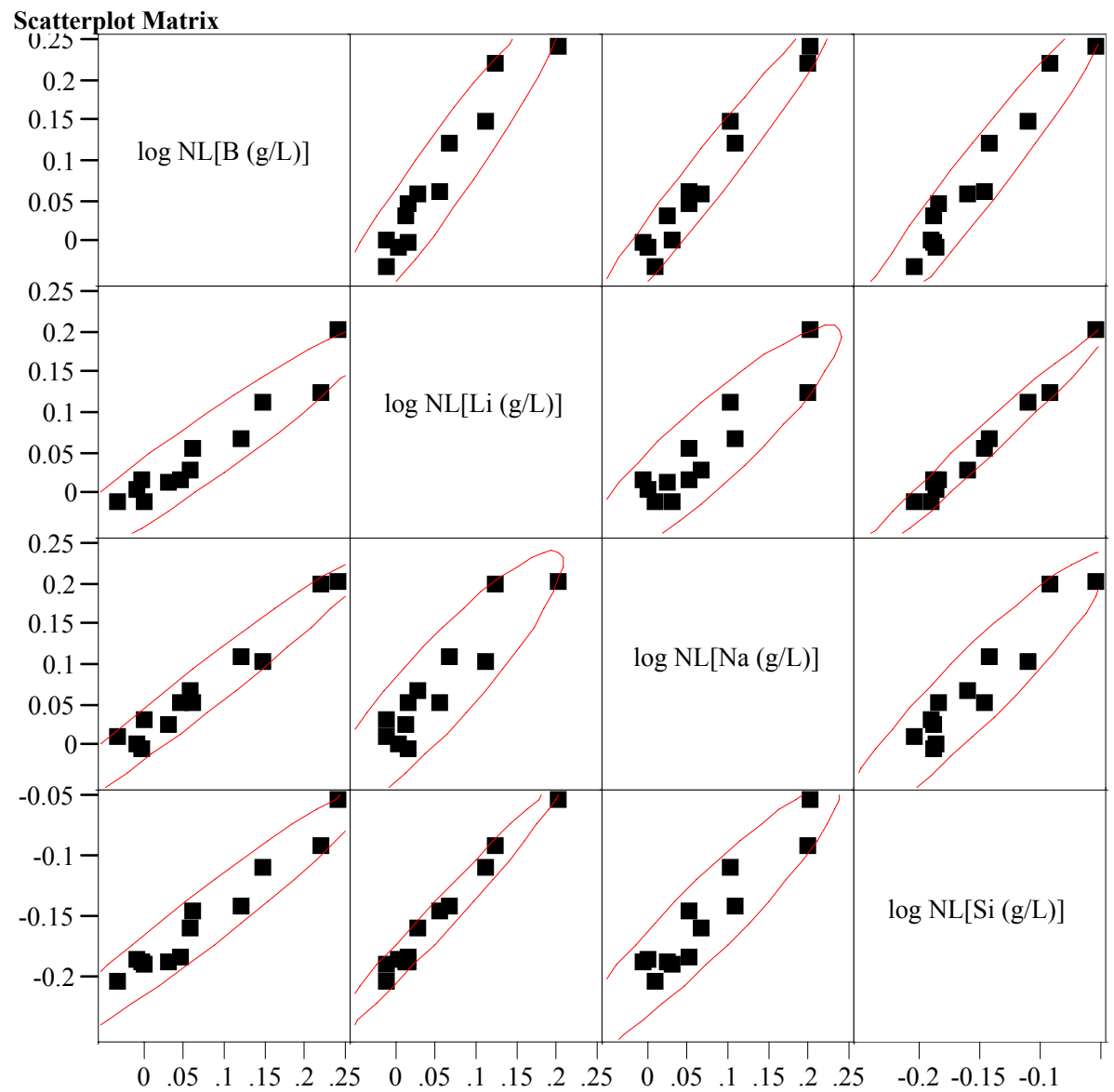




\section{Exhibit F7. Correlations and Scatter Plots of Normalized PCTs by Compositional View for the VIS Study Glasses (continued)}

\section{Comp View $=$ targeted}

Correlations
$\log \mathrm{NL}[\mathrm{B}(\mathrm{g} / \mathrm{L})]$
$\log \mathrm{NL}[\mathrm{Li}(\mathrm{g} / \mathrm{L})]$
$\log \mathrm{NL}[\mathrm{Na}(\mathrm{g} / \mathrm{L})]$
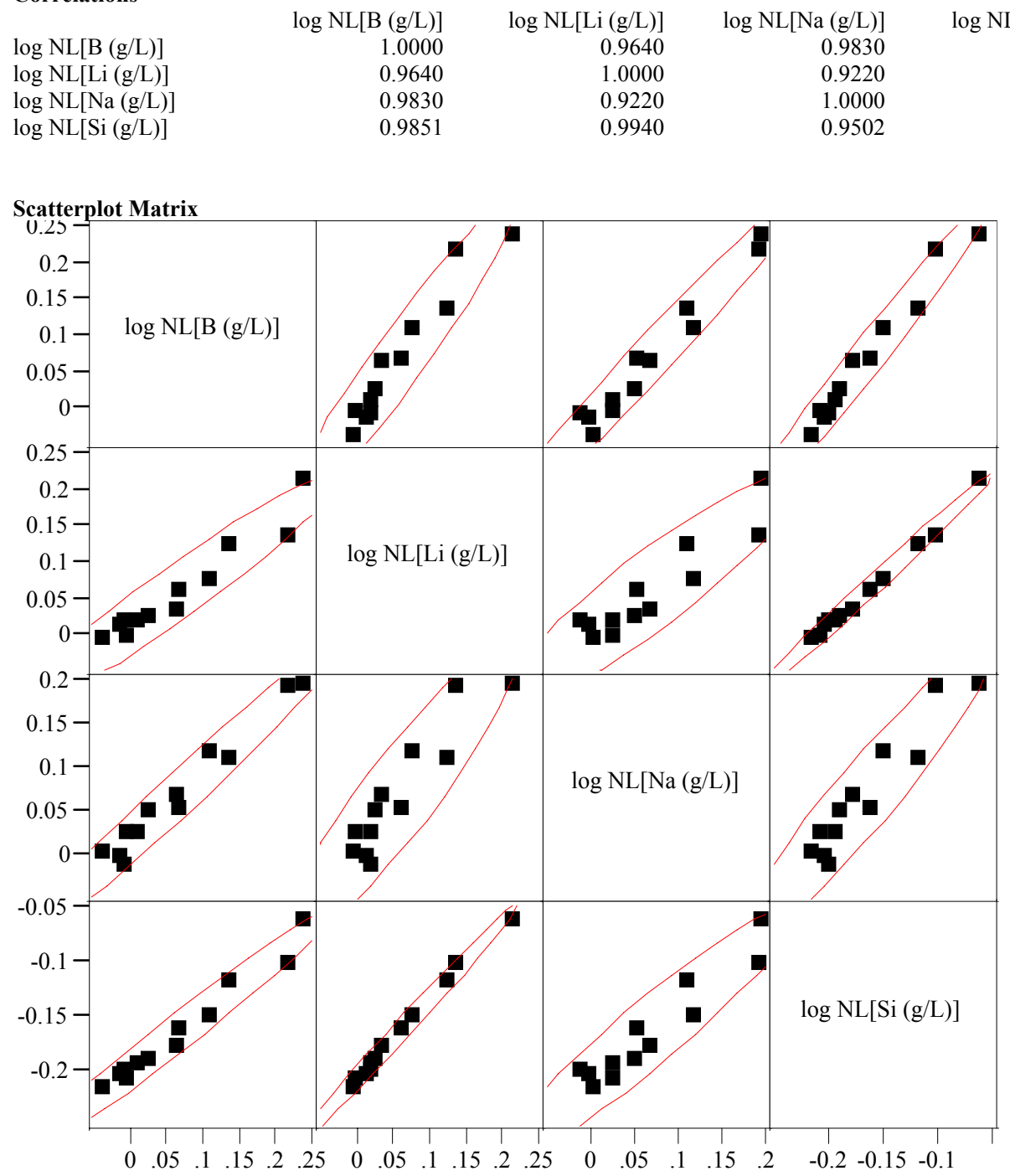
Exhibit F8. del Gp $\left(\Delta G_{p}\right)$ Predictions versus Common Logarithm Normalized Leachate $(\log \mathrm{NL}[]$.$) for \mathrm{B}, \mathrm{Li}$, Na, and Si by Compositional View for VIS Glasses

All Data

Bivariate Fit of $\log$ NL[B (g/L)] By del Gp

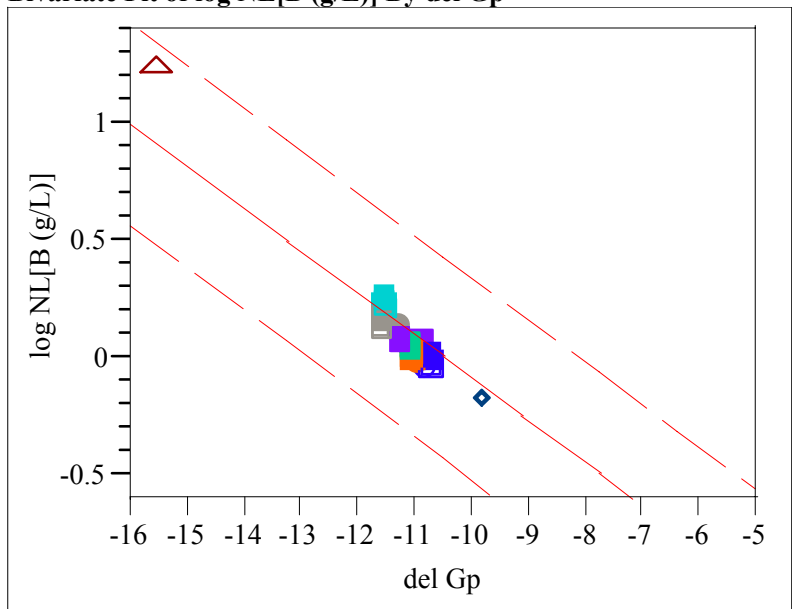

Bivariate Fit of $\log \mathrm{NL}[\mathrm{Li}(\mathrm{g} / \mathrm{L})]$ By del Gp

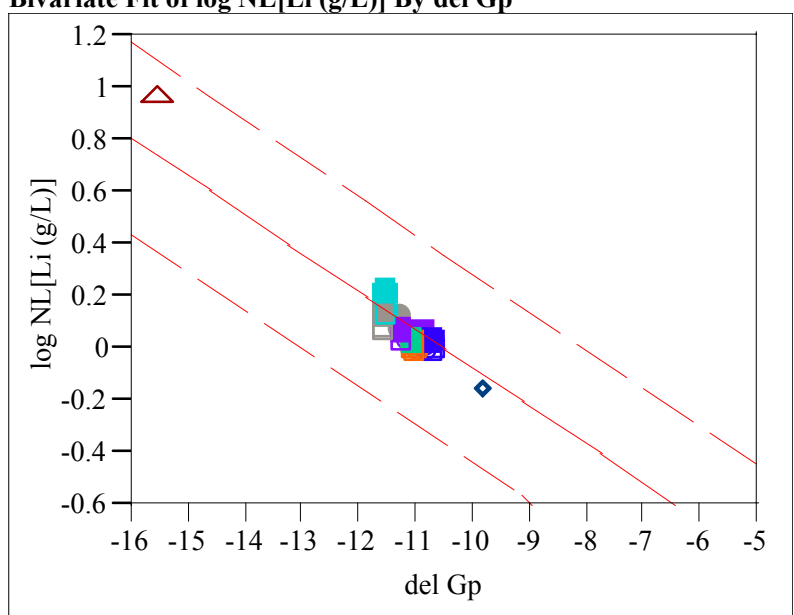

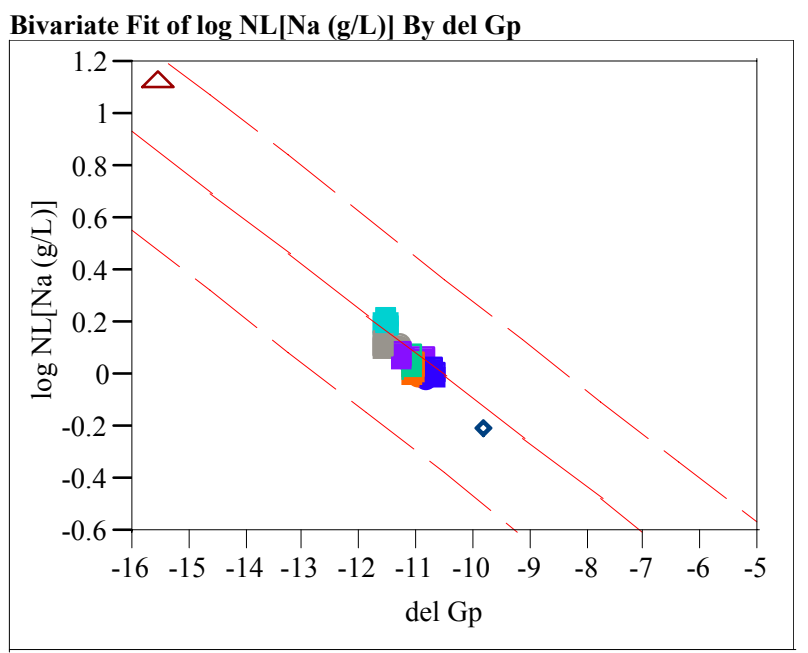

Bivariate Fit of log NL[Si (g/L)] By del Gp

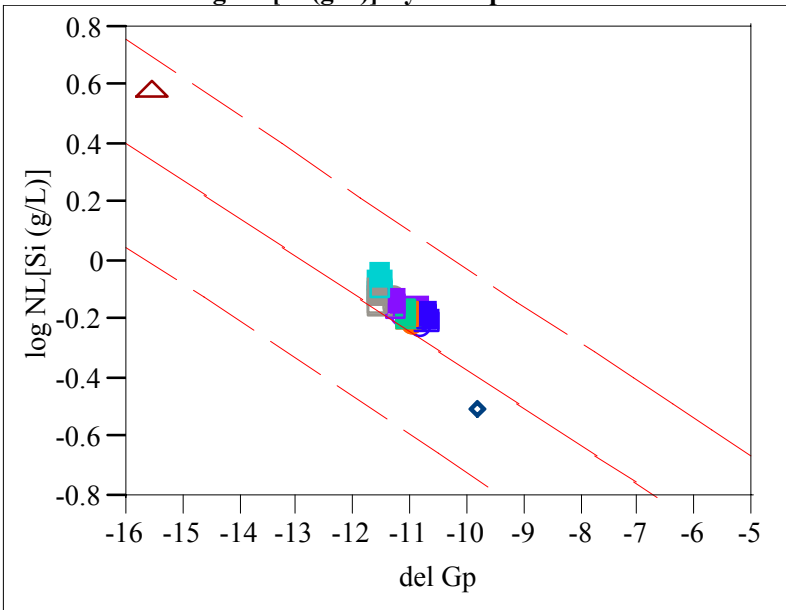


Exhibit F8. del Gp $\left(\Delta G_{p}\right)$ Predictions versus Common Logarithm Normalized Leachate $(\log \mathrm{NL}[]$.$) for \mathrm{B}$, Li, Na, and Si by Compositional View for VIS Glasses (continued)

\section{Measured Data}

Bivariate Fit of $\log$ NL[B (g/L)] By del Gp

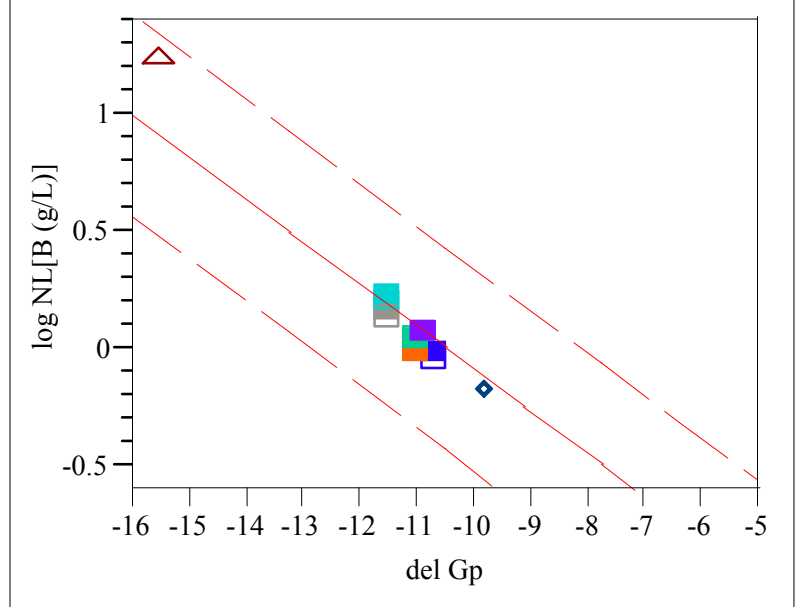

Bivariate Fit of $\log \mathrm{NL}[\mathrm{Li}(\mathrm{g} / \mathrm{L})]$ By del Gp

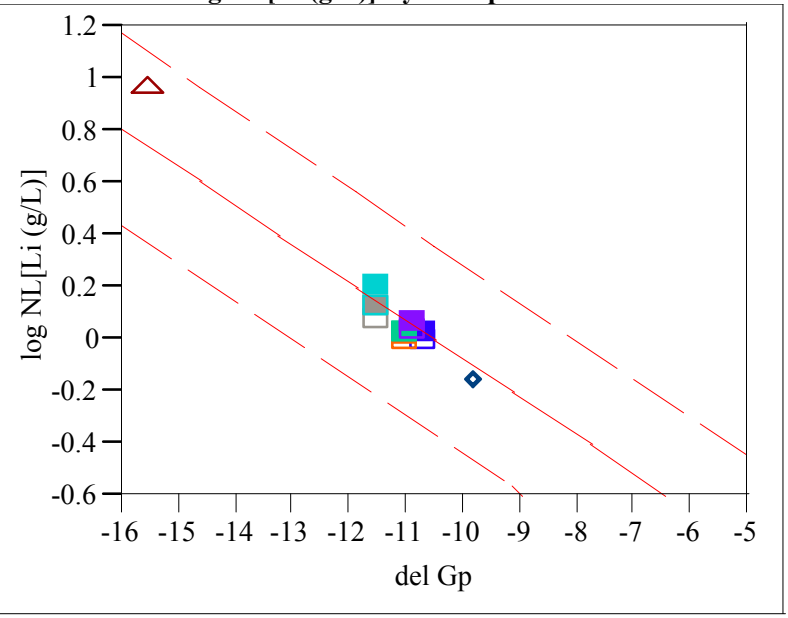

Bivariate Fit of $\log \mathrm{NL}[\mathrm{Na}(\mathrm{g} / \mathrm{L})]$ By del Gp

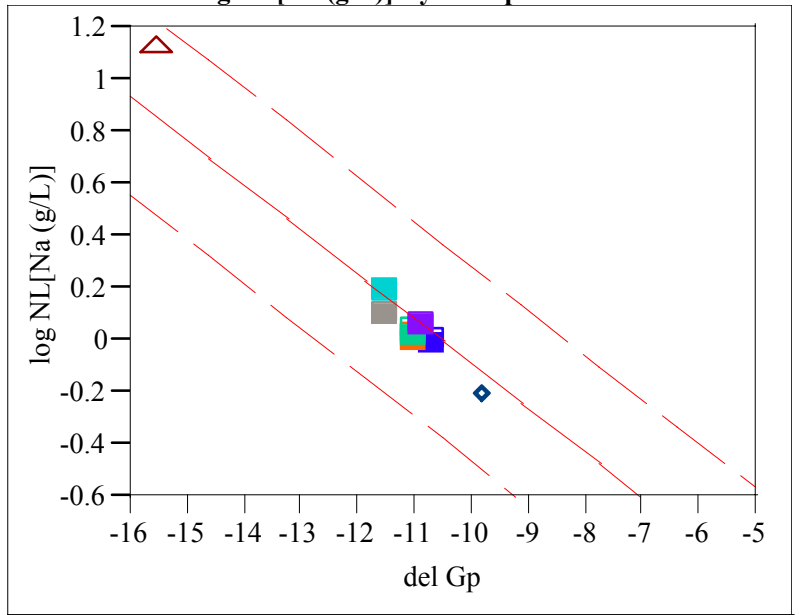

Bivariate Fit of $\log \mathrm{NL}[\mathrm{Si}(\mathrm{g} / \mathrm{L})]$ By del Gp

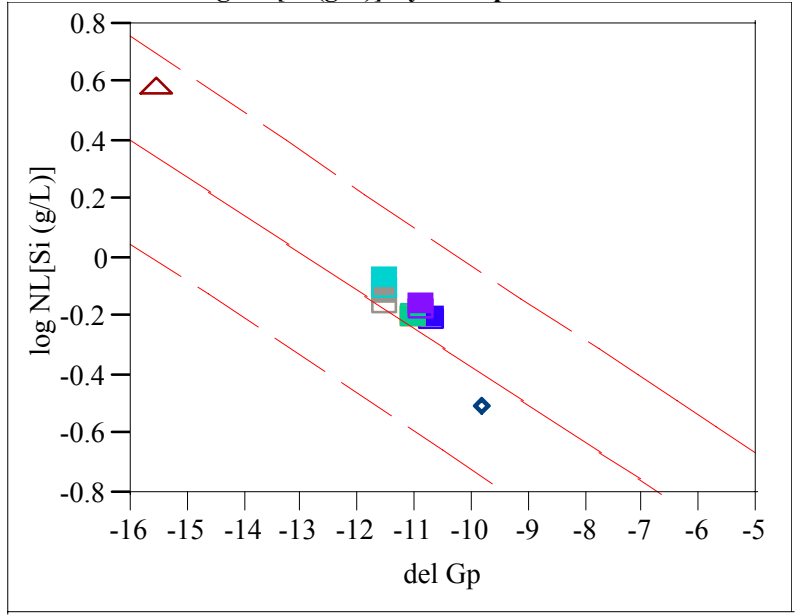


Exhibit F8. del $G p\left(\Delta G_{p}\right)$ Predictions versus Common Logarithm Normalized Leachate (log NL[.]) for B, Li, Na, and Si by Compositional View for VIS Glasses (continued)

\section{Measured bc Data}

Bivariate Fit of $\log$ NL[B (g/L)] By del Gp

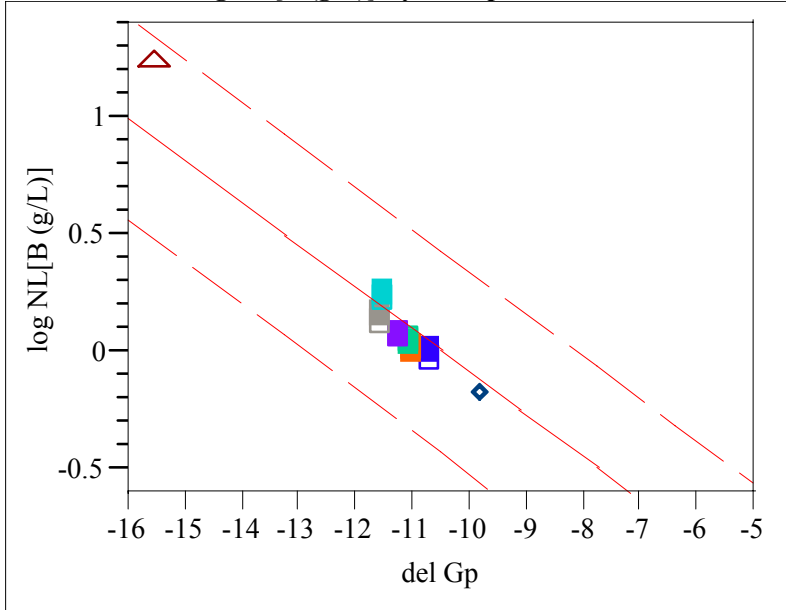

Bivariate Fit of $\log \mathrm{NL}[\mathrm{Li}(\mathrm{g} / \mathrm{L})]$ By del Gp

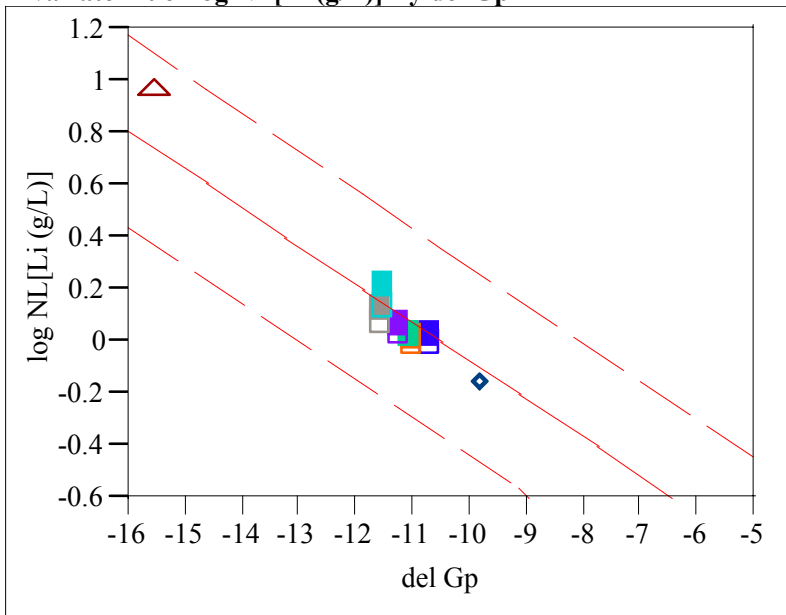

Bivariate Fit of $\log$ NL[Na (g/L)] By del Gp

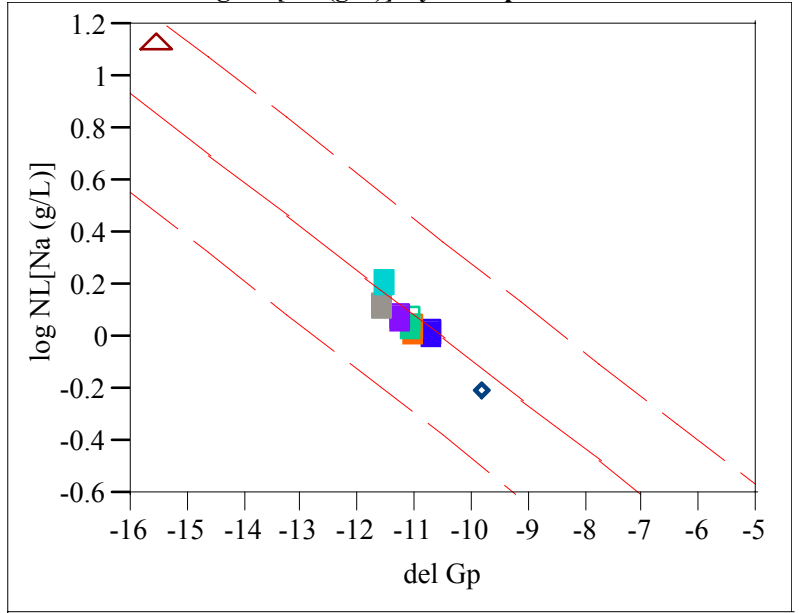

Bivariate Fit of $\log \mathrm{NL}[\mathrm{Si}(\mathrm{g} / \mathrm{L})]$ By del Gp

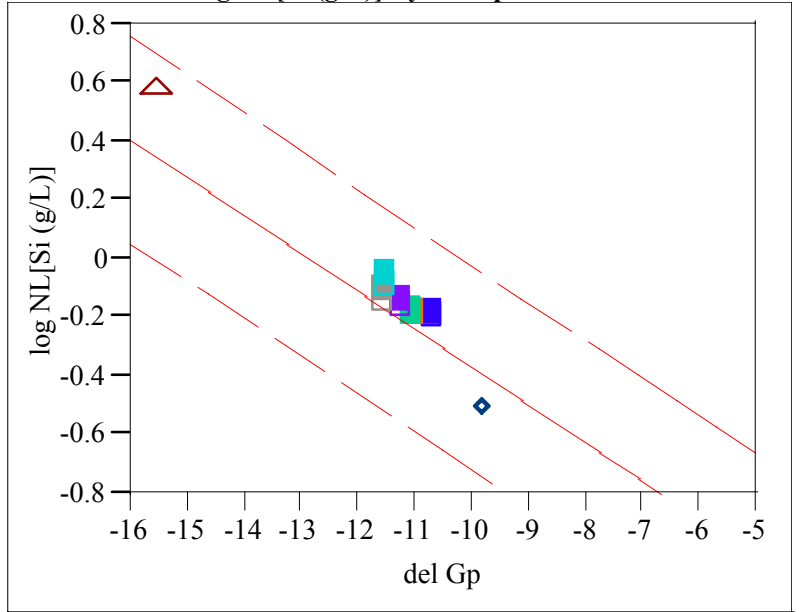


Exhibit F8. del $\mathbf{G p}\left(\Delta \mathbf{G}_{\mathrm{p}}\right)$ Predictions versus Common Logarithm Normalized Leachate $(\log \mathrm{NL}[]$.$) for \mathrm{B}, \mathrm{Li}, \mathrm{Na}$, and $\mathrm{Si}$ by Compositional View for VIS Glasses (continued)

\section{Targeted Data}
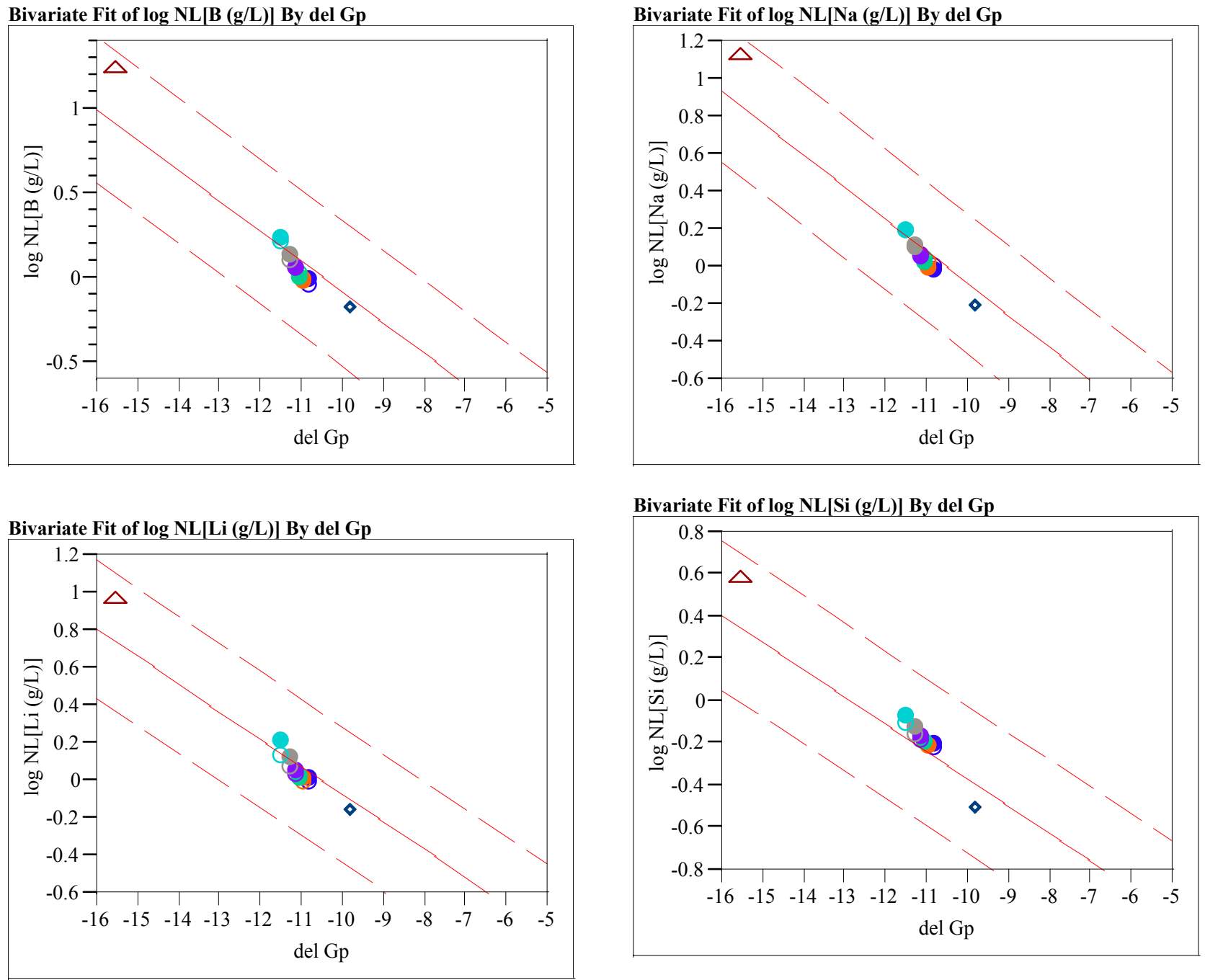